

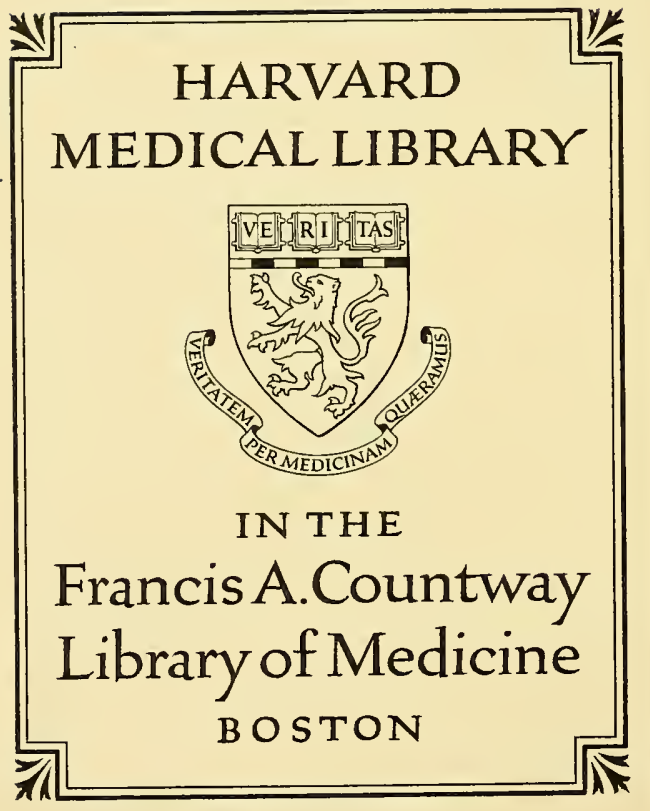




$$
{ }_{62}^{2}
$$



Digitized by the Internet Archive in 2010 with funding from

Open Knowledge Commons and Harvard Medical School

http://www.archive.org/details/experimentalmorpdave2 


thexisto. 


\section{ExPERIMENTAL MORPHOLOGY}

$\mathrm{BI}$

CHARlES BENEDiCT DAVENPORT, Ph.D.

INSTRECTOR IY ZOÖLOGY IN HARTARD CXINERSITY

\section{PART SECOND}

EFFECT OF CHEIICAL AND PHTSICAL AGENTS UPON GROWTH

X̃cus 琶ork

THE MACMILLAN COMPANY

LONDON: MACMILLAN \& CO, LTD.

1899

All rights reserved 
Copyright, 1899,

By THE MACMILLAN COMPANY. 


\section{PREFACE TO PART II}

Developiext consists of growth and differentiation, accompanied in the larger organisms by nuclear- and cell-division. The present Part deals with growth.

The importance of the study of growth cannot be orerestimated, and it is a cause for wonder that the treatment of the subject has been so much neglected by text-books. Indeed. it is a surprising fact that it has not been thoroughly and srstematically inrestigated. For, in last analysis, the maintenance of the human race depends upon that property which protoplasm among all substances alone displays of increasing itself for an indefinite time and to an indefinite amount. And the possibility of increasing the human race bejond limits that are not far off depends upon a better knowledge of the conditions of growth. The reader has only to consider that the world's supply of 2500 million bushels of wheat. 2000 million bushels of maize, 90 million tons of potatoes, and its untold millions of tons of beef, pork, and fish are reproduced each year by growth. The mineral matters of the soil are being washed out into the sea and are largely lost, but the capacity of growth under appropriate conditions is never lost; it redoubles as the amount of the growing substance is increased. The only thing. then, which limits growth is the limitations in the conditions of growth. What are these conditions? This is the important question to which attention has been directed in this Part.

Aside from this practical interest, the study of growth is important as bearing on the question of the dependence of rital activities, and especially derelopment, upon external conditions. 
and the possibility of the control of derelopment by appropriately altering those conditions. Growth phenomena show themselves, indeed, particularly susceptible to this control, and are consequently especially valuable for experimental study.

In the preparation of the Second Part, I have been put again under heavy obligations to my friend and colleague, Dr. G. H. PARKer, who has read most of the manuscript and made important suggestions. I am also indebted to Dr. H. E. SAwrEe for reading Chapter XI in the manuscript, and to my wife for much painstaking work on the manuscript and proofs and for compiling the index.

C. B. D.

Cautridge, Mass., Dec. 11, 1898. 


\title{
CONTENTS
}

\author{
CHAPTER X
}

PAGE

Introduction: ON Normal Growth . . . . . . 281

\section{CHAPTER II \\ Effect of Chemical Agexts vpox Growth}

$\S 1$. Effect of Chemical Agents upon the Rate of Growth . 293

1. The Materials of which Organisms are composed . . . . 291

a. Analysis of the Entire Organism . . . . . 296

b. Detailed Account of the Various Elements used as Food 304 Oxygen, 301; Hydrogen, 306; Carbon, 306 ; Nitrogen, 307 ; Phosphorns, 313 ; Arsenic, Antimony, and Bismuth, 314; Sulphur, 314; Chlorine, 316; Bromine, 316; Iodine, 317; Fluorine, 317 ; Lithium, 318; Sodium, 318; Potassium. 318; Rubidium and Cæsium, 320; Strontium, 321 ; Manganese, 321; Iron, 321 ; Magnesium, 323 ; Silicon, 324 ; Copper, 324.

2. The Organic Food used by Organisms in Growth . . . 324

a. Fungi . . . . . . . . . . . . . 324

b. Green Plants . . . . . . . . . . 326

c. Animals . . . . . . . . . . 327

Amœba, 32s; Amphibia, 329; Mammals, 330.

3. Growth as a Pesponse to Stimuli . . . . . . 331

a. Acceleration of Growth by Chemical Stimulants . . 331

Ђ. The Election of Organic Food . . . . . 333

§ 2. Effect of Chemical Agents upon the Direction of Growth - Chemotropism . . . . . . . . . . . 335

1. Chemotropism in the Tentacles of Insectirorous Plants . 335

2. Chemotropism of Roots . . . . . . . 336

3. Chemotropism of Pollen-tubes . . . . . . . . 337

4. Chemotropism of Hyphæ . . . . . . . 340

5. Chemotropism of Conjugation Tubes in Spirogyra . . 342

Literature 


\section{CHAPTER XII}

Tile EFfect of WATer Upon Growth

\$ 1. Effect of Water upon the Rate and Quantity of Growth PAGE

$\$ 2$. Effect of Water on the Direction of Growth-Hydrotropism . 355

1. Roots . . . . . . . . . . . 356

2. Rhizoids of Iligher Cryptogams . . . . . . . . 357

3. Stems . . . . . . . . . . . 358

4. Pollen-tubes . . . . . . . . . . . 358

Literature

5. Hyphæ of Fungi . . . . . . . . . . 358

\section{CHAPTER XIII}

Effect of the Density of the Medium upon Growth

$\S 1$. Effect of Density upon the Rate of Growth . . . . . . 362

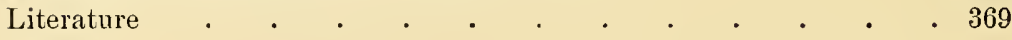

\section{CHAPTER XIV}

\section{Effect of Molar Agents upon Growth}

$\S$ 1. Effect of Molar Agents upon the Rate of Growth . . . . . 370

1. Contact . . . . . . . . . . 370

2. Rough Movements . . . . . . . . . . 370

3. Deformation . . . . . . . . . . . 372

4. Local Removal of Tissue . . . . . . . . . 375

§ 2. Effect of Contact upon the Direction of Growth - Thigmotropism 376

1. Twining Stems . . . . . . . . . 376

2. Tendrils . . . . . . . . . . . . 377

3. Roots . . . . . . . . . . . . . 380

4. Cryptogams . . . . . . . . . . . . 381

5. Animals . . . . . . . . . . . . 382

6. The Accumulation of Contact-stimulus and Acclimatization to it . . . . . . . . . . . 382

7. Explanation of Thigmotropism . . . . . . . 383

§ 3. Effect of Wounding upon the Direction of Growth - Traumatropism . . . . . . . . . . . 384

1. False Traumatropism . . . . . . . . . 384

2. True Traumatropism . . . . . . . . . 384

$\S 4$. Effect of Flowing Water upon the Direction of Growth - Rheotropism . . . . . . . . . . . 387

Summary of the Chapter . . . . . . . . . 388

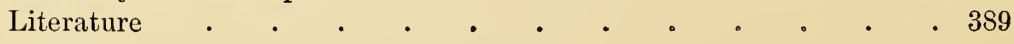




\section{CHAPTER XV}

\section{Effect of Gravity upon Growth}

§ 1. Effect of Gravity upon the Rate of Growth . . . . . 391

§ 2. The Effect of Gravity upon the Direction of Growth-Geotropism 391

1. False Geotropism . . . . . . . . 392

2. True Geotropism . . . . . . . . . . 392

a. Poots . . . . . . . . . . . . 392

b. Stems . . . . . . . . . . 397

c. Rhizoma. . . . . . . . . . 398

d. Cryptogams . . . . . . . . . 398

e. Animals . . . . . . . . . . 398

f. After-effect in Geotropism . . . . . . . 401

Summary . . . . . . . . . . . . 402

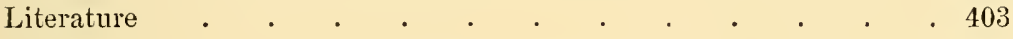

\section{CHAPTER XVI}

\section{Effect of Electricity upon Growth}

§ 1. Effect of Electricity upon the Rate of Growth . . . . . 405

$\S 2$. Effect of Electricity upon the Direction of Growth-Electro- 409 tropism . . . . . . . . . . . 409

1. False and True Electrotropism . . . . . . . 409

2. Electrotropism in Phanerogams . . . . . . 411

3. Electrotropism in Other Organisms . . . . . 412

4. Magnetropism . . . . . . . . . . 413

5. Explanation of Electrotropism and Summary . . . . 413

Literature . . . . . . . . . . . . 414

\section{CHAPTER XVII}

\section{EFfect of Light upon Growth}

§ 1. Effect of Light on the Rate of Growth . . . . . . . 416

1. Retarding Effect of Light . . . . . . . . . 416

2. Accelerating Effect of Light . . . . . . . . . 423

3. The Effective Rays . . . . . . . . . 427

a. The Effective Rays in the Retardation of Growth by Light 427

b. The Effective Rays in the Acceleration of Growth by Light 432

4. The Cause of the Effect of Light on the Rate of Growth . 436

§ 2. Effect of Light upon the Direction of Growth - Phototropism 437

1. Plants . . . . . . . . . 437

2. Animals . . . . . . . . . . . . . 442

a. Serpulidæ . . . . . . . . . 442

b. Hydroids . . . . . . . . . . 443 
PAGE

3. General Considerations . . . . . . . . 444

a. Persistence of Stimulation . . . . . . . 444

b. Acclimatization to Light . . . . . . 444

c. Mechanics of Phototropism . . . . . . . . 444

Literature . . . . . . . . . . . . 445

\section{CHAPTER XVIII}

\section{EFFect of Heat on Growti}

$\S 1$. Effect of Heat on the Rate of Growth . . . . . . 450

1. Plants . . . . . . . . . . . 450

2. Animals . . . . . . . . . . . . 457

3. Some General Phenomena accompanying Heat Effects . . 460

a. Latent Period . . . . . . . . . 460

b. Sudden Change of Temperature . . . . . 460

c. Cause of Acceleration of Growth by Heat . . . 461

$\S 2$. Effect of Heat on the Direction of Growth-Thernotropism . 463

1. Effect of Radiant Heat . . . . . . . . 463

2. Conducted Heat . . . . . . . . . . 464

3. Causes of Thermotropism . . . . . . . . 466

Summary of the Chapter . . . . . . . . . 467

Literature . . . . . . . . . . . . 467

\section{CHAPTER XIX}

\section{Effect of Complex Agents upon Growth, and General Conclusions}

$\S 1$. The Coöperation of Geotropism and Phototropism . . . 470

§ 2. Effect of Extent of Medium on Size . . . . . . . 473

$\S 3$. General Considerations relating to the Action upon Growth of

External Agents . . . . . . . . . 478

1. Modification of Rate of Growth . . . . . . 448

2. Modification of Direction of Growth - Tropism . . . 480

3. Adaptation in Tropisms . . . . . . . . 484

4. Critical Points in Tropism . . . . . . . 481

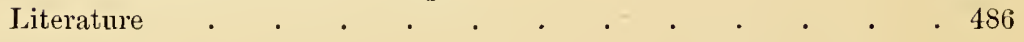

List of Tables in Parts I and II • • • • • • • . 489

Index to Parts I And II . . . . . . . . . 493 


\section{Part II}

\section{THE EFFECT OF CHEMICAL AND PHYSICAL AGENTS UPON GROWTH}

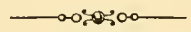

\section{CHAPTER X}

\section{INTRODUCTION: ON NORMAL GROIVTH}

OrGANIC growth is increase in volume.* It is not development; it is not differentiation; it is not increase in mass, although the latter may often serve as a convenient measure of growth.

In analyzing the processes of growth in organisms we must recognize at the outset that organisms are composed of living matter and formed substance, and that growth may therefore result from the increase in volume of either of these. The living matter, in turn, is composed of two principal substances : the plasma and the enchylema or cell sap; so growth may be due to the increase of either of these substances, - may result either from assimilation, or more strictly from the excess of

* Growth has been variously defined. Thus HuxLEx has ealled growth "increase in size," which is essentially the same as my definition. SAchs ('87, p. 404) defines growth as an increase in volume intimately bound up with change of form ("eine mit Gestaltveränderung innig verknüpfte Volumenzunahme"); and he illustrates the definition by the example of the growth of a sprout from its beginning to its full development. In this case two phenomena are distinguishable: first, increase in volume, and, second, the filling out of the details of form. As SAcris says, these phenomena taken together are generally denominated "development"; and it seems decidedly advantageous to retain this word with its usual signification, and to distinguish the two component processes by the terms growth and differentiation.

Pfeffer's ('81, p. 46) definition differs still more widely from the one proposed above. He defines growth as change in form in the protoplasmic body ("die gestaltliche Aenderung im Protoplasmakörper"); and he goes on to say that increments of volume and mass are not proper criteria of growth. Pfefrer illustrates this statement by the following example: A plant stem or a cell mem- 
the constructive over the excretory processes of the plasma, or from the taking in of water.*

Of the three factors involved in growth-increase of formed substance, of plasma, and of enchylema - the part played by the last seems to me to have been underestimated. Plant physiologists have been in the best position to acquire the facts.

brane can be permanently elongated by extension beyond the limits of elasticity without the volume necessarily increasing; - and he apparently means to include such an artificial deformation in his definition of growth. "And," he continues, "ninder certain circumstances a diminution of volume of a plant segment can indeed occur as a result of growth, when, for example, the elasticity of the wall is increased by growth and water is pressed from the cell until equilibrium is restored." It may be doubted, however, if Pfeffer would say that in this case the cell, as a whole, had grown; but if he would, then his definition is a wide departure from ordinary usage.

Also, Vines ('86, p. 291) offers a definition, which is intermediate between that of SAchs and that of PFeffer. "By growth," he says, "we mean permanent change of form, accompanied usually by increase in bulk." But then he goes on to say, "Nor does this increase even of the organized structures of an organ, that is of the protoplasm and the cell wall, necessarily imply that it is growing. Thus, an increase of the cell wall may take place without any appreciable enlargement of the cell, as, for instance, when a cell wall thickens." But since the thickening is a "permanent change of form," it should be considered by the author a growth process were not increase in size of the cell after all, in the author's mind, the most important criterion of its growth. Finally, Frank ('92, p. 355) finds no other criterion for growth than an increase in volume (dependent, however, upon the increase of a particular substance). Thus, with these different plant physiologists, we see the word growth bearing the ideas of increase of volume and clifferentiation, then of differentiation alone, and, finally, of increase of volume alone.

* Various analyses of the process of growth have been made by different authors. Let us look at a few of these opinions. Says Huxuey ('77, p. 2), "growth is the result of a process of molecular intussusception." According to N. J. C. Müller ('80, p. 100), " all phenomena of growth depend, in last analysis, upon this, that the molecule of the solicl substance is introdnced into the region of growth." Frank ('92, p. 355) understands by growth that increase of volume which consists of the apposition or intussusception of new solid molecules of similar matter ("welche auf der An- oder Einlagerung neuer fester Molekule gleichartigen Stoffes beruhen"). According to VERworN ('95, p. 475), growth is due to the excess of assimilation over disassimilation. These definitions include what I regard as only half the process of growth.

On the other hand, Driescr ('94, p. 37) distinguishes two kinds of cell growth: (1) passive growth, due to imbibition of water, and (2) active growth, resulting from assimilation. This classification agrees with the one $I$ have proposed, but I think the term passive growth very inapt, since the imbibition of water is as truly an active process as any other vital activity. 
They have recognized in the tip of the plant three growth regions. At the extreme tip of the stem (or radicle) is the region of rapid cell division but comparatively slow growth;

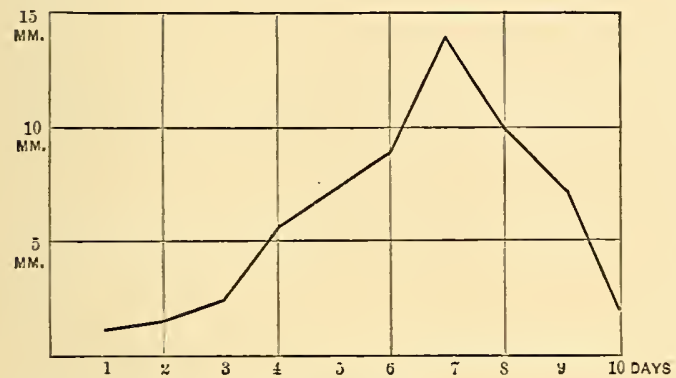

Fig. 75. - Curre of dails growth in length of a dise, originally $1 \mathrm{~mm}$. long, and taken immediately behind the regetation point of a radicle of Phaseolus. It comes to occupy in successire days the three zones referred to in the text. From SAcHs, Lectures on Plant Physiology.

next below is the zone exhibiting the Grand Period of growth; and still below is the zone of histological differentiation (Fig. 75). In the first zone growth of plasma is occurring; in the second zone growth of the enchylema is chiefly taking place; in the third zone there is growth of formed substance. The immense preponderance of the growth of the second period (at 7 days) is an index to the preponderating influence in growth of the imbibition of water.

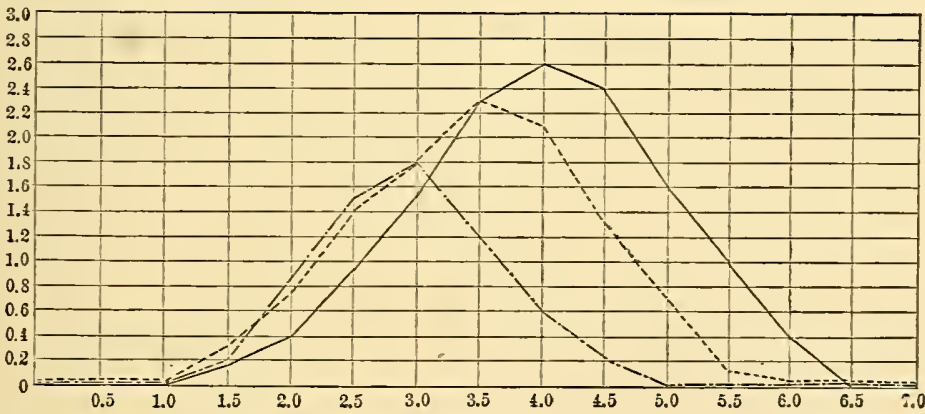

FIG. 76. - Curre representing the intensity of growth of roots of Pisum sativum, -; Ticia satira, .........-; and Lens esculenta, - . - . - , the time being assumed to be constant. The length of the abscissæ in the direction from left to right corresponds to the distance, in millimeters, of the marked spaces on the root from the root apex. The ordinates correspond to the amount of growth, in millimeters, of the corresponding piece of the root after 20 hours. From CIESIELSKI ('i2.)

That which occurs with one and the same piece of the stem on successive days takes place simultaneously at the different zones of the growing organ. Thus in the radicle (Fig. 76 ) 
we find during a period of 20 lours little growth occurring at the root tip, a maximum of growth at 3 or 4 millimeters from the tip, and further up less growth, until a zone of almost no growth is reached.

An analysis of the substance of the stem at different levels below the tip reveals the same thing - a sudden increase in the

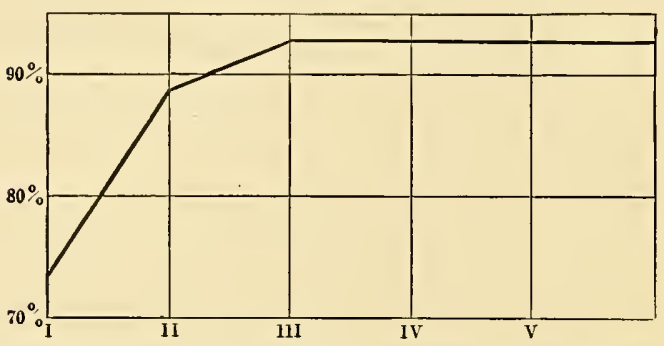

Fig. 77. - Curve showing the percentage of water in successive internodes of hothouse plants of Heterocentron roseum Hook. et Arm., about 4 decimeters high. The ordinates indicate the percentage of water at each internode from the terminal bud (I) to the fifth (VI). (From Kraus, '79.) amount of water from $73 \%$ at the tip to $88 \%$ at the first internode (II), reaching a maximum at $93 \%$ in the second internode (III), then falling slightly (92.7) to the fifth internode (VI, Fig. 77). The experiments and observations upon which these conclusions rest thus agree in assigning the chief rôle to water in the growth of plants.

While the fact that water constitutes a large proportion of the growing animal was made known by the classical researches of Baudrimont and Martin Saint-Ange ('51), the importance of the part which it plays in the growth of animals seems first to have been appreciated by $\operatorname{LoEB}(92$, p. 42), who showed how in the withdrawal of water by plasmolytic methods growth was interfered with. Later I made a series of determinations of the relative part played by water and dry substance in the growth of an animal (tadpole). Eggs and embryos at various ages were weighed after removal of superficial water. Then they were kept in a desiccator from which air had been pumped and which contained a layer of sulphuric acid to absorb moisture. After repeated weighings a condition was found in which the drying mass lost no more water (constant weight). The total diminution in weight indicated the mass or volume of free water contained in the organism at the beginning of the experiment. Numerous weighings were 
made during two seasons upon Amblystoma, toads, and frogs. All series showed the same thing; the most complete series is that given in the following table:-

TABLE XXII

ЕзвRTos of Frogs. 1895*

\begin{tabular}{|c|c|c|c|c|c|}
\hline Date. & $\begin{array}{l}\text { DaYs after } \\
\text { Hatchivg. }\end{array}$ & $\begin{array}{c}\text { Average } \\
\text { Weigut, in Mg. }\end{array}$ & $\begin{array}{c}\text { Weight of Dry } \\
\text { Substance, } \\
\text { IN MG. }\end{array}$ & $\begin{array}{c}\text { Weigit of } \\
\text { Water IN MG. }\end{array}$ & $\begin{array}{c}\% \text { OF } \\
\text { WATER. }\end{array}$ \\
\hline May 2 & 1 & 1.83 & .80 & 1.03 & 56 \\
\hline $\begin{array}{ll}\text { 6 } 3\end{array}$ & 2 & 2.00 & .83 & 1.17 & 59 \\
\hline " & 5 & 3.43 & .80 & 2.63 & 77 \\
\hline 6 & 7 & 5.05 & .54 & 4.51 & 89 \\
\hline "6 10 & 9 & 10.40 & .72 & 9.68 & 93 \\
\hline " 15 & 14 & 23.52 & 1.16 & 22.36 & 96 \\
\hline June 10 & 41 & 101.0 & 9.9 & 91.1 & 90 \\
\hline July 23 & 84 & 1989.9 & 247.9 & 1742.0 & 88 \\
\hline
\end{tabular}

These results are graphically represented in Fig. 78. The curve and table show that, exactly as in plants, there is a

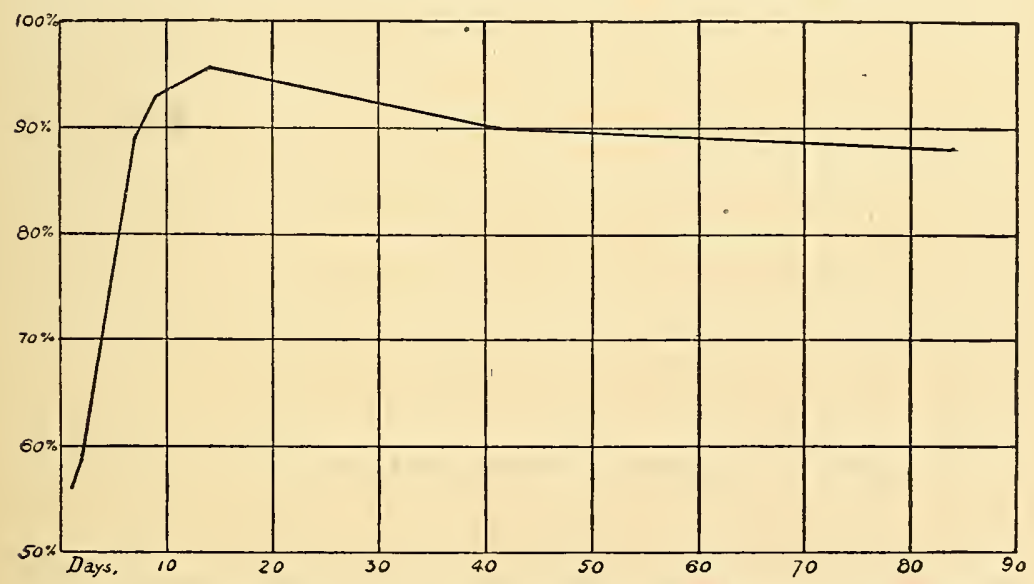

FIG. 78. - Graphic representation of last column of Table, showing percentage of water in frog embryos from 1 to 84 days after hatching. Compare with Fig. 77.

period of slow growth accompanied by abundant cell division - the earliest stages of the egg. Then follows, after the first

* Compare with the less complete table of Baddrimont and Martin SaintANGe, '51, p. 532. 
few hours, a period of rapid growth due almost exclusively to imbibed water, during which the percentage of water rises from 56 to 96 ; lastly comes the period of histological differentiation and deposition of formed substance, during which the amount of dry substance increases enormously, so that the percentage of water falls to 88 and below. But the growth is due chiefly to imbibed water.

The foregoing facts thus unite in sustaining the conclusion that at the period of most rapid growth of organisms growth is effected by water more than by assimilation.

In later development the proportion of water slowly falls. This fact is well brought out in the following tables :-

TABLE XXIII

Showing the Percentage of Water in Chick Eubryos at Various Stages UP to Hatching, from Potss, 79

\begin{tabular}{c|c|c}
\hline Hovrs of Brooding. & Absoldte Weight in Gram. & \% Water. \\
\cline { 2 - 3 } 48 & 0.06 & 83 \\
54 & 0.20 & 90 \\
58 & 0.33 & 88 \\
91 & 1.20 & 83 \\
96 & 1.30 & 68 \\
124 & 2.03 & 69 \\
264 & 6.72 & 59 \\
\hline
\end{tabular}

TABLE XXIV

Showing the Percentage of Water in the Human Embryo at Various Stages up to Birth, from Fehling, ' 77

\begin{tabular}{c|c|c}
\hline AGe IN WeEks. & Absolute Weight in Gram. & \% Witer. \\
\hline 6 & 0.975 & 97.5 \\
17 & 36.5 & 91.8 \\
22 & 100.0 & 92.0 \\
24 & 242.0 & 89.9 \\
26 & 569.0 & 86.4 \\
30 & 924.0 & 83.7 \\
35 & 928.0 & 82.9 \\
39 & 1640.0 & 74.2 \\
\hline
\end{tabular}


These results indicate that during later development growth is largely effected by excessive assimilation or by storing up formed substance.

From another standpoint we can recognize two kinds of growth: one a transitory growth, after which the enlarged organ may return again to its former size, and the other a permanent or developmental growth, which is a persisting enlargement, and plays an important part in development. As an example of transitory growth may be cited the case of the Sensitive Plant, whose leaflets when touched turn upiwards as a result of the growth of cells on the convex side; but this enlargement is only temporary - it is transitory growth. This phenomenon is indeed usually not included in the idea of growth; yet it is well-nigh impossible to draw a sharp line of distinction between it and permanent growth. For example, when a tendril of the Passion Flower is touched it may curre as a result of growth of the cells on the convex side, and this curvature may later become obliterated, as in the case of the Sensitive Plant; but the longer the contact is continued the more the cells enlarge, and the more their walls become permanently modified. Thus the condition of temporary growth shades insensibly into that of permanent growth. - So far as possible we shall consider in this book only developmental growth.

Still another classification may be made of the phenomena of growth. We may distinguish between diffused and localized growth. In diffused growth the entire individual or many of its parts are involved. In localized growth the process is confined to a limited region. Thus in the early development of the frog diffused growth occurs, while in the formation of the appendages we have an example of localized growth. Since localized growth is an important factor in differentiation, many of the data concerning this phenomenon will be first considered in the Part dealing with Differentiation.

Normal growth may or may not be accompanied by cell-division. But usually cell-division occurs sooner or later in the growing mass. The act of cell-division seems to retard the process of growth. This conclusion follows from some experiments of WARD ('95, p. 300) on the growth of bacteria, which 
are summarized in the eurve, Fig. 79. This shows how the growth in length of the bacterial rods is delayed at intervals

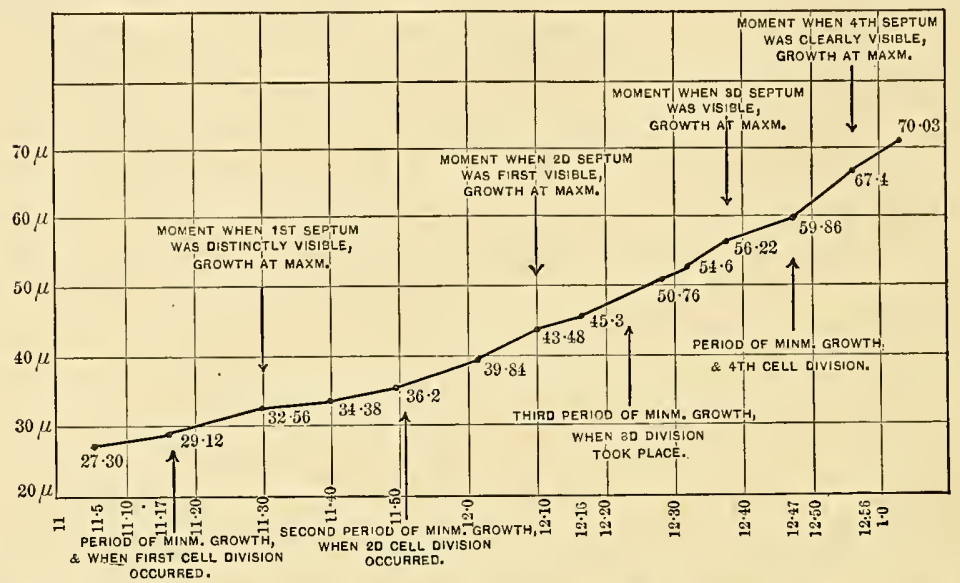

Fig. 79. - Curve of growth of a bit of a filament of Bacillus ramosus, $27.30 \mu$ long at the beginning and $70.88 \mu$ at the end of the period of observation. The curve shows certain periods of diminished growth (indicated by the arrows below the curve), which correspond to cell-division. From WARD ('95, p. 300).

by the nuclear divisions and the accompanying formation of transverse septa.**

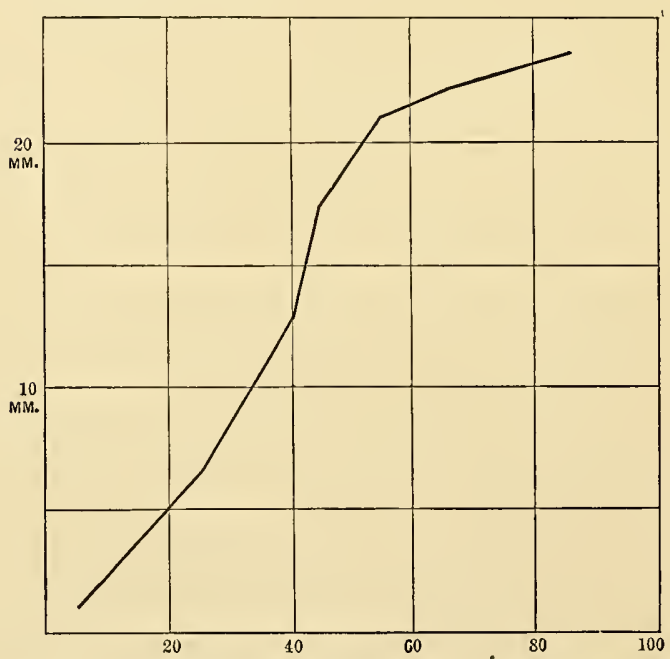

Fig. 80. - Curve of length of shell of Lymnæa stagnalis at intervals from latching up to 85 days. From SeMper, Animal Life, p. 163.
The course of normal growth may now be studied in

* Attention may here be called to a phenomenon which has repeatedly been observed when a single growing mammal has been weighed at regular intervals. This is a sort of alternation of periods of unusually rapid growth with periods of diminished growth, the interval being a day or two. There is an irregularity in the length of these periods. See SAINTLovp, '93 ; compare also Mrnot, '91, Table XIV. 
the case of certain selected, typical organisms. This may be most quickly done by the use of curves whose abscissæ represent time intervals and whose ordinates represent size or weight. Figures 80,81 , and 82 are such curves. In all cases excepting that of guinea pig (in which the curve represents the growth of only a comparatively late developmental period, namely, from birth onward) the curves exhibit one characteristic shape.

The absolute increments are not, however, shown directly by these curves. To obtain them one must transform the curves into others in which the successive ordinates shall represent the absolute increment of weight over the last preceding. Under these circumstances the absolute increments rapidly reach a maximum from which they decline to zero.*

Why does the growth decline to zero? The theory has been suggested $\dagger$ that there is a "certain impulse given at the time of impregnation which gradually fades out, so that from the beginning of the new growth there occurs a diminution in the rate of growth." The facts of

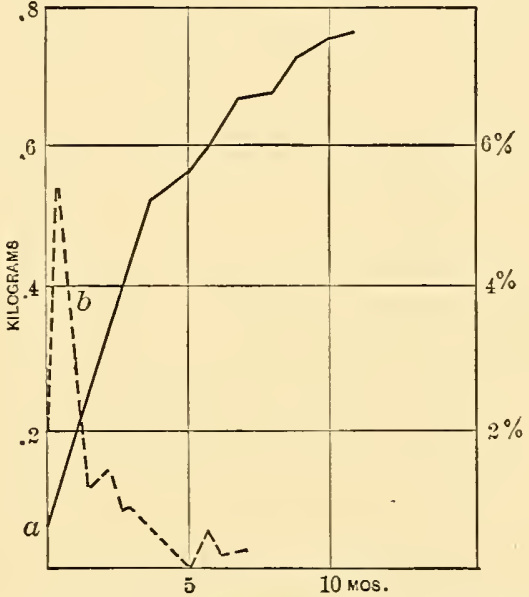

Fig. 81. - The continuous line (a) represents the weights in fractions of a kilogramme attained by guinea pigs from birth until 12 months old. The broken line $(b)$ represents the daily percentage increments (\%'s at the right) of the same guinea pigs up to 7 months. After Mixot ('y1).

* Another method of representing curves of growth has been proposed by Professor Мiмoт ('91, p. 148), who argues that for a given period the rate of growth should be expressed as the fraction of weight added during that period; for, he says, "the increase in weight depends on two factors: first, upon the amount of body substance, or, in other words, of growing material present at a given time ; second, upon the rapidity with which that amount increases itself." Such a curve of percentage daily increments is given for the guinea pig in Fig. 81. Since, however, the greater part of the "body substance" at its period of greatest growth is not "growing material," as assumed, but water, the peculiar value of the curve of percentage increments is doubtful.

† Ву Мкот, '91, p. 151. 
growth in the tip of the plant do not, however, support this theory, for the protoplasm at this point may go on growing

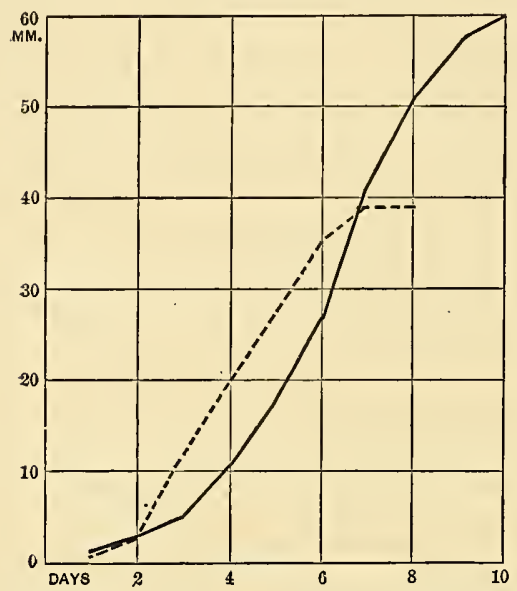

Fig. 82. - Curves of growth of Phaseolus - multiflorus (continuous line) and Vicia faba (broken line). The ordinates represent actual lengths attained on the respective days by a bit of stem originally $1 \mathrm{~mm}$. long. After SACHs, Lect. ures on Plant Physiology. for centuries, as we see in the case of trees. Some of the protoplasm at the tip is, however, constantly falling back to form part of the stalk: this part soon ceases to grow, undergoing histological differentiation. The reason why the animal ceases at length to grow is the same as the reason why the differentiated tissue below the tip of the epicotyl ceases to grow - not because there is a necessary limit to growth force at a certain distance from impregnation, but because it is in the nature of the species that the individual should cease to grow at this point. The indefinite growth of this part, the limited growth of that, are as much group characters as any structural quality.

To recapitulate briefly : Growth is increase in size, and may result from increment of either the formed substance through secretion, the plasma through assimilation, or the enchylema through imbibition. This increment may be either transitory or permanent; the latter class chiefly concerns us here. Growth may be either diffused throughout the entire organism, or local, forming a factor of differentiation. In normal growth the increase is at first slow, then rapidly increases to a maximum, and, finally, in most animals, diminishes to zero. This final cessation is a special quality of certain organisms, to be explained like structural qualities, on special grounds. 


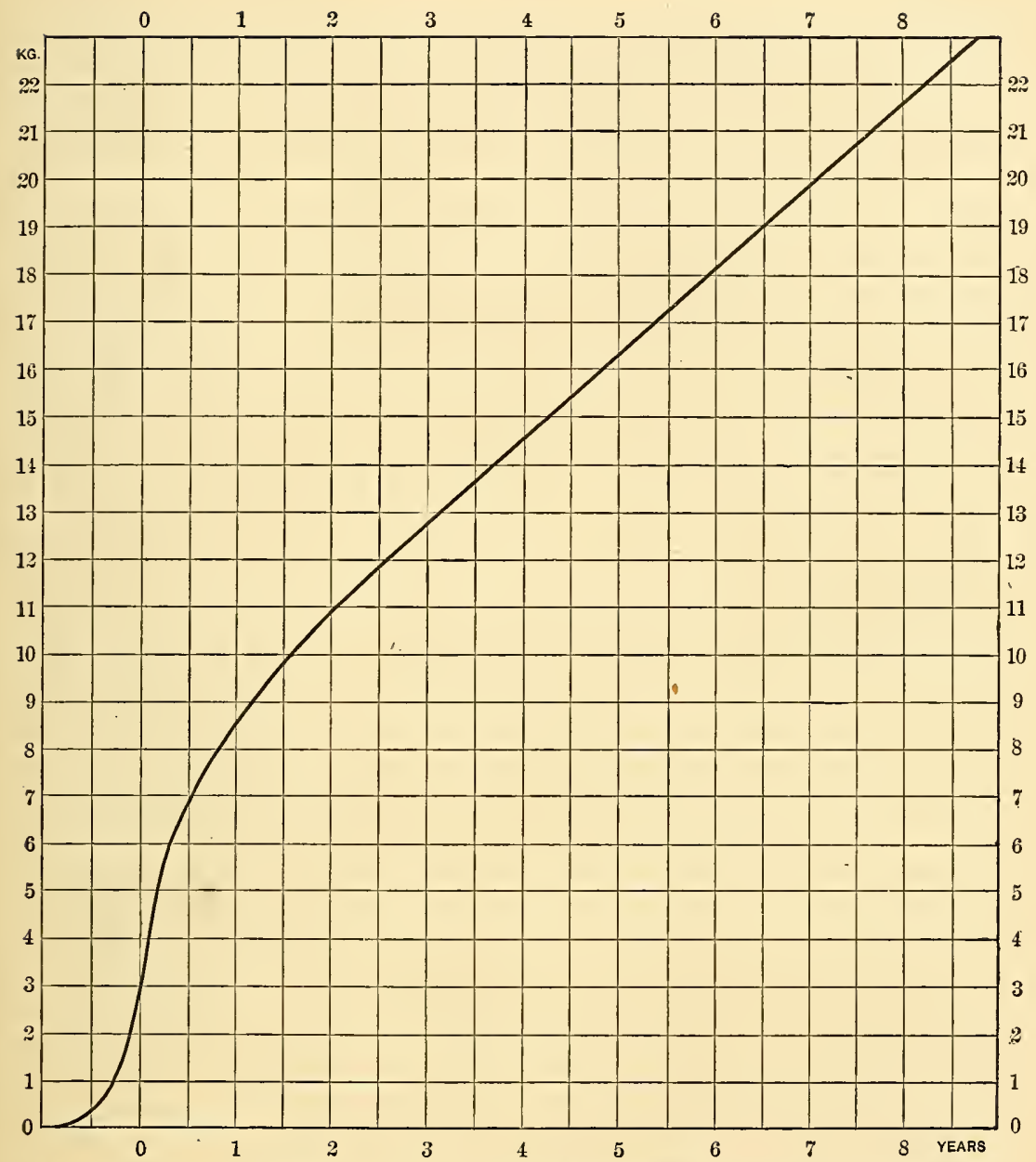

Fig. 83. - Curve of growth of man. The ordinates represent weight in kilogrammes.

The prenatal part of the curve is constructed from the data of FeHLiNg ('77); the postnatal part from QueTeLet ('71) for the male. The curve of the first twelve months of postnatal life is adapted from GALTON ('84).

\section{LITERATURE}

Baudrimont, A., and G. T. Martin Saint-Ange,'51. Recherches anatomiques et physiologiques sur le développement du foetus et en particulier sur l'évolution embryonnaire des oiseaux et des batrachiens. Mém. presentés par divers savants à l'Acad. des Sci. de l'Inst. Nat. de France. XI, 469-692. 18 pls. 
Driescu, H. '94. Analytische Theorie der organischen Entwicklung. Leipzig. Engelmanu, 185 pp. 1894.

Feirlng, H. '77. Beiträge zur Pliysiologie der placentaren Stoffverkehrs. Arch. f. Gynäkologie. XI, 523-557.

Frank, A. B. '92. Lehrbuch der Botanik nach dem gegenwärtigen Stand der Wissenschaft bearbeitet. I. Band. Leipzig. 1892.

Galton, F. '84. Life History Album. 172 pp. London. 1884.

Huxley, T. H. '77. A Manual of the Anatomy of Invertebrated Animals. 698 pp. London. 1877.

Kraus, G. '79. Ueber die Wasservertheilung in der Pflanze. Festschr. z. Feier des Hundertjahrigen Bestehens d. Naturf. Ges. in Halle. pp. 187-257.

LoeB, J. '92. Untersuchungen zur physiologischen Morphologie der Thiere. II. Organbildung und Wachsthum. 82 pp. 2 Taf. Würzburg. 1892. Мгот, C. S. '91. Senescence and Rejuvenation. Jour. of Physiol. XII, 97-153. Plates 2-4.

Müller, .N. J. C. '80. Handbuch der allgemeinen Botanik. I. Theil. Heidelberg. 1880.

Pfeffer, W.' 81 . Pflanzenphysiologie. Engelmann. Leipzig. 2 Bde. $383+474 \mathrm{pp}$.

PoLt, R. '79. Untersuchungen über die chemischen Veränderungen im Hühnerei während der Bebrütung. Landwirth. Versuchs-Stat. XXIII, 203-247.

Quetelet, A. '71. Anthropométrie ou mesure des différentes facultés de l'homme. $479 \mathrm{pp} .2 \mathrm{pls}$. Bruxelles and Paris. 1871.

SACHs, J. '87. Vorlesungen über Pflanzenphysiologie. Leipzig. Engelmann. 884 pp. 1887.

Saint-Loup, R. '93. Sur la vitesse de croissance chez les Souris. Bull. Soc. Zool. de France. XVIII, 242-245.

Verworn, M. '95. Allgemeine Physiologie. 584 pp. Jena: Fischer. 1895.

Vines, S. H. '86. Lectures on the Physiology of Plants. Cambridge [Eng.] Univ. Press. 710 pp. 1886.

WARD, H. M. '95. (See Chapter XVII, Literature.) 


\section{CHAPTER XI}

EFFECT OF CHEMICAL AGENTS UPON GROIVTH

We shall consider this subject under two heads : (1) Effect upon the rate of growth, and (2) Effect upon the direction of growth.

\section{§1. Effect of Chemical Agents upox the Rate of Growth}

Organic growth, occurring in a material composed of water, plasma, and formed substance, consists in the increment of each of these components. The means and results of varying the quantity of water in the organism will be discussed in the next chapter; here we are to consider the results of assimilation, including the production of formed substance. The scope of our work may be more precisely defined as the answer to the question, What rôle do the various chemical substances (excluding water) play in the metabolic changes involved in growth?

There are two rôles played by chemical substances in the body; and, accordingly, we may distinguish two kinds of chemical agents having diverse effects upon growth. These agents - foods, in the widest sense of the word - must supply the material - the atoms - from which the molecules of the plasma, or of its formed substance, are made up; and, secondly, they must supply energy for metabolism. Foods, then, yield to the organisms matter and motion; they are hylogenic (plastic) and thermogenic (respiratory).

These two offices of chemical agents in growth are only in certain cases exerted by distinct kinds of food. In the case of animals, sodium chloride and iron compounds are examples of wholly plastic foods, while the free oxygen taken into the body is chiefly thermogenic. In the case of the free oxygen, however, it is quite probable that it is sometimes used in the construction of the molecule of active albumen which, according 
to Loww, constitutes the essential living substance. For example, oxygen performs this office in Loew's ('96, p. 39) hypothesis of the formation of albumen in plants from the nitrogenous products which result from the action of an enzyme upon the reserve proteids, i.e. leucine. Thus

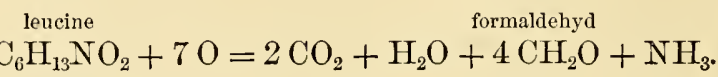

$$
\begin{aligned}
& \text { formaldehyd asparagin } \\
& 4 \mathrm{CH}_{2} \mathrm{O}+2 \mathrm{NH}_{3}+\mathrm{O}_{2}=\mathrm{C}_{4} \mathrm{H}_{3} \mathrm{~N}_{2} \mathrm{O}_{3}+3 \mathrm{H}_{2} \mathrm{O} \text {. }
\end{aligned}
$$

Now since, as Loww makes probable, asparagin is a stage in the production of albumen, the free oxygen molecule may be essential to the synthesis of the living substance.

The facts indicate that the plastic and thermogenic functions of foods are inextricably intermingled - that both are exhibited in the mutations of the living substance as well as in the respiratory processes. Thus, on the one hand, assimilation is accompanied not only by endothermic (energy-storing) but also by exothermic (energy-releasing) processes; while, on the other hand, the partial oxidation of the food proteids may be a necessary step towards assimilation. It is because the net result is the storing or the release of energy that we may speak of any complex of processes as enthodermic or exothermic, and certain foods as plastic or thermogenic.

The source of energy in organisms is not, however, solely food. Energy may likewise be derived directly from energy in the environment. This source is of greatest importance in the case of chlorophyllaceous organisms, but it is probably not of importance for them alone. For the heat and light of the environment aid, as we have seen (pp. 166-171, 222-225), various metabolic processes in all kinds of protoplasm.

1. The Materials of . which Organisms are Composed.-To determine the sorts of materials which plastic food must supply to the body, it will be instructive to consider the proportional composition of the body out of water and dry substance, both organic and inorganic. Such data, gathered from various animals and plants, are given in the following table :- 


\section{TABLE XXV}

Axmals

\begin{tabular}{|c|c|c|c|c|c|c|}
\hline SPECIES. & $20 \frac{2}{2}$ & 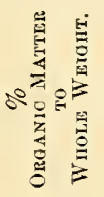 & 20 & 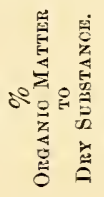 & 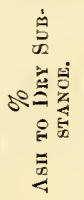 & Aбthority. \\
\hline Sponges, average .... & 79.4 & 11.0 & 9.7 & 54.1 & 45.9 & KRUKENBERG, '\$O \\
\hline $\begin{array}{c}\text { Medusa: } \\
\text { Rhizostoma cuvieri... }\end{array}$ & 95.4 & 1.6 & 3.0 & 34.8 & 65.2 & $=66$ \\
\hline $\begin{array}{l}\text { Actiniaria: } \\
\text { Anthea cereus. . }\end{array}$ & 87.6 & 10.7 & 1.6 & 87.0 & 13.0 & 66 \\
\hline Actinia mesembryanth. & 83.0 & 15.4 & 1.7 & 90.0 & 10.0 & "6 \\
\hline Sagartia troglody & 76.8 & 20.9 & 2.3 & 81.1 & 18.9 & "6 \\
\hline Cerianthus membran. . & 87.7 & 11.6 & 1.7 & 87.2 & 12.8 & "6 \\
\hline Alcyonium palmatum & 84.3 & 10.8 & 4.9 & 68.8 & 31.2 & "6 \\
\hline $\begin{array}{c}\text { Asteroidea: } \\
\text { Astercanthion glacialis. }\end{array}$ & 82.3 & 14.1 & 3.6 & 79.6 & 20.4 & 66 \\
\hline $\begin{array}{l}\text { Annelida: } \\
\text { Lumbricus complanatus }\end{array}$ & 87.8 & 9.7 & 2.4 & 80.2 & 19.8 & ، \\
\hline $\begin{array}{r}\mathrm{Cr} \imath \\
\text { Oniscus } \mathrm{m}\end{array}$ & 68.1 & 21.2 & 10.6 & 66.6 & 33.4 & BEZOLD, ' 57 \\
\hline Squilla mar & 72.0 & 22.1 & 5.9 & 78.9 & 21.1 & KRUKENbERG, 'so \\
\hline Astacus fluviatilus . . . & 74.1 & 16.8 & 9.1 & 64.9 & 35.1 & BEZOLD, ' 57 \\
\hline $\begin{array}{r}\text { Mol } \\
\text { s tuber }\end{array}$ & 88.4 & 9.0 & 2.6 & 77.6 & 22.4 & KRUKENBERG, ' 80 \\
\hline Do & 86.5 & 12 & 1.1 & 91.9 & 8.1 & 66 \\
\hline & 86.8 & 10.1 & 3.1 & 76.5 & 23.5 & BEZOLD, '5 7 \\
\hline Limax ma & 82.1 & 16.4 & 1.5 & 91.6 & 8.4 & "6 \\
\hline$\underset{\text { (without shell) }}{\text { Ostrea }}$. $\ldots$. & 88.3 & 10.8 & 0.9 & 92.3 & 7.7 & \\
\hline $\begin{array}{l}\text { Tunicata: } \\
\text { Botryllus..... }\end{array}$ & 93.6 & 3.1 & 3.3 & 48.4 & 51.6 & KRTKENBERG, ' $\$ 0$ \\
\hline $\begin{array}{r}\text { Vert } \\
\text { Cyprinus a }\end{array}$ & 77.8 & 17.6 & 4.6 & 79.1 & 20.9 & BEZOLD, ${ }^{\prime} 5 \pi$ \\
\hline Trito & 80.2 & 16.1 & 3.7 & 81.1 & 18.9 & "6 \\
\hline Triton cristatus . & 79.6 & 17.0 & 3.4 & 82.9 & 17.1 & ، \\
\hline Bombinator igneus . . . & 77.3 & 19.4 & 3.3 & 85.2 & 14.8 & "6 \\
\hline Bufo cinereus . . . . . & 79.2 & 14.8 & 6.0 & 71.1 & 28.9 & ، \\
\hline Rana esculenta & 82.7 & 14.2 & 3.0 & 82.2 & 17.8 & “6 \\
\hline Angius fragilis & 55.0 & 32.1 & 12.9 & 71.5 & 28.5 & “ \\
\hline Lacerta viridis. . & 71.4 & 23.2 & 5.4 & 81.3 & 18.7 & " \\
\hline Sparrow .... & 67.0 & 27.8 & 5.2 & 84.3 & 15.7 & "6 \\
\hline Bat... & 67.5 & 27.4 & 5.0 & 85.2 & 14.8 & ، \\
\hline Mouse & 70.8 & 25.7 & 3.5 & 88.0 & 12.0 & "6 \\
\hline Man .. & 65.7 & 29.6 & 4.7 & 86.3 & 13.7 & FolkMaNa, '74 \\
\hline
\end{tabular}


Plants

\begin{tabular}{ll|c|c|c|c|c|c}
\hline Oats, in blossom . . . & 77.0 & 6.4 & 16.6 & 27.8 & 72.2 & WoLF, '65 \\
Wheat, in blossom ... & 69.0 & 9.3 & 21.7 & 30.0 & 70.0 & "6 \\
Pea vines, green . . . & 81.5 & 4.8 & 13.7 & 26.0 & 74.0 & "6 \\
\hline
\end{tabular}

a. Analysis of the Entire Organism. - We are now ready to consider the atomic composition of the dry substance of organisms. VolKunan ('74) has contributed data on this subject in the case of man. Thus the dry substance gives :-

$$
\begin{array}{ccccc}
\mathrm{C} & \mathrm{O} & \mathrm{I} & \mathrm{N} & \mathrm{AsH} \\
52.9 \% & 18.5 \% & 7.7 \% & 7.4 \% & 13.4 \%
\end{array}
$$

In the case of a plant (stems and leaves of dry clover) we have, according to JoHnson : -

$$
\begin{array}{ccccccc}
\mathrm{C} & \mathrm{O} & \mathrm{H} & \mathrm{N} & \mathrm{S} & \mathrm{P} & \text { REMaINING ABH } \\
47.4 \% & 37.8 \% & 5.0 \% & 2.1 \% & 0.12 \% & 0.30 \% & 2.0 \%
\end{array}
$$

These two determinations, fairly typical of the higher plants and the higher animals respectively, run nearly parallel. 'The greatest difference is shown by the nitrogen, which is more than three times as abundant in animals as in plants. Oxygen, on the other hand, is more abundant in plants.

The ash, in turn, must be further analyzed. The following table gives the percentage composition of the ash of various

\begin{tabular}{|c|c|c|c|}
\hline A Nmal. & New-born Dog. & Menhaden (Fish). & Oat Plant. \\
\hline AUthoRItT. & BUNGE, 'S9. & Соoк, '68, p. 498. & AVEndt (Vines, ' 86, p. 129). \\
\hline $\mathrm{CaO}$ & 29.5 & 40.0 & 12.1 \\
\hline $\mathrm{P}_{2} \mathrm{O}_{5}$ & 39.4 & 35.8 & 8.8 \\
\hline $\mathrm{K}_{2} \mathrm{O}$ & 11.4 & 7.1 & 45.9 \\
\hline $\mathrm{Cl}$ & 8.4 & 3.1 & 6.1 \\
\hline $\mathrm{Na}_{2} \mathrm{O}$ & 10.6 & 4.7 & 2.32 \\
\hline $\mathrm{MgO}$ & 1.82 & 3.1 & 4.12 \\
\hline $\mathrm{Fe}_{2} \mathrm{O}_{3}$ & 0.72 & {$[-$} & 0.54 \\
\hline $\mathrm{SiO}_{2}$ & - & 6.1 & 17.2 \\
\hline $\mathrm{SO}_{3}$ & $\longrightarrow$ & $\longrightarrow$ & 2.86 \\
\hline
\end{tabular}
organisms :-

TABLE XXVI 
It would be valuable to know the relative number of atoms of each of the metalloids and metals named in the preceding table. This may be determined in the following way: Find the proportion by weight of each metallic radical (excluding the oxygen) in the entire ash and divide this percentage by the molecular weight of the metal. The rarying weights of the elements are thus eliminated, and a set of numbers which indicate relative abundance of atoms is obtained. We multiply these small fractions by 1000 for convenience. The results are as follows :-

TABLE XXVII

\begin{tabular}{|c|c|c|c|}
\hline & NEW-воRx Dog. & Menhadex (FIsh). & Oat Plajt. \\
\hline $\mathrm{Ca}$ & 528 & .715 & 216 \\
\hline $\mathrm{P}$ & 5็อั & 506 & 124 \\
\hline $\mathrm{K}$ & 243 & 151 & 974 \\
\hline $\mathrm{Cl}$ & 24 & 174 & 173 \\
\hline $\mathrm{Na}$ & 343 & 150 & 60 \\
\hline $\mathrm{Mg}$ & 45 & $\pi$ & 114 \\
\hline $\mathrm{Fe}$ & 9 & 一 & 6 \\
\hline $\mathrm{Si}$ & 一 & 101 & 287 \\
\hline $\mathrm{S}$ & 一 & - & 36 \\
\hline
\end{tabular}

These examples may suffice to show how diverse is the composition of different organisms and how diverse therefore must be their requirements in the way of food to build up the adult body. The examples serve also to indicate what are the important elements for organisms. They appear to be the same for animals and plants, and are :-

$\begin{array}{llll}\text { *Carbon } & \text { *Calcium } & \text { Sodium } & * \text { Sulphur } \\ \text { *Oxygen } & \text { *Potassium } & \text { Chlorine } & \text { Silicon } \\ \text { *Hydrogen } & \text { *Phosphorus } & \text { *Nagnesium } & \text { *Iron } \\ \text { *Nitrogen } & & & \end{array}$

While this list does not pretend to exhaust the elements found in organisms, it contains those which are usually present.

In the organism the atoms just named are, of course, found in combination. The carbon, oxygen, hydrogen, and nitrogen are contained in the organic matter of the organism - the

* Those elements which are starred (*) are essential to all organisms. 
greater part of the entire dry matter. The relations of the remaining elements are largely obscure. Some of them form inorganic acids in the body, such as hydrochloric and sulphuric acids. Others form inorganic compounds deposited in the body as supporting or protective substances, such as the calcic phosphate and calcic carbonate of bone and spicules and the silicic oxide of plants. But there can be little doubt that a large and highly important part of these elements is built up into organic molecules and in this position plays a weighty and varied part in metabolism and growth. As examples of the way in which the metals and metalloids occur in the organic molecule I may cite a few cases in which the molecular structure has been determined more or less satisfactorily. Thus we have sulphur in albumen, $\mathrm{C}_{72} \mathrm{H}_{112} \mathrm{~N}_{18} \mathrm{SO}_{22}$; iron in hematin, $\mathrm{C}_{34} \mathrm{H}_{35} \mathrm{~N}_{4} \mathrm{FeO}_{5}$; phosphorus in lecithin, $\mathrm{C}_{42} \mathrm{H}_{84} \mathrm{NPO}_{9}$, and nuclein, $\mathrm{C}_{29} \mathrm{H}_{49} \mathrm{~N}_{9} \mathrm{P}_{3} \mathrm{O}_{22}$, magnesium in chlorophyllan, and various halogens in the urates of sodium, calcium, and lithium. In discussing as we shall immediately the importance of each of these elements for the formation of the body we shall find additional facts concerning the importance of the metallic atoms in the organic molecules. There is good reason for believing that the peculiar properties of hæmoglobin depend upon its iron and that the characteristic properties of nuclein depend largely upon its phosphorus and (as the later investigations indicate) its iron also. As our knowledge develops, the importance to many organic molcules in the living body of metallic or metalloid elements becomes clearer; the "ash" of the body is not something accidental, secondary, or superfluous, but is an essential part of the organism.

We must now consider the source of the various elements necessary to nutrition. Botanists early determined that $\mathrm{C}, \mathrm{H}$, and $\mathrm{O}$ enter the organism through the carbonic acid and water which green plants absorb. Concerning the source of nitrogen there has been less certainty ; it is generally believed to come from nitrates in the soil, but that matter will be considered later in more detail. Another source of the more characteristically organic elements, C, H, N, and O, is, without doubt, organic compounds of various sorts. Although it has long been known that insectivorous plants absorb the organic mat- 
ters they digest, still it is only recently that the fact that green plants in general can make use of organic compounds has been recognized. Bokorny (97) has lately brought together the evidence which makes this conclusion certain. It appears that in the presence of organic solutions some algæe may grow for half a year in the absence of carbon dioxide; and the potato plant may, even in the dark, store up starch in its tubers in the presence of rich organic food. Nitrogen may also be gained from amido-bodies ; thus, BÄssLer ('87) found that his maize cultures grew better in asparagin,

$$
\mathrm{CO}_{2} \mathrm{H} \cdot \mathrm{CH}\left(\mathrm{NH}_{2}\right) \cdot \mathrm{CH}_{2} \cdot \mathrm{CO}\left(\mathrm{NH}_{2}\right) \text {, }
$$

than in potassium nitrate. Thus plants may gain their $\mathrm{C}, \mathrm{H}$, $\mathrm{O}$, and $\mathrm{N}$ from either organic or inorganic sources.

Non-chlorophyllaceous organisms, on the other hand, have long been known to gain their $\mathrm{C}, \mathrm{H}, \mathrm{N}$, and $\mathrm{O}$ from organic compounds ; indeed, it has generally been believed that they can gain those elements from organic compounds only. Certain observations, however, Fia.84. $-a$, Nitrosomonas europæa (nithrow doubt upon the entire correctness of this belief; these are especially the remarkable results gained by WINOGRADSKY ('90) from nitrifying bacte-

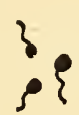

$a$
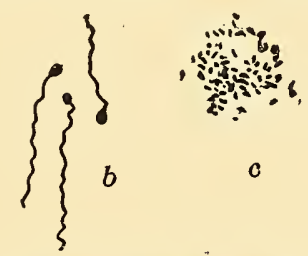
trite bacteria from Zürich); $b$, Nitrosomonas javensis (nitrite bacteria from Java); $c$, Nitrobacter (nitrate bacteria from Quito). Magnified 1050 . After Winogradsky, from Fischer, Vorlesungen über Bakterien, 1897. ria (Fig. 84). This author found that the bacteria could grow in a mixture of inorganic salts free of organic matters.

Solutions free from organic matter were prepared by the following means: The culture vessels were cleaned by boiling in them sulphuric acid and potassium permanganate. The water used in the cultures and in washing the ressels was twice distilled in vessels without joints of organic material - the second time with the addition of sulphuric acid and potassium permanganate. The magnesium sulphate and potassium phosphate, used as food, were calcined; the calcium carbonate, used in excess, was likewise calcined and saturated with carbon dioxide; finally, the ammonium sulphate was especially prepared to avoid organic impurities. The culture flasks were plugged with calcined amianthus, not with cotton. The solutions were inoculated with a mere trace of the culture containing nitrifying 
organisms. The cultures were then reared either in complete darkness or in dim light. The precautions taken to eliminate organic matters would seem to be complete; but those who know the difficulties of such experiments seem willing to admit the possibility "that exceedingly minute quantities of organic nitrogen and carbon are actually present" (JorDAN and Ricirards, '91, p. 880). On the other hand, "exceedingly minute quantities" of organic matter could hardly account for the vigorous growth of bacteria ; and, in general, a priori objections cannot be permitted to overthrow results gained by the use of methods which are beyond reproach.

The organisms placed in this water, deprived of the last traces of organic matter, developed rapidly, but not quite so rapidly as organisms placed in natural water to which the necessary salts had been added. Analysis showed that not only nitrates but also organic carbon compounds had been formed. 'Thus the careful experiments of WINOGRADSKY demonstrate what the less critical experiments of Herwus ('86) had already rendered probable, that a complete synthesis of organic matter may take place through the action of living beings and independently of the solar rays. These noteworthy observations, then, obliterate the last sharp line of distinction between the nutritive processes of chlorophyllaceous and non-chlorophyllaceous organisms. We may now state that the elements $\mathrm{C}, \mathrm{H}, \mathrm{N}$, and $\mathrm{O}$ may be gained from complex organic food materials by all organisms, and from simple compounds, such as carbonic acids, ammonia, and water, by all chlorophyllaceous organisms, and, very probably, by certain non-chlorophyllaceous ones also.

The elements other than $\mathrm{C}, \mathrm{H}, \mathrm{N}$, and $\mathrm{O}$ are probably gained by chlorophyllaceous and non-chlorophyllaceous organisms alike, from either inorganic or organic compounds containing the necessary elements; although, possibly, animals make use of the metals more readily when they are in organic compounds. Suitable proportions of the different metals in a nutritive solution for green plants are given in the following tables, showing various standard solutions employed by different experimenters : - 


\section{TABLE XXVIII}

Netritive Solutions for Phayerogays

SAchs' Solution

Distilled water

Gramues.

Potassium nitrate, $\mathrm{KNO}_{3}$.

$1,000.0$

1.0

Calcium sulphate, $\mathrm{CaSO}_{4}$.

0.5

Magnesium sulphate, $\mathrm{MgSO}_{4}$

0.5

Calcium phosphate, $\mathrm{CaHPO}_{4}$

0.5

Ferrous sulphate, $\mathrm{FeSO}_{4}$.

trace

Schinper's Solution ('90)

Distilled water

Calcium nitrate, $\mathrm{Ca}\left(\mathrm{NO}_{3}\right)_{2}$

600.0

6.0

Potassium nitrate, $\mathrm{KNO}_{3}$. . . . . . . . . . . . . $\quad 1.5$

Magnesium sulphate, $\mathrm{MgSO}_{4} \quad$. $\quad . \quad . \quad . \quad . \quad . \quad 1.5$

Neutral potassium phosphate, $\mathrm{K}_{3} \mathrm{PO}_{4}$. . . . $\quad 1.5$

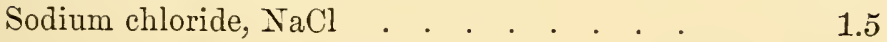

Fraxis's Solution

Water, $\frac{1}{2 T}$ distilled; $\frac{20}{21}$ Berlin reservoir water . 1,000,000.0

Calcium nitrate, $\mathrm{Ca}\left(\mathrm{NO}_{3}\right)_{2}$. . . . . . . . . . 267.4

Potassium chloride, $\mathrm{KCl}$. . . . . . . . . . . $\quad 121.5$

Potassium phosphate, $\mathrm{K}_{3} \mathrm{PO}_{4} \quad$. $\quad . \quad$. $\quad . \quad$. $\quad . \quad 101.9$

Magnesium sulphate, $\mathrm{MgSO}_{4} \cdot 7 \mathrm{H}_{2} \mathrm{O}$. . . . 100.2

Ferric chloride, $\mathrm{Fe}_{2} \mathrm{Cl}_{6}$. . . . . . . . . trace

The first differs from the others chiefly in the absence of chlorine.

How fit ordinary waters may be to provide all these salts is shown by this analysis of the ordinary drinking water of Boston (JordAN and Richards, '91) :-

TABLE XXIX

Parts by Weight of Inorgayid Matters in 1,000,000 Parts of Potable Water

Sulphuric acid . . . . . . . . . . 4.58

Chlorine . . . . . . . . . . . . 4.00

Alumina and oxide of iron . . . . . . 0.75

Calcium oxide . . . . . . . . . . . 6.45

Magnesia . . . . . . . . . . . . 1.60

Potash . . . . . . . . . . . . 0.92

Soda . . . . . . . . . . . 5.00

Silica . . . . . . . . . . . 3.04

Nitrates . . . . . . . . . . 0.25 
All of the elements mentioned above, except phosphorus, appear in this list. Thus, ordinary drinking water is clearly well adapted to the nutrition of plants.

For alga, MoLisch ('95) used the solution given in the following table :-

TABLE XXX

Nutritive Solution for Alge

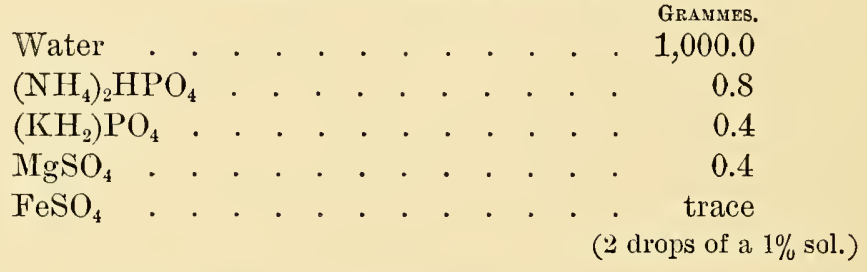

Here we note an absence of the calcium used in the solutions for phanerogams.

Fungi likewise require a mixture of salts, according to Nägeli ('80, p. 35t) and Benecke ('95), in the following proportions :-

\section{TABLE XXXI}

Nutritive Solutioxs for Fungi

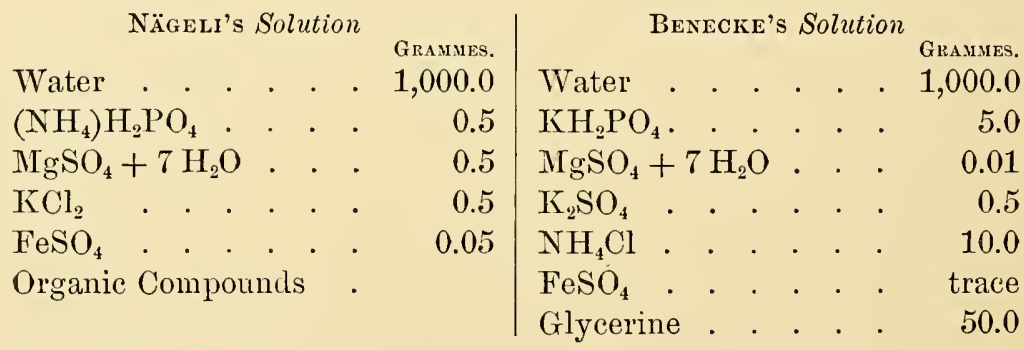

The solutions differ principally in the proportion of the salts.

Finally, all animals likewise require a certain quantity of salts. What the proportions are can be shown in the case of young mammals, which live during part of their growing period exclusively upon milk. A wonderfully close relation exists, indeed, between the proportions of the mineral constituents of milk and of the young mammal before it has begun to suck. This is shown in the analyses made by Bunge ('89) upon the milk of a dog and the body of its newly-born pup. 
TABLE XXXII

Couparison of Ash in New-born Dog and is the Milk of its Mother

\begin{tabular}{l|c|c}
\hline ASH. & $\begin{array}{c}\text { IN MILE: } \\
\text { \%o OF AsH. }\end{array}$ & $\begin{array}{c}\text { IN NET-BORN DOG : } \\
\text { \% OF AsH. }\end{array}$ \\
\hline $\mathrm{P}_{2} \mathrm{O}_{5}$ & 34.2 & 39.4 \\
$\mathrm{CaO}$ & 27.2 & 29.5 \\
$\mathrm{Cl}$ & 16.9 & 8.4 \\
$\mathrm{~K}_{2} \mathrm{O}$ & 15.0 & 11.4 \\
$\mathrm{Na}_{2} \mathrm{O}$ & 8.8 & 10.6 \\
$\mathrm{MgO}^{\mathrm{Ne}}$ & 1.5 & 1.8 \\
$\mathrm{Fe}_{2} \mathrm{O}_{3}$ & 0.12 & 0.72 \\
\hline
\end{tabular}

The quantities in the two columns are fairly similar. The greatest proportional difference occurs in the case of iron, and this fact requires a special explanation, which is briefly this, that iron is more important for the rapidly growing embryonic stages than for later life.

So likewise in the eggs of birds we find stored up all the mineral matters which are necessary for their development. Thus the yoke of the hen's egg contains phosphoric acid, lime, chlorine, potassa, soda, magnesia, iron oxide, and silica in the relative abundance indicated in this descending series. This series closely agrees with that given for milk.

In the case of marine animals, also, certain inorganic elements are a necessary food. The following list of such elements is based upon the results of thorough experiments by HERBsT (97) upon developing eggs of sea-urchins, starfishes, hydroids, ctenophores, and tunicates ; the most favorable proportions of the elements were not, however, determined: calcium (in the form of carbonate, sulphate, or chloride), chlorine, iron (trace), magnesium, phosphorus (as $\mathrm{Ca}_{3} \mathrm{P}_{2} \mathrm{O}_{8}$ or $\mathrm{CaHPO}_{4}$ ), potassium, sodium, and sulphur. Now all these elements are found in sea water, which in the Mediterranean Sea near Naples contains in 1000 parts of water * 


\begin{tabular}{|c|c|c|}
\hline \multicolumn{3}{|c|}{30.292 parts $\mathrm{NaCl}$} \\
\hline 3.240 & “ & $\mathrm{MgCl}_{2}$ \\
\hline 2.638 & “ & $\mathrm{MgSO}_{4}$ \\
\hline 1.605 & " & $\mathrm{CaSO}_{4}$ \\
\hline 0.779 & " & $\mathrm{KCl}$ \\
\hline 0.080 & $"$ & silicic acid, calcium phosphate, and insolu- \\
\hline
\end{tabular}

From the foregoing tables it appears that mineral substances, and essentially the same mineral substances, are required by all organisms. The differences in this respect between the different organisms are slight. Thus while sodium is not included among the necessary elements of either chlorophyllaceous plants or fungi, its occurrence in considerable quantity in milk, probably associated with chlorine as common salt, indicates that it is important for some animals.

The important conclusion seems warranted that all organisms may use as hylogenic food any sort of compound which will furnish the appropriate elements, but that among animals, and to a less degree among fungi, organic combinations have the preference because they fulfil at the same time the thermogenic function.

b. Detailed Account of the Various Elements used as Food.We may now consider the part which each element plays in the growth of the body as a whole, reserving for the Fourth Part a consideration of the specific rôle which the element plays in organs of the body. We may, in general, consider first the share taken by the element in the constitution of the body, then the form in which the element gains access to the body, and finally what general effect it has upon the growth of the organism.

Oxygen.-Excepting carbon, oxygen constitutes a greater part of the body, by weight, than any other element. Between $20 \%$ and $25 \%$ of the dry substance of the human body and between $35 \%$ and $45 \%$ of that of green plants is oxygen. The oxygen used as hylogenic food comes to land-animals from the organic compounds and the air consumed by the developing young; the oxygen of water-animals may come from their food or from the oxygen dissolved in water ; finally, 
that of phanerogams is believed to be gained chiefly from the air at all parts of the body, roots as well as stems and leaves.

Since oxygen is of great importance for metabolism (p. 2), it is naturally essential to growth. It is well known that the lower the oxygen tension is, the more slowly do seeds germinate and pass through their early stages of growth. Thus in an experiment performed by BERT ('78, pp. 848-853) barley grains which germinated and were reared at various pressures had in six days the following dry weights :-

\begin{tabular}{|c|c|c|c|}
\hline \multicolumn{3}{|c|}{ Atmospheric Pregsure. } & Resultivg Weight. \\
\hline \multicolumn{3}{|c|}{$76 \mathrm{~cm}$. mercury (normal atmosphere) } & $8.8 \mathrm{mg}$. \\
\hline 50 & $(0.66$ & " ) & 7.1 \\
\hline 25 & $(0.33$ & "، & 6.2 \\
\hline 7 & $(0.1$ & " & No growth \\
\hline
\end{tabular}

On the contrary, as the oxygen pressure increases up to about twice the normal, growth is accelerated, but beyond that point growth is retarded until at about 7 atmospheres growth hardly occurs.

In older seedlings, observations upon which have been made by Wieler ('83), Jentys ('88), and JACCARD ('93), atmospheric pressure below the normal, even down to one-fourth or one-eighth of the normal, appears to induce accelerated growth ; likewise in pure oxygen at the atmospheric pressure growth is as rapid as or somewhat more rapid than in the ordinary atmosphere. When, however, the oxygen tension is above the atmospheric pressure or below one-eighth of the normal, growth is retarded. It thus appears that an abnormal oxygen pressure may accelerate growth, and as we shall see later, the same effect is produced by other abnormal conditions.

Among animals, also, the oxygen tension exerts an important effect upon growth. This is shown by the experiments of Rauber ('84, pp. 57-65) upon the eggs of the frog.

To get a variable atmospheric pressure RAUBER used champagne flasks in which were put the eggs and a little water. Through the air-tight cork of the inverted flask one end of a U-shaped glass tube of proper length and strength was passed. To the other end was fixed a funnel through which 
mercury could be poured into the tube. The column of mercury produced the increased pressure in the flask, and the difference in height of the mercury in the two arms of the tube was a measure of this pressure. To get a pressure below the normal a partial vacuum was produced by a waterpump and the flask was then sealed. We assume (with BERT, '78, p. 1153) that the chief effect of the variation in the atmospheric pressure was the variation in the amount of oxygen absorbed by the water. Pure oxygen was also used in the flask.

At a pressure of three atmospheres no growth occurred. At a pressure of two atmospheres growth was slower than at the normal pressure. At three-fourths of an atmosphere also growth was retarded and at one-half an atmosphere death generally occurred. Thus the optimum condition of oxygen tension is near the normal for the atmosphere.

The same thing is indicated in a qualitative way by the experiments of Loes (92). The stems of the hydroid Tubularia possess in ordinary water a high regenerative capacity, but in water deprived of oxygen by boiling no regeneration takes place, although, after the water has been aerated again by shaking, rapid growth occurs.

Hydrogen.-This element forms, in its various compounds, between $5 \%$ and $10 \%$, by weight, of the dry substance of organisms. How is it acquired? In the case of plants it is believed that it is taken into the organism as a constituent of water, which combines with carbon or carbonic acid in the plant, forming either starch directly or some other compound from which starch is later derived. Other possible sources of hydrogen are ammonia and its compounds, also the organic compounds absorbed. The hydrogen of fungi and animals has clearly been derived from the latter compounds alone. The effect of hydrogen gas upon growth seems to be merely that due to the replacement of oxygen; it has no active effect.

Carbon is the largest constituent of dry organic matter, of which it forms between about $44 \%$ and $60 \%$. In green plants it is obtained for the most part from the carbon dioxide or carbonic acid of the air which is absorbed by the leaves. Other sources of carbon for green plants are found in many organic compounds, such as urea, uric acid, hippuric acid, glycocoll, kreatin, guanin, asparagin, lucin, tyrosin, and acetamid. These afford nitrogen also. Certain green plants make use of animal 
matter, e.g. insects, as food. Fungi and animals obtain their carbon from carbon compounds elaborated by plants. The indispensableness of carbon for the life of all organisms as well as for their growth requires no illustration.

Nitrogen. - Of the importance of nitrogen as a hylogenic food nothing more need be said than that it is essential to the formation of albumen. The ordinary form in which nitrogen is

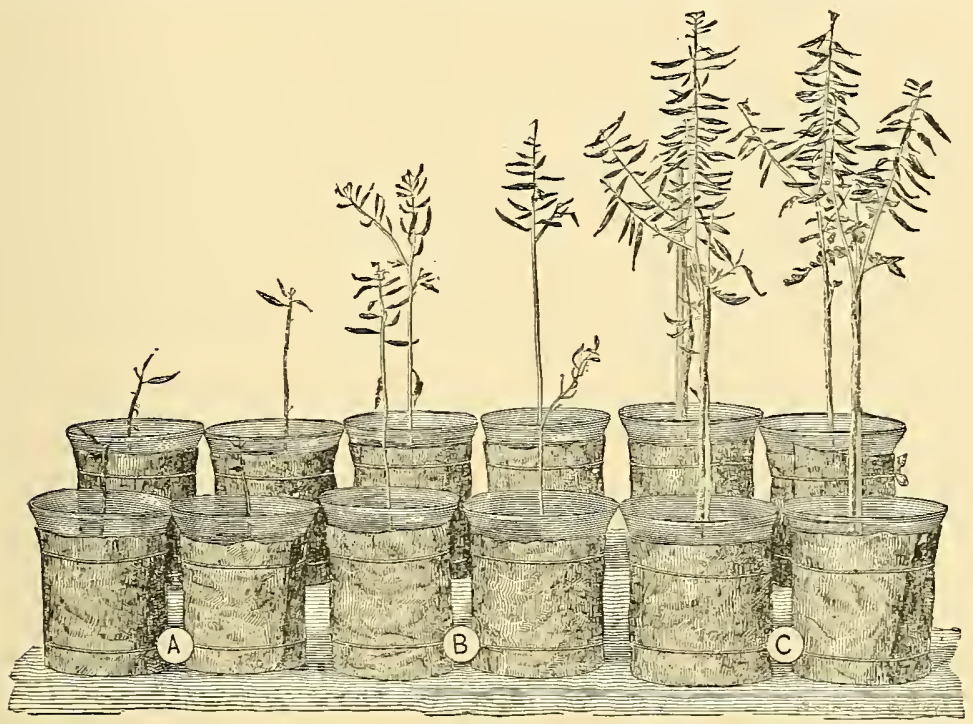

FIG. 85. - Cultures of Sinapis alba in pure quartz sand, to which hare been added equal amounts of a nutritive solution, but unequal quantities of nitrogen in the form of calcic nitrate, as follows: $A$, without nitrogen ; $B, 0.1$ gramme calcic nitrate in each vessel; $C, 0.6$ gramme calcic nitrate in each vessel. After a photograph. From Fraxk ('92).

obtained by the seedling is, as already stated (p. 298), that of the nitrates or ammonia in the soil (Fig. 85). Growing fungi gain it chiefly from nitrogenous organic compounds, but many fungi can make use of ammonium nitrate for this purpose. Growing animals gain nitrogen chiefly, if not exclusively, from organic compounds, especially albumen and allied substances.

Free nitrogen is found wide-spread in nature. It forms about $79 \%$ of the volume of the air; penetrates into water, though in a smaller proportion than in the air, and even into the soil. Thus for organisms living in any of these media free 
nitrogen is a possible food. Is it actually made use of ? This question has until recently usually been answered in the negative, and this conclusion was the more readily accepted since nitrogen is a notoriously inert gas.

Another view, however, has within recent years come to obtain. It developed in this wise. It had long been known that land which has lain fallow or on which clover or other leguminous crops have been reared is in a way strengthened as if fertilized, and it was also known that this strengthening is due to the fact that the soil acquires nitrogen from the air and "fixes" it in the form of nitrates. While the studies of PAsteur on fermentation, since 1862, had paved the way for the interpretation of the process, the fact that it is due to organisms was first proved by Schlösing and MünTZ ('77, '79). This proof they made by chloroforming a certain mass of nitrifying earth and finding that the nitrifying process thereupon ceased. Later, they isolated a form of bacteria which had the nitrifying property. Their results were quickly confirmed and extended by others, notably Berthelot ('85, '92, etc.), in a long series of investigations, so that there is now no question that the nitrification of the earth is brought about by the activity of bacteria, perhaps of several species.

The results thus gained were extended to some of the higher fungi by Frank ('92, p. 596).

Spores of Penicillium cladosporioides were sown in a nutritive solution of pure grape sugar and mineral salts, completely free of nitrogen, and in the presence of air which had been freed from ammonia by passing through sulphuric acid. The fungi grew, but not so rapidly as those in a solution containing nitrogenous compounds, and produced a mass of hyphæ. These hyphæ, when tested, yielded ammonia. One such culture solution of $65 \mathrm{cc}$. volume became filled with the fungus mass in ten months and yielded 0.0035 gramme of nitrogen, which must have been derived from the air.

As similar results have been gained for other molds by Berthelot ('93) and for Aspergillus and Penicillium glaucum by Puriewitsch ('95), we seem almost justified in predicting that the capacity for assimilating free, atmospheric nitrogen will prove to be a characteristic of all fungi.

Now if it is conceded that some organisms can make use of the nitrogen of the air, it is clear that the a priori objection to 
all organisms doing so, the objection, that is, on the ground of the inertness of nitrogen, is disposed of. The question is now merely one of fact. Do the algæ, the higher plants, and the animals make nitrogenous compounds out of free atmospheric nitrogen?

Of these groups, the algæ first claim our attention because of the inherent probability that they will act more like bacteria than any other group, since they pass over into the bacteria through such connecting forms as the Oscillariæ and Nostocs. Schlösing and Laurent ('92), Frank ('93), Koch and Kossowitsch ('93), experimented with various species of Nostoc, Oscillaria, Lyngbya, Tetraspora, Protococcus, Pleurococcus, Cystococcus, Ulothrix, etc., and found that, when supplied with a non-nitrogenous food, these plants produced nitrogenous compounds in the substratum, evidently gaining their nitrogen from the previously purified air.

Doubt exists, however, as to whether the free nitrogen is taken in directly by the algæ or only after having been assimilated by bacteria associated with the algæ and by them made into nitrogenous compounds. For the latter alternative speak the experiments of Kossowitsch ('94) and MoLisch ('95). Kossowitsch, who with KoCH had previously found that algæ gain nitrogen from the air when reared in impure cultures, now took special pains to get algal cultures free from bacteria. To this end he reared algæ on potassium silicate permeated by a nutritive solution. The pure cultures thus gained were then grown in a sterilized Hask to which air, freed from ammonia, was admitted. The nutritive solution was made of salts free from nitrogen but containing the other essential elements. The results of this experiment were striking. The pure cultures of algæ grew for a time, but then ceased. New nonnitrogenous food did not revive them, but the addition of nitrates caused rapid growth.

Other evidence was gained from analyses. When the cultures of algæ were pure there was no increase in the amount of nitrogen in the dry matter of the algæ. But when bacteria were mingled with the algæ, the quantity of nitrogen was increased. This is shown in the following typical analysis:- 


\begin{tabular}{|c|c|c|}
\hline \multirow{2}{*}{ Contenta of Culture. } & \multicolumn{2}{|c|}{ Milligrammes of N in Culture. } \\
\hline & At the Beginning. & AT THE END. \\
\hline Cystococcus, pure culture & 2.6 & 2.7 \\
\hline \multirow{2}{*}{ Cystococcus, with bacteria $\left\{\begin{array}{l}\text { no sugar } \\
\text { with sugar }\end{array}\right.$} & 2.6 & 3.1 \\
\hline & 2.6 & 8.1 \\
\hline
\end{tabular}

These results, abundantly confirmed by Molisch ('95), seem to show that unless bacteria are present algæ can build up free $\mathrm{N}$ into nitrogenous compounds only slowly, if at all.*

While Schlösixg and Müntz, Berthelot, and others were gaining an explanation of the enrichment of fallow ground, Hellriegel ("86) and Wilfarth were making their investigations upon the cause of the enriching action of leguminous crops, which led them to the conclusion that it was due to the fixation of nitrogen in plants with root-nodosities containing bacteria, the compounds thus formed by the symbiotic bacteria being directly assimilated by the plant. This conclusion has been repeatedly sustained for leguminous plants (Fig. 86).

The question whether green phanerogamous plants other than legumes can make use of free atmospheric nitrogen is one which is still in hot debate, and it is not an easy one to answer. The calm conviction, based chiefly upon the excellent work of Boussingault ('60), and Lawes, Gilbert, and Pugh ('61), that nitrogen is not thus obtained was rudely shaken by the paper of FrANK ('93) in which that author stated that he finds that nitrogen is removed from the air by non-leguminous plants-plants, moreover, which are not known to have bacteria living in their roots. Consequently he is of opinion that perhaps the fixation of free nitrogen may be carried on by any living plant cell.

The difficulties in the solution of the problem may thus be set forth. It is recognized that all growing plants make use

* One "crucial test" of Fraxk still requires an explanation. If the free nitrogen is "fixed" by the aid of bacteria, the process should go on in the dark. Experiment shows that it does not do so. This difficulty Kossowrtsch overcomes by the assumption that the activities of the bacteria are dependent upon certain carbohydrates which the plant can afford them only in the light. 
of nitrogen, but the nitrogen is usually obtained from the soil in the form of nitrates. It is feasible to determine by analysis the amount of nitrogen in the soil at the beginning of the experiment and the amount in the seed planted, and then after the experiment to determine the quantity in the soil and in the plant. But the difficulty comes in interpreting the results.

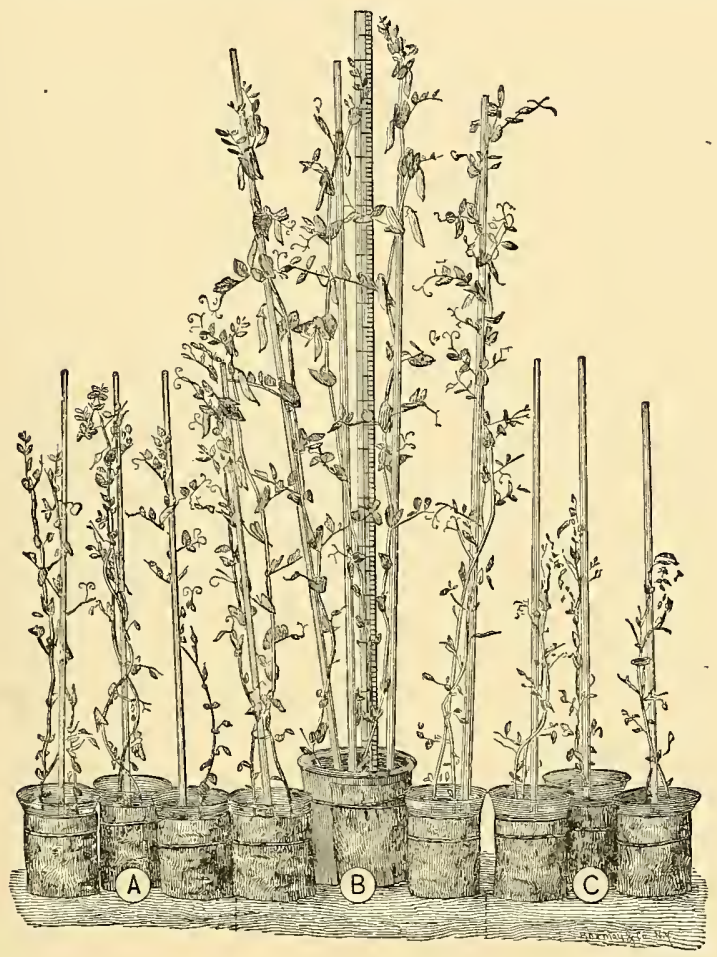

FIG. 86. - Parallel cultures of peas in the symbiotic and the non-symbiotic conditions. Each series comprises three culture vessels: $B$, the symbiotic plants in soil withont nitrogen; $C$, the non-symbiotic plants in like soil; $A$, for comparison, nonsymbiotic plants after addition of nitrate to the soil. After a photograph. (From FrANk, '92.)

of the analyses. Thus the fact that the sum of nitrogen in the plant and the soil is greater at the end than at the beginning of the experiment does not prove that the plant has taken in free nitrogen ; for, as we have seen, the soil contains nitrifying bacteria, which intermediate between the free nitrogen of the air and the nitrates absorbed by the green plants. This diffi- 
culty may be partly met by sterilizing the soil, but this probably produces also other changes than the death of the bacteria.

The most careful observations of the last five years have not supported FrANK's generalization. Here and there there have been observers who, like Liebscher ('92) and Stoklasa ('96), believe they have evidence for the direct assimilation of free nitrogen by the cells of phanerogams. But the evidence for the contrary opinion is predominant.

The experiments which speak for the theory that green plants canmot directly make use of free nitrogen are not in unison. Thus, some indicate that in non-leguminous as well as leguminous plants nitrogen of the air is indirectly made use of through the action of the bacteria of the soil, while according to others it would seem not to be made use of at all. To the first class belong the experiments of Petermane ('91, '92, and '93) with barley, of NoвBE and HrLtwer ('95) with mustard, oats, and buckwheat, and of PFErFFER and Franke ('96) with mustard. To the second class belong the experiments of Schlösing and LAurent ('92 and '92a) with various plants, DAY (94) with barley, and AEBy ('96) with mustard. In the second class, however, the experimental conditions did not favor the development of the bacteria of the soil. The experiments of Petermans were, however, carried out upon a very large scale and under practically normal conditions and showed a marked difference between the acquisition of nitrogen by barley growing in an unsterilized soil and in a sterilized one. Likewise NoBbe and Hiltwer, and PFEIFFer and Franke, were careful to rear plants under normal conditions, so that their results are worthy of especial consideration. They agree that there is an acquisition of nitrogen by the plant growing in normal soil and that this occurs only when the soil is unsterilized. We conclude then that probably phanerogams, like algæ, can use the free nitrogen of the air as food only after it has been converted into nitrates by the action of the nitrifying organisms - the bacteria of the soil.

Turning now to animals, whose nutrition is often compared with that of fungi, we find an absence of knowledge on the subject of the nutritiveness of free nitrogen. It is clear that 
land animals are in a favorable position for making use of it, since it penetrates with the oxygen to all parts of the body. It is found in the blood of mammals, but still as free nitrogen. Whether it eventually becomes fixed in the body is entirely unknown. The a priori argument against such fixation - the argument of inertness - has lost much of its force since the discovery of the nitrifying organisms.

Phosphorus. - This element is of constant occurrence in organisms. It has been found in yeast, mucors of the most diverse kinds, seeds, plant tissues, and animal tissues of all kinds. It is indeed one of the first among the mineral elements of most organisms, as shown on pages 296 and 297. Of the dry substance of a fish, about $7 \%$ is phosphoric acid, and the dry substance of many seeds yields $15 \%$. Phosphorus occurs in organisms as phosphoric acid compounds. Of these the most important organic compounds are nuclein, which has albuminoid properties, and occurs chiefly in all nuclei and in deutoplasm; lecithin, of a fatty nature, occurring in yeast, plasmodium of Athalium, seeds, milk, yolk of eggs, and nervous tissue; and glycerin-phosphoric acid, a product of decomposition of lecithin and found wherever the latter occurs. As examples of inorganic salts we have the sodium and potassium phosphates of the blood and tissues and the calcium phosphate deposited in bone.

So important an element as phosphorus would naturally form an essential part of the food of all growing organisms. It is supplied at first in the germ, - seed or egg, - but later must come from without. Plants gain phosphorus from the disintegrating rocks. Animals derive it chiefly from plants, directly or indirectly, or from the calcic phosphate of the sea; in mammals it is supplied to the developing young through the milk, which, as we have seen on page 303, is rich in phosphates.

The abundance of phosphorus in the body indicates that its office in the organism is an important one, and its peculiar abundance in seeds, yolk, and milk indicates that it is especially important in growth. Experiments have been directed towards this point. The fact has long been established that plant growth cannot occur in the absence of phosphates, and this is true not only for green plants, but also for molds and yeast 
(RAulin, '69). Embryos of various marine animals also will not develop in the absence of phosphorus (Herist, '97). The peculiar importance of phosphorus for growth is also indicated by the fact that HARTig and IVERer ('88) found more phosphoric acid in the ash of the growing ends of the plant than in its fully differentiated parts. Again, Loww ('91') found that Spirogyra kept in a nutritive solution of salts in which phosphorus alone was lacking, continned to live and, indeed, to form starch and albumen, but its cells did not grow or divide; so that LoEw concludes that an important use of phosphorus is to nourish the cell-nucleus, and this fact is easily understood from the known importance of the phosphorus-containing nuclein of chromatin in cell-division. All these facts go to show that phosphorus is of prime importance in the growth of organisms.

Arsenic, Antimony, Boron, and Bismuth, and their compounds, are apparently all injurious to organisms, so that sublethal solutions strong enough to be active, interfere with or even inhibit growth.

Sulphur. - This element is, without doubt, of constant occurrence in organisms of all sorts, for it constitutes between $0.3 \%$ and $2 \%$ of all proteids, out of which organic bodies are largely composed. Sulphur forms between $0.6 \%$ and $1 \%$ of varions (dry) organs of man, and nearly $1 \%$ of the dry substance of a month-old seedling of Sinapis alba.

In the growth of a plant (Sinapis alba) the amount of its. sulphur increases from $0.02 \mathrm{mg}$. in the seed to $84.4 \mathrm{mg}$. in the adult plant, and, indeed, it has been shown in one case (ARENDT, '59, for the oat plant) that the percentage of sulphuric acid in the ash increases from 2.9 to 4.2 as the plant develops from a seedling to maturity. Since the sulphur goes chiefly into the composition of the living substance, its hylogenic importance for growth is evident.

The form in which sulphur may be taken into the body is very varied. It is well known that green plants usually absorb it in the form of sulphates, especially sulphates of potassium, calcium, and magnesium; marine animals take it chiefly from the calcic sulphate of sea water, and land animals gain it largely from organic sulphur compounds produced in 
plants. Whether non-chlorophyllaceous plants can make use of it has been much discussed, and is worthy of further investigation. Wirogradsir ( $88, \cdot 89)$ has, indeed, shown that the sulpho-bacteria store up pure sulphur from sulphuretted hydrogen $\left(\mathrm{H}_{2} \mathrm{~S}\right)$, and Presch ('90) has concluded, as a result of feeding himself with pure sulphur and analyzing the sulphur of the urine, that about one-fourth of the sulphur taken into the body in an elementary form becomes built up into organic molecules. Recently Herbst (97) has shown that embryos

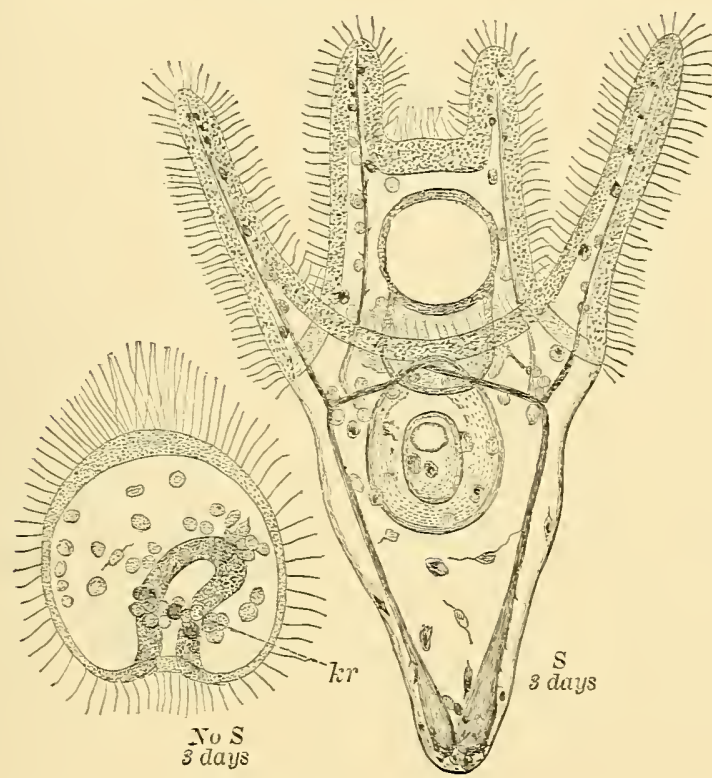

Fig. 87. - Right, Larva of Echinus reared for 72 hours in water containing all the necessary salts; the sulphnr being in the form of $0.26 \%$ magnesium sulphate and $0.1 \%$ calcic sulphate, and the phosphate in the form of $\mathrm{CaHPO}_{4}$. The larva is normal. Left, Larva reared for 68 hours in a solution containing no sulphur nor $\mathrm{CaCl}_{2}$. The typical larra without sulphur, but with $\mathrm{CaCl}_{2}$, differs from this chiefly in the presence of rudimentary spicules; $k r$, spicule-forming cells. (From Hersst, '97.)

of sea-urchins and other marine animals do not develop in the absence of sulphur (Fig. 87). These facts indicate that not green plants merely, but all organisms, can use elementary sulphur as a hylogenic food.

The Halogens, chlorine, bromine, iodine, and fluorine, are elements which are closely similar in their chemical reactions 
outside of organisms, and carry a part of that peculiarity with them into organisms. All of them are of physiological interest; but so far as we know chlorine and iodine are most important.

Chlorine. - This element is probably of constant occurrence in organisms, and indeed in rather large quantities, as Table XXVII, p. 297, shows. It is not strange that it should be so, since this element is very widely distributed in all waters. 'This very fact, however, renders it possible that chlorine is merely an accidental constituent of organisms, being unessential to growth, and precisely this conclusion has been maintained.

Of green plants it was early asserted that growth occurs as readily in solutions containing no chlorine as in ordinary potable water, but of late years evidence opposed to this view has been accumulating. Thus, while it appears that growth may occur in the absence of chlorine, Aschofe ('90) and others have found that growth is not so vigorous as in solutions containing this element. It has been thought that chlorine makes an advantageous combination with the potassium necessary for the plant, but the true significance of the favorable properties of chlorine remains undetermined.

Turning to animals, we find that chlorine occurs in the milk of mammals, and is therefore probably necessary to them. According to Herbst (97, p. 709) it is a necessary food for young echinoids. Certainly in the form of sodium chloride it is an essential food of the higher animals, and some of them, especially the herbivora, require large quantities of it, as "saltlicks" testify. The function of chlorine is not altogether plain. It must be used in the production of the hydrochloric acid of the digestive juices. In addition, sodium chloride is found widely distributed in the tissues. It has often been asserted that it goes through the tissues unchanged; but Nencki and Schoumow-Smranowsky ('94) believe that it is probably disintegrated and the chlorine built up into organic molecules.

Bromine. - The normal occurrence of traces of this element has lately been demonstrated by HotTer ('90) for a great variety of plants. It occurs most abundantly in various fruits, apple, pear, peach, and also in the leaves and twigs of many plants, as well as in various berries. Its normal occur- 
rence permits us to believe that it has an importance, if not for growth, at least for development; there is, however, no direct evidence that it is generally necessary to organisms. Since it is closely allied to chlorine, the question whether it may replace chlorine in growth has been tested. NExckI and SchounowSncarowsky (94) have found that in the higher animals the bromides can replace the chlorides to a limited extent, but are clearly less advantageous. Altogether the importance of bromine for growth is slight.

Iodine. - This element is of wide-spread occurrence-in organisms, probably as a constitnent of organic molecules, for it is found in plants, especially in some species of Fucus and Laminaria (cf. Eschle, '97); in invertebrates, especially in sponges and the stem of Gorgonia; and in vertebrates, especially in mammals, where it has recently been shown to be most important for growth. It has long been known that mammals which have been deprived of the thyroid gland acquire a weak condition of body known as myxœdema. This effect has been accounted for by the loss, to the organism, of a substance elaborated in the thyroid gland; for when the thyroid gland, or a docoction of it, is fed to the animal it recovers to a certain extent its normal condition. The nature of this substance has been investigated by BAUMANx and Roos ('96), who find that it is a compound of iodine - thyroiodine; for when thyroiodine is fed to the myxœdema patient, the same favorable result ensues as follows feeding upon the gland.

Fluorine is found rather widely distributed among vertebrates in very minute quantities. It forms about $1.3 \%$ of the total ash of bone. It is present also in the hen's egg, being more abundant in the yolk than in the albumen (TAminns, '88). Since it is chiefly found in the body as a constituent of bone, possibly in the form of the mineral apatite, $\mathrm{Ca}_{10} \mathrm{~F}_{2}\left(\mathrm{PO}_{4}\right)_{6}$, it may very well be that its chief importance is in the constitution of this formed substance. According to BRANDL and TAPPELxer ('92) the normal amount in the body may be greatly increased by feeding small quantities of sodium fluoride during a long period. Altogether, we have no reason for thinking that fluorine is essential to the growth of organisms in general. 
Salts of Alkalis. - This group contains one or two of the most important elements of which organisms are composed. The elements are only slightly replaceable by one another.

Lithium seems normally to have little importance for growth, although slight traces of it have been found spectroscopically in the blood (Hoppe-SEYLER, '81, p. 453).

Sodium is probably of constant occurrence in organisms. The quantity of it in the body is widely different in different species; and as our table on page 297 shows, it may vary in its position from one of the most abundant of the elements to one of the least. Whereas sodium is not essential to the nutrition of plants, it is necessary in the form of sodium chloride to certain higher animals. Sodium is also found in all the tissues of the body, and perhaps enters into the albuminoid molecule (Nencki,'94). The fact that, as we have seen on page 303, soda is a prominent constituent of milk, indicates its importance in the growth of mammals. Finally, Herbst ('97) has been able to demonstrate its indispensability for the growth of marine animals.

Potassium constitutes an important part of all organisms. It forms the largest part of the ash of nearly all phanerogams (see page 297) and is markedly abundant in yeast and in many invertebrates. It occurs in the body as chloride and as sulphate, and probably also in combination with albumen and various organic acids (VINES, p. 134).

That it is an essential and unreplaceable food for all organisms is indicated by trustworthy experiments upon fungi, algæ, phanerogams, invertebrates, and vertebrates. RAULIN ('69) first showed that only culture-solutions containing this metal permit the growth of fungi.

The experiments of BeNEcke ('96) upon the growth of certain molds, e.g. Aspergillus, are worth citing in detail as an illustration of the method.

He sowed spores in culture-vessels made of a glass which analysis had shown to be free from potassium. Two of these vessels contained a nutritive aqueous solution consisting of $3 \%$ cane sugar and $0.25 \%$ magnesium sulphate. To the one of these solntions was added $1.2 \%$ potassium nitrate, and $0.26 \%$ potassium phosphate; and to the other $1 \%$ sodium nitrate and $0.5 \%$ sodium phosphate. After four days the first culture was covered by a sheet of fungi and in five weeks the whole surface was black with spores; in 
the second eulture, on the other hand, little growth had occurred eren at the end of five weeks. The crop from each of the cultures was then harrested and its dry weight determined. That of the first culture was 0.3 gramme, that of the second 0.03 gramme.

By a somewhat similar procedure MoLisch (95) has been able to show that potassium is essential to the growth of algæ; and NoBbE and others (71) that it is necessary for the growth of phanerogams.

The experiments upon animals have been rather less satisfactory on account of the greater difficulties in experimentation.

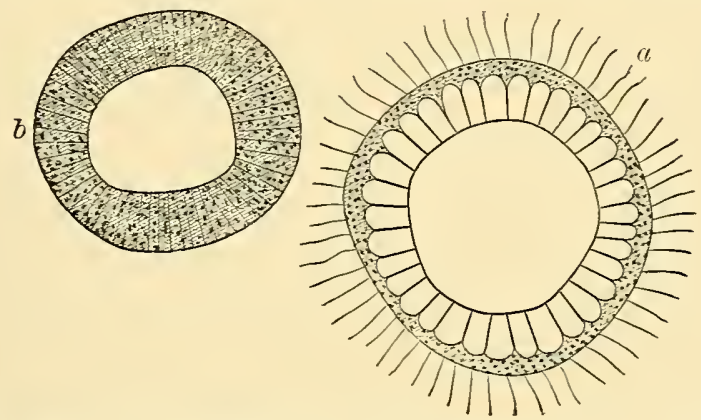

FIG. 88. - Two embrjos of Sphærechinus from parallel cultures. $a$, reared in a solution containing all the necessary salts; embryo normal. $b$, reared in the same solution, but without potassium; blastula wall abnormally dense, and embryo of small size. (From Herbst, '97.)

Nevertheless we have some trustworthy data upon this matter. On the side of the invertebrates we have the experiments of Lozb (92), who placed a hydroid, Tubularia, in fresh water to which solutions of various combinations of the salts found in sea water were added so as to give approximately the normal osmotic effect. Under these circumstances regeneration of the hydroids occurred only in the solutions containing potassium. Again, Herbst ('97) finds potassium essential to the growth of embryos of echinoids (Fig. 88). Thus the potassium compounds seem necessary to the processes upon which growth depends. On the side of vertebrates we have the somewhat inconclusive results of Kemnerich ('69), who fed two young dogs of the same age and of nearly the same size upon meat boiled until a large portion of its salts was extracted. To the food of one dog he added only sodium chlo- 
ride; to that of the other, both sodium chloride and potassium salts. After 26 days the dog fed on the potassium salts as well as the sodium chloride was about $30 \%$ heavier than the other, and this difference was reasonably ascribed to the beneficial effects of the potassium.

The particular part which potassium takes in growth is still somewhat doubtful. The recent observations of Copeland (97) with seedlings reared in water cultures in which sodium replaces potassium, lead him to the conclusion that potassium is necessary to turgescence. The potassium salts become lodged in the cell-sap, as analysis shows, and are therefore, perhaps, one of the principal causes of imbibition.

Rubidium and Cosium. - These rather rare metals are important only because of the fact that they may replace potassium in the growth of some fungi. WinOGRADSKY ('84) recognized this to be the case with rubidium in yeast cultures. NäGELI ('80) found that in molds rubidium and casium gave even greater growth of dry substance than potassium cultures, a conclusion abundantly confirmed by the studies of BENECKE (95). Whatever, therefore, is the significance of potassium for growtl, rubidium and cæsium seem to have the same significance.

Earthy Metals. - Under this head are included the elements calcium, strontium, and barium, which form compounds having closely similar molecular structure and properties. We might therefore expect them to be in some degree mutually replaceable.

Calcium shares with potassium and phosphorus the position of one of the most abundant elements of organisms. It is found in every tissue and seems to be a constant accompaniment of protoplasm.

Its constant occurrence is indicative of its importance as food for both plants and animals. It is apparently indispensable and unreplaceable by any other element in phanerogams; but MoLisch ('94) finds that growth can take place in certain molds (Penicillium, Aspergillus) as well in its absence as in its presence, and in some algæ, but not in all (MoLisch, '95), calcium is apparently of little importance. In animals, calcium can be replaced by other elements only to a very slight extent. 
Its absence from the water in which echinoid larve are developing produces dwarfs. In vertebrates, owing to the need of this metal for the skeleton, large quantities of calcium are taken in by the growing organism. In normal growth, then, the food of animals and phanerogams must contain calcium.

Strontium, although closely allied to calcium, is rather rarely found in considerable amount in organisms. In certain plants, as e.g. Fucus, it is constantly present. It can be stored up in the animal organism when supplied abundantly in the food, but in general is believed to be of little importance for growth.

Manganese, likewise, is not of general importance, although it is found abundantly in certain plants, e.g. Trapa natans, Quercus robur, and Castanea vesca, and in the excretory organ of the molluse Pimna squamosa (Krukexberg, '78).

Iron. - This most abundant of the heavy metals occurs so frequently in organic substances, especially those related to the compounds found in protoplasm, that it is little wonder that iron has been found to be an essential ingredient of all protoplasm, hardly less important than oxygen itself. Although its occurrence has been demonstrated, especially by ScHxEIDER ('89), in all the large groups of animals, its amount in any individual or organ is always very small. Iron oxide $\left(\mathrm{Fe}_{2} \mathrm{O}_{3}\right)$ forms between $1 \%$ and $2 \%$ of the ash of muscle, about $5 \%$ of the ash of blood, and rarely rises to $5 \%$ in plants.

It is found in the body, for the most part, as in yolk (Buxge, '85), in organic union. It occurs thus in the chromatin of the nucleus of all cells (MACALLUa, '92, '94; SCHNEIDER, '95).

That chromatin contains iron has been demonstrated by MACALLur ('91) by means of a microchemical method whose general validity has never, so far as I know, been questioned. It was shown by BuxGe, in 1885, that when tissue is put into ammonium sulphide the iron, even in an organic molecule, is separated from its compound, and uniting with the sulphur forms ferrous sulphide (FeS). This ferrous sulphide appears in the protoplasm as green granules (black in large quantity); and the fact that these gramules appear abundantly in the uncleus shows that iron is especially abundant there. Additional evidence is given if after several weeks the chromatin loses its stained appearance and becomes rusty. This result is interpreted as due to the formation of ferric oxide, $\mathrm{Fe}_{2} \mathrm{O}_{3}$; for when the 
nuclei are subjected to hydrochloric acid and potassium ferricyanide they immediately assume a deep azure-blue color, clearly due to the formation of "Prussian blue" or $\mathrm{Fe}_{4}\left(\mathrm{FeC}_{6} \mathrm{~N}_{6}\right)_{3}$. This series of reactions can only be explained on the ground that there is iron in the nucleus.

Iron has shown itself to be essential to the growth of all organisms. Its importance for growth is indicated by its relative abundance in the yolk of birds' eggs, and by the fact of its occurrence in larger proportion in a mammal just born than

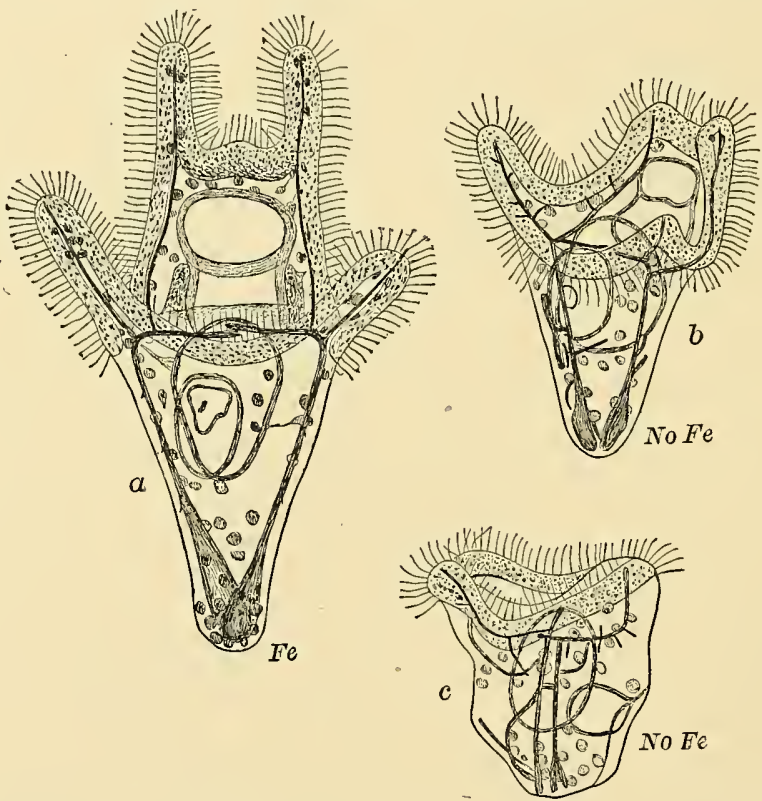

FIG. 89. - Echinus larvæ from parallel cultures, all $5 \frac{1}{2}$ days old. $\quad a$, reared in a solution containing all salts, including iron as $\mathrm{FeCl}_{3} ; b$ and $c$, from solutions containing all salts excepting iron. (From Herbst, '97.)

in later stages. When excluded from a mutritive solution which is otherwise complete, growth is imperfect (Fig. 89). This may be associated with the facts that in plants the chlorophyll granules are not developed in its absence, that in the higher animals hæmoglobin cannot be formed, and that the chromatic substance of all cells requires it.

The question in what form iron is absorbed by the organism has been the subject of an extensive discussion. Although doses of metallic iron have long been used with favorable 
results in medical practice, Burge ('85) concluded that only organic iron compounds are assimilable. The studies of Kuxkex ('91 and '95) and WoLtering ('95) have, however, shown in the clearest manner that inorganic iron is assimilated, stored in the liver, and made use of in the construction of such organic compounds as the hæmoglobin of the blood. At the same time, as Socir (91) and others hare shown, iron may be gained from organic compounds. Apparently, iron compounds of any sort may be made use of by the organism.

Magnesium. - This metal is closely associated with calcium, the two usually occurring together in organisms just as they do in the inorganic world. As the table on page 297 shows, magnesium is of constant occurrence among organisms, although never present in great quantity. The magnesium is gained by green plants at the same time with the calcium from mineral salts (chiefly magnesium carbonate and sulphate) derived from disintegrating rocks. Fungi can also make direct use of the salts of magnesium (excepting always the chloride); and animals, although no doubt chiefly gaining their magnesium from plants or the waters in which they live, may make use of mineral salts, especially in the construction of the mineral parts of various formed substances, such as those of bone.

So constant an element is presumably necessary to the organism, and numerous observations make it quite certain that this is true for green plants in general. Indeed, the fact that magnesium occurs in chlorophyllan of chlorophyll makes it probable that it functions in assimilation. Concerning its indispensableness for fungi there can likewise be no doubt, since BExECKE's ('95, p. 519) experiments show it to be replaceable neither by calcium, barium, or strontium. While some investigators, like HopPE-SEYLER, beliered it to have little siguificance for the animal body, - to be an accidental accompaniment of calcium, - later study has shown that it is of importance for regeneration of hydroids (LoEB, 92), and, according to Herbst ('97), a constituent of the sea water which is necessary to the normal growth of various marine larve. Also its occurrence, although slight, in milk, as well as its very abundant occurrence in seeds, indicate that it plays an important, if an unknown, part in growth. 
Silicon. - This element is of wide occurrence among organisms. In many plants, especially the grains and grasses, it is exceeded in abundance only by potassium. Among the lower organisms whole groups, e.g. diatoms, Radiolaria, and glass sponges, are characterized by the great amount of silica made use of. Even in vertebrates it is found wide-spread in the blood, gall, bones, feathers, and hair. The silicon required for the body is gained by plants and lower organisms from the soluble silicates or silicic acid of the soil and waters; by vertebrates, probably from plants.

Although SAchs ('87, p. 271) was able in 1862 to show that growth even of maize (about one-third of whose ash is silica) continues in the absence of silicon, yet some grains do better, according to WoLFF ('81), when that element is abundant. It is significant, likewise, that, as PoLeck (50) found, $7 \%$ of the ash in the albumen of the hen's egg is silicon.

Copper. - Brief mention may be made of the fact that this metal occurs in a great variety of organisms, but usually in minute quantity. It occurs as a physiologically important constituent of the hrmocyanine of the blood of the squid (FrEDERICQ, '78, p. 721), of crabs and lobsters, and of certain gastropods and lamellibranchs (Fredertce, '79).

2. The Organic Food used by Organisms in Growth. - All organisms may use organic compounds as food; all organisms which contain no chlorophyll, certain bacteria excepted, must do so. This organic food may consist of solutions of definite composition or it may consist of solid masses of plant and animal tissue composed of varied and indeterminate kinds of organic molecules. The former are made use of chiefly by plants ; the latter, by the higher animals. This distinction is, however, not a necessary and constant one, for on the one hand insectivorous plants and many fungi live upon solid masses which they digest, and on the other hand some of the Protozoa can be fed upon known solutions, and doubtless some of the higher animals could be likewise fed, although few experiments seem to have been made in this direction. Even in methods of nutrition there is no sharp line to be drawn between the different groups of organisms.

a. Fungi. - Our knowledge of the effect of known chemi- 
cal compounds used as food has been much more advanced by studies upon this group than upon any other. Yeast and bacteria have been especially investigated, but valuable results have been obtained upon the higher fungi also. Considering all these results together, it appears that the nutritive value of an organic compound is perhaps chiefly determined by its assimilability; that is, the less the energy required to attack and transform the compound by the various chemical means at hand, the more favorable it is as a food. This assimilability depends in turn upon the molecular structure - upon a certain molecular instability or lability - upon the possession of that quality which is found in its extreme expression in many organic poisons. As LoEw ('91, p. 761) has expressed it: Poison action, like nutritive action, is a relative conception. An indifferent body can become, by entrance of one atom-group, a nutritive substance; by entrance of an additional atom group, a poison. While a certain lability - that is, a certain degree of ease of decomposition - is a condition of the nutritive quality of a substance, a slight increase of this lability can give it a poisonous character, especially when the loosely arranged atoms can link into that atom-grouping upon which the vital movement in the protoplasm depends. 'Thus methan is indifferent for bacteria, methylalcohol is a nutritive substance, formaldehyd is a poison, and its combination with sodic sulphate again a nutritive material.*

Additional laws of nutritive value which hold true in many cases are as follows: The assimilable carbon compounds contain the group $\mathrm{CH}_{2}$ or at least $\mathrm{CH}$. Under otherwise similar conditions, compounds with one carbon atom are assimilated with great difficulty (methylamin) or not at all (formic acid, chloral); and, in general, but with important exceptions in the case of certain classes of substances, the assimilability increases as the number of carbon atoms in the molecule increases. The

* The graphic formulas of these substances are :-
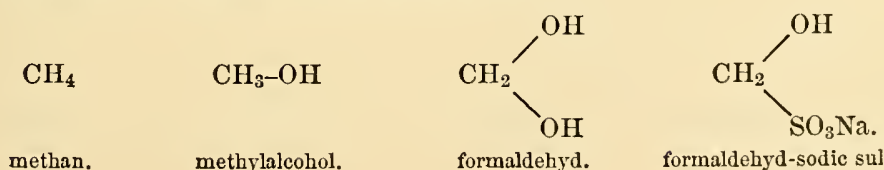

methan. methylalcohol.

formaldehyd.

formaldehyd-sodic sulphate. 
radical $\mathrm{HO}_{-}$is usually easily released, consequently we find compounds containing this radical in general more assimilable than allied compounds in which the $\mathrm{HO}$ - is replaced by $\mathrm{H}$. Especially is this true when the $\mathrm{HO}_{-}$is joined with radicals containing carbon and hydrogen atoms. For example, foods with the radical $-\mathrm{CH}_{2} \cdot \mathrm{OH}$ are more nutritive than those with $-\mathrm{CH}_{3}$. Hydroxylized acids are better food for bacteria than non-hydroxylized - lactic acid, $\mathrm{C}_{3} \mathrm{H}_{6} \mathrm{O}_{3}$, is better than propionic acid, $\mathrm{C}_{3} \mathrm{H}_{6} \mathrm{O}_{2}$. It is, perhaps, a special case under this rule that multivalent alcohols - i.e. those containing several $\mathrm{HO}$ groups - are better foods than the univalent ones; for instance, glycerine, $\mathrm{CH}_{2} \mathrm{OH}-\mathrm{CHOH}-\mathrm{CH}_{2} \mathrm{OH}$, is better than propylalcohol, $\mathrm{CH}_{3} \cdot \mathrm{CH}_{2} \cdot \mathrm{CH}_{2} \mathrm{OH}$. Finally, the entrance of the extremely unstable aldehyd (-CH:O) and keton $(-\mathrm{CO}-)$ groups increases the nutritive capacity of the food; for example, glucose, $\mathrm{CH}_{2} \mathrm{OH} \cdot(\mathrm{CH} \cdot \mathrm{OH})_{4} \mathrm{CHO}$, or fructose, $\mathrm{CH}_{2} \mathrm{OH} \cdot(\mathrm{CH} \cdot \mathrm{OH})_{3} \cdot \mathrm{CO} \cdot \mathrm{CH}_{2} \mathrm{OH}$, is better than mannit, $\mathrm{CH}_{2} \mathrm{OH} \cdot(\mathrm{CH} \cdot \mathrm{OH})_{4} \cdot \mathrm{CH}_{2} \mathrm{OH}$. But all substances containing the group $\mathrm{CHOH}$ are good foods, since this compound can be used directly in the construction of carbohydrates, and eventually of albumen.

As an example of the application of these general principles may be given this series of substances arranged in the order of their decreasing nutritive value for yeast and molds (N ̈̈GELI and Loew, '80): 1, sugars; 2, mannit, glycerine, the carbon groups in leucin; 3, tartaric acid, citric acid, succinic acid, the carbon groups in asparagin; 4, acetic acid, ethylalcohol, kinic acid; 5, benzoic acid, salicylic acid, the carbon groups in propylamine; 6 , the carbon groups in methylamin, phenol.

In conclusion may be mentioned a food for bacteria which, although inorganic, resembles organic compounds in that it may serve as a source of energy. 'This is the hydrogen disulphicle employed by the sulphur bacteria and allied forms (WINOGRADSKY, '87, '89).

b. Green Plants. - It has already been shown that organic compouncls can be assimilated by green plants. The experiments which have shown this have been made upon both algre and phanerogams, especially by Bokorxy, Loew, A. Mexer, and LAURent. It appears that, in the absence of carbon 
dioxide, Spirogyra may form starch from methylalcohol, formaldehyd, glycol, methylal, acetylethylesteracetat, acetic acid, lactic acid, butyric acid, succinic acid, phenol, asparaginic acid, citric acid, acid calcium tartrate, ammonium tartrate, calcium bimalate, glycocoll, tyrosin, leucin, urea, hydantoin, kreatin, and peptones.* Phanerogams form starch from glycerine, cane sugar, levulose, dextrose, lactose, maltose, mannit, dulcit, and lecithin. While daylight favors assimilation it can be in some cases dispensed with. Thus the potato plant can accumulate starch in the dark when glycerine is used as food.

An attempt to gain a deeper insight into the conditions of formation of albumen from organic matter has been made by HAxsteen ('96), who reared Lemna in solutions of grape sugar or cane sugar, on the one hand, and amids, like asparagin, urea, glycocoll, leucin, alanin, or kreatin, on the other; also on grape sugar and inorganic nitrogenous bodies such as potassium nitrate, sodium nitrate, ammonium sulphide, and ammonium sulphate. As a result of feeding on grape sugar alone at $20^{\circ} \mathrm{C}$. during 24 hours, much starch was stored in the cells; when grape sugar and inorganic nitrogenous bodies were combined little starch and much albumen were produced. Much albumen was also gained when the nutritive solution contained cane sugar and urea, or asparagin and ammonium chloride, or asparagin and ammonium sulphate. The production of albumen in green plants is favored by nitrogenous organic compounds.

c. Animals. - These organisms are distinguished from the foregoing by an immense requirement of energy for their muscular processes, much of which is continually lost to the organism in the form of motion communicated to the environment. On the other hand, growth is generally slower than in plants. Consequently in animal nutrition thermogenic foods are the more important and the nutritive processes are prevailingly exothermic. The plastic processes are the less striking; nevertheless, it is they which chiefly concern us in our study of growth.

Among the organic compounds ingested, carbohydrates are

* The reagents were employed in about $0.1 \%$ solution, and whenever acid were neutralized with lime-water. 
believed to have little importance as plastic foods - we have chiefly to consider the use of the complex fats, albuminoids, and other organic compounds. We can make little use of the extensive tables of calorific properties of foods which, however important for determining capacity for supplying energy, afford little insight into the plastic properties of the food its importance for the growth of dry substance or the imbibition of water.

The difficulties in the way of feeding animals upon known nutritive solutions are great, both because solutions are not their normal food, and because, in the case of water organisms, the bacteria introduced with the animals thrive better than they. Consequently the observations on nutritive compounds for animals are meagre. It will be best to consider them under the types upon which they have been made.

Amceba. - We owe important studies on the foods of Amoba to the fact that some species have a pathogenic importance. Cultures of them have therefore been made by bacteriological methods. It is found that various, even innocuous kinds, will grow upon egg albumen in distilled or phenylated water kept at about $15^{\circ}$ C. (Criveldi et MAgGi, '70, '71; Monti, '95), upon agar-agar sheets from which the soluble substances have been removed by repeated washing in distilled water (BEYERINCK, '96), upon "Fucus [Chondrus?] crispus" (Celli, '96), or upon slices of potato (Gorini, '96). It is thus clear that, in addition to salts, Amœba needs only a very simple nitrogenous diet. It is, however, uncertain whether the amœba feeds directly from the organic food stuff, or indi-

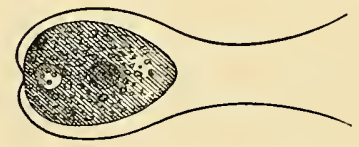

Fig. 90. - Polytoma uvella, a tlagellate infusorian. (From VerworN, 95.) rectly upon the bacteria which grow upon the food supplied.

Infusoria. - A beginning has been made in the study of this group by Ogata ('93), who reared pure cultures of the flagellate Polytoma uvella (Fig. 90 ) on plates of nutrient gelatine (which is extremely rich in protein) and also upon a medium composed of $500 \mathrm{ccm}$ : meat bouillon, 12.5 grammes grape sugar, and 250 grammes of a Japanese mixture of algæ called "nori," derived mostly from the species Porphyra vulgaris. 
The mixture was cooked, neutralized, filtered, sterilized, and infected with the flagellates, which had been isolated by means of capillary tubes. Here again growth was supported by simple, definite foods.

Amphibia. - It is a great leap from Protozoa to vertebrates, but precise feeding experiments are almost lacking in the invertebrate Metazoa. In the present group come the pioneer experiments of YUNG ('83). This author fed a number of tadpoles derived from the same batch of eggs upon foods of various kinds in unlimited quantity and under otherwise similar conditions. After forty-two days the size of the tadpoles in each lot was measured and the following results were obtained : -

\section{TABLE XXXIII}

Results of Feeding Tadpoles on Various Substances

\begin{tabular}{|c|c|c|c|c|c|c|}
\hline No. of Trasel. & $\mathbf{1}$ & 2 & 3 & 4 & 5 & 6 \\
\hline $\begin{array}{l}\text { Kinds of } \\
\text { Food. }\end{array}$ & $\begin{array}{c}\text { Aquatio } \\
\text { Plants: } \\
\text { ANacharis } \\
\text { AND } \\
\text { Spirogyra. }\end{array}$ & $\begin{array}{c}\text { A LbUMinots } \\
\text { EgG ENIE- } \\
\text { LOPE OF } \\
\text { Frog. }\end{array}$ & $\begin{array}{l}\text { Pieces of } \\
\text { Yolk of } \\
\text { Hen's EGg. }\end{array}$ & $\begin{array}{c}\text { Albumen } \\
\text { of llen's } \\
\text { EgG. }\end{array}$ & $\begin{array}{l}\text { Pieces } \\
\text { of Fish } \\
\text { Flesh. }\end{array}$ & $\begin{array}{c}\text { Pieces } \\
\text { of BefF } \\
\text { F Lesh. }\end{array}$ \\
\hline $\begin{array}{l}\text { Length of } \\
\text { tadpole }\end{array}$ & 18.3 & 23.2 & 26.0 & 33.0 & 38.0 & 43.5 \\
\hline $\begin{array}{l}\text { Breadth of } \\
\text { tadpole }\end{array}$ & 4.2 & 5.0 & 5.8 & 6.6 & 8.8 & 9.2 \\
\hline
\end{tabular}

It will be observed that the importance for growth was not proportional to the calorific properties of the respective foods, for the yolk of the hen's egg has about 40\% higher fuel value than dry egg albumen or dry flesh. The least growth occurred with a plant food which is relatively rich in carbohydrates, and has some protein and little fat; the third greatest growth occurred with the yolk, which has more fat than protein; next comes egg albumen, with more protein than fat; and, finally, fish and beef flesh, characterized by their high percentage of nitrogenous matter. The tadpole grows fastest on a highly nitrogenous diet. 
Additional experiments upon the frog's egg have been made by DANilewsiry (95), who found that such eggs placed in water containing $\frac{1}{15000}$ of lecithin gained in 54 days $300 \%$ greater weight than those reared in pure water. The author believes, however, that this small quantity cannot act in a directly nutritive manner but, rather, that it favors in some way the assimilation of food.

Mammals. - The requirements of agriculture have led to numberless experiments upon the feeding of domesticated mammals. Yet they are for the most part of little value for our purpose. A few of the better class of experiments from our point of view may be given, together with such conclusions as they permit.

Years ago, Lawes and Gilbert ('53), from extensive feedings of sheep and pigs, upon diverse foods, reached the conclusion that those "apparently grew more where, with no deficiency of other matters, the nitrogenous constituents were very liberally supplied. Hence, the gross increase obtained might be somewhat more nitrogenous with the large supply of nitrogenous food; but it would in that case, according to some experiments of our own, contain a larger proportion of water, and less of solid matter, than where more fat had been produced." More recent studies made on various domesticated animals tend to confirm these results. A mixed diet with an abundance of nitrogenous food permits of greater growth than an equal quantity of food of one kind, or mixed food in which the nitrogenous constituent is scant. Growth tends to increase with the quantity of nitrogenous food rather more closely than with that of the non-nitrogenous food devoured.

This conclusion is sustained by the striking results gained by Prösher ('97) in investigating the cause of the varying percentage rate of growth of different mammals. The relation between growth and the percentage of the different organic and certain mineral constituents of milk is given in the following table :- 


\section{TABLE XXXIV}

Showing for Various Mammals the Time required to double the Birthweight, the Percentage of Different Organic Constituents in the Mili, and the Relative Quantity of Albumen, Calcium Oxide, and Phosphoric Acid in the Milk of the Different Species-the Quantity in Man being taken as the Standard

\begin{tabular}{|c|c|c|c|c|c|c|c|c|c|c|}
\hline \multicolumn{4}{|c|}{1} & 2 & 3 & 4 & 5 & 6 & $y$ & 8 \\
\hline \multicolumn{4}{|c|}{ SPECIES. } & $\begin{array}{l}\text { Relative } \\
\text { Time to } \\
\text { Double } \\
\text { Weight. }\end{array}$ & $\begin{array}{c}\% \\
\text { FAT. }\end{array}$ & $\begin{array}{c}\% \\
\text { StGAR. }\end{array}$ & $\begin{array}{c}\% \\
\text { AlbuMeN. }\end{array}$ & $\begin{array}{l}\text { ReLaTIVE } \\
\text { QUANTITY } \\
\text { A LBUMEN. }\end{array}$ & $\begin{array}{l}\text { Relative } \\
\text { Quantity } \\
\text { CaO. }\end{array}$ & $\begin{array}{l}\text { Relative } \\
\text { QUANTITY } \\
\mathrm{P}_{2} \mathrm{O}_{5} \text {. }\end{array}$ \\
\hline Man . & . & . & . . & 1 & 3.5 & 6.6 & 1.9 & 1.0 & 1 & 1 \\
\hline Horse & . & . & . & $\frac{1}{3}$ & 1.1 & 6.1 & 2.3 & 1.2 & 4 & 3 \\
\hline $\mathrm{Ox}$. & . . & . & $\cdot$ & $\frac{1}{4}$ & 4.5 & 4.5 & 4.0 & 2.2 & 5 & 4 \\
\hline $\operatorname{Pig}$. & . . & . & . . & $\frac{1}{10}$ & 6.9 & 2.0 & 6.9 & 3.7 & - & - \\
\hline Sheep & . & . & . & $\frac{T}{\frac{T}{1} 8}$ & 10.4 & 4.2 & 7.0 & 3.8 & 8 & 9 \\
\hline Dog & . & . & • & $\frac{\pi}{x^{2}}$ & 10.6 & 3.1 & 8.3 & 4.45 & 14 & 10 \\
\hline Cat. & . & . & . & $\frac{1}{36}$ & 3.3 & 4.9 & 9.5 & 5.1 & - & - \\
\hline
\end{tabular}

From this table it is clear that there is a close relation between rate of growth and the percentage of albumen only among the organic substances of milk. This relation is best brought out by comparing columns 2 and 5 . The last two columns show a close relation between growth and the quantity of calcium and phosphorus in the milk. But of the organic substances the quantity of the nitrogenous compound determines the rate of growth.

3. Growth as a Response to Stimuli. - Hitherto we have regarded the process of growth in too mechanical a way, as though certain nutritive compounds, passing into a chemical mill, were inevitably transformed, at a certain rate, into protoplasm or formed substance. We have now to recognize that the growth processes are essentially vital processes, and, as such, characterized by all that complexity which we find in such a vital process as response to stimuli.

a. Acceleration of Growth by Chemical Stimulants. - Many chemical agents which are not themselves food may stimulate the growth processes. We have already seen (p. 51) how certain poisons cause, in dilute solutions, accelerated move- 
ments and heightened metabolism. To the cases previously given may be added the experiments of ScHulz ('88), who found that various poisons, such as corrosive sublimate, iodine, bromine, and arsenious acid, increase the activities of yeast in fermentation. It is not strange, therefore, to find that poisons may, at a certain concentration, accelerate growth. That they do so follows from the experiments of Richaros ('97), who reared the molds Aspergillus, Penicillium, and Botrytis in nutritive solutions to which had been added small quantities of zinc sulphate, other metallic salts, cocaine, morphine, and other alkaloids. After five to seven days Aspergillus, reared in nutritive solutions in which sugar was the organic compound, had gained the following dry weights (in milligrammes). In all the.experiments, except those in the column headed "Control," the solution contained certain non-nutritious substances in from $0.002 \%$ to $0.033 \%$ concentration.

\section{TABLE XXXV}

Showing the Total Dry Weight in Milligramies of a Crop of Aspergillus reared in the Absence and in the Presence of Varying Quantities of Irritating Substances

\begin{tabular}{|c|c|c|c|c|c|c|}
\hline Substaxce. & Control. & $0.002 \%$ & $0.004 \%$ & $0.008 \%$ & $0.016 \%$ & $0.033 \%$ \\
\hline $\mathrm{ZnSO}_{4}$ & 335 & 730 & 760 & 765 & 770 & 715 \\
\hline $\mathrm{NaFl}$ & 250 & 565 & 405 & 340 & 270 & 245 \\
\hline $\mathrm{Na}_{2} \mathrm{SiO}_{3}$ & 350 & 520 & 575 & 450 & 435 & 380 \\
\hline $\mathrm{CoSO}_{4}$ & 245 & 405 & 350 & 235 & 170 & 75 \\
\hline Cocaine & 280 & 410 & 320 & 350 & 390 & 540 \\
\hline Morphine & 160 & 155 & 170 & 140 & 210 & 215 \\
\hline
\end{tabular}

It is clear from this table that the addition of even small quantities of innutritious and poisonous substances may so excite the hylogenic processes as to cause twice or even far more than twice the normal formation of dry substance in a given time, and that this excessive growth increases with the concentration of the salt up to a certain optimum, beyond which growth declines again to below the normal. Similarly Townsend (97) has observed that a seedling living under a bell jar whose atmosphere contains a small quantity of ether grows 
faster than one under similar conditions but without ether. If the plant is subjected to an increased quantity of ether, growth is retarded. The effect of these poisons is thus very different from that of nutritive substances; it is due to the irritating properties of the poison.

b. The Election of Organic Food.-Not all of the food-stuff presented to the organism is utilized by it - neither, on the one hand, all of the kinds of food, nor, on the other, all of the food of the most acceptable kind if offered beyond a certain amount. There is an election of kind and of amount. A study of an election of kind has been made by Duclaux ('89), and, especially, PFefrer ('95). The method employed was this: To the organisms (various molds, Aspergillus, Penicillium, etc.) were offered two compounds; one more nutritious, the other less so. Under these circumstances, the more nutritious compound was usually taken by the organism, while the less nutritions was often left entirely alone; thus, dextrose was preferred to glycerine, peptone to glycerine, and dextrose to lactic acid, even when, in each case, the quantity of the latter substance was in excess of the former. The election was not, however, always of the more nutritious material, so far as we can judge of relative nutritiveness. 'Thus, when Aspergillus was sown on a nutritive fluid, containing $8 \%$ dextrose and $1 \%$ acetic acid, proportionally far more of the latter was assimilated than of the former, although the latter is of less value as food, as was shown by the fact that the plant had also to devour a considerable quantity of the dextrose. This extensive assimilation of a slightly nutritive substance is not, so far as we can see, an adaptive process.

The character of the election may change with age, so that what is favorable for growth at one time is not at another. Thus Duclaux ('89) found that alcohol restrains or arrests: the germination of the spores of molds, whereas it is made use of almost as abundantly as sugar by the adult plant; so, likewise, lactose and mannit cannot nourish young plants when they replace sugar in the nutritive solution, whereas they are a good food for the older plants.

So, also, among vertebrates, the food of the young, supplied in the egg or in the milk of the parent, is very unlike that 
which is most favorable for growth in later stages. So important is this difference of food at different ages that agriculturists persistently change the ratio of the different foods supplied as their animals increase in age. 'The reason for this change in food required lies doubtless in this, that the chemical processes of growth change with the age of the animal ; at first imbibition of water predominates, then comes the secretion of the various formed substances of the organism and the constant maintenance and increase of the plasma. The most favorable food of an organism at any time is dependent upon the metabolic processes going on at that time.

The election of quantity is not less striking. It is well known that an increase above a certain limit in the amount of food presented to an organism or even actually taken into its body does not result in any increase in growth. There is a certain amount, fixed within broad limits, which corresponds to a maximum of nutritiveness. This amount, this feeding capacity, is not, however, necessarily constant at all stages of the adult growth of the organism. For it has been observed in certain animals, e.g. pigs, that as they grow older there is a steady increase in the amount of food required to produce a pound of gain in weight. Such facts serve to indicate that the rate of growth is largely determined by internal factors.

Let us now summarize the results of this study of the effect of chemical agents upon the rate of growth. Of foods, those used in the plastic processes are chiefly to be considered. The substances serving as plastic food must contain all the elements normally occurring in the organism. These are found in diverse proportions in different organisms, and hence the necessity of dissimilar foods. Not only carbon, oxygen, hydrogen, and nitrogen are necessary, but a whole series of other elements, such as phosphorus, sulphur, chlorine, iodine, sodium, potassium, calcium, iron, and magnesium are more or less essential. The organic plastic food varies with the group of organisms. Of relatively little importance for green plants, it becomes essential to fungi. In this group we find the most important character of a nutritive substance to be a certain degree of lability. Among animals a mixed diet is especially beneficial, but nitrogenous food favors growth more than non-nitrogenous 
food. Finally, growth must be studied as a response to ehemical agents which may stimulate the protoplasm to absorb and assimilate them to the degree required by the organism, or which may stimulate the protoplasm to absorb some other substances, as we have seen in the case of zine sulphate. The quantity and quality of food needed will, moreover, vary with the age and other qualities of the organism. The consumption of food both in quantity and in quality will be closely determined by the demand. All these complexities in the process of nutrition indicate that it, like other processes in organisms, can only be explained on the assumption of a vastly complex molecular organization of the protoplasm.

\section{\$2. Effect of Chemical Agents upon the Direction of Growth - Chemotropism}

One of the most common processes in the early development of organisms is the turning or bending of a filament, tubule, or lamella. The cause of this turning is clearly an unequal growth of the two sides of the organ. When the bending organs are internal, their movements are largely removed from experimental study; when external, as in plants, they more easily lend themselves to our investigation. The object of this investigation is always to find in how far the direction of these tropic movements is determined or is determinable by external agents.

In the present section it is proposed to consider in how far tropic movements are determined by chemical agents. At the outset it must be said that the growth which gives rise to these bendings is frequently due to imbibition of water; and in such cases it may be only temporary. Yet these temporary bendings pass by such insensible gradations into permanent ones that a sharp distinction between the two is impracticable and unimportant. Rejecting such a classification of the subject, we may adopt one based on the tropic organ.

1. Chemotropism in the Tentacles of Insectivorous Plants. This case of chemotropism was the earliest to be observed; it was Darwin ('75, p. 76) who first called attention to it. $\mathrm{He}$ found that when drops of water or solutions of non-nitrogenous 
compounds are placed upon the leaves of the sundew, Drosera, the tentacles remain uninflected; but when a drop of a nitrogenous fluid, such as milk, urine, albumen, infusion of raw meat, saliva, or isinglass, is placed on the leaf, the tentacles quickly bend inwards over the drop. DARWIn now set to work systematically to determine which salts and acids cause and which do not cause inflection. Of nine salts of ammonia tried, all caused inflection of the tentacles, and of these the phosphate of ammonia was the most powerful. Sodium salts in general cause inflection while potassium salts do not. The earthy salts are in general inoperative, as are likewise those of lead, manganese, and cobalt. The more or less poisonous salts of silver, mercury, gold, copper, nickel, platinum, and chromic and arsenious acids produce great inflection with extreme quickness. Other substances which caused inflection were nitric, hydrochloric, iodic, sulphuric, phosphoric, boracic, and many organic acids; gallic, tannic, tartaric, citric, and uric acids alone being inoperative. In all these cases, where a bending of the tentacles over the drop occurs, the turning must be regarded as a response to the stimulus of the chemical substance. An excitation proceeds from the irritated region to the protoplasm upon whose imbibitory activity the turning of the tentacles depends.

2. Chemotropism of Roots. - Attention was directed to the fact that roots turn towards or from chemical substances by MoLisch ('84), who experimented with gases. When grains of maize or peas are sprouted in water, their roots will turn

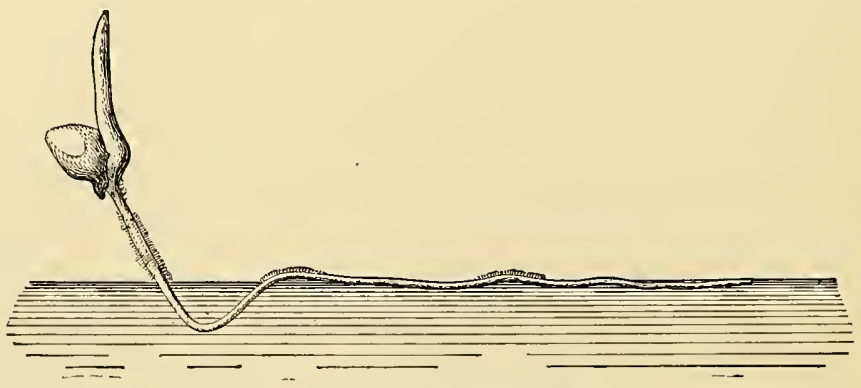

FIG. 91. - Seedling of Zea, whose radicle originally was just touching the water obliquely with its apex and thereafter nutated in characteristic fashion, keeping close to the air. (From MoLisch, '84.) 
upwards towards the surface of the water - in response to the more abundant oxygen supply there (Fig. 91), and will grow along the surface of the water. MoLisch undertook a systematic investigation of the action of various gases in controlling this growth.

The method employed was as follows: The gases were enclosed in glass vessels whose mouth was closed by a plate of hard rubber perforated by slits, $2 \mathrm{~cm}$. long by $2 \mathrm{~mm}$. broad. The vessel being laid on its side so that the slits were vertical, the rootlet of a germinating grain was placed in front of it. As the gas diffused from the ressel, it was for some time in excess upon one side of the rootlet. The gases experimented with were pure oxygen, pyrogallic acid, nitrogen, carbon dioxide, chlorine, hydrochloric acid gas, illuminating gas, ammonia, nitrous oxide, ether, chloroform, and oil of turpentine.

In all cases there occurred, generally after about an hour, a turning of the root towards the gas (positive aërotropism, MoLisch), followed by a marked curvature from the slit (negative aërotropism). Since decapitated roots respond in the same way as intact ones, but in less degree, MoLIsch concluded that the gases affect the growing region directly and do not require the intervention of the root-tip.

3. Chemotropism of Pollen-tubes. - The suggestion was early made by PFEFFER ('83), as a consequence of his discovery of chemotaxis in swarm-spores, that perhaps the bending of the antheridium-tube of Saprolegnia towards the oögonium was a case of response to a chemical agent. Strasburger ('86) offered a similar suggestion for phanerogams. Pferfer ('88) then made experiments, but was unable to control the direction of growth of pollen-tubes. MoLisch ('89 and '93) was next led to undertake further study in this direction by the observation that, when various pollen-grains are germinating in a nutritive drop and a cover-glass is placed over them, the pollentubes, after approaching near to the edge of the cover-glass, turn away towards the centre again (Fig. 92, $a, b$ ). The movement from the margin of the cover-glass cannot be ascribed to a difference of density produced by evaporation at the margin, for it occurred in a saturated atmosphere; nor can it be due to surface tension of the bounding film of water, for the turning occurred before the surface film was reached. These results 
were abundantly confirmed by Mryoshi (' $\left.94^{a}\right)$, so we must conclude that the pollen tube is negatively aerotropic to oxygen. However, this negative aërotropism does not occur in all pollen, for that of Orobus vernus and various other legumes, of Primula acaulis, Viola odorata, V. hirta, etc., were indifferent.

a
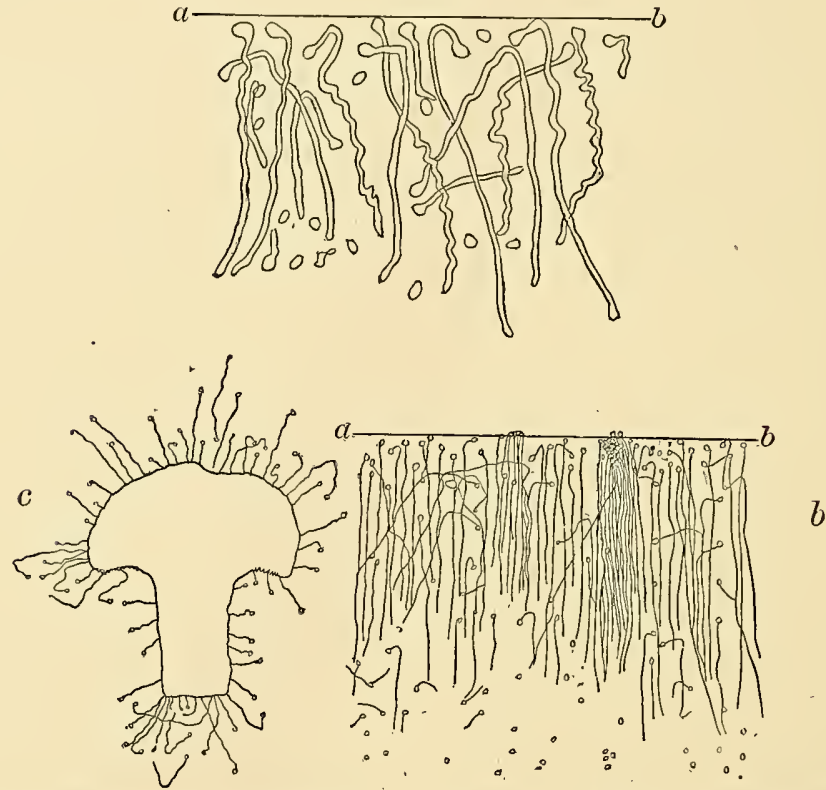

Fig. 92. - Illustrates chemotropism of pollen-tubes. $a$. Negative chemotropism with reference to the air (aërotropism) of pollen-tubes of Narcissus tazetta; the tubes are growing under a cover-glass in a $7 \%$ sugar solution and turn at the edge, $a, b$, from the air; magnified about 20. b. Negative aërotropism of pollen-tubes of Cephalanthera pallens, after 20 hours; $a, b$, edge of cover-glass. $c$. Stigma of Nareissus tazetta in $7 \%$ sugar solution; pollen-tubes grow towards the stigma; magnified about 10. (From Moursch, '93).

A second class of chemotropisms is seen in the turning of pollen-tubes towards the stigma of a flower.* When pollen is sown upon a plate of agar-agar or gelatine on which the upper end of a ripe pistil has been placed, the tubes are sent out in

* Molisch accounts for the failure of some of the earlier experiments with pollen-tubes on the ground that certain pollen-tubes do not exhibit this class of chemotropism. Among these are Viola odorata, V. hirta, Orobus vernus, etc. species which are likewise not aërotropic. 
all directions at first, but quickly grow towards the pistil (Fig. 92,c). Mrroshi ('94 $4^{\mathrm{a}}$ ) found that the top of the pistil was most attractive and that lower sections were less so until the ovary is nearly reached, when the attraction is high again. If the ovules of Scilla are placed on the plate of agar with its own pollen, the pollen-tube will even grow into the micropyle of the ovule. Pollen-tubes of a different species or even genus, e.g. Diervilla rosea, Ranunculus acer, etc., may likewise enter the Scilla ovule, and even hyphæ of Mucor stolonifer will turn towards the ovules and penetrate into them. Thus the attracting stuff is not a specific stimulant confined in its activity to one kind of pollen-tube nor even to pollen-tubes in general.

The nature of the attracting substance has been studied by Mryoshr. Glucose is certainly present in the fluid excreted by the ripe stigma of many phanerogams; and, if the agar-agar substratum contain a $2 \%$ solution of cane sugar, there is no longer chemotropism with reference to the orule, since now the attraction is not confined to a particular point. So it may be concluded that it is the sugar of the ovule or stigma which attracts the pollen-tube and that the excreted fluid contains about a $2 \%$ solution. Consequently, the chemotropism of pollen-tubes may be only a special case of chemotropism to sugar.

Further experimentation confirmed Mrroshr ('94) in this conclusion. Using the method employed by him in the case of hyphæ (p. 340), he injected Tradescantia leaves with various solutions and sowed pollen of Digitalis purpurea upon the leaves. When pure water was injected there was no effect, but the substances named in the following list attracted the pollen-tubes so that they grew down through the stomata into the leaf : -

$\begin{array}{llll}\text { cane sugar. } & 2-8 \% & \text { levulose } & 1 \% \text { (slight action) } \\ \text { grape sugar, } & 4-8 \% & \text { lactose . 1-2\% ("slight") } \\ \text { dextrin . . } & 1-2 \%\end{array}$

The following solutions were neutral :-

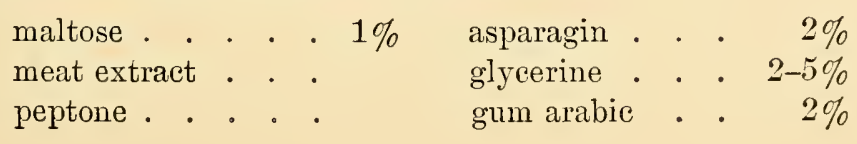


The following were repellent:-

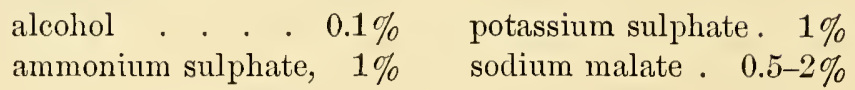

It will be observed that all the attracting substances are sugars.

4. Chemotropism of Hyphæ. - While various authors had noticed an apparent movement of hyphæ towards certain chemical agents or towards their hosts, the earliest systematic observations upon this subject are those of WORTMANN ('87). He placed fly-legs and other nutritive substances in Saprolegnia cultures and noticed that the hyphe left their original direc-

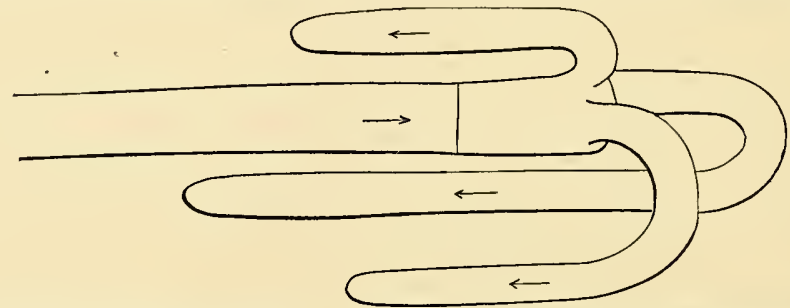

FIG. 93. - Negative chemotropism of a hypha of Peziza trifoliorum from the secretions of a mycelium of Aspergillus niger. (From ReINHARdT, '92.)

tions to grow straight towards the food substance. Later Reinhardt ('92) showed that hyphæ of Peziza may be lured out of their straight direction by spores of Mucor placed near them ; or, again, if a plate of gelatine rich in sugar be placed above a plate of pure gelatine upon which hyphæ of Peziza are growing, all hyphæ will send up branches to meet the more nutritive surface; or, again, if Aspergillus niger, whose secretions are fatal to Peziza, is placed near the latter, the hyphæ cease to grow at a distance of about $2 \mathrm{~mm}$. from the Aspergillus and then send out shoots which grow away from the injurious substance (Fig. 93).

The most exhaustive studies on this subject are, however, those of Mryoshi ('94), who worked with germinating spores of Mucor mucedo and M. stolonifer, Phycomyces nitens, Penicillium glaucum, Aspergillus niger, and Saprolegnia ferox. Perforated membranes were employed, either in the form of plant epidermis with stomata or of collodion films perforated 
by a fine needle point. The solutions were injected into the leaf of Tradescantia, spores were sown upon its stoma-bearing surface, and the whole was kept in a moist chamber. If the solution was attractive, the growing hyphre penetrated into the stomata, whereas in the absence of the solution they showed no tendency to do so. Similarly, spores sown on the perforated plate sent hyphæ downwards through the holes when the plate was floating on attractive solutions, but not otherwise. Mole-

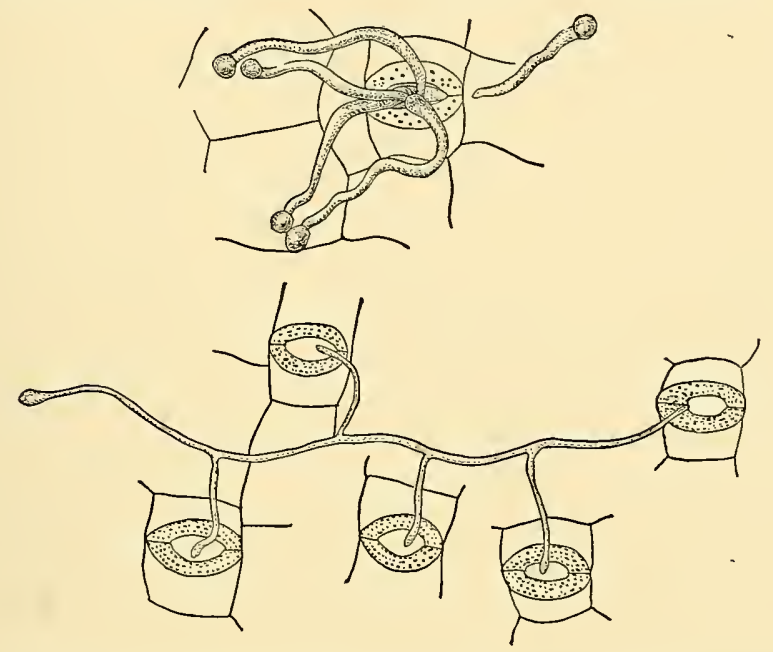

FIG. 94. - Upper figure: Piece of the under side of a leaf of Tradescantia discolor injected with $2 \%$ ammonium chloride, and sown with spores of Mucor stolonifer. The young hyphæ show chemotropic turnings, and have eventually penetrated into the stomata. Drawn 27 hours after sowing the spores; magnified 100. Lower figure: Penicillium glaucum growing on a leaf of Tradescantia, which has been injected with a $2 \%$ solution of cane sugar. The hyphæ have branched, and the branches have penetrated into the stomata. Drawn 25 hours after sowing the spores; magnified 70. (From Mryoshr, '94.)

cules diffusing out from the solution through the openings determine the direction of the growing hyphr, so that from all directions hyphæ grew radially towards the openings in the membranes (Fig. 94).

To prove that the result gained was truly chemotropism, and not something else, a series of experiments was made. That it was not a response to gravity was shown by sowing the spores below as well as on top of a leaf ; that it was not a response to light or moisture was shown by keeping the cult- 
ures in a dark, moist chamber ; in both cases, the chemotropic responses occurred. That contact was not the determining factor was shown by placing above and below sheets of perforated collodion a layer of $5 \%$ gelatine, deprived of calcium salts, which are attractive. One of these layers was fertilized with grape sugar, the other remained sterile. The spores were sown sometimes in the sterile, sometimes in the fertile layer of gelatine; in the former case, the hyphre always grew (up or down) into the sterile layer ; in the other case, they remained in the fertile layer. If both gelatine layers were sterile, or if both were equally fertile, the hyphæ did not grow through the holes in the membranes. Not the holes, but the stuff diffusing from them, determined the direction of growth of the hyphæ.

There is a close relation between the chemical constitution of the agents and their effects. The following substances are attractive: compounds of ammonium (ammonium nitrate, chloride, malate, tartrate), phosphates (of potassium, sodium, ammonium), meat extract, peptone, sugar, asparagin, lecithin, etc. The following are neutral: glycerine and gum arabic (1 to 2\%). The following are repellent: all free inorganic as well as organic acids, alkalis, alcohol, and certain salts, e.g. potassium-sodium tartrate, potassium nitrate, calcium nitrate, potassium chloride (2\%), potassium chlorate (8\%), magnesium sulphate, sodium chloride (2\%), ferric chloride $(0.1 \%)$, phosphoric acid, etc. Comparing this list with that which Pfefrer and Stange tried on swarm-spores (Pt. I, pp. 3638 ), we find that there is a rather close correlation. In both cases, glycerine (a good food) is neutral, alcohol repellent, phosphates attractive. As in the reaction of swarm-spores, so in those of hyphæ, WEBER's law is followed.

5. Chemotropism of Conjugation Tubes in Spirogyra. This case is closely allied to chemotropism of pollen-tubes. Attention was first called to it by Overton ('88), who observed that at the point where the tubes were about to arise bacteria accumulated from the surrounding water. From this phenomenon, and on other grounds, he was led to conclude that a substance is excreted at this point which exercises a directive influence upon the conjugation tubes, insuring their meeting. This conclusion has been confirmed by HABERLAND 
('90), who finds additional evidence for it in the character of the turnings which the two tubes from the opposite cells undergo in order successfully to impinge upon each other.

The results of experimentation upon chemotropism show that various substances may direct the growth of such elongated organs as the tendrils, roots, and hyphæ of plants; so that greater growth takes place on the side turned from the region of greatest concentration or towards it, as the case may be. In many instances it can be shown that the direction of growth is on the whole an advantageous one for the organism - so that the directed growth may be considered an adaptive one. In other cases, however, the response seems to have no relation to adaptation.

If that which controls direction is the unequal concentration of chemical agents in the medium, the immediate cause is excessive growth on one side, due to excessive imbibition or to excessive assimilative activity. The relation between these causes is doubtless complicated. The chemical agent acts upon the protoplasm, changing its molecular structure; the changed protoplasm exhibits changed growth activities. Thus we say the chemical agents act as stimuli.

\section{LITERATURE}

Aєвт, J. H. '96. Beitrag zur Frage der Stickstoffernährung der Pflanzen. Landwirthsch. Versuchs-Stat. XLVI, 409-439.

Aschoff, C. '90. Ueber die Bedeutung des Chlors in der Pflanze. Landw. Jahrbiicher. XVIII, 113-141.

Bässler, P. 'S7. Die Assimilation des Asparagins durch die Pflanze. Landwirthsch. Versuchs-Stat. XXXIII, 231-240.

Baumann, E. '95. Ueber das normale Vorkommen von Jod im Thier-

körper. (I. Mitth.) Zeitschr. f. physiol. Chemie. XXI, 319-330.

28 Dec. 1895.

Baumanx, E. and Roos, E. '96. Idem (II. Mitth.), ibidem. XXI, 481-493. 2 Apr. 1896.

Baumann, E. '96. Idem (III. Mitth.), ibidem. XXII, 1-15. 16 May, 1896. Benecke, W. '95. Die zur Ernährung der Schimmelpilze nothwendigen Metalle. Jahrb. f. wiss. Bot. XXVIII, 487-530.

'96. Die Bedeutung des Káliums und des Magnesiums für Entwickelung und Wachsthum des Aspergillus niger v. Th., sowie Einiger andererPilzformen. Bot. Ztg. LIV. 
Berthelot, '85. Fixation directe de l'azote atmosphérique libre par certains terrains argilenx. Comp. Rend. CI, 775-784. 26 Oct. 1885.

'92. Nouvelles recherches sur la fixation de l'azote atmosphérique par les microbes. Comp. Rend. CXV, 569-574. 24 Oct. 1892.

'93. Recherches nouvelles sur les nicroorganismes fixateurs de l'azote. Comp. Rend. CXVI, 812-819. 24 Apr. 1893.

Bert, P. '7S. La pression barométrique. Recherches de physiologie experimentale. 1168 pp. Paris, 1878.

Beýrinck, M. W. '93. Bericht über meine Kulturen niederer Algen auf

Nährgelatine. Centralbl. f. Bakteriol. u. Parasitenkunde. XIII, 368373. 23 Mar. 1893.

'96. Kulturversuche mit Amöben auf festem Substrate. Centralb]. f. Bakteriol. u. Parasitenk. XIX, 257-267. 28 Feb. 1896.

Bezold, A. von ' 57 . (See Chapter I, Literature.)

Boкorny, T. '97. Ueber die organische Ernährung grüner Pflanzen und ihre Bedeutung in der Natur. Biol. Centralbl. XVII, 1-20; 33-48. Jan. 1897.

Boussingault, J. B. J. D. '60. Agronomie, chemie agricole et physiologie. 2 tomes. Paris, Mallet-Machelier, 1860.

Brande, J., and TAppenmer, H. '92. Ueber die Ablagerung von Fluorverbindung im Organismus nach Fütterung mit Fluornatrium. Ztschr. f. Biol. XXVIII, 518-539.

Bunge, G. '73. Ueber die Bedeutung des Kochsalzes und des Verhalten der Kalisalze im menschlichen Organismus. Ztschr. f. Biol. IX, 104-143.

'74. Der Kali-, Natron-, und Chlorgehalt der Milch, verglichen mit dem anderer Nährungsmittel und das Gesammt-Organismus der Saugethiere. Ztschr. f. Biol. X, 295-335.

'S5. Ueber die Assimilation des Eisens. Ztschr. f. physiol. Chem. IX, 49-59.

'89. Ueber die Aufnahme des Eisens in den Organismus des Sauglings. Ztschr. f. physiol. Chem. XIII, 399-406.

Celli, A. '96. Die Kultur der Amöben auf festem Substrate. Centralbl. f. Bakteriol. XIX, 536-538. 25 Apr. 1896.

Copeland, E. B. '97. The Relation of Nutrient Salts to Turgor. Bot. Gazette. XXIV, 399-416. Dec. 1897.

Cook, G. H. '68. Geology of New Jersey. Newark, 1868.

Crivelli, G. B. and MaGGI, L. '70. Sulla produzione delle Amibe. Rend.

R. Inst. Lombardo. (2), III, 367-375. Plate.

'91. Ancora sulla produzione delle Amibe. Ibidem. (2), IV, 198-203.

Danilewsiry, B. '95. De l'influence de la lécithine sur la croissance et la multiplication des organismes. Comp. Rend. CXXI, 1167-1170. 30 Dec. 1895.

'96. De l'influence de la lécithine sur la croissance des animaux à sang' chaud. Comp. Rend. CXXIII, 195-198. 20 July, 1896.

DArwin, C. '75. Insectivorous Plants. London: Murray. 462 pp. 1575.

DAY, T. C. '94. The Non-Assimilation of Atmospheric Nitrogen by Germinating Barley. Trans. and Proc. Bot. Soc. Edinburgh. XX, 29-34. 
Duclaux, E. '89. Sur la nutrition intracellulaire. Ann. de l'Inst. Pasteur. III, 97-112. March, 1889.

Eschle '97. Ueber den Jodgehalt einiger Algenarten. Zeitschr. f. physiol. Chemie. XXIII, 30-37. 27 Mar. 1897.

Forchнамmer, G. '61. Resultatel' af sine Undersogelser, saavel over Saltmængden i Middelhavets Vand. Overs. K. danske Vidensk Selskabs Forhangl. Aaret. 1861. 379-391.

Fraxk, A. B. 'ss. Die Ernahrung der Pflanzen mit Stickstoff. Berlin, 1888. '92. Lehrbuch der Botanik, I. 669 pp. Leipzig: ExGELmans.

'93. Die Assimilation des freien Stickstoffs durch die Pflanzenwelt. Bot. Ztg. LI, 139-156.

Frederice, L. '78. Sur l'organisation et la physiologie du Poulpe. Bull. de l'Acad. roy. de Belg. XLVI, 710-765.

'79. Note sur le sang du Homard. Ibid. XLVII, 409-413.

Gorinı, C. '96. Die Kultur der Amöben auf festem Substrate. Centralbl. f. Bakteriol. XIX, 785 .

Haberland, G. '90. Zur Kenntnis der Conjugation bei Spirogyra. Sitzungsber. d. Akad. d. wiss. Wien. Math.-Nat. Cl. XCIX', 390-400. 1 Tafel.

Hansteen, B. '96. Beiträge zur Kenntniss der Eiweissbildung' und der Bedingungen der Realisirung dieses Processes im phanerogamen Pflanzenkörper. Ber. dentsch bot. Ges. XIV, 362-371. 28 Dec. 1896.

Hartig, R. and Weber, R. '\$8. Das Holz der Rotbuche. Berlin, 1888. [Quoted from Loew, '91, p. 270.]

Hellriegle, H. '86. Welche Stickstoffquellen stehen der Pflanze zu Gebote? Tageblatt des 59. Versammelung, Deutscher Naturforscher und Aerzte. Berlin, 1886. p. 290.

Hensen, V. and Apsteen, C. '97. Die Nordsee-Expedition, 1895, des Deutschen Seefischerei-Vereins. Ueber die Eimenge der im Winter laichenden Fische. Wiss. Meeresuntersuchungen, herausgegeben von der Kommission zur wiss. Unters. d. deutschen Meere in Keil, N. F. Band II, Heft. 2, pp. 1-9S.

Herbst, C. '97. Ueber die zur Entwickelung der Seeigellarven nothwendigen anorganischen Stoffe, ihre Rolle und ihre Vertretbarkeit, I. Theil. Die zur Entwickelung nothwendigen anorganischen Stoffe. Arch. f. Entwickelungsmechanik d. Organismen. V. 649-793. Taf. XII-XIV. 9 Nor. 1897.

Heraeus '86. Zeitschr. f. Hygiene. I.

Hoppe-Seyler, F. ' $\$ 1$. Physiologische Chemie. Berlin, 1881.

Hotter, E. '90. Ueber das Vorkommen des Bor im Pflanzenreich und dessen physiologische Bedentung. Landw. Versuchs-Station. XXXVII, 437-458. 1890.

JACCARD, P. '93. Influence de la pression des gaz sur le développement des vegetaux. Comp. Rend. CXVI, 830-S33. 17 April, 1893.

JENTYS, S. '88. Ueber den Einfluss hoher Sauerstoffpressungen auf das Wachsthum der Pflanzen. Unters. a. d. bot. Inst. Tübingen. II. $419-464$. 
Johnson, S. W. '68. How Crops grow. 394 pp. New York.

Jordan, E. O. and Richards, E. '91. Investigations upon Nitrification and the Nitrifying Organism. From Report, Mass. State Board of Health, Water Supply, and Sewage. Part II. pp. 865-881. [Dated 1890.]

Kemierich, E. '69. Untersuchungen über die physiologische Wirkung der Fleischbrühe, des Fleischextracts und der Kalisalze des Fleisches. Arch. f. d. ges. Physiol. II, 49-93.

Косн, А. and Kossowrsch, P. '93. Ueber die Assimilation von freiem Stickstoff durch Algen. Bot. Ztg. LI, 321-325. Nov. 1, 1893.

Kossowitscir, P. '94. Untersuchungen über die Frage, ob die Algen freien Stickstoff fixiren. Bot. Ztg. LII, 97-116. 16 May, 1894.

Krukenberg, C. F. W. '80. (See Chapter II, Literature.)

78. Mangan ohne nachweisbare Mengen von Eisen in der concretionen ans dem Bojanus'schen Organe im Pinna squamosa Gm. Unters. Physiol. Inst. Univ. Heidelberg. II, 287-289.

Kunnel, A. J. '91. Zur Frage der Eisenresorption. Arch. f. d. ges. Physiol. L, 1-24. 25 June, 1891.

'95. Blutbildung aus anorganischen Eisen. Arch. f. d. ges. Physiol. LXI, 595-606. 25 Sept. 1895.

Laurext, E. '88. Sur la formation d'amidon dans les plantes. Bruxelles, 1885.

Lawes, J. B. and Gilbert, J. II. '53. On the Composition of Foods, in Relation to Respiration and the Feeding of Animals. Rept. 22d Neet. British Ass. Adv. Sci. for 1852, 323-353.

Lawes, J. B., Gilbert, J. H. and Pugh, E. '61. On the Sources of the Nitrogen of Vegetation, with Special Reference to the Question whether Plants assimilate Free or Uncombined Nitrogen. Philos. Trans. Roy. Soc. London. CLI, 431-577.

Liebscher '93. Beitrag zur' Stickstofffrage. Jour. f. Landwirtschaft. XLI. [not seen.]

Loeb, J. '92.' (See Chapter' X, Literature.)

Loww, O. '91. Die chemische Verhältnisse des Bakterienlebens. Centralbl.

f. Bakteriol. IX, 659-663.

'91'. Ueber die physiologischen Functionen der Phosphorsäure. Biol. Centralbl. XI, 269-281. 1 June, 1891.

'96. The Energy of the Living Substance. 116 pp. London. 1896.

Loew, O. and Boronvy, T. 'S7. Chemisch-physiologische Studien über Algen. Jour. f. prakt. Chem. XXXVI, 272-291.

Lüpke, R. '89. Ueber die Bedeutung des Kaliums in der Pflanze. Landw. Jührb. XVII, 887-913.

Macallum, A. B. '91. On the Demonstration of the Presence of Iron in Chromatin by Micro-chemical Methods (Abstract). Proc. Roy. Soc. XLIX, 488-489. July 10, 1891.

'92. Idem. Proc. Roy. Soc. XL, 277-286. Jan. 20, 1892.

'94. On the Absorption of Iron in the Animal Body. Jour. of Physiol. XVI, 268-297. 17 April, 1894. 
Meyer, A. '85. Ueber die Assimilations-producte der Laubblätter angiospermer Pflanzen. Bot. Ztg. XLIII, 417 et seq.

Mrrosni, C. '94. Ueber Chemotropismus der Pilze. Bot. Ztg. LII, 1-27. 1 Taf.

'94. Ueber Reizbewegungen der Pollenschläuche. Flora. LXXVIII, 76-93. 24 Jan. 1894.

MoLısci, H. '8t. Ueber die Ablenkung der Wurzeln von ihrer normalen Wachsthumsrichtung durch Gase (Aërotropismus). Sb. k. Akad. d. Wiss. Wien. XC1, 111-191.

'89. Ueber die Ursachen der Wachisthumsrichtungen bei Pollenschläuchen. Sitzungsanzeiger k. Akad. Wiss. Wien. 1889, No. II.

'92. Die Pflanze in ihren Beziehungen zum Eisen. Jena, 1892.

'93. Zur Physiologie des Pollens, mit besonderer Riicksicht auf die chemotropischen Bewegungen der Pollenschlänche. Sb. k. Akad. d. Wiss. Wien. CII $1,423-448$.

'94'. Ueber Chemotropisnus der Pilze. Bot. Ztg. LII ${ }^{1}, 1-27$.

'9.'b Ueber Reizbewegung der Pollenschläuche. Flora. LXXVIII, 76-93. 24 Feb. 1894.

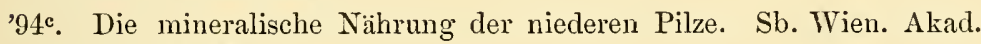
CIII ${ }^{1}, 554-574$.

'95. Die Ernährung der Algen. Süsswasser Algen. I. Abhandl. Sb. Akad. Wiss. Wien. CIV $1,783-800$.

'96. The same. II. Abhandlung. Sb. Akad. Wiss. Wien. CV1, pp. 633-648.

Montr, R. '95. Sur les cultures des amibes. Arch. Ital. de Biol. XXIV, $174-176$.

NägELI, K. v. [with Loew, O.]. '80. Emährung der niederen Pilze durch Kohlenstoff- und Stickstoffverbindungen. Sb. München Akad. X, $277-367$.

Nexcki, M. '94. Note sur les prétendues cendres des corps albumenoïdes. Arch. des sci. biol. St. Petersburg. III, 212-215.

Nencki, M. and Schoumow-Simanowskx, E. O. '94. Études sur le chlore et les lalogènes dans l'organisme animale. Arch. des sci. biol. St. Petersburg. III, 191-211.

Nobbe, F., Schroder, J. and Erduann, R. '71. Ueber die organische Leistung der Kaliums in der Pflanze. Landw. Versuchs-Stat. XIII, $321-399 ; 401-423$.

Nobie, F. and Hiltwer, L. '95. Vermögen auch Nichtlegumenosen freier Stickstoff aufzunehmen? Landw. Versuchs-Stat. XLV. 155-159.

Ogata, M. '93. Ueber die Reinkultur gewisser Protozoen (Infusorien). Centralbl. f. Bakteriol. XIV, 165-169. 7 Aug. 1893.

Overton, C. E. '88. Ueber den Conjugationsvorgang bei Spirogyra. Ber. D. bot. Ges. VI, $68-72$.

Petermann, A. '91. Contribution à la question de l'azote. Première note. Mém. cour. et antres mém. de l'acad. Roy. de Belg. Collection in 8vo. XLIV. 23 pp. 1 pl. Jan. 1891.

'92. Seconde note. Same Mémoires. XLVII, 1-37, 1 pl. 
P'Feffer, W. 'S3. (See Chapter I, Literature.)

's8. Ueber chemotactische Bewegungen von Bakterien, Flagellaten und Volvocineen. Unters. a. d. bot. Inst. Tübingen, II. 582-661.

'95. Ueber Ėlection organischer Nährstoffe. Jahrb. f. wiss. Bot. XXVIII, $205-268$.

Pfemferi, T. and Franke, E. '96. Beitrag zur Frage der Verwertung elementaren Stickstoffs durch den Senf. Landw. Versuchs-Stat. XLVI, 117-151. Taf. I.

Poleck, T. '50. Analyse der Asche von Eiweiss und Eigelb der IIühnereier. Ann. de Physik und Chemie. LXXVI, 155-161. 7 Feb. 1850.

Presch, W. '90. Ueber das Verhalten des Schwefels im Organismus und den Nachweis der unterschwefligen Säure im Menschenharn. Arch. f. path. Anat. u. Physiol. CXIX, 148-167. 2 Jan. 1890.

Pröscuer '97. Die Beziehungen der Wachsthumsgeschwindigkeit des Säuglings zur Zusammensetzung der Milch bei verscheidenen Sangethieren. Zeitschr. f. physiol. Chem. XXIV, 285-302. 22 Dec. 1897.

Puriewitscir, K. '95. Ueber die Stickstoffassimilation bei den Schimmelpilzen. Ber. D. bot. Ges. XIII, 342-345. 27 Nov. 1895.

Rauber, A. '84. Ueber den Einfluss der Temperatur, des atmosphärischen Druckes und verschiedener Stoffe auf die Entwicklung thierischer Eier. Sitzungsber. d. naturf. Gesell. Leipzig. X, 55-70.

Raulin, J. '69. Etudes chimiques sur la végétation. Ann. des Sci. Nat. (Bot.). (5), XI, 93-299.

Rernhard', M. O. '92. Das Wachsthum der Pilzhyphen. Jahrb. f. wiss. Bot. XXIII, 479-599.

Richarns, H. M. '97. Die Beeinflussung des Wachsthums einiger Pilze durch chemische Reize. Jahrb. f. wiss. Bot. XXX, 665-688.

Roos, E. '96. Ueber die Wirkung der Thyrojodins. Zeitsehr. f. physiol. Chem. XXII, 16-61. 16 May, 1896.

SAcrs, J. v. '87. Vorlesungen iiber Pflanzenphysiologie. Leipzig, Engelmann. Sснгмper, A. F. IV. '90. Zur Frage der Assimilation der Mineralsalze durch die grüne Pflanze. Flora. LXXIII, 207-261.

Schiösing, T. fils et Laurent, E. '92. Recherches sur la fixation de l'azote libre par les plantes. An1. de l'Inst. Pasteur. VI, 65-115. Feb. 1892.

'92. Sur la fixation de l'azote libre par les plantes. Ann. de l'Inst. Pasteur. VI, 824-840. Dec. 1892.

Schlesing, T., and MüNtz, A. '77. Sur la nitrification par les ferments organisés. Comp. Rend. LXXXIV, 301-303. 12 Feb. 1877.

79. Recherches sur la nitrification. Comp. Rend. LXXXIX, 891-894. 24 Nov. 1879.

Schneider, R. '89. Verbreitung und Bedentung des Eisens im animalisehen Organismus. Humbolt. VIII, 337-345. Sept. 1889.

'95. Die neuesten Beobachtungen iiber naturliche Eisenresorption in thierischen Zellkernen und einige charakteristische Fälle der Fisenverwerthung im Körper von Gephyreen. Mitth. a. d. Zool. Stat. zu Neapel. XII, 208-215. 6 July, 1895. 
Schulz, H. '88. Ueber Hefegifte. Arch. f. ges. Physiol. XLII, 517-541. 20 March, 1888.

'93. Ueber den Schwefelgehalt meuschlicher und thierischer Gewebe. Arch. f. d. ges. Physiol. LIV, 555-573. 7 July, 1893.

Socın, C. A. '91. In welcher Form wird das Eisen resorbirt? Zeitschr. f. physiol. Chem. XV, 93-193. 10 Jan. 1891.

Stoklasa, J. '96. Studien über die Assimilation elementaren Stickstoffs durch die Pflanze. Landw. Jahrb. XXIV, 827-863.

Strasburger, E. 'S6. Ueber fremdartige Bestaubung. Jahrb. f. wiss. Bot. XVII, 50-98.

Tammann, G. '88. Ueber das Vorkommen des Fluors in Organismen. Zeitschr. f. physiol. Chem. XII, 322-326.

Tappeiner, H. '93. Ueber Ablagerung vou Fluorsalzen im Organisnums nach Futterung mit Fluoruatrium. Sb. Ges. Morph. u. Physiol. Munchen. VIII, 22-26.

Townsend, C. O. '97. The Correlation of Growth under the Influence of Injuries. Ann. of Bot. XI, 509-532.

Vines, S. H. '86. (See Chapter VIII, Literature.)

Volkmans, A. W. '74. Untersuchungen über das Mengenverhältniss des Wassers und der Grundstoffe des menschlichen Körpers. Ber. d. Sächs. Ges. d. Wiss., Leipzig. XXVI, 202-247.

Wieler, A. '83. Die Beeinflussung des Wachsens durch verminderte Partiärpressung des Sauerstoffs. Unters. a. d. bot. Inst. Tübingen. I, 189-232.

Winogradsiry, S. 'S4. Ueber die Wirkung äusserer Einflüsse auf die Entwicklung von Mycoderma vini. Arb. St. Petersburger Naturf. Ges. XIV, 132-135 [Russian]. Abstr. in Bot. Centralbl. XX, 165-167.

'87. Ueber Schwefelbacterien. Bot. Ztg. XLV, 493 et seq.

'89. Recherches physiologiques sur les sulphobactéries. Ann. l'Inst. Pasteur. III, 49-60. Feb. 1887.

90. Recherches sur les organismes de la nitrification. Ann. l'Inst. Pasteur. IV, 257-275. May, 1890.

'95. Recherches sur l'assimilation de l'azote libre de l'atmosphère par les microbes. Arch. des sci. biol. de St. Petersb. III, 297-352.

Wolff, E. v. 'S1. Ueber die Bedentung der Kieselsäure für die Haferpflanze Landw. Versuchs-Stat. XXVI, 415-417.

'65. Mittlere Zusammensetzung der Asche, aller land- und forstwirthschaftlichen wichtigen Stoffe. Stuttgart, 1865.

Woltering, H. W. F. C. '95. Ueber die Resorbbarkeit der Eisensalze. Zeitschr. f. physiol. Chem. XXI, 186-233. 26 Nov. 1895.

Wortmann, J. 's7. Zur Kenntniss der Reizbewegung. Bot. Ztg. S12.

YUnG, É. 'S3. Contributions à l'histoire de l'influence des milieux physicochimiques sur les êtres vivants. Arch. de Zool. (2). I, 31-52. 


\section{CHAPTER XII}

\section{THE EFFECT OF WATER UPON GROWTH}

WE have already, in Chapter $\mathrm{X}$, laid stress upon the importance of the imbibition of water for the growth of both plants and animals. Here we may consider more in detail the relation between growth and water, both as concerns the rate or quantity of growth and the direction of growth, or hydrotropism.

\section{§ 1. Effect of Water upon the Rate AND Quantity of Growth}

It naturally follows from what we know of the importance of water for growth, that the rate of growth will be closely dependent upon water supply. And as all growth-phenomena have been better studied in plants than in animals, our further illustration of this fact will be drawn chiefly from the former.

First, plant germination demands a certain minimal quantity of water. What this quantity is may be determined either by finding the least amount which will permit of normal germination, or by measuring the amount absorbed by different seeds before protruding their radicles. This latter quantity has been shown by the careful determinations of HoFFuann ('65, p. 52) to vary from between $40 \%$ and $60 \%$ of the original dry weight, in the case of various cultivated grains, to over $100 \%$ in the case of various Leguminosæ.

In fungi, likewise, Lesage ('95, p. 311) has found that there is a hygrometric limit below which Penicillium spores will not germinate; and that the interval elapsing before germination begins is the shorter the moister the atmosphere.

The method employed by Lesage is of wide applicability. The tension of the water-vapor formed above a saline solution is less than that formed above distilled water; and it diminishes in proportion to the concentration 
of the solution. Indeed, to a given solution of a particular salt, e.g. sodium chloride, there corresponds a constant hygrometric state, however much the temperature may vary. This hygrometric condition may be calculated by the formula : $1-n a$, where saturation is taken as unity, $n$ equals the number of grammes of sodium chloride dissolved in 100 grammes of water, and $a$ is a constant factor, varying with the salt, and equal to 0.00601 in the case of sodium chloride. The spores were reared in a moist chamber, whose bottom was made by a plate full of the solution.

The results of LESAGE's experiments are given in the following table :-

\section{TABLE XXXVI}

Showivg Interval in Dats elapsivg before Germination when Spores of Penicillium are kept in Moist Chambers over Various Solutions of Sodiua Chloride

\begin{tabular}{|c|c|c|c|c|c|}
\hline $\mathbf{n}$ & $\mathbf{0}$ & 21.5 & 23.5 & $\mathbf{2 6 . 5}$ & $30-33.5$ \\
\hline Interval . . . & 1 & 6 & 9 & 11 & No germination after 171 days \\
\hline
\end{tabular}

From these results it follows by calculation that the spores germinate at the hygroscopic state of $0.82-0.84$ or over, but not below this limit.

The foregoing cases, taken from the two principal groups of plants, agree in showing that a certain amount of water is essential to the revival of the metabolic activities which are preliminary to germination. The large quantity of water absorbed by the seed or spore affords the mechanism or the stimulus to growth.

Also, in the later stages of plant growth, the water both of the atmosphere and of the soil is essential. The importance of atmospheric moisture was shown by ReINkE ('T6), who compared the size of the leaf-stem in different hygrometric conditions.

The method of measuring was as follows: a young potted Datura (one of the Solanacex) was placed so that the lower half of one of its stems was horizontal. A fine platinum wire, suspended from a standard above, hung vertically near the stem, and made one turn around it. The lower end of the wire carried a 2-gramme weight. That part of the wire which surrounded the stem was protected by a layer of tinfoil. As the stem swelled or grew thimner, the weight rose or fell. The vertical oscillation of the weight measured the variation in circumference of the stem. 
It appeared that as the atmospheric moisture increased, a considerable increase in the cross-section of the stem followed; and as it diminished, the size of the stem diminished likewise. The results are graphically given in Fig. 95 .

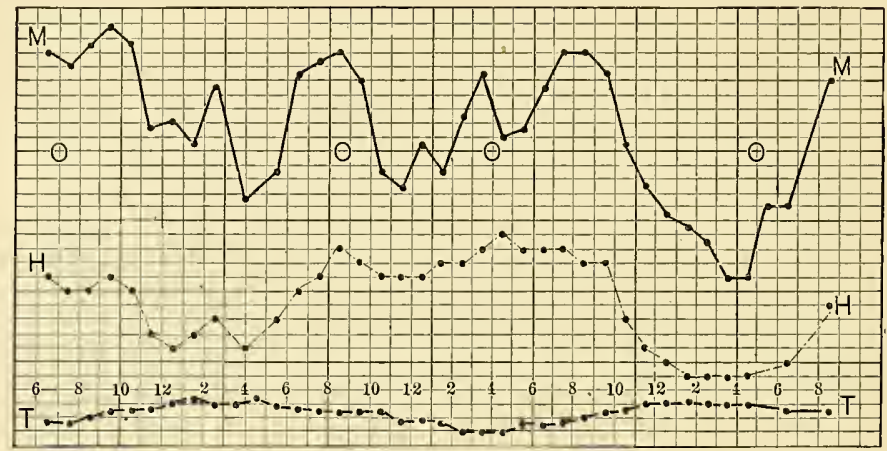

Fig. 95. - Curve of growth in thickness of a Datnra stem, $M-M$, correlated with variations in relative humidity, $H-H$, the temperature $T-T$ remaining nearly uniform. The part of the curve falling below $O-O$ indicates loss of thickness below the normal. The abscissæ represent hours. (From Reinise, 76.)

These experiments have been repeated by Francis DARIviN (93) upon the fruit of a gourd, Cucurbita, whose growth is little influenced by variations in temperature. He determined, by means of a delicate micrometer apparatus, the average increment in microns per minute; and, at the same time, by means of a dewpoint thermometer, the moisture of the air. The relation between rate of growth and psychometric readings is best shown graphically, as in the curves of Fig. 96. The

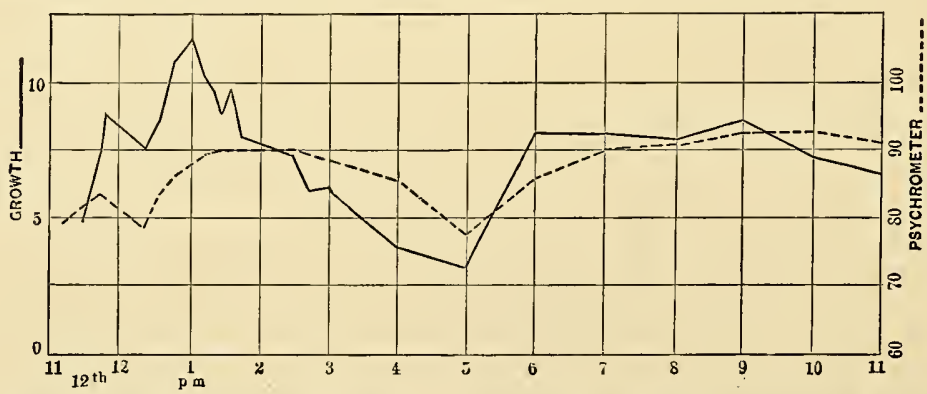

Fig. 96. - Curve of diameter of fruit of Cucurbita (full line) correlated with variation in humidity (broken line). The abscissæ represent hours; the ordinates represent growth in $\mu$ per minute (numbers on the left) and per cents of humidity (numbers on the right). (From DARwin, '93). 
figure shows plainly how, in general, an increment or a decrement in one of these quantities is accompanied by a corresponding change in the other.

The cause of this relation between changes in volume and in moisture is partially explained by considering the quickness with which increased growth follows increased moisture. It is undoubtedly due, as TschAPLowitz ('86) has suggested, to the diminution in the transpiration of the plant in moist air as compared with dry air. The change in the rate of transpiration is, however, not to be conceived as an immediate physical result of the change in moisture, but as a response to the stimulus of greater or less water in the atmosphere.

The amount of water in the soil also has an important influence on the rate of growth. Quantitative studies on this wellknown fact were afforded by HeLLrieged, who reared barley in soils which contained various fractional parts of the saturation quantity. Giving his results in the form. of a table, we have the following relation between the humidity of the soil and the amount of dry matter produced, after a certain number of days, in the grain and in the chaff :-

TABLE XXXVII

\begin{tabular}{c|c|c}
\hline \multirow{2}{*}{ HuMidity of SolL. } & \multicolumn{2}{|c}{ Production, ix Dry Matter. } \\
\cline { 2 - 3 } & Grains. & Chaff. \\
\hline $80 \%$ & 8.77 & 9.47 \\
60 & 9.96 & 11.00 (Max.) \\
40 & 10.51 (Max.) & 9.64 \\
30 & 9.73 & 8.20 \\
20 & 7.75 & 5.50 \\
10 & 0.72 & 1.80 \\
5 & - & 0.12 \\
\hline \hline
\end{tabular}

The principal conclusion that one can draw from this table is that there is an optimum humidity of the soil for growth, which is not, however, the same for all organs.

More extensive researches upon this subject have been made by Jumelle ('89), who studied chiefly the effect of water upon the growth of the various organs of the plant, and by $2 \mathrm{~A}$ 
Garn ('92, '95), who studied the effect upon the entire plant, so that his results are of especial interest here.

GaIN planted seeds of various species in sand to which a little garden loam had been added. He was careful either to select seeds of equal size or, after sprouting had occurred, to weed out all but the normal, medium-sized ones. In one set of experiments, the soil contained from $3 \%$ to $6 \%$ of water; in the other, from $12 \%$ to $16 \%$.

GAIN found that the entire plant grew faster in the humid than in the dry soil, as the accompanying diagram, Fig. 97,

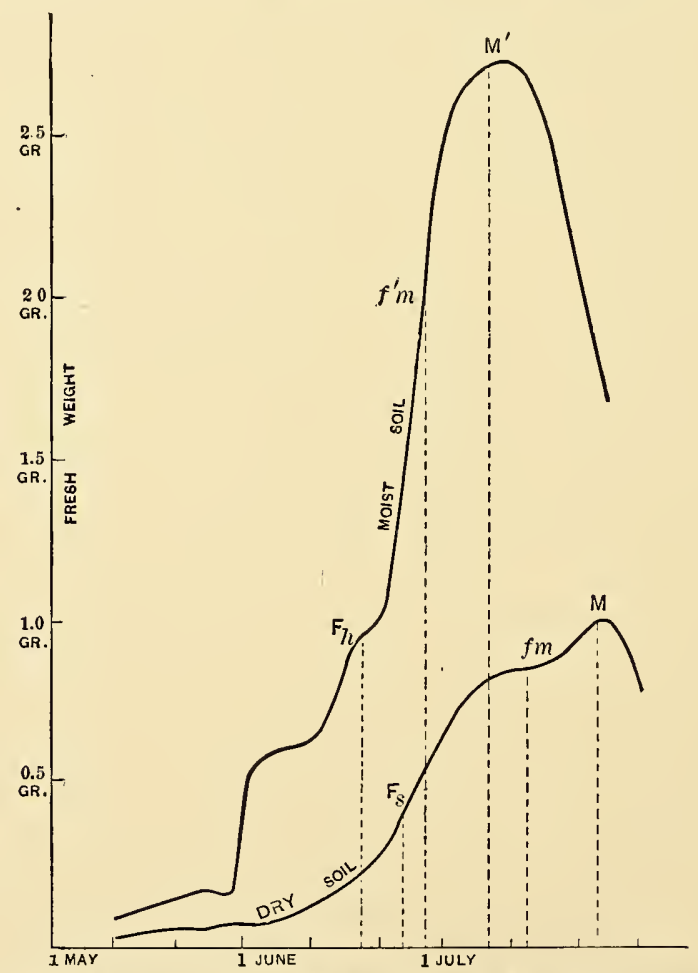

FIG. 97. - Curves of fresh weight of two similar seedlings of flax, one growing in moist, the other in dry, soil. The maximum weight $(M)$ gained by the plant differs in the two cases, and also the time of gaining that weight. $F$, time of flowering; $f m$, time of fructification. (From GaIN, '95.)

indicates. The aërial parts of the plant are more affected than the subterranean. The ratio of growth of plants in moist soil to those in dry varied from 1.12 (radish) to 2.33 (bean). 
Among animals the importance of moisture for the growing young is indicated by the fact that even in species living on the land or in the air the eggs and larvæ are frequently confined to moist situations, as in pulmonate gasteropods, in many insects, and in reptiles. When this is not the case, the eggs are provided with thick, water-containing envelopes, as in birds, or are placed on succulent leaves, or in special fluidfilled receptacles, as in many insects. Only rarely, as for example in the case of the meal worm, Tenebrio, and the Dermestidx, are the young found growing in a very dry medium. Doubtless in such cases the amount of water required for growth is less than in the cases where the larvæ develop in moist situations.

To summarize, a minimal quantity of water is essential to germination and growth; and above this limit growth proceeds more rapidly with the increase in water up to a maximum which varies with the species.

\section{§ 2. Effect of Water on the Direction of Growth - HYDROTROPISM}

A growing organ, such as a leaf, root, or stolon, is normally in a condition of turgescence, as a consequence of the imbibition of water. So long as the turgidity is equal on the two sides of the organ the latter retains its normal position. If the turgidity is diminished on one side, the organ bends towards that side; if it is increased on one side, the organ bends from that side. Thus, variations in cell turgidity cause changes in the position of organs.

This inequality of turgescence on the two sides of an organ may arise in a homogeneous atmosphere; for certain organs have the capacity in a dry atmosphere of losing water on one side faster than on the other, and in a moist atmosphere of becoming more turgescent on one side than on the other. Consequently, the organ assumes a characteristic position according as the hygroscopic condition of the atmosphere is high or low. Such hygroscopic movements are of wide occurrence among plants, and are often highly adaptive. We see them, for example, in the folding of vegetative parts of the so-called Resurrection Plant of California (Selaginella lepidophylla), by 
which the whole plant is rolled into a ball capable of being transported by the wind, perchance to a moister region. These hygroscopic movements occurring in a homogeneous medium are to be distinguished from true hydrotropism, for they are not properly growth phenomena.

True hydrotropism occurs in growing elongated organs, such as roots or stolons, which grow from or toward a region of greater or less moisture. The observations on this phenomenon have not been numerous, and are difficult to bring under one point of view ; consequently, we shall do best to classify the cases studied on the basis of the organs considered.

1. Roots. - The first studies upon hydrotropism in roots were made in the middle of the eighteenth century; but they were crude and uncritical. The first adequate experiments were made by KNight ('11). He half-buried some beans in a flower-pot filled with earth, inverted the pot (in which the earth and seeds were retained by a grating), and kept the earth moist by adding water through the hole in the bottom of the pot. The radicles, instead of growing vertically downwards as radicles normally do, ran horizontally along the surface of the moist earth. ' The same results were got by JoHNson ('29), who found in addition that if the mouth of the inverted flower-pot, or other seed receptacle, be placed in a moist atmosphere, the roots grow vertically downwards; they are no longer turned aside by dry air. Then Duchartre ('56) discovered that when a seedling was grown in relatively dry earth, with its aërial part in a close, moist chamber, the roots did not penetrate vertically into the soil, but grew out horizontally, and even upwards. SAcHs ('72) varied this experiment by planting his seeds in a basket made of netting, fixed to a metallic frame, and hung with its sides inclined at an angle of $45^{\circ}$ with the horizontal plane. When the apparatus was placed in a damp chamber the radicles grew vertically downwards; but in dry air they turned back towards the bottom of the sieve containing the damp earth, and ran along its under surface. SACHs called especial attention to the fact that it is the damper side which becomes concave; and this shows that the turning is not due to direct physical causes.

The second epoch in the study of hydrotropism now began. 
The fact of its existence being granted, the conditions of its occurrence were carefully studied. Thus Darwin ('80, Chapter III) investigated the locus of the irritable protoplasm. Some of the young bean-radicles were coated for the distance of a millimetre or two from the apex with a mixture of olive oil and lamp black in order to exclude the moist air. Such showed almost no hydrotropic movements. Killing the tip by caustic produced the same result. Thus the terminal two millimetres or so include the irritable protoplasm.

This conclusion was disputed by Wresser ('81, p. 133) and Detlefser ('82) on the grounds that on the one hand coating or killing the tip introduced abnormal conditions to which the failure of hydrotropism might be ascribed, and, on the other hand, after the tip of the root was cut off a eurving might still occur. However, a very careful review of the subject with new experiments by MoLisch ('84), a pupil of Wiesner, confirmed DARIvin's conclusion. Thus MoLisch covered all of the radicle excepting the terminal 1 to $1.5 \mathrm{~mm}$. with wet paper. This upper part could then hardly be irritated by an unequal distribution of moisture in the environment. Nevertheless, when a strip of moist filter-paper was placed opposite the tip the hydrotropic response occurred. The response must then have been due to a stimulus received exclusively at the tip, and it may be concluded that the tip alone is stimulated by moisture.

Now, although only a millimetre or two of the tip is irritable, the response of bending takes place some distance, 7 to $28 \mathrm{~mm}$., behind the tip, nearly in the region of maximum growth. Thus sensitive and responsive regions do not coincide - there is a transmission of stimuli. The facts that the hydrotropic response occurs in the region of rapid growth and that at the minimum temperature of growth response no longer occurs, indicate clearly that the hydrotropism of roots is not the result of mechanical loss of turgescence on one side, but that it is on the contrary a growth phenomenon - a localized growth which is a response to a stimulus.

2. Rhizoides of Higher Cryptogams. - While it is a priori probable that the rhizoids of hepatics should react like the roots of phanerogams, MoLisch desired to demonstrate the fact 
by experiment. Upon a glass dise was placed a piece of moist filter-paper so large that its edges hung vertically downwards as a flap beyond the margin of the disc. Thalli of various Marchantiacese were placed in sand at the margin of the dise in such a way that the young growing edge projected half a centimetre beyond. The disc and the object on it were exposed to. daylight, but slowly rotated in a horizontal plane in order to eliminate phototropic action. The young, positively geotropic, rhizoids which developed beyond the margin of the disc did not. grow vertically downwards, but turned towards the flap of moist filter-paper, thus proving that they are positively hydrotropic. The same is doubtless true of the rhizoids of ferns.

3. Stems. - Very few studies seem to have been made upon the hydrotropism of the stems of seedlings; the most important are those of Molisch. Several sets of experiments were carried out upon seedlings of flax, pepper-grass (Lepidium sativum), bean, Nicotiana camelina, etc. The method employed was nearly that of Wortuans (see below). Of these plants the hypocotyls of the flax alone showed any hydrotropism; it may accordingly be concluded that stems are markedly hydrotropic in but few seedlings.

4. Pollen-Tubes. - The reactions to moisture of these organs have been studied by Mrroshi ('94). He placed pollen-grains on the stigma of the same species and found that whereas in a dark, moist chamber the pollen-tubes grew in all directions, when dry air was admitted the pollen-tubes turned towards the centre of the stigma. This turning is best explained as a response to the greater moisture surrounding the mouth of the stigma. It is clearly also an advantageous result, since it tends to direct the pollen-tube to the ovary.

5. Hyphæ of Fungi. - While Sachs ('79) early suggested that the sporangium bearer of Phycomyces nitens is negatively hydrotropic, the first experimental evidence on this point was offered by WORTMANN ('81).

Spores of Phycomyces were sown on bread kept in a moist chamber whose walls were made opaque to prevent phototropism. When, after three or four days, some of the sporangium-bearers had gained a height of one or two centimetres all were bent to one side excepting one which protruded 
through a small hole in the glass disc. Parallel to this hypha and close to it was placed a piece of soaked card. After 4 to 6 hours the hypha turned from the damp card; but when the card was dry no such turning occurred.

The extraordinary sensitiveness of the sporangium bearing filaments of Phycomyces has been shown by the experiments of Errara ('93). He found that these organs turned toward rusting iron, china-clay, agate (but not rock crystal), and sulphuric acid. He explained this result on the ground that these substances absorb the moisture in their vicinity. Consequently the hydrotropic filaments turn towards this relatively dryer region. So sensitive, indeed, is this plant that it may be used to detect a very slight difference in the hygroscopic properties of chemically related substances.

Not only do the hyphæ of Phycomyces turn from moisture, but, as Molisch ('83) showed, those of Mucor stolonifer and the relatively great trunk of the toadstool Coprinus velaris respond in the same way. The spores are thereby carried away from the moist situation.

In conclusion a word may be said concerning the cause of hydrotropism. It is probable that two diverse phenomena are confused under the term. One of these is seen when a multicellular organ like the root of phanerogams is-unequally moistened on opposite sides; the moister side will lose water less quickly than the other, or it may actually imbibe some. Its cells will accordingly become more turgescent and the whole moister side more convex. This result is due to a relatively direct, almost mechanical, cause ; it simulates negative hydrotropism, but it is so different in kind from the true phenomenon that it may be called false hydrotropism.

In the second class of cases we see multicellular organs, such as roots, becoming concave towards the slightly moister region, or unicellular organs, such as rhizoids, pollen-tubes and hyphæ - organs which cannot be supposed to become unequally turgescent on the two sides - exhibiting a + or - turning. These cases cannot be explained on direct mechanical grounds; they are responses to stimuli, and, as such, examples of true hydrotropism.

These two kinds of hydrotropism may occur in the same organ under different conditions and thus cause turnings in 
opposite directions. Thus Wortmann ('81, p. 374) finds that a mycelium growing downwards towards water turns horizontally before touching it and branches profusely. Similarly a root growing towards water will not penetrate into it, but will turn to one side. The greatly increased moisture causes the reversal of the tropism, but this is probably due to the fact that a false hydrotropism replaces the true response; however, as true hydrotaxis may take place in both directions, so there may be a true negative as well as positive hydrotropism.

I now summarize our conclusions concerning the effect of water upon growth. Water plays a part in growth second in importance to no other agent, so that in its absence growth cannot oceur. As the quantity is increased, growth is increased until an optimum is reached. The amount imbibed does not, however, depend directly upon the amount available, but rather upon the needs or the habits of the species. Growth of elongated organs may take place from or towards moisture, and the turning may be a true response to the stimulus of higher or lower aqueous tension, - a response which may show itself in a bending at some distance behind the irritable tip. This response is, moreover, often of an advantageous kind, directing the rootlets towards water and the pollen-tube towards the moist stigma or keeping the sporangium in the dry atmosphere necessary for the production of dry spores. In a word, imbibition of water and growth with reference to the source of moisture are regulated to the advantage of the species.

\section{LITERATURE}

Darwin, C. '80. The Power of Movement in Plants. London, 1880.

Darwin, F. '93. On the Growth of the Fruit of Cucurbita. Ann. of Bot. VII, 459-487. Pls. XXII, XXIII. Dec. 1893.

Detlefsen, E. 'S2. Ueber die von Ch. Darwin behauptete Gehirnfunction der Wurzelspitze. Arb. a. d. bot. Inst. Würzburg. II, 627-647.

Duchartre, P. '56. Influence de l'humidité sur la direction des racines. Bull. Soc. bot. France. III, 583-691.

Errara, L. '93. On the Cause of Physiological Action at a Distance. Rept. Brit. Ass. Adv. Sci. for 1892, 746, 747. 
GaIn, E. '92. Influence de l'humidité sur la végétation. Compt. Rend. CXV, 890-892. 21 Nov. 1892.

'95. Recherches sur la rôle physiologique de l'eau dans la végétation. Ann. Sci. Nat., Bot. (7), XX, 63-215. Pls. I-IV.

Hoffmans, '65. Beiträge zum Keimungsprocess. Landwirthsch. VersuchsStat. VII, 47-54.

Johnson, H. '29. The Unsatisfactory Nature of the Theories proposed to account for the Descent of the Radicles in the Germination of Seeds, shewn by Experiments. Edinb. New Philos. Mag. VI, 312-317.

JunelLe, H. 'S9. Recherches physiologiques sur le développement des plantes annuelles. Revue Générale de Bot. I, 101 et seq.

Knight, F. A. '11. On the Causes which influence the Direction of the Growth of Roots. Phil. Trans. Roy. Soc. London. Pt. I, 209-219.

LESAGE, P. '95. Recherches expérimentales sur la germination des spores die Penicillium glancum. Ann. Sci. Nat., Bot. (8), I, 309-322. Nov. 1895.

Mryoshi, M. '94. Ueber Reizbewegungen der Pollenschläuche. Flora. LXXVIII, 76-93.

Molisch, H. '84. Untersuchungen üher den Hydrotropismus. Sb. Wien. Akad. LXXXVIII ${ }^{1}$, 897-942. Taf. I.

Rernke, J. '76. Untersuchungen ïber Wachsthum. Bot. Ztg. XXXIV, 65-69, 91-95, 106-111, 113-134, 136-160, 169-171. Pls. II, III. Feb., Mar. 1576.

SACHS, J. 72. Ablenkung der Wurzel von ihrer normalen Wachsthumsrichtung durch feuchte Kö̈rper. Arb. bot. Inst. Würzburg. I, 209-222.

79. Ueber Ausschliessung der geotropischen und heliotropischen Krïummungen während des Wachsens. Arb. bot. Inst. zu Würzburg. II, 209-225.

Tsciraplowitz, F. C. 'S6. Untersuchungen über die Wirkung der klimatischen Factoren auf das Wachsthum der Culturpflanzen. Forsch. Agr. IX, 117-145. [Abstr. in Bot. Jahresber.] XIV, 57, 58.

Wiesner, J. '81. Das Bewegungsvermögen der Pflanzen. 212 pp. Wien, 1881.

Wortuanx, J. 's1. Ein Beitrag zur Biologie der Mucorineen. Bot. Ztg. XXXIX, 368-374, 383-387. June, 1881. 


\section{CHAPTER XIII}

\section{EFFECT OF TIE DENSITY OF THE MEDIUM UPON GROIVTH}

In this chapter we cannot, as hitherto, consider the effect of density upon both the rate or quantity and the direction of growth, for no studies seem to have been made upon the latter subject.

\section{$\S 1$. Effect of Density upon the Rate of Growth}

We have seen in Chapter III (p. 77) that the increase or decrease in the concentration of a solution produces, by osmosis, changes in the structure of protoplasm, in its locomotion, and in its excretory activity. It remains to be seen to what extent change in density can affect the metabolic activities concerned in growth.

The relation between the rate of growth of plants and concentration has been the subject of much study, e.g. by WIELER ('83), DeVries ('77), Jarius ('86), Jentys ('88), EschenHAGEN ('89), and StANGe ('92). It is agreed that, in general, as the solution containing the plant becomes more concentrated the seedling or the fungus (JENTYs, p. 455) grows more slowly.

The question now arises whether there is any maximum concentration at which growth is completely inhibited. Data on this subject are given by EschenHAGeN, who finds that various fungi will not grow at a concentration above the following limits :-

\begin{tabular}{|c|c|c|c|c|}
\hline & $\begin{array}{l}\text { STARCH. } \\
\mathrm{C}_{6} \mathrm{H}_{12} \mathrm{O}_{6} .\end{array}$ & $\begin{array}{l}\text { GLicerine. } \\
\mathrm{C}_{3} \mathrm{H}_{8} \mathrm{O}_{3} .\end{array}$ & $\begin{array}{l}\text { Sodium Nitrate. } \\
\mathrm{NaNO}_{3}\end{array}$ & $\begin{array}{c}\text { Common Salt } \\
\text { NaCl. }\end{array}$ \\
\hline Aspergillus . . . & $53 \%$ & $43 \%$ & $21 \%$ & $17 \%$ \\
\hline Penicillium . . . & 55 & $43^{\circ}$ & 21 & $18^{\circ}$ \\
\hline Botrytis. . . . & 51 & 37 & 16 & 12 \\
\hline
\end{tabular}


Also Racibonski ('96) found that Basidiobolus cultivated in a nutritive solution containing $10 \%$ peptone, $1 \%$ glucose, and the necessary salts, ceased to grow when the concentration of the salts reached the following percents :-

sodium chloride, $\mathrm{NaCl}, 6 \%$.

glycerine, $\mathrm{C}_{3} \mathrm{H}_{8} \mathrm{O}_{3}, 20 \%$.

potassium chloride, $\mathrm{KNO}_{3}, 11 \%$. glucose, $\mathrm{C}_{6} \mathrm{H}_{12} \mathrm{O}_{6}, 25 \%$.

The foregoing maximum concentrations vary with the molecular weights of the dissolved substances, indicating that their effect is purely an osmotic one.

Germination is likewise affected by concentration, as a valuable series of experiments by VANDEveLDE ('97) clearly shows.

Seeds of the pea, Pisum sativum, were soaked for 24 hours in solutions of common salt varying from $1 \%$ to $35 \%$, then removed, planted, and the percentage of seeds which germinated $(\mathrm{G} \%)$ and the mean interval elapsing before germination (I) determined. (I) was, more precisely, the time elapsing (in days) before one half of the seeds had germinated. The results are given as follows :-

\section{TABLE XXXVIII}

Showing the Recation between the Concentration of the Solution in which Peas have been soaked and their Germination

\begin{tabular}{|c|c|c|c|c|c|c|c|c|c|c|c|}
\hline$\%$ & G\% & 1 & $\%$ & G \% & I & $\%$ & G $\%$ & I & $\%$ & G $\%$ & I \\
\hline 1 & 98.00 & 2.1 & 10 & 12.46 & 5.9 & 19 & 4.00 & 5.7 & 28 & 6.83 & 5.7 \\
\hline 2 & 97.17 & 3.7 & 11 & 7.00 & 6.6 & 20 & 5.67 & 5.7 & 29 & 3.83 & 6.7 \\
\hline 3 & 85.17 & 4.0 & 12 & 10.00 & 6.3 & 21 & 3.33 & 7.0 & 30 & 10.33 & 6.5 \\
\hline 4 & 34.50 & 4.6 & 13 & 8.50 & 6.8 & 22 & 1.50 & 5.6 & 31 & 8.83 & 6.8 \\
\hline 5 & 32.66 & 4.8 & 14 & 7.19 & 6.3 & 23 & 1.83 & 6.2 & 32 & 10.67 & 7.2 \\
\hline 6 & 16.83 & 5.0 & 15 & 4.50 & 6.7 & 24 & 4.00 & 5.8 & 33 & 23.00 & 6.2 \\
\hline 7 & 15.39 & 5.2 & 16 & 6.83 & 7.1 & 25 & 0.83 & 5.8 & 34 & 31.33 & 6.5 \\
\hline 8 & 14.83 & 5.3 & 17 & 4.76 & 6.6 & 26 & 4.50 & 6.3 & 35 & 56.83 & 7.0 \\
\hline 9 & 12.66 & 5.4 & 18 & 3.33 & 6.2 & 27 & 8.17 & 6.8 & & & \\
\hline
\end{tabular}

This table yields some remarkable results. As the concentration increases from $1 \%$ to $15 \%$, the percentage of germinations diminishes from 98 to 4.5 , and the mean germination interval increases from 2.1 days to nearly 7 , near which point it remains at all higher concentrations. From $15 \%$ to $29 \%$ the percentage of germinations fluctuates so irregularly between 6.8 and 0.83 that within these limits it may be considered con- 
stant. As the concentration increases from $29 \%$, instead of the grains all being killed or failing to germinate, we have the interesting result that the percentage of germinating individuals rises rapidly from 4 to 56 . VANDEVELDE hazards the following explanation of this result: "Dilute solutions are easily absorbed; the more concentrated the solution, the smaller the power of diffusion; in a saturated solution the seeds do not swell and the action of the surrounding solution is less injurious." But we need to know more of the conditions under which this result occurs before we can accept any interpretation.

With animals we find growth similarly affected as with plants. LoEb ('92) first showed this in his experiments upon the regenerative growth of decapitated tubularian hydroids. The regenerating hydroids were kept in water more and less dense than, and equally dense with, sea water. At the end of eight days the length of the regenerated piece was measured in seven to nine individuals at each concentration. The results may be given in the form of a curve (Fig. 98) by laying off as abscissie the percents of sodium chloride in the water and as ordinates the corresponding average growth in millimetres :-

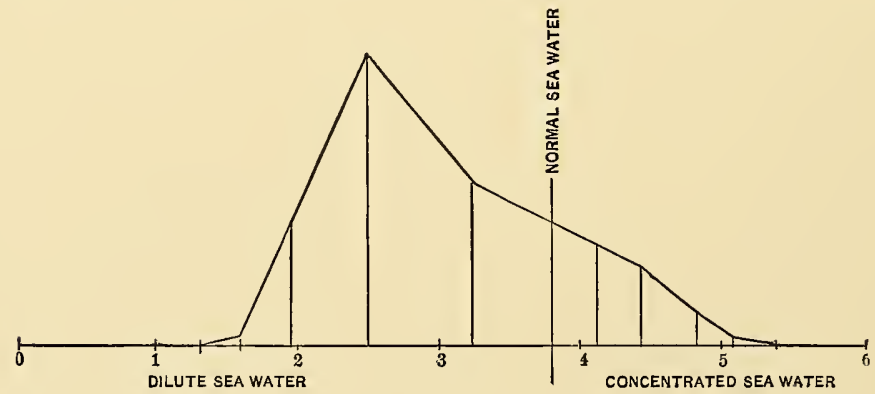

Fig. 98. - Curve showing the relation between the density of the medium and the proportional rate of growth of regenerating Tubularia. The maximum ordinate indicates $10.5 \mathrm{~mm}$. growth in 8 days. The numbers at the base of the curve are per cents of density in excess of distilled water; thus " 3 " signifies a specific gravity of 1.03. (From LoEB, '92.)

This curve shows that the optimum concentration for growth is not, as might have been expected, the normal concentration, but one considerably below the normal, namely $2.5 \%$ instead 
of $3.8 \%$. Anything which favors endosmosis seems, within certain limits, to favor growth.

Regenerating annelids have also been studied at my laboratory by Mr. J. L. Frazeur. A large number of worms of a species of Nais, all of approximately the same size, were cut into two parts. Of these the anterior, consisting of twelve segments, was alone preserved for experimentation, and was placed in water either pure or containing a variable amount of common salt in solution. At the end of ten days the anterior piece had regenerated at its tail end a certain number of segments varying with the strength of the solution as shown in the following:-

\section{TABLE XXXIX}

Showing the Average Number of Segments of Nais regenerated per Day in Various Solutions of Sodium Chloride

\begin{tabular}{|c|c|c|c|c|c|}
\hline Solution. & $\begin{array}{c}\text { No. of } \\
\text { INDIVIDUALS. }\end{array}$ & $\begin{array}{l}\text { A TG. NO. OF } \\
\text { SEGMENTS } \\
\text { REGENERATED } \\
\text { PER DAY. }\end{array}$ & SOLution. & $\begin{array}{c}\text { No. oF } \\
\text { INDIVIDUALS. }\end{array}$ & $\begin{array}{l}\text { ATG. No. of } \\
\text { SEGMENTS } \\
\text { REGENERATED } \\
\text { PER DAY. }\end{array}$ \\
\hline Water & 15 & 2.13 & $0.250 \%$ & 7 & 1.19 \\
\hline $0.125 \%$ & 5 & 1.72 & 0.375 & 5 & 1.18 \\
\hline 0.188 & 16 & 1.42 & 0.500 & 5 & 1.14 \\
\hline
\end{tabular}

The decrease in the number of regenerated segments was thus, with increasing concentration, at first rapid, then slow.

Fission, which is so closely bound up with growth that we may treat it as an index of growth, is also controlled by the concentration of the medium. Mr. P. E. SARgent has, at my suggestion, studied this subject in the naid Dero vaga. This species divides so rapidly that ordinarily it doubles its numbers every ten days. The worms were kept in solutions of varying concentration of various salts. They were reared in similar jars, supplied with similar food,* and kept under otherwise similar conditions. A definite number of worms having been put in each jar, the increment at the end of ten days was deter-

* 1 to 2 cc. of corn meal extract was added every day to the $200 \mathrm{cc}$. of water in which the worms were living. 
mined by counting. The results of some of these countings are given below for a number of salts :-

TABLE XL

Average Increase Per Cent of Indriduals of Dero raga reproducing, during Ten Days, in Solutions of Different Salts at Varying Concentrations. Minus Quantities indicate Diminution in Number of INDIVIDUA LS

\begin{tabular}{|c|c|c|c|c|c|c|c|c|c|c|}
\hline $\begin{array}{l}\text { Strengti of SOLU. } \\
\text { TION. }\end{array}$ & 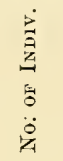 & $\begin{array}{l}\text { 官 } \\
\text { 艺 }\end{array}$ & 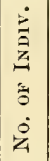 & 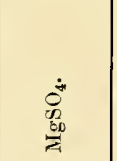 & $\begin{array}{l}\dot{5} \\
\dot{B} \\
\vdots \\
5 \\
\dot{0} \\
\dot{z}\end{array}$ & ت્ّ & 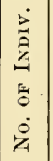 & 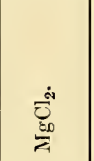 & 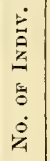 & $\dot{D}$ \\
\hline Molec. Weights, & & 58.5 & & 120 & & 111 & & 95 & & 74.6 \\
\hline Control: water & 787 & $113.0 \%$ & 75 & $134.0 \%$ & & & & & & \\
\hline $0.05 \%$ & 100 & 85.2 & 50 & 22.0 & 50 & $40 \%$ & 25 & $12 \%$ & 50 & $12 \%$ \\
\hline 0.10 & 350 & 77.0 & 75 & -10.6 & 50 & -12 & & & 50 & -64 \\
\hline 0.15 & 100 & 58.0 & 75 & -2.6 & 25 & -36 & 25 & -28 & 25 & -92 \\
\hline 0.20 & 350 & 40.8 & 75 & -35.3 & 50 & -58 & 25 & -68 & & \\
\hline 0.25 & 100 & 21.5 & 75 & -65.3 & 25 & -72 & & & & \\
\hline 0.30 & 350 & 3.2 & 75 & -84.0 & 25 & -84 & & & & \\
\hline 0.35 & 25 & -24.0 & & & 25 & -92 & & & & \\
\hline 0.40 & 375 & -18.1 & & & 25 & -100 & & & & \\
\hline 0.50 & 150 & -35.0 & & & & & & & & \\
\hline
\end{tabular}

These columns, and especially the first one, show a close relation between concentration and growth (as tested by multiplication of individuals). They show also that the diminished growth falls off rapidly at first with slight increments of concentration, then less slowly at the higher grades (Fig. 99). Finally they show that different salts have diverse osmotic effects, for sodium chloride is less retarding than any other salt at the same percentage of concentration. The effect of the remaining salts is seen to increase as the molecular weight diminishes, and therefore the osmotic effect increases (Fig. 99). The fact that magnesium sulphate dissociates at these weak concentrations only about two-thirds as much as calcium chloride does, would lead us to expect even a relatively smaller effect as compared with calcium chloride than we find (see p. 74, note); perhaps further experimentation would give facts 
agreeing closer with theory. On the whole, Table XL indicates that it is the osmotic effect which retards growth.

In tadpoles a similar retarding effect of solutions has been observed by Yung ('85), who made solutions of $0,2,4,6$, and 8 granmes of sea salt in 1000 grammes of water, and reared frog's embryos in them. Other conditions excepting concentration were believed to be alike in all experiments. In the $0.2 \%$ solution the tadpoles developed at nearly the same rate as in pure water. In the denser solutions there was a retardation in development which increased with the density of the solution, so that in the $0.8 \%$ solution the larvæ hatched out seventeen days behind the normal time.

The effect of a sudden change in the density of the solution has been especially studied by True ('95). Beans, Vicia faba, which had radicles from 17 to $35 \mathrm{~mm}$. long, were placed directly in the solutions and held there so that the cotyledons alone were free. The cultures were kept in the dark. When the transfer was made suddenly to a $1 \%$ solution of

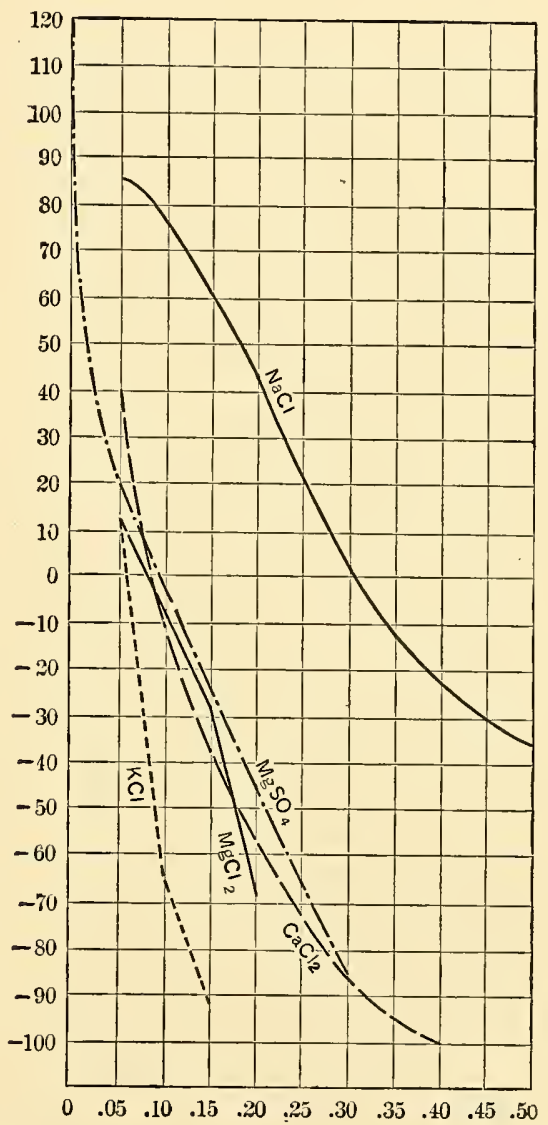

Frg. 99.-Curves of average increase per cent of individuals (ordinates) of Dero vaga reproducing, during 10 days, in solutions of different salts, whose strengths are laid off as abscissæ. The data are taken from Table XL.

potassium nitrate, it was observed that a mechanical contraction occurred, followed by a more or less prolonged period of retar- 
dation in the rate of growth. When, on the other hand, the plant was transferred from a salt solution to which it had become accustomed to pure water, a mechanical elongation quickly occurred, but this too was followed by a retardation in the rate of growth. Thus the reduction in the rate of growth is not a mechanical result of change of medium, but is a response to the stimulus of changed environment.

We have hitherto considered almost exclusively the effect of aqueous solutions. IVe must now consider how a variation in the pressure of the atmosphere affects the growth of plants. Upon this subject experiments have been made by JACCArD (93), who found that when the pressure of the air was reduced from $78 \mathrm{~cm}$. to between $10 \mathrm{~cm}$. and $40 \mathrm{~cm}$. of mercury, growth is two or three or even six times as rapid as in ordinary air. Likewise when the air is compressed to between three and six atmospheres acceleration in growth occurs, although not to the same extent as in the depressed air. If, however, the rarefaction is very great (below $10 \mathrm{~cm}$.) or the pressure excessive (over 8 atmospheres), growth is retarded. Experiments indicate that this result is not wholly due to the concentration of the oxygen in the air. We may therefore conclude that a change in pressure from the normal accelerates growth by irritating the growing plasma up to a certain limit, beyond which its injurious effects counterbalance its favorable ones.

Summing up this account of the effect of concentrated solutions upon the growth of organisms, we find that in general as the density increases beyond the normal the rate of growth diminishes until, at a certain concentration, it ceases. In the particular case of marine organisms a reduction in concentration to a certain point causes excess of growth; below that point, diminution. It is probable that the diminution in growth is proportional to the osmotic action of the medium (Chapter III).

An explanation of the foregoing phenomena may be attained by reference to the principles laid down in preceding chapters. In Chapter $\mathrm{X}$ it has been shown that growth depends very largely upon the specific imbibition of water. We do not know the cause of the difference in imbibitory properties at. different times; but if, as has been suggested, it is purely an endosmotic phenomenon resulting from the secretion of plant. 
acids or salts in the cell sap, then we can understand how a denser medium should diminish or destroy the imbibitory tendency. On the other hand, a change in concentration may act in a more indirect fashion to cause increased growth; namely, by calling forth a response to the irritation of changed conditions of pressure.

\section{LITERATURE}

Eschenhagen, F. 'S9. Ueber den Einfluss von Lösungen verschiedener Concentration auf das Wachsthum von Schimmelpilze. Stolp, 1889.

JACCARD, P. '93. Influence de la pression des gaz sur le développementodes végétanx. Comp. Rend. CXVI, 830-833. 17 April, 1893.

JARICs, M. '86. Ueber die Einwirkung an Salzlösungen auf den Keimungsprocess der Samen einiger einheinischer Culturgewächse. Landwirthsschaft. Versuchs-Stat. XXXII, 149-178. 'Taf. II.

Jextrs, S. '88. Ueber den Einfluss hoher Sauerstoffpressungen auf das Wachsthum der Pflanzen. Unters. a. d. bot. Inst. Tübingen. II, 419-464.

Loeв, J. '92. (See Chapter X, Literature.)

Raciborski, M. '96. Ueber den Einfluss äusserer Bedingungen auf die Wachsthumsweise des Basidiobolus ranarum. Flora. LXXXIII, $110-115$.

Stange, B. 92. Beziehungen zwischen Substratconcentration, Turgor und Wachsthum bei einigen phanerogamen Pflanzen. Bot. Ztg. L, 253 et seq.

True, R. H. '95. On the Influence of Sudden Changes of Turgor and of Temperature on Growth. Amn. of Bot. IX, 365-402. Sept. 1895.

Vandevelde, A. J. J. '97. Ueber den Einfluss des chemischen Reagentien und des Lichtes auf die Keimung der Samen. Bot. Centralbl. LXIX, 337-342. 11 Mlarch, 1897.

DE VRies, H. '77. Ueber die Ansdehung wachsenden Pflanzen-zellen durch ihren Turgor. Bot. Ztg. XXXV, 1-10.

Wieler, A. '83. Die Beeinflüssung des Wachsens durch verminderte Partiarpressung des Sanerstoffs. Unters. a. d. Bot. Inst. Tübingen. I, 189-232.

Yung, É. 's5. De l'influence des variations du milieu physico-chimique sur le développement des animaux. Arch. des Sci. Phys. et Nat. XIV, 502-522. 15 Dec. 1885. 


\section{CHAPTER XIV}

EFFECT OF MOLAR AGENTS UPON GROIVTH

IT is proposed in this chapter to consider, first, the effect of contact, rough movements, deformations, and associated molar agents upon the rate of growth, and, secondly, the effect of such agents upon the direction of growth.

\section{\$1. Effect of Molar Agents upon the Rate of Growth}

We have already (Chapter IV) seen that profound changes in metabolism and the motion of protoplasm are induced by various sorts of contact. We shall here consider how those changes result in modifications of growth.

1. Contact. - In the case of organs which normally grow upon a solid substratum the growth may take place more rapidly after coming in contact than before. Thus Loeb ('91, p. 29) says of the stolons of the hydroid Aglaophenia pluma, that when they reach a solid surface they begin to grow more rapidly than stolons which develop free in the water. Evidently the stimulus of contact excites to extraordinary growth.

2. Rough Movements. - Experiments with this agent have been almost confined to bacteria, and have been made by shaking. The first experimenter in this direction was Horvath ('78), whose method of work is worth giving in some detail.

Glass tubes about $20 \mathrm{~cm}$. long and $2 \mathrm{~cm}$. wide were half filled by a nutritive fluid, inoculated with an infusion full of various bacteria, and sealed. The tubes were then fixed on a board which was made to swing horizontally to and fro by means of a motor through an arc of about $25 \mathrm{~cm}$. length at the rate of 100 to 110 times per minute. At the end of each excursion the board received, by means of a special device, an extra blow. The resulting agitation was like that made in shaking a test-tube. 
The results of Horvath's experiments were these. Tubes which were shaken for 24 hours were clear at the end of that period, while similar tubes kept at rest had become mudd $\dot{y}$ with bacteria in the same time. If, now, the shaken tubes were kept at rest during a day in a warm oven, they, too, produced a rich growth of bacteria. When, however, the tubes had been shaken for 48 hours they not only were found clear, but they did not become cloudy upon subsequent warming (I, p. 99). The shaking during the briefer period had thus merely interfered with the normal growth processes, but the more prolonged shaking had resulted in the death of the bacteria.

Subsequent attempts by other workers to reproduce these results, by the use, however, of other methods, partially or completely failed. RErske ('80), indeed, found that in water agitated for 24 hours bacteria had ceased to grow, but had not been killed; in so far a confirmation of Horvath. Other investigators, however (BuCHNER, '80; TUMAS, '81; LEONE, '85; Schumd, '91; Russell, '92; and others), have either obtained no effect upon the growth of bacteria, or have found it increased by motion. The results seemed hopelessly discordant.

The more recent work of Mectzer (94) has, however, brought these conflicting observations under one general law, and has thus offered an interpretation of the varied results. He pointed out first that the diverse results of previous investigators were due to the use of different species of bacteria and of different kinds and degrees of shaking; in a word, to dissimilar methods. MeLTzer employed pure cultures of bacteria of ascertained species, and counted the colonies by the wellknown bacteriological methods. Shaking was either violent, being done in a machine somewhat like Honvatu's; or slight, being done by hand. The media used were neutral salt solutions, KocH's bouillon, or pure water. The results showed that a slight shaking is advantageous to the metabolism of Bacterium ruber in water. Thus, while a culture containing 950 colonies, left quiet, was reduced after 8 days to 259 colonies; shaken, it had at the end of the same period 1366 colonies; and shaken with glass drops rolling loose in the tube, 
it had attained 16,200 colonies. When, however, the shaking was longer continued the number of colonies began to fall off, so that after 21 days the medium shaken with glass drops exhibited only 5 colonies. These facts enable us to distinguish a minimum degree of movement which will permit of growth (shaking for 6 days without glass drops); an optimum (shaking for 8 days with glass drops); and a maximum (shaking for 21 days with glass drops). The optimum is very diverse in different species. Thus in Bacterium megaterium it is so low that shaking for a little over 1.5 days results fatally. It is probable that the growth of every race of bacteria is attuned to a particular optimum of movement.*

3. Deformation. - Under this head we may consider the effects of pulling and bending upon the growth of an elongated body. Data upon this subject have been obtained only from plants.

The effect of pulling upon the growth in length of a plant stem has been studied by Baranetziky ('79), ScholTz ('87), and Hegler ('93). The results obtained are concordant and important. It appears that when a weight is attached, by means of a cord running over a pulley, to the epicotyl of various seedlings - such as Helianthus, Tropæolum, Cannabis, Linum, etc., - the growth in length of the stem is, under appropriate conditions, not accelerated but retarded. When, for example, a pull of 13 grammes is exerted upon the epicotyl

* Concerning the cause of the increase of growth accompanying a slight molar disturbance and the diminished growth and death accompanying a violent one, Meltzer has something to say. He finds in those cultures in which no growth of bacteria occurs, no fragment of cells but on the contrary nothing except a fine "dust" - the bacteria have experienced a molecular disintegration. In order to explain this disintegration, MELTZER accepts NäGELI's conception of the structure of protoplasm, - micellæ enveloped by water, - and supposes that a molar disturbance modifies the normal movements of these micellæ. A very violent movement causes the micellæ to separate completely; a much less turbulent movement causes an increase in the vibrations of the micellæ by which they are brought into more intimate contact with food material including oxygen, and more easily get rid of the metabolic products. Without accepting NÄGELI's micellar hypothesis, we may account for the beneficial effects of slight movement upon the ground of an increased supply of oxygen afforded by it; and we may regard the fatal effect as the result of disturbed metabolism or of protoplasmic disintegration. 
of a Cannabis seedling there is a momentary elongation followed for six hours by no growth whatever; then periods of growth alternating with periods of retardation occur until, after perhaps 24 hours, the hourly growth is nearly equal to that of the unweighted plant. The least weight which will cause a retardation is different for different plants. In the case of Cannabis and Linum it is below 1.3 grammes, a result which indicates that the weight of the index used in self-recording auxanometers is sufficient to retard the growth of the plant and thus to give an abnormal growth curve.

The diminution of growth is not the same at all periods of the plant's development. Thus the retarding effect is greatest at the commencement of the grand period of growth, but begins quickly to diminish until at the maximum of growth there is no retarding effect. Then, as the rate of growth decreases, the retardation becomes more evident. The effect of the pull is best seen in comparing the curves of daily fluctuation of growth of the weighted and unweighted plants. 'The early morning is the period of rapid growth, and at this time the growth of the stretched plant is quite equal to or exceeds that of the un-

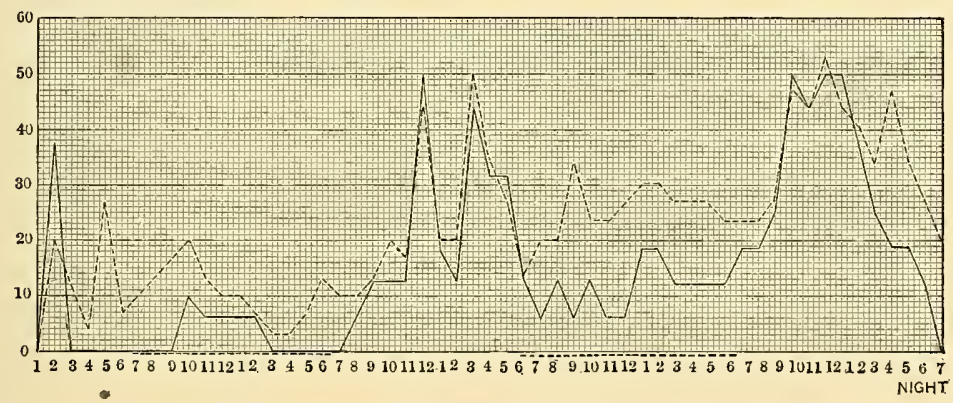

Fig. 100. - Curves of hourly growth, measured in hundredths of a millimetre, - vertical seale at the left. The full line gives the course of growth of a Cannabis seedling subjected to a pull of 13 grammes. The dotted line gives, for comparison, the course of nearly normal growth, the plant being subjected to a pull of only 3 grammes. The numbers at the bottom indicate hours of the day; the broken line at the bottom indicates night-time. (From HegLer, '93.)

weighted one. During the early night, on the contrary, when growth is feeble, the stretched stem grows slowly (Fig. 100). If an etiolated plant is used, the daily growth fluctuations are eliminated and the effect of the larger growth cycle becomes 
evident. Thus, in general, the more rapid the growth, the less is the retardation provoked by pulling.

The direction in which we must look for an explanation of these facts is indicated by the circumstance that, in the most rapid period, growth is chiefly due to imbibition of water, while in the preceding and succeeding periods it is due more to an increase in the plasma. Thus not all kinds of growth are equally affected by the irritation of pulling, but principally that growth which is due to assimilation. Further insight into this matter is gained from the circumstance that despite the fact that growth is slower in the plant under tension the turgescence in the stretching zone is greater in such a plant than in a normal one. This indicates again that it is not the imbibitory process which is interfered with but rather the assimilative one. All these facts thus lead to one conclusion, that, under tension, the plasma, especially that of the cell-wall, grows in length less rapidly than under normal circumstances. This diminution of growth can hardly be explained in a direct mechanical way; we must consider it a response to the stimulus of pulling.

A confirmation of this conclusion is found in the fact that the effect of the pulling gradually wears off. Thus when one of a pair of seedlings of Cannabis sativa is subjected to a pull of 20 grammes, there is a retardation during the first day of $61 \%$ in the stretched plant as compared with the control plant; during the second day of $51 \%$; during the third day of only $9 \%$. (Hegler, '93, p. 389.) In order that the retardation should continue, additional weight must be imposed; then an increased retardation occurs. Thus in one case Hegler subjected one of two Helianthus seedlings to a pull of 50 grammes. During the first day the retardation of the pulled plant was $20 \%$; during the second there was an excess of growth over the control of $17 \%$; then 150 grammes were added; on the third day the retardation was $18 \%$; on the fourth there was an acceleration of $2 \%$. This series of phenomena is clearly like that which we have observed in locomotion - there is an accommodation of the growing protoplasm to the stimulus.

'There can be little doubt that in the cases of diminished growth in length there is a thickening of the cell-walls and 
probably an increase in cross-section of the whole stem. There is indeed considerable experimental evidence for this conclusion. Thus Schenck ('93) found that when stems are irritated by twisting or bending, an excessive growth both of cell-walls and of the wood as a whole follows. So, too, Newcolrbe ('95) finds that roots become strengthened by attaching weights to them. In fact, if stems are deprived of their normal swaying movements, for instance by enclosing internodes in plaster casts which inhibit lateral movements and partly support the weight of the superior part of the plant, their walls remain abnormally thin.

These effects of deformation are of especial importance because they are so clearly not at all directly mechanical but adaptive; they are, indeed, rather opposed to the direct mechanical effects which would tend to stretch the cells, and thus to diminish the thickness of their walls. Here again the organism shows itself a highly irritable thing, capable of responding in an adaptive fashion.

4. Local Removal of Tissue. - When a protist, for instance a Stentor, is transsected, certain changes take place along the cut surface. First, there is a warping of the edges towards each other; secondly, rapid growth (differential growth, page 287) occurs. Similarly, if a Hydra be eut lengthwise, the free edges may fold towards each other so as to form a smaller cylinder, and the seam, by growth, will be healed over. So, too, in the higher animals, the removal of a bit of tissue results usually in the closure of the wound and growth to fill the gap. We may call these two processes warping and regenerative growth.

The causes of these two processes are probably different. The warping seems to result from the presence of tensions and pressures in the tissues whose equilibrium is disturbed by the cut. This process is probably grossly mechanical. The regenerative growth, however, must have a less direct explanation. It is apparently a typical response to the stimulus of cutting, or of the new environment presented at the cut edge.

Here, too, may be mentioned an experiment by Loes ('92, p. 51), which throws light upon the cause of these internal tensions. Below the crown of tentacles of a Cerianthus a 
horizontal slit was made in the side of the body-wall. The tentacles over the slit contracted - there was a sort of negative

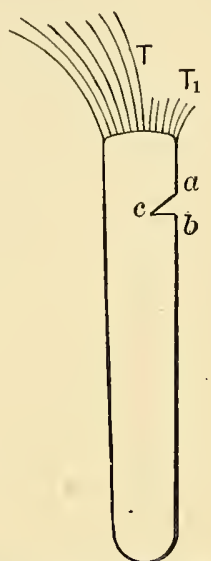

Fig. 101. - Cerianthus, from which a piece, $a, b, c$, has been cut, eausing a loss of turgesceuce and consequent shriuking of tentacles on the cut side. (From LoEB, '92.) growth. The shortening was doubtless due, as LOEB says, to the loss of water and consequently of turgescence in this part of the body-wall (Fig. 101). I have cut the bodywall of a hyclroid immediately below an incipient bud, whereupon the bud at once flattened out. These experiments show how important water pressure is for the maintenance of the size of the body and for growth, and in so far explain the mechanical effect of a cut or other similar wound.

\section{§ 2. Effect of Contact upon the Direc-} TION OF Growth - Thignotropism

Having seen that molar agents can affect the rate of growth, we are in a position to understand how a molar agent, acting upon one sicle only of an elongated organ or plate of tissue, may induce a less or greater growth upon that side, and, consequently, a bending towards or from it. This turning phenomenon may now be considered. Before taking up the permanent growth turnings, however, we may consider a case of transitory growth, which throws valuable light upon the true nature of thigmotropism, and serves to connect it with thigmotaxis. This is the ease of the pseudopodia of Orbitolites, which, according to VERwOrN ('95, p. 429), float at first free in the water after being protruded through holes in the shell; but as soon as they grow longer and heavier they sink in the water, until their distal ends touch the substratum. To this they become attached by a delicate secretion, and grow out along it by the streaming of the protoplasm. The persistent clinging to the substratum is a thigmotropic reaction, and one which belongs clearly to the category of response.

1. Twining Stems. - The characteristic form of twining plants, like the bean, has long excited the interest of natural- 
ists. A study of the cause of this form was made by PALMI ('27), by Mohl ('27), and by Dutrochet ('43,'44); and from this early period to the present there have existed on this matter great differences of opinion. On the one hand, there has been maintained a view that had great inherent probability, the view, namely, that the twining of plants is a response to the contact-stimulus of the object about which they are coiled. Against the general validity of this view certain experiments of DArwin ('82, p. 16) seem conclusive. For he found that even the hard rubbing of the stalk caused no modification of the normal spiral growth. Accordingly, the conclusion seems generally accepted to-day that the peculiar form of growth of most twining plants is the combined result of geotropism, by which the stem grows upwards, and a special form of nutation, by which it impinges against the supporting stick and bends round it. The twining is thus mechanical, - depending upon the structure of the stem, - rather than responsive.

An exception among twining plants is found in the dodder, Cuscuta. This plant is a parasite, belonging to the Convolvulus family, and lives upon the flax and other plants. It is leafless, and twines closely about its host, into which it sends the feeding organs - the haustoria. According to the careful studies of PEIRce ('94), the stem, when not in contact with any solid body, makes long, steep turns about the axis of the spiral, as is the case with other twiners. If now the free stem, during a period of slow growth, be brought into contact with a wooden or glass rod or a thread at about $3 \mathrm{~cm}$. from the tip, the stem bends sharply, and in the course of 15 hours makes two or three close turns around the vertical support. If the contact be made at a distance of only about $1 \mathrm{~cm}$. below the tip, there will be little or no change in the character of the twining. If the point of contact be too far below the tip, -6 to $7 \mathrm{~cm} .,-$ there will also be no effect. The result is thus clearly dependent upon a stimulus applied at a definite sensitive point; it is a typical response.

2. Tendrils. - Very similar to the phenomena of close twining in Cuscuta is that of coiling in the tendrils of phanerogams - those most marvellously sensitive of all plant structures. Darwin ('82) and Pfefrer ('85), particularly, have 
studied by experimental methods the movements of these organs. The conditions which induce the twining of tendrils are peculiar. It appears that tendrils are not irritated by mechanical shaking, such as is produced by a powerful current of air issuing from a narrow tube; nor by a drop or strong current of water, provided it contains no hard particles; nor even by a stream of mercury, or the surface of pure mercury or oil. All solid bodies, however, with the exception of moist gelatine, when rubbed against the stem stimulate it so as to produce a bending at the irritated point.

The behavior of moist gelatine is instructive. PFefrer first observed that it was exceptional, and Perrce has found the same exception to hold for Cuscuta. PFefFer's experiments showed that, no matter how great the pressure or strokes made by drops of 5 to $14 \%$ gelatine, or by glass rods covered by a layer of moist gelatine, no response occurred; and Peirce ('94, p. 66) found that when the Cuscuta stem came in contact with a rod covered with wet gelatine it made only the long, steep turns characteristic of the free-growing stem. Later, when it reached the part of the rod not covered with gelatine, it formed at once a close, tight coil. That it is not the chemical composition of gelatine which prevents the twining is shown by the fact that dry gelatine, even to $25 \%$, irritates; also, if some sand is mingled with the moist gelatine, tropism occurs. The fact that wet gelatine does not irritate is explained by PFefrer upon the ground that the stimulus is not given by mere contact, for a blow does not produce it. A certain degree of adhesion between the tendrils and the irritating substance is necessary. The moist surface of the gelatine prevents such adhesion taking place. The effective irritation is a sort of tickling.

The degree of this tickling may, however, be extremely slight. Thus Pfeffer ('85, p. 506) placed a rider of cotton thread, weighing 0.00025 milligramme, on a tendril, and found that no effect was produced so long as it was quiet; whereas, when the rider was put in motion by a current of air, a considerable bending occurred. Under similar conditions, a thread weighing 0.00012 milligramme produced no reaction. MacDougal ('96, p. 376) finds that a spider's web, $43 \mathrm{~cm}$. 
long, suspended above a tendril of Echinocystis, caused such a reaction that the tendril coiled around and fastened to it.

Concerning the irritable region, it appears that in most tendrils there is an especially sensitive side and an especially sensitive zone. The presence of a more irritable side is not a constant character of all tendrils, however. Thus, Cobæa scandens, Cissus discolor, and others, are irritable on all sides. When a differentiation in this respect occurs, however, a bending takes place towards the more irritable side. The sensitive zone lies either at the tip or immediately below.**

The period of development at which the tendril is most irritable must also be considered. Thus, DARWrN ('82, p. 17t) says: "Tendrils which are only three-fourths grown, and, perhaps, even at an earlier age, but not whilst extremely young, have the power of revolving and grasping any object which they may touch. These two capacities . . both fail when the tendril is full grown." Pfeffer ('85, p. 485) and MüLLER ('86, p. 104) likewise find tendrils irritable only in the latter part of their growth-period. $\dagger$

There are four periods in the response to a momentary stimulus: (1) a latent period elapsing before the curvature begins to take place; (2) a period of bending; (3) a period of quiescence in the bent condition; and, finally, (4) a period of

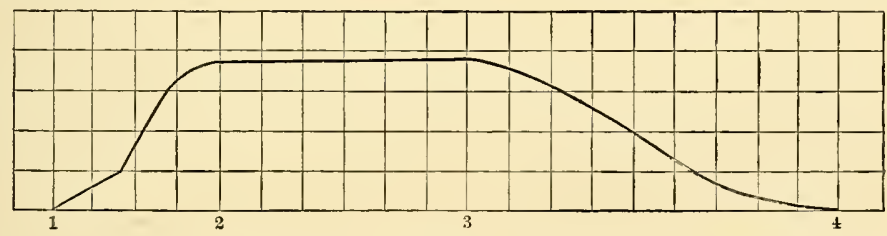

FIG. 102. - Curve of contraction of a tendril. The distance of the curve from the base represents the amount of displacement of the tip; one unit on the base-line represents five minutes of time; 1 to 2 , latent period and period of contraction; 2 to 3 , period of maintenance; 3 to 4 , period of relaxation. (From MacDougal, '95.)

* In Cuscuta, according to Peirce (94, p. 64), the tip is non-irritable; the most sensitive zone is $3 \mathrm{~cm}$. below the tip.

$\dagger$ In Cuscuta, Peirce ('94, pp. 68,64) found that neither the stalk of seedlings nor of older plants, during the period of rapid growth which follows the formation of haustoria, are sensitive. Irritability shows itself only when growth becomes less rapid, as it does some time after forming haustoria. 
straightening again. These periods are represented graphically in Fig. 102. The latent period is of variable length in different species. Perhaps the shortest period is that of Cyclanthera, which Mülles ('S6, p. 103) found to vary in the most sensitive condition of the plant from 5 to 9 seconds. DArWIN ('82, p. 172) found a latent period in Passiflora tendrils of 25 to 30 seconds, while in other cases (Dicentra smilax, Ampelopsis) this period may be 30 to 90 minutes or more in length. The entire time required for the plant to straighten completely again is, according to MüLler ('86, p. 104), for Cyclanthera about 20 minutes. These times depend, however, to a large extent upon various external agents. Thus a quick response is favored by a temperature between $17^{\circ}$ and $33^{\circ} \mathrm{C}$, sunlight rather than shade, considerable humidity, and small size of tendril. Thus this growth response resembles, in its dependence upon various conditions, other responses, e.g. those of muscle, to stimuli.

3. Roots. - Thigmotropism in roots was apparently first investigated by SAcHs ('73, pp. 437-439). He fastened germinating seeds of various species in a moist chamber so that their radicles, of about 10 to $30 \mathrm{~mm}$. length, were horizontal. A pin was now placed against the root near its tip so as to exert considerable pressure. Usually within eight or ten hours a turning of the root in the growing region occurred so that it became concave towards the pin and finally made a complete loop about it, or, if the needle was vertical, descended along it in a spiral - a result of the double action of thigmotropism and geotropism. This response was, however, rather inconstant and appeared not to be very powerful.

The sense of the thigmotropic response was, in the foregoing example, positive; that is, the turning was towards the solid body. DARWin ('81, p. 131) believed that he had evidence that the response is sometimes negative. Thus he says that the radicle of a germinating bean, coming in contact with a sheet of extremely thin tinfoil $(0.003$ to $0.02 \mathrm{~mm}$. in thickness), was in one experiment deflected without making a groove upon it; also, when a piece of paper was gummed to the root near the tip, the root usually turned so that it became convex to the gummed paper. But DARwin's conclusion has not been 
sustained by later work. Thus DeTLEFsen ('82) found that bean radicles plunged right through tinfoil $0.0074 \mathrm{~mm}$. in thickness, and WIESNER (' $8 t$ ) and SPAULDING ('9t) have shown that the turning from the gummed paper is the result of the injurious action of the gum. Indeed, it is difficult to see how a root, which must force its way through the earth, should turn from a solid surface. Experience shows rather that it turns towards it and tends to grow along it or through it.

4. Cryptogams. - Among Fungi a thigmotropic response has been observed and studied in the mold Phycomyces nitens by Errard ('84) and Worturirs ('87). They find that rubbing the sporangiferous hypha lightly with a bristle or glass thread for from three to six minutes will produce a response more powerful even than that to light. As with tendrils, $7 \%$ to $14 \%$ gelatine, almond oil, and water drops provoke no bending; but, on the other hand, even the mutual rubbing of two adjacent sporangiferous hyphre may incite a response. The response will, however, appear only when the growing region of the hypha is irritated ; if the hypha is fully grown, no thigmotropism will take place. The sharpest part of the bend will occur at the region of greatest growth, not necessarily at the point of contact. However, WorTuans finds that the turning commences at the point of contact, but becomes more and more pronounced as the bend approaches the most rapidly growing part of the hypha. The response to a brief contact is only temporary. Thus when a sporangiferous hypha $2.3 \mathrm{~cm}$. long was touched for one minute with a glass thread a bending began to appear after 15 minutes and disappeared 10 minutes later. Thus Phycomyces follows closely the laws of response of tendrils.

The rhizoids of the hepatic Marchantia and its allies have been found by MoLisch (' 84 , p. 983) to behave in a similar way to the foregoing. When the hepatics are placed on damp filter-paper, over a watch-glass, in a moist chamber and in the light, one finds after 48 hours that rhizoids have penetrated through the filter-paper. Since the paper reveals, even to the microscope, no pores, and since grains of corn starch, of from 2 to 24 microns diameter, will not pass through it, we must conclude that the root hairs of 10 to 25 microns diameter, although 
consisting of only a single cell, have the power of forcibly boring their way between the fibres of the paper. This phenomenon is most easily accounted for on the ground of response to contact.

5. Animals. - The phenomenon of thigmotropism is exhibited among animals in the power of growing along an irregular substratum. Thus the stolons of hydroids, Bryozoa, and some compound ascidians, upon once gaining the surface of an appropriate substratum, cling closely to it without reference to the direction, up or down, which the substratum may take. It is not necessary that the surface should be a rough one ; the surface film of water may incite the response. More striking is the direction of growth of regenerating hydroid stems, according to the observations of LoEB ( 91, p. 18). This experimenter found that when pieces are cut from a stem of Tubularia and are so placed in a cylindrical glass vessel that the lower end lies buried in the sand while the upper end is in contact with the side of the vessel, then, regeneration of the hydranth occurring, the new growth is perpendicular to the surface of the vessel, i.e. horizontal. This direction is independent of the direction of light rays, since it occurs at all parts of the circumference of the vessel; nor is it a response to gravity, since the stems normally assume a vertical position. The phenomena are, in so far, exactly like those in plants.

The experiments made upon plants suggest a series which might be made upon animals. Do stolons exhibit nutations to aid in the finding of the solid substratum? What substances call forth the thigmotactic response? IVill a momentary irritation cause turning? The field of thigmotropism, like that of the other tropic phenomena of sessile animals, is an imperfectly worked one.

\section{The Accumulation of Contact-Stimulus and Acclimatization} to it. - These two phenomena accompanying contact-stimulation must be alluded to. Pfeffer ( 85, p. 506) pointed out that a soft blow which calls forth no response when given once, will produce bending when given repeatedly for several minutes. The basis for an explanation of this phenomenon is given by an observation of DE VRIEs ('73, p. 307), who withdrew the support from a tendril which had already turned 
through $45^{\circ}$ as a result of contact irritation. The tendril continued to bend at the previously iruitated point even after the irritant had been removed. Thus a stimulated condition persists after the removal of its inciting cause, and this gives a chance for the building up of a powerfully stimulated condition by the accumulation of slight stimuli.

The persistence of the stimulated condition is revealed by another set of changes. Pfeffer found that the tendrils of Sicyos when repeatedly rubbed at short and regular intervals first coil and then gradually straighten out. DARwis ('82, p. 155), who had previously shown this same thing, found also that after a tendril of Passiflora gracilis had been stimulated 21 times in 54 hours it finally hardly responded at all. Similar results have been obtained with Drosera hairs (PFEFfer, '85, p. 514). Thus the constantly repeated stimulation produces such a modification of the protoplasm that it eventually fails to respond. On the one hand, this phenomenon is the same as that of fatigue; on the other, it resembles closely the condition seen in stimulated Protista referred to in.Chapter IV, $\S 3$, and there designated as acclimatization.

7. Explanation of Thigmotropism. - Concerning the cause of the bending of plants as a result of contact, I know of no better explanation than that offered by SACHS ('87, pp. 697-699). $\mathrm{He}$ ascribes the bending to a difference in the rate of growth on the two sides of the bending cylindrical organ. This is indicated by the fact that it is chiefly in the region of "stretching" that the response occurs; i.e. shortly behind the apex. At the very tip, growth by assimilation is chiefly occurring; below the region of stretching, growth is occurring only slowly. The measurements of DE VRIEs (73) have, however, shown directly that the convex side of the tendril grows faster than the straight tendril and the concave side less rapidly. The convex side thus pushes still farther over the concave, producing the coiling. As the region of stretching is one of imbibition of water, we conclude that more water is taken in on the convex side than on the concave, where even a loss of water may occur; or perhaps there is a movement of water from the irritated towards the opposite side. The irritant then produces a chemical change on one side of the organism such as to cause 
a movement towards that side or from that side according as the organ is positively or negatively thigmotropic.

\section{§ 3. EFFect of Wounding upon the Direction of} Growth - Traumatropism *

Under this head may be considered the effect of a special class of molar agents, namely, those which produce a wound, upon the direction of growth of roots. We may consider first false and then true traumatropism.

1. False Traumatropism. - When the growing tissue of the radicle of a seedling is destroyed on one side by caustic or heat,

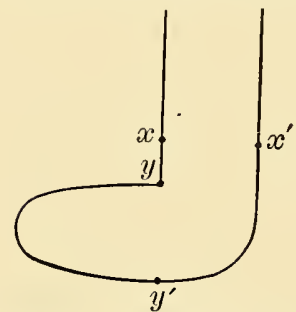

Fig. 103. - Diagram of a root tip, illustrating false traumatropism : $x y$, region of wounding. The line $y-y^{\prime}$ ran originally parallel to the line $x-x^{\prime}$, but by growth has been brought to make an angle of $90^{\circ}$ with it. the radicle turns towards that side (CrESIELsKi, '72; DARIVIN, '81; Spaulding, '94). This result is satisfactorily explained on the ground that the killing of the growing tissue on one side causes a retardation or cessation of growth on that side; so that, while the points $x, y$ (Fig. 103), remain nearly stationary, the points $x^{1}, y^{1}$, opposite to them, grow widely apart. It will be seen at once that this bending belongs to a wholly different category from the thigmotropic curvatures described in the last section. It is, as DARIVIN called it, a mechanical bending ; it is a false traumatropism. $\dagger$

2. True Traumatrocism. - Of widely different cause from the foregoing is the turning due to slight wounding which has been investigated by Chesielski ('72), Darwin ('81), Detleffen ('82), Wiesner ('84), and Spaulding ('94). DarWIN irritated the radicle of a bean by touching it near the apex with dry caustic (nitrate of silver). The point of wound-

* From Greek, $\tau \rho a \hat{v} \mu \alpha$, a wound.

$\dagger$ A phenomenon allied to this is seen when at an early stage one half of a frog embryo is killed and, consequently, remains of small size; the larger, growing, side soon comes to bend around the smaller, dead, side. A fuller account of these experiments, made by Rovx and others, upon the frog's egg, must be postponed to the next Part of this work, since it is complicated by the phenomenon of regeneration. 
ing appeared as a small, dark spot on one side of the radicle. The seedlings were then suspended in a moist chamber, over water, and at a temperature of $14.4^{\circ} \mathrm{C}$. After 24 hours almost all of the radicles showed a marked curvature from the wounded side. Other means can be used to produce this result : a thin slice cut off obliquely from the tip of the radicle, a drop of shellac, of copper sulphate, of potassium hydrate, or steam at about $95^{\circ} \mathrm{C}$. (SPAULDING) - in general, any agent which irritates strongly without killing.

Concerning the place on the root where the injury must be made in order that a response should appear, SPAULDING finds that if the branding is made further from the apex than $1.5 \mathrm{~mm}$. no traumatic curvature will occur; or if an oblique cut at the apex should not involve the growing root tip, as at $a b$, Fig. 104, it is without effect. So

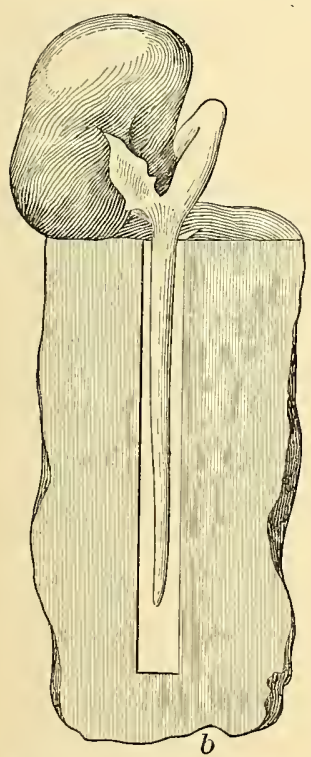

Fig. 105. - Median longitudinal section through a gypsum cast, $b$, surrounding and repressing a root of Vicia faba. Natural size: (From Pfeffer, '93.) it seems that the proliferating root tip is the sensitive part.

The point of maximum curvature is, however, not at the root tip, but lies in the region of most rapid growth. The length of time

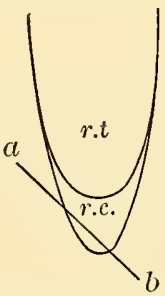

FIG. 104. - Diagram showing the relations of the root tip, 'r.t, and the root cap, r.c.; $a, b$, line of a cut which involves only the root cap. elapsing between injury and response varies with the species and with the temperature. Thus, at a temperature of $18^{\circ} \mathrm{C}$. the curvature begins in from 45 to 55 minutes, and reaches a maximum within 24 hours (WIESNER).

The long, latent period and the slowness of complete response give an insight into the reason for this separation of the perceiving and responding zones. During the latent period the irritated tissue is becoming stretching tissue through the imbibition of water, while the root tip is becoming generated in advance, leaving 
the irritated protoplasm behind. This can be demonstrated if (following PFEFFer, 93) the freshly irritated radicle is confined in a plaster cast (Fig. 105). The growth of the tip is slackened so that it does not leave the irritated tissue far behind; at the same time, the zone of stretching encroaches upon the root tip, so that, if the radicle is released after several clays, the curvature, although taking place, occurs abnormally near the tip. If the response were transmitted a fixed distance backward from the tip, we should expect that in the confined plant either the turning would take place at the normal position or would altogether fail to occur. Since neither of these effects follows, the conclusion is strengthened that the identical plasm which is irritated responds, producing the trammatic curvature.

Temperature, controlling as it does the rate of growth, controls the length of the latent period. According to the observations of WIESNER, this is at-

\begin{tabular}{c|c|c}
\hline Temperature. & IN Damp Chamber. & IN W ater. \\
\cline { 2 - 3 } & $438 \mathrm{~min}$. & $393 \mathrm{~min}$. \\
$17.0^{\circ} \mathrm{C}$. & 87 & 52 \\
$25.0^{\circ} \mathrm{C}$. & 37 & 28 \\
$33.0^{\circ} \mathrm{C}$. & 58 & 70 \\
\hline
\end{tabular}

Thus, $25^{\circ} \mathrm{C}$. seems to be about the optimum temperature for the traumatropic response; and this is a temperature $10^{\circ}$ to $12^{\circ}$ below the optimum for protoplasmic movements (Chap. VIII, § 2).

The true explanation of traumatropism renains, after prolonged discussion, uncertain. DARWIN regarded it as a response to stimulation, but DeTLEFsen and WIEsNer sought to show that it is the immediate mechanical result of the injury. Thus, Dethefsen assumed tensions in the root cap, which caused the root when cut on one side to shorten on the other; but this conclusion was disproved by SPAULDING, who found that the usual results do not follow when the root cap is injured without injuring the root tip. WEIsNer's explanation was based on the observation that decapitated roots grow more 
rapidly in water than normal ones. In like manner, if the root is, as it were, half decapitated, by cutting the tissue on one side, an abnormally rapid growth will take place on that side, proximal to the injury. The reason for this more rapid growth, continues WIESNER, is that the nutritive fluids intended for the tip are prevented by the injury from attaining the tip, and, consequently, go to build up the cell-walls above the wound. While the possibility of this explanation cannot be denied, the facts are not opposed to another interpretation, such as is offered by SPAUlding, and which is more in accord with the explanations of other tropic phenomena. This explanation is that the wounding produces a chemical change in the protoplasm of one side of the root, such that growth occurs more rapidly upon that side, either as a result of increased upbuilding of cell-walls or of increased imbibition of water, or of both.

\section{§ 4. Effect of Flowing Water upon the Direction of Growth - Rheotropisi}

When the radicle of a bean is suspended by the cotyledons above a stream of flowing water, so that it lies in the axis of the current and points down stream, the free end, as it grows, gradually turns, and becomes directed up stream. It turns against the current.

This remarkable phenomenon, named rheotropism by its discoverer, Jönssox ('83, p. 518), has been carefully studied by him by the following method: The stream, whose rate could be controlled at will, flowed in a trough. Over the current, seedlings of maize and other grains, with well-developed radicles, were suspended so that the radicles lay in the axis of the current, and were directed either up stream or down as desired. When the rootlets were directed down stream, a turning began, after a latent period of several hours, and reached its final position in the current in about twenty hours. If the rootlet was originally directed up stream, it simply grew straight ahead until mechanically bent out of position by the impact of the water. By directing a rootlet alternately down stream and up stream after each rheotropism has occurred, the whole root may become very zigzag. 'These facts show clearly that cer- 
tain radicles are sensitive to the impact of water, so that they turn in such a way that the irritant shall affect their two sides equally, and shall be directed against the tip. While the precise part of the radicle which is sensitive to the current has not been determined, the responding part is in the region of greatest growth, and the response is such that the root becomes concave towards the irritant.

Among animals, a response which probably belongs to this category has been observed by LoEB (91, p. 36) in the growing stem of the hydroid Eudendrium. In a vessel of water in which all other hydranths turned towards the light, there was one which rose near the cloacal opening of an ascidian, from which strong currents of water passed. This individual was turned with its concave side towards the impinging current. It is probable that the current had induced a rheotropic response.

\section{Summary of the Chapter}

The rate of growth of the entire organism or of its organs is accelerated by contact, as in the stolons of hydroids; by rough movement, as in bacteria; by cutting - when accelerated growth occurs along the cut surface. Growth in length may be retarded by pulling, as in stems and roots. Many organisms show themselves very sensitive in their growth to mechanical irritation.

The direction of growth is determined by external agents, acting as irritants, in the cases of the twining dodder, tendrils in general, roots, the hyphr of Phycomyces, the rhizoids of hepatics, and the hydranths of various hydroids. Wounding may cause a turning from the wounded side in the radicle of a seedling, and radicles and hydroids may even grow so as to face the current.

The sensitiveness to contact may be excessively great, a swinging cotton rider weighing $0.00025 \mathrm{mg}$. causing a tendril to bend. This sensitive region varies from near the tip in roots to some distance behind the tip in the case of tendrils. The response may occur after seconds, as in Cuscuta, or after hours, as in traumatropism of radicles. The bending usually reaches a maximum at the region of greatest growth. The 
stimulated condition persists for some time after irritation, so that a summation of effects may occur. An acclimatization to contact may appear, when no response is invoked by the irritation. The thigmotropic response may be explained, in general, as due to a chemical change, wrought by the one-sided impact, such as to cause a disturbance in the equality of the growth processes - assimilation, secretion, or imbibition - on the two sides of the organ.

\section{LITERATURE}

Baranetzicy, J. '79. Die tägliche Periodizität im Längenwachsthum der Stengel. Mém. de l'Acad. de St. Petersb. XXVII. $91 \mathrm{pp.}$

Buchner, H. 'S0. Ueber die experimentelle Erzengung des Milzbrandcontagiums aus den Heupilzen. Sb. k. bayer. Akad. Nuunchen. X, $368-413$.

Ciesielski, T. 772. Untersuchungen über die Abwartskrümmung der Wurzel. Beiträge zur Biologie der Pflanzen. Band I, Heft II. pp. 1-30. Taf. I.

Darwin, C. '65. On the Movements and Habits of Climbing Plants. Jour. Linn. Soc. (Bot.). IX, 1-118.

'82. The Movements and Habits of Climbing Plants. $208 \mathrm{pp} . \quad 3 \mathrm{~d}$ thousand. London, 1882. [Date of first edition, 1875.]

Darwix, C. and F. 's1. The Power of Mlovement in Plants. $592 \mathrm{pp.} \mathrm{New}$ York, 1881.

Detlefsen, E. '82. (See Chapter XII, Literature.)

Dutrocheт, H. '43. Des monvements révolutifs spontanés qui s'observent chez les végétaux. Ann. Sci. Nat. XX (Bot.), 306-329.

'44. Recherches sur la volubilité des tiges de certains végétaux et sur la cause de ce phénomène. Ann. Sci. Nat. II (Bot.), 156-167.

Errara, L. '84. Die grosse Wachsthumsperiode bei den Fruchttragern von Phycomyces. Bot. Ztg. XIII, Nos. 32 to 36. Aug., Sept. 1884.

Hegler, R. '93. Ueber den Einfluss des mechanischen Zugs auf das Wachsthum der Pflanze. Beitrïge z. Biol. d. Pflanzen. VI, 383-432.

Honvath, A. '78. (See Chapter IV, Literature.)

Jönsson, B. '83. (Sée Chapter IV, Literature.)

Leone, T. '85. Sui microorganismi delle acque potabili. Atti della R. Accad. Lincei (4) Rencond. I.

Loes, J. '91. Untersuchungen zur physiologischen Morphologie der Thiere.

I. Ueber Heteromorphose. Wuirzburg, 1891.

'92. (See Chapter X, Literature.)

MacDougal, D. T. '96. The Mechanism of Curvature of Tendrils. Ann. of Bot. X, 373-402. April, 1896.

Meltzer, S. J. '94. (See Chapter IV, Literature.) 
Монц, H. v. '27. Ueber den Bau und das Winden der Ranken und Schlingpflanzen. Tübingen, 1827.

Molisch, H. '84. (See Chapter XII, Literature.)

MülLER, O. 'S6. Untersuchungen über die Rauken der Cucurbitaceen. Beiträge z. Biol. d. Pflanzen. IV, 97-144.

Newcombe, F. C. '95. The Regulatory Formation of Mechanical Tissue. Bot. Gazette. XX, 441-448. Oct. 1895.

PALa, L. II. '27. Ueber das Winden der Pflanzen. 101 pp. 3 Tab. Stuttgart, 1827.

Peirce, G. J. '94. A Contribution to the Physiology of the Genus Cuscuta. Ann. of Bot. VIII, 53-117. Pl. VIII. March, 1894.

Pfeffer, W. '85. Zur Kenntniss der Kontaktreize. Unters. a. d. bot. Inst. Tübingen. I, 483-535.

'93. Druck und Arbeitsleistung durch wachsende Pflanzen. Abh. sächs. Ges. d. Wiss., Leipzig. XX, 235-474.

Reinke, J. '80. Ueber den Einfluss mechanischer Erschütterung auf die Entwickelung der Spaltpilze. Arch. f. d. ges. Physiol. XXIII, 431-446.

Russecl, H. S. '92. The Effect of Mechanical Movement upon the Growth of Certain Lower Organisms. Bot. Gazette. XVII, 8-15. Jan. 1892.

SAcrs, J. '73. Ueber das Wachsthum der Haupt- und Nebenwurzeln. Arb. Bot. Inst. Wuirzburg. I, 385-474.

's7. (See Chapter X, Literature.)

Schenck, H. '93. Ueber den Einfluss von Torsionen und Biegungen anf das Dickenwachsthum einiger Lianen-Stämme. Flora. LXXVII, 313-326.

Schnidt, B. '91. Ueber den Einfluss der Bewegung auf das Wachsthum und die Virulenz der Mikroben. Arch. f. Hygiene. XIII, 247.

Scholtz, MI. '87. Ueber den Einfluss von Dehnung auf das Läng'enwachsthum der Pflanzen. Beitr. z. Biol. d. Pflanzen. IV, 365-408.

Spauldixg, V. M. '94. The Traumatropic Curvature of Roots. Ann. of Bot. 423-452. Pl. XXII. Dec. 1894.

Tumas, L. '82. Ueber die Bedentung der Bewegung für das Leben der niederen Organismen. Medic. Wochenschr. 1882. No.18. St. Petersburg.

Verworv, M. '95. Allgemeine Physiologie [1st Aufl.]. 584 pp. Jena, 1895. DE Vries, H. '73. Längenwachsthum der Ober- und Unterseite sich krüınmender Ranken. Arb. Bot. Inst. Würzburg. I, 302-316.

Wiesner, J. '84. Untersuchmngen über die Wachsthumsbewegungen der Wurzeln. Sb. k. Akad. Wiss. Wien. LXXXIX'1, 223-302.

Wortmann, J. '87. Zur Kenntniss der Reizbewegungen. Bot. Ztg. XLV, 785 et seq. Dec. 1887. 


\section{CHAPTER XV}

\section{EFFECT OF GRAVITY UPON GROWTH}

\section{§ 1. Effect of Gravity upon the Rate of Growth}

IT is a result of the sessility of the higher plants that they and their parts are acted upon continuously in one direction by gravity. It might consequently be suspected that the rate of their growth would be affected if they were placed in an abnormal position with respect to this agent. In the experiments which have been made to test the correctness of this suspicion various methods have been employed. When the growth of Penicillium which is removed from gravity's action by being slowly revolved on a klinostat is compared with that of a plant under normal conditions, the former is found to be more rapid. The plant seems to reap an advantage from not having to sustain its own weight (RAy, '97). When Phycomyces is inverted, its growth is slower than in the normal position (Elfving, '80). These two experiments upon fungi indicate a considerable sensitiveness on their part to gravity. Experiments made by Elfving ('80) and Schwarz ('81), upon the growth of inverted phanerogams and those from which the action of gravity had been eliminated by the slowly rotating klinostat, as well as those which had been subjected to excessive pressure by the centrifugal machine, yielded for the most part only negative results. Upon the rate of growth of seedlings gravity has little effect.

\section{§ 2. The Effect of Gravity upon the Direction of Growth - Geotropisu}

As with contact so with gravity two classes of effects may be distinguished, which, while often producing similar results, bring them about through very dissimilar processes. The first of these is a mechanical effect due to gravity acting upon the 
growing organ as it might upon any other heavy body. The second is a vital effect, having no immediate, direct, physical relation to the cause. The first may be called false geotropism; the second, true geotropism.

1. False geotropism may be treated very briefly, since it is not a true growth phenomenon. As an example of such geotropism may be cited the downward bending of the top of a stem heavily laden with a head of seed or with fruit, or the upward growth of the long fronds of kelp in the sea on account of the buoyant effect of the dense sea water. In such cases the direction of the growth can be accounted for upon well-known principles of hydrostatics.

2. True Geotropism. - The biological effect, on the other hand, which is seen in true geotropism is often opposed to the gross physical one. It shows itself especially in various groups of sessile plants and animals. Since, unfortunately, comparatively few experiments have been made upon geotropism in animals, the great mass of our knowledge on this subject is derived from studies on plants.

The general fact of geotropism strongly impresses one who stands on the shore of a lake in our northern country and looks across to the dense pine forest on the opposite side. The landscape is composed of vertical and horizontal linesvertical lines below formed of close-set trunks of trees, horizontal lines above formed of the great branches. If at one side a steep slope ascends, its outline is obscured by the grill-work of perpendicular lines formed by the vegetation which clothes it. Here the effect - the dissimilar effect - of gravity in determining the direction of growth of two organs, trunk and branch, is seen. There are, however, still other organs which may respond to the same stimulus. Among these are the roots, flower stalks, and leaves of phanerogams; the vertical parts of many vascular cryptogams; the sporiferous hyphæ of fungi and some vertical algæ, e.g. Chara. There is no need to examine all these cases of geotropism, but only such of them as will help us to get at the principles of the action of gravity in determining the direction of growth.

a. Roots. - When a seedling is so placed that its radicle is horizontal, the radicle does not continue to grow out in the 
same direction; but all additional growth is vertical so that the radicle bends sharply downwards - it is positively geotropic. The curvature does not take place at the very tip of the root, - in the region of growth by assimilation, - but immediately behind in the region of stretching or of growth by imbibition. The precise region at which the curvature occurs was determined by Ciesielski ('72), by means of a method illustrated in Fig. 106. It is here seen that the maximum bending occurs in this radicle at between 3 and $4 \mathrm{~mm}$. from the tip. It is also plain that the geotropic curvature is in some way connected with growth-could not occur without growth.

To show that the normal vertical growth of a root is due to the pressure of gravity, KNight, in 1806, determined experimentally that the direction of its growth can be determined by other pressures replacing gravity, such as centrifugal force. Thus when seedlings were attached to the rim of a wheel and this was made to rotate rapidly about a horizontal axis the radicles grew straight outward from the axis; thus in the sense in which the centrifugal pressure acted, as before they had grown in the sense of the pull of gravity.

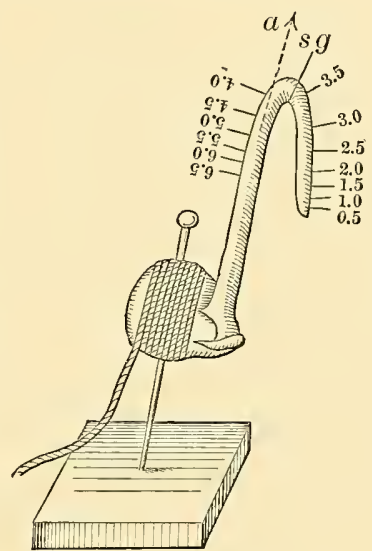

Fig. 106. - An originally straight radicle of the pea, graduated in $0.5 \mathrm{~mm}$. spaces and placed nearly vertically with its apex directed upwards in the direction of $a$, has turned downwards in the zone of greatest growth at between 3.5 and 4 mm. from the tip. (From CreSIELSKI, '72.)

A second method of proof, employed by SAcHs ('79), consisted in eliminating the effect of gravity by means of the klinostat (Chapter V, $\S 1$ ), under which circumstances the root grew irregularly. Such results leave no room for doubt that it is gravity which determines the verticality of the root.

The question now arises, in what way does gravity control the direction of growth of this organ? An early suggestion was that the action was direct, due to the relatively great specific gravity of the root tip; but this idea was easily refuted by a mass of evidence. Thus it is not, a priori, easy to see 
how the mere weight of the tip of the plant, supported as it is by the firm soil, should enable it to find its way down. Experiments, also, have shown that the radicle will curve downwards against considerable resistance such as is afforded by the surface of a cup of mercury, by a weight which is lifted by means of a thread passing over a pulley (Johnsos, '29), or by a delicate syring which is compressed by the down-curving radicle (W ACHTEL, '95). By these various methods it has been demonstrated that the down-curving of the geotropic radicle is an active process capable of overcoming resistance amounting, in one case, to 150 milligrammes. Consequently gravity does not act in a grossly mechanical way, but as a stimulus inciting a growth response.

If now the down-curving of the root is a response the question arises, where is the stimulus received; at the region of curvature or at some other point? This is a question which has excited much discussion, owing to apparent contradictions in the experimental evidence. The first attempt to answer this question was made by Ciesielsik * (72), who cut off the terminal one-half millimeter of the radicle, placed the rootlet in a horizontal position, and found that, although growth continued, no down-curving occurred until, after several days, the root tip had regenerated. He concluded that the root tip is useful or necessary in geotropism. SAcHs (73, p. 433) repeated Ciesielski's experiments and likewise found an incomplete exhibition of geotropism. But this he attributed to the excessive irritation of the cutting, which led to exaggerated movements of nutation, tending to obscure geotropism. DARWin ('80) confirmed Ciesielsiki's results after both cutting off the root apex and cauterizing it, and explained SACHs' partial failure to get like results on the ground that he did not amputate the radicles in a strictly transverse direction. DARWIN concluded that the "tip of the radicle is alone sensitive to geotropism, and that when thus excited it causes the adjoining parts to bend." The exact length of the sensitive part seems to vary with certain conditions, but it is generally less

* HARTig ('66, p. 53) had already stated that the decapitated root was not geotropic. 
than 1 to $1.5 \mathrm{~mm}$. This terminal millimeter or so, then, acts like a sense organ in a vertebrate, which receives the sensation at some distance, it may be, from the responding organ.

From this time on, two schools may be distinguished, of which the first, following DARwIN, regarded the stimulus as received at the root tip and transmitted to the region of growth; while the second conceived the stimulus to act directly upon the root in the bending region and to arise from the difference in the pressures on the upper and lower surfaces of the radicle. The second school persistently denied the validity of the decapitation experiments, WIESNER ('81) in particular maintaining that decapitation inhibited growth and consequently growth curvatures, but did not necessarily remove the sensitive organ. The first school was forced to new experiments. Francis DARwin ('S2) maintained on the basis of such experiments that it is not the cutting per se which inhibits geotropism; for the cutting of the root tip, as for example, lengthwise, without its removal, permits the normal response. But it was easy to reply to this that a transverse cut might well affect growth more seriously than a longitudinal one.

The satisfactory solution of this difficulty required a method by which, without mutilating the root, gravity should act horizontally upon the chief growing part of the root without so acting upon the root tip. A method for accomplishing this was invented by PFEFfer ('94). A radicle of a bean or other species, fixed to a klinostat, was made to grow into a small glass tube, closed at its further end and bent so as to form two arms, at right angles to each other, and each about 1.5 to $2.0 \mathrm{~mm}$. long. The preparation was now turned until the root tip was directed vertically downwards, while the rest of the root, and especially its ehief growing region, was horizontal (Fig. 107). This region was then subjected to the full transverse action of gravity, while the tip was not so acted upon. Meanwhile the normal growth

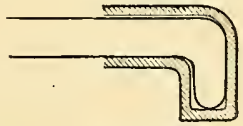

FIG. 107. - Diagram illustrating the method employed in PFEFFER's experiment.

processes were not interfered with, for as the root lengthened it backed out, so to speak, from the bent tube, the apex remain- 
ing at the blind end. Under these conditions no geotropic curvature occurred; but such eurvature always took place when the root tip was placed horizontally or at any acute angle with the horizon. This experiment seems, then, better fitted than any previous one to prove that the geotropic sensitiveness of the root resides in the apex.* Consequently, since, as an inspection of Fig. 106 will show, the curving part of the root can contain none of the originally irritated cells, there must be a transmission of stimuli from the root tip to the curving region.

Two associated phenomena remain to be considered. First, geotropic response is more powerful, the bending becomes stronger, as the angle made by the root with the vertical increases, reaching a maximum when the root is horizontal (SACHs, '73, p. 454). Secondly, as already indicated, response does not take place immediately after the root is placed horizontally. In one experiment of SACHS' ('73, p. 440) a bean radicle placed horizontally and growing in loose earth at $20^{\circ} \mathrm{C}$. began to turn downwards in the second hour. There is thus a considerable latent period.

The cause of geotropism in roots is indicated by the conditions of its occurrence already mentioned. It is intimately associated with growth, yet, as KIRcHNer ('82) has shown, it may occur at a temperature $\left(2^{\circ}\right.$ to $3.5^{\circ} \mathrm{C}$.) at which growth is extremely slow. The turning is clearly due to unequal growth upon the convex and concave sides of the root. But is it due to acceleration on the convex side over the normal, to retardation on the concave side, or to both? Measurements have been made upon plants to decide this question. In one set of such measurements made upon the bean radicle by SACHS ('73, p. 463) the growth was hastened about $3 \%$ on the convex side and retarded $42 \%$ on the concave side, so that both acceleration and retardation occur.

Finally, lateral roots which run more or less obliquely downwards have been shown by SAcHs ('74) and others to be influenced by gravity; for, if the plant be inverted, the roots will turn until they assume their normal inclination to the horizontal plane.

* But species may differ in this respect as in phototropism (see page 441). 
b. Stems. - The central fact that the upward growth of stems is determined by gravity is established by the observations that on the klinostat no definitely directed growth occurs, and that on the centrifugal machine the stem turns in the opposite sense to that of the centrifugal pressure. The stem is negatively geotropic. As with roots, so with stems, a number of questions now arise: Where is the sensitive region and where the response? At what inclination of the stem is the strongest geotropic curvature called forth? What is the immediate cause of the curvature?

As Fig. 108 shows, the response of the stem of a seedling is fundamentally different from that of the radicle. Instead of the tropism beginning at one point, and continuing there as in the root (Fig. 106), it begins close below the cotyledons of the seedling and passes downwards towards the base as far as growth is still occurring. Response, consequently, takes place along the whole "stretching" region. The sensitive region also, unlike that of the root, is not confined to the tip, but extends along the entire bending stem.

The position in which the strongest response is incited was believed by SAchs ('79a, p. 240) to be the horizontal one, and BATEson and Darwin ('88) have confirmed this conclusion. Their method depends upon the fact that a stem placed horizontally and restrained for several hours from taking the vertical position will, upon being released,

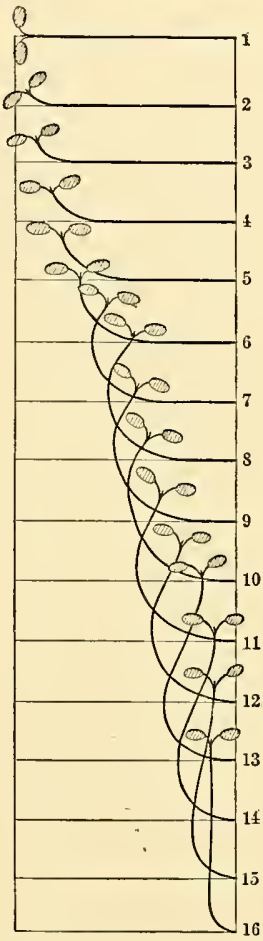

FIG. 108. - Course of geotropism in a plumule. The successive figures 1 to 16 indicate successive stages in the geotropic turning of a seedling growing in half darkness. Placed at first horizontal as at 1 , the plant has become completely erect at 16. The most rapid growth is just behind the cotyledons and diminishes toward the base. The temporary bending beyond the vertical is to be noted. (From STrasBUrger, Noll, Schenck, and Schimper, Textbook of Botany, Macmillan.) suddenly spring upwards. In using this method it was found that the stem springs through a greater are after having been 
restrained for two hours in a horizontal position than if restrained in any oblique position, whether the tip be directed up or down.

Concerning the canse of the curvature there is little to add to what was said under "Roots." The remote cause is apparently the dissimilar action of gravity on the upper and the under sides of the stem; the immediate cause is the difference in growth on the two sides of the stem. In the special case of stems with knots, the knots show themselves especially responsive to the geotropic stimulus.

c. Rhizoma. - These horizontally running, root-like, subterranean stems are strikingly responsive to gravity, as ELFVING ('80), especially, has shown. He has reared various rushes in a glass box with their axes making various angles with the vertical. In their subsequent growth all the rhizomes of the plants extended in a strictly horizontal direction. In this case any component of gravity, however small, running in the direction of the axis of the rhizome seems to irritate. The curving into a horizontal plane may be called transverse geotropism (diageotropism, FRANK).

d. Cryptogams. - We have already seen (p. 391) that the sporangiferous hyphæ of Phycomyces nitens are negatively geotropic. The same is true of certain algæ. Thus Richter ('94) has found that when the stem of Chara is inverted the youngest two or three internodes curve upwards in their further growth so that the apex of the stem is now directed zenithwards. On the other hand the rhizoids of this species are positively geotropic. Rotation experiments show that in the absence of the directive pressure of gravity there is no definite orientation. Finally, some mosses are slightly geotropic. Thus, Bastit ('91) reared Polytrichum juniperinum in the dark in both air and water, some plants being placed right side up, others inverted. In both cases new branches budded from the roots and, although etiolated, grew irregularly upwards - there was a feeble negative geotropism.

e. Animals. - Since only sessile organisms can be expected to show marked geotropism, this phenomenon among animals must be confined to rather few groups. It has been studied hitherto exclusively in the group of hydroids. Many repre- 
sentatives of this group show themselves, however, markedly responsive.

The first observations upon geotropism in hydroids seem to have been made by Loes ('91'a pp. 27, 28). He says : "When a stolon was formed at the cut end of a vertical stem (of Aglaophenia) it grew (in case it did not come in contact with a solid body) first a short distance horizontally, and then downwards. In horizontal stems the stolon grew directly down-
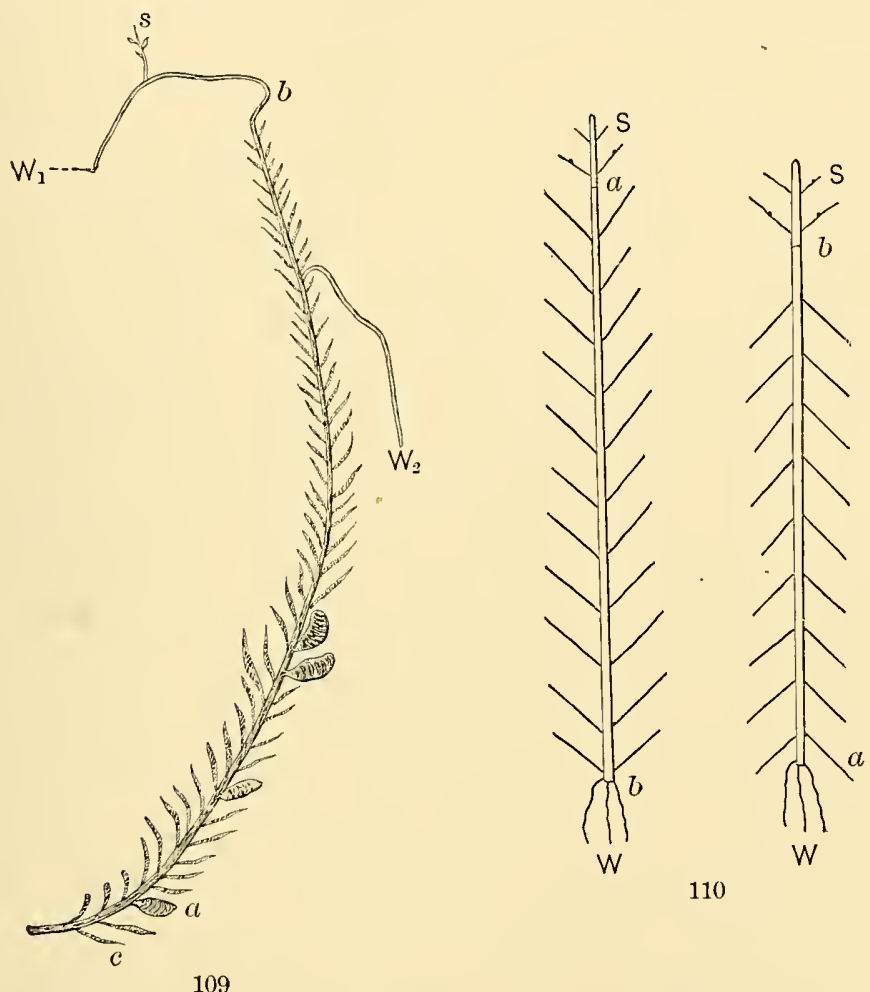

110

FIG. 109. - Positive geotropism of regenerated stolons $\left(W_{1}, W_{2}\right)$ and negative geotropism of regenerated hydranths of Aglaophenia pluma. The original piece of the stem is included between $b$ and $c$. This piece was placed vertically, right end up, in the aquarium. At the cnt end, $b$, the stolon $\left(W_{1}\right)$ has arisen, but has soon begun to grow downwards. It has prodnced a vertical hydranth at $s$. $W_{2}$, an adventitions stolon. (From LoEs, '91 ${ }^{\text {a }}$.)

Fig. 110. - Two bits of regenerating stems of Antenuularia antennina. The one at the left is in the normal position; that at the right is inverted. From both, new hydranths (S) have developed at the npper end, and new stolons (W) at the lower end. (From Loeb, '92.) 
wards." "Adventitious stolons grew directly downwards towards the earth. This was most noteworthy when such adventitious stolons arose from a reversed stem (with the apex down) sticking in the sand; under these circumstances the stolon grew towards the apex. These descending stolons showed occasionally twistings and curlings, such as are found in tendrils. The newly arising sprouts [hydranths] behaved in the reverse fashion from the stolons: they grew vertically upwards" (Fig. 109). Subsequently, LoEb ('92, p. 8, '94)

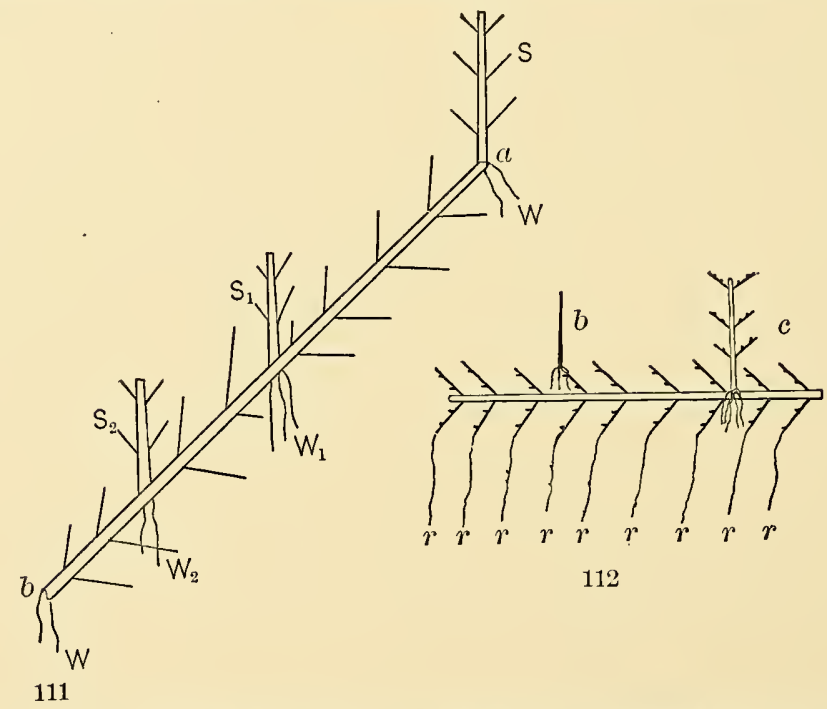

FIG. 111. - A bit of regenerating stem of Antennularia antennina placed in the water obliquely, with the basal end downwards. The new hydranths $(S)$ and stolons (W) arise vertically. (From Loes, '92.)

FIG. 112. - A piece of the stem of Anteunularia placed horizontally, and regenerating stolons $(r, r)$ downwards, and hydranths $(b, c)$ upwards. (From Loks, '94.)

found another hydroid, Antemnularia, which, whether the stem was held inverted, oblique, or horizontal, sent out new stems, which grew vertically upwards, and stolons, which grew vertically downwards (Figs. 110, 111, 112). The growing stolon, if moved out of its first position, will curve until it acquires again its vertical direction. The geotropism of stolons has been likewise carefully studied by Driesch ('92). This author found in a species of Sertularella that, although the main stolons are not geotropic, the daughter (secondary) sto- 
lons are markedly negatively geotropic. As the following figure shows (Fig. 113), it is only the newly growing part which exhibits this geotropism. These geotropic movements
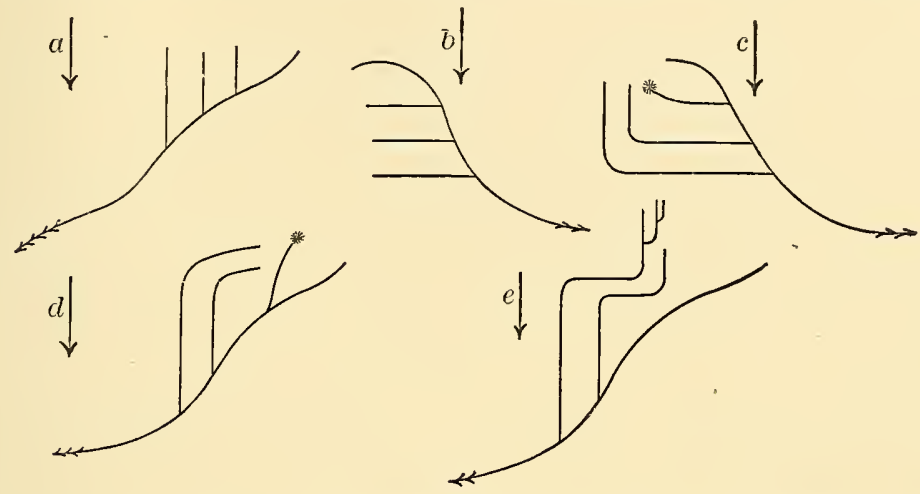

Fig. 113. - Diagrams of a Sertularella stock, showing how the direction of growth is determined by gravity. The arrow points towards the earth's centre. The stock originally placed in the position $a$ is subsequently reversed as at $b$, and again as at $d$. The asterisk indicates a hydranth. (From Driesch, '92.)

in animals, which occur near the growing apex, are clearly due to unequal growth on the two sides of the inclined stem or stolon.

Many untouched questions on geotropism in animals arise for solution - questions about the location of the perceiving and the responding portions of the stem, latent period and after effect, and others. Especialiy is it desirable to find how wide-spread the geotropic phenomena are in sessile animals.

f. After-effect in Geotropism. - When a root or stem is placed horizontally, and retained in that position for a part of its latent period, and then, before the curving has appeared, is rotated on its long axis through $180^{\circ}$, the turning takes place at about the time and towards the same side as it would had the organ been left undisturbed; in its new position the root turns up, and the stem, for the moment, down. The response, once set in motion, works itself out, until finally annihilated by an opposing response (Hofmeister, '63 ; Ciesielski, '72).

This experiment has been variously modified in ways which throw light on the meaning of the after-effect. It has repeatedly been observed that if the root tip be decapitated before 
the end of the latent period the geotropism will occur in the normal manner. The impulse once transmitted, the geotropic function of the root tip is finished. Again, SACHS ('74 ${ }^{\text {a }}$ laid a stem in a horizontal position for an hour or two, until upcurving had commenced near the tip. The tip was now held horizontal, and for from one to three hours, during which stretching took place, the horizontal part grew horizontally, while the new tip turned zenithwards. The tip in turning determines the direction of the incipient stretching zone, and the stretching continues in this direction without regard to subsequent changes in position of the stem. The stretching is independent of any control on the part of the tip.

Other conditions of geotropic after-effect have been determined by Wortuans ('st). He treated a stem according to SAcHs' method, and placed it in a chamber filled with hydrogen. Growth ceased. After oxygen was readmitted the tip turned up at once, but no after-effect appeared. This had been annihilated by the absence of oxygen. If, however, the stimulated sprout was placed vertically in de-aërated water, there was an after-effect, but no geotropic response. So we may conclude that, in the absence of oxygen, the geotropic response will not occur: and that an after-effect may occur if the stretching tissue is bathed with water for imbibition, but not under other conditions.

\section{SuMMrary}

The rate of growth seems to be little affected by the absence of gravity or the abnormal condition of its action, except in some of the higher fungi, where the removal of gravity hastens growth, and its abnormal direction retards. Geotropism is found only in sessile organisms. In roots the turning occurs in the region of greatest growth, and the tip alone is sensitive to gravity's action. The response is preceded by a latent period, and is strongest after the root has been placed horizontal; it is due, in the case of both roots and stems, to an acceleration of growth on one side and its retardation on the other. In plumules the turning begins near the tip and proceeds towards its base; the whole bending region is responsive 
as well as sensitive. Many cryptogams show negative geotropism. Many branches and rhizomes show transverse geotropism. Among animals, hydroids show negative geotropism. A marked after-effect follows negative stimulation, by means of it we can show that stretching or the geotropic curvature are independent of any control from the tip after once the stimulus has been transmitted to the stretching region. Like other responses to stimuli, geotropism does not occur in the absence of oxygen.

\section{LITERATURE}

Bastit, E. '91. Recherches anatomiques et physiologiques sur la tige et la feuille des mousses. Rev. Gén. de Bot. III, 255 et seq.

Bateson, Anna, and Darwix, F. 'S8. On a Method of Studying Geotropism. Ann. of Bot. II, 65-68. June, 1888.

Ciesielsiki, T. '72. (See Chapter XIV, Literature.)

Darwin, C. 'so. (See Chapter XII, Literature.)

Darwin, F. '82. On the Connection between Geotropism and Growth. Jour. Linn. Soc. XIX, 218-230.

Driesch, H. '92. Fritische Erörterungen neuerer Beiträge zur theoretischen Morphologie. II. Zur Heteromorphose der Hydroidpolypen. Biol. Centralb. XII, 545-556. 1 Oct. 1892.

Elfvivg, F. '80. Beitrag zur Kenntniss der physiologischen Einwirkung der Schwerkraft auf die Pflanzen. Acta Soc. Scient. Fennicæ, Helsingfors. XII, 25-58.

' $80^{\text {a }}$. Ueber einige horizontal wachsende Rhizome. Arb. Bot. Inst. Würzburg. II, 489-494.

Hartig, T. '66. Ueber das Eindringung der Wurzeln in den Boden. Bot. Ztg. XXIV, 49-54. 16 Feb. 1866.

Hofmeister, W. '63. Ueber die durch die Schwerkraft bestimmten Richtungen von Pflanzentheilen. Jahrb. f. wiss. Bot. III, 77-114.

Jornson, H. '29. The Unsatisfactory Nature of the Theories proposed to account for the Descent of the Radicles in the Germination of Seeds shewn by Experiments. Edinb. New Philos. Jour. April, 1829. 312-317.

Krrchner, O. '82. Ueber die Empfindlichkeit der Wurzelspitze für die Einwirkung der Schwerkraft. Prog. zur 64. Jahresfeier d. k. Württemb. Landwirths. Akad., Hohenheim. 53 pp. Abstr. Bot. Centralb. XIII, 180-183.

Knight, T. A. '06. On the Direction of the Radicle and Germen during the Vegetation of Seeds. Phil. Trans. London for 1806. pp.99-108.

Loeb, J. '91. Ueber Geotropismus bei Thieren. Arch. f. d. ges. Physiol. XLIX, 175-189. 
'91'. Untersuchnugen zur physiologischen Morphologie der Thiere. I. Ueber Heteromorphose. $80 \mathrm{pp}$. Taf. Wuirzburg, 1891.

'92. Untersuchungen zur physiologischen Morphologie der Thiere. II. Organbildung und Wachsthum. Würzburg: G. Ilertz. $81 \mathrm{pp}$.

'94. On Some Facts and Principles of Physiological Morphology. Biol. Lectures, Wood's Holl Laboratory, 1893. pp. 37-61.

Pfeffer, W. '94. Geotropic Sensitiveness of the Root-tip. Ann. of Bot. VIII, 317-320. Sept. 1894.

RAY, J. '97. Variations des champignons inférieurs sous l'influence du milien. Rev. Gén. de Bot. IX, 193-212, 245-259, 282-304. JuneAug. 1897.

Ricuter, J. '94. Ueber Reaction der Characeen auf äussere Einflüsse. Flora. LXXVIII, 399-423.

Sachs, J. '73. Ueber das Wachsthum der Haupt- und Nebenwurzel. Arb. Bot. Inst. Würzburg. I, 385-474.

77. The same, continued. Arb. Bot. Inst. Wiirzburg. I, 584-634.

$74^{a}$. Ueber Wachsthum und Geotropismus aufrechter Stengel. Flora. LVI, 320-331.

79. Ueber Ausschliessung der geotropischen und heliotropischen Krümmungen während des Wachsens. Arb. Bot. Inst. Würzburg. II, 209225.

79a. Ueber orthotrope und plagiotrope Pflanzentheile. Ibid. pp. 226284.

's7. Vorlesungen über Pflanzen-Physiologie. 2 Aufl. Leipzig: Engelmann. 884 pp. 1887.

Schwarz '81. Der Einfluss der Schwerkraft auf das Längenwachsthum der Pflanzen. Unters. Bot. Inst. Tübingen. I, 53-96.

Wachtel, MI. '95. Einige Versuche betreffend die Frage über die geotropischen Krümmungen der Wurzeln. Abstr. in Bot. Centralb. LXIII, $309,310$.

Wiesner, J. '81. Bewegungsvermögen der Pflanzen. Wien, 1887.

Wortmany, J. '84. Studien über geotropische Nachwirkungserscheinungen. Bot. Ztg. XLII, 705-713. 7 Nov. 1884. 


\section{CHAPTER XVI}

\section{EFFECT OF ELECTRICITY ON GROWTH}

\section{§1. Effect of Electricity upon the Rate of Growth}

ELECTRICAL changes are so intimately associated with chemical changes that we may reasonably expect not only to find that the metabolic processes of growth are accompanied by the development of electricity, but also to find that an electric current disturbs growth. It is indeed known that electricity is produced in seedlings, for MüLler-Hettlingex ('83) has obtained from a seedling of Vicia faba by connecting the two extremities a maximum electromotive force of about one-tenth of a volt. (Fig. 114.) There is thus in the living plant an electric stress. Will an outside current, which must affect that of the organism, disturb also its growth?

In the case of the growing animal even a slight current of electricity is usually injurious. Thus Lombardini ('68) and WINDLE ('93 and '95) have subjected the egg of the chick to such a current rumning transversely through the embryo, with the result that the embryo either soon ceased to develop or devel-

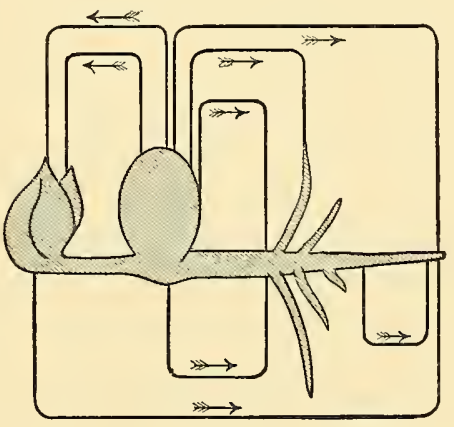

FIG. 114. - Vicia seedling. The lines uniting different points of the seedling may represent the wires running to the galvanometer; the points themselves are those from which the current was led off ; the arrows go with the currents in the wires. (From MǗller-HetTlingen, 'S3.) oped abnormally. Rusconi ('40), on the other hand, believed that a slight current accelerated the development of the frog's egg. More extended experiments with known strengths of currents are much to be desired.**

* Certain unconfirmed results with a powerful magnet deserve to be noted. Maggionini ('84) found that developing hens' eggs subjected to this agent produced four times the normal number of cases of arrested development. 
Upon growing plants, on the other hand, numerous experiments have been made. Nevertheless there is still a difference of opinion even as to the occurrence of any effect. During the middle of the last century much attention was paid to this subject. Bertheron (1783) and several others concluded from extended researches that electricity favors plant growth; but their results, apparently having no practical value, were largely forgotten. A century later GraNDEAU ('79) revived the idea of the beneficial effect for plants, not merely of currents of electricity, but also of those of the atmosphere. This paper seems to have been the starting-point of the modern discussion.

The methods employed in studying the action of electricity
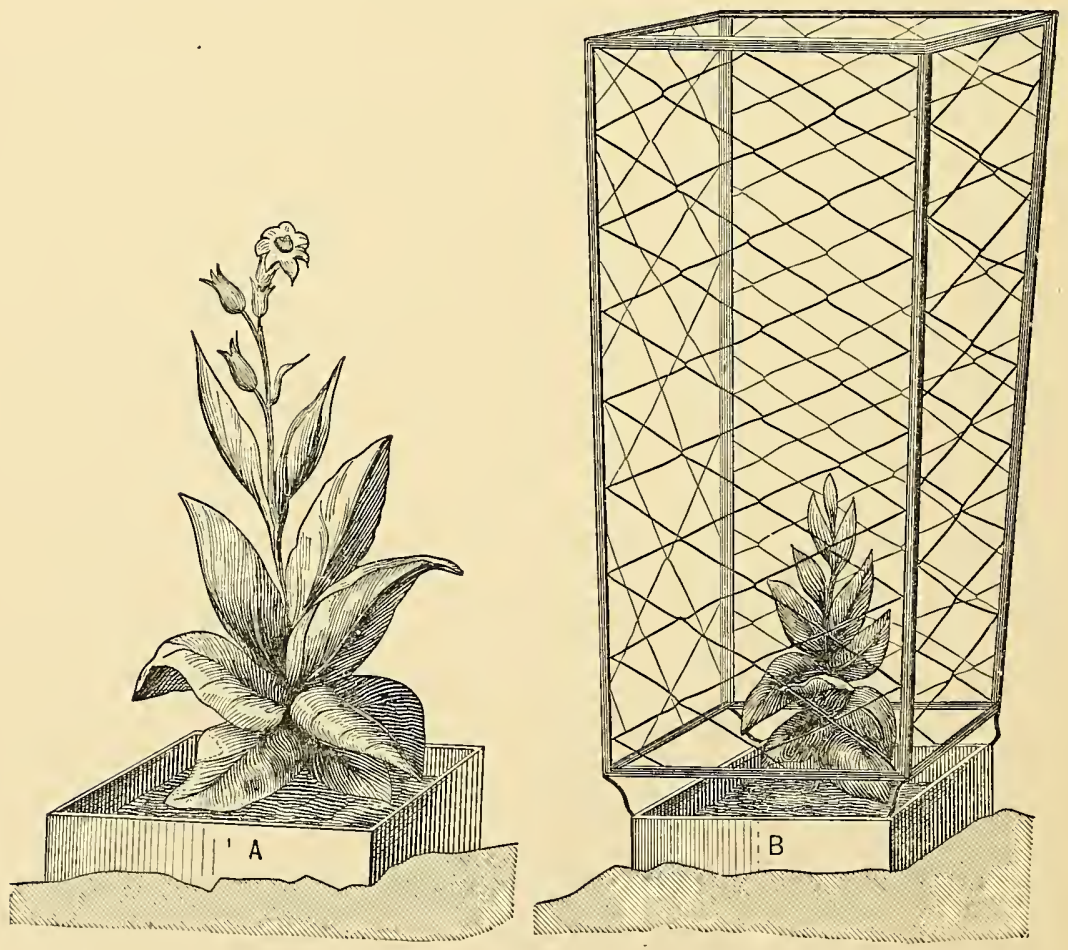

Fig. 115. - The effect of atmospheric electricity upon the growth of plants. $A$, Tobacco plant reared under normal conditions. $B$, Similar plant reared under a wire cage, by means of which it is isolated from the action of atmospheric electricity. (From GrandeAU, '79.) 
have been of two general kinds. On the one hand the seedling is electrified by passing a current through the soil in which it is growing and after several days comparing it with an untreated seedling. On the other hand the tension of the atmospheric electricity is altered either by electrifying the air of the chamber in which a plant is growing, or by isolating a plant from the action of atmospheric electricity by means of a eage made of fine wire and with meshes so wide that a minimum amount of light is cut out (Fig. $115 A$ and $B$ ).

The method of passing a current through the soil has been employed by WARren ('89), Chodat ('92), McLeod ('93 and '94), and by other investigators with results favorable to the plants. McLeod passed the current transversely. He sunk plates of metal on either side of the pea seeds employed in the experiment and used a current from a single cell. While the control seedlings germinated somewhat earlier than the electrified ones, at the end of 45 days the latter had ontstripped the former. Again, a coil of wire, partly stripped of its insulation, was imbedded in the ground, and from a lot of similar mustard seeds some were placed next to the uncovered wire and others about one inch away from the insulated part of the wire. A constant current was sent through, and at the end of seven days the seedlings planted near the uncovered wire were one-third larger than the others. CHODAT used a current passing lengthwise through the plant. Similar beans were divided into two equal lots and each was reared in glass cylinders under similar conditions, except that one was melectrified while the other was electrified by the following method. The cylinder rested on one armature of tin-foil while the other was suspended 1.8 meters over the first. The armatures were connected with a Holtz machine and a current was passed through the cylinder for about three hours each day. The result was that on the fourth day leaves began to show on the electrified seedlings but not on the control ones, and on the seventh day all the electrified seedlings had attained considerable size, whereas the control ones were just making their appearance. The electrified seedlings were spindling, however, much as if reared in the dark. IVARrex's experiments are noteworthy in that he found the seedlings which 
were nearer the positive electrode more advanced than those which were nearer the negative electrode.

'The method of electrifying the air over the plants was employed by Celi ('78), FredA ('88, on Penicillium), and Lemströм ('90). Their methods were somewhat dissimilar: Cesl discharged static electricity through a wire breaking up into fine points over the growing seedlings and got increased growth; Freds used a similar method with Penicillium reared on bread but obtained no favorable effect; Lemsteöм conducted his experiments upon a larger scale, since he covered a small part of a field of germinating barley with fine parallel wires about a meter apart, provided with metal points at intervals, and supplied with a current from a Holtz machine during eight hours a day for over two months. In Lexströr's experiments the yield of the electrified field was $35 \%$ in excess of that of the unelectrified, and the quality of the grain was better. These experiments, which extended through several years, were carried on in various parts of Scandinavia and in France, and generally resulted in a favorable effect upon the growth of malt crops.

The method of eliminating atmospheric electricity was used with success by GrandeaU ('79), who employed the method of isolating seedlings in a wire cage referred to on p. 407. The plants reared in the wire cage grew uniformly less rapidly than similar plants reared outside. ALor ('95) has confirmed these results with the same method, using maize and bean seedlings.

On the other hand other investigators, preëminently WoLLNy ('93), who used the methods both of increasing and of eliminating atmospheric electricity, obtain only negative results. Thus the whole matter stands, rejected on a priori grounds by many, denied as a result of negative experiments by others, but still apparently demonstrated by three lines of experimentation, none of them, however, free from criticism. There prevails a cautious scepticism concerning the validity of the positive results obtained.

Various explanations have been offered by those who accept the positive results. Freda, who found that Penicillium is injured by the increased atmospheric electricity, attributed that 
injury to the greatly increased amount of ozone that appeared in his vessels. In the open air, on the other hand, the increase of ozone would be relatively so slight that it might well be advantageous to growth. WARREN's results would then be accounted for by the fact that the ozone is especially produced at the positive pole, thus favoring for a time the excessive growth at that pole. On this explanation the electricity would act only indirectly. Somewhat similar is the conclusion of Thouverin ('96), that the electric current aids the plant in its decomposition of carbon dioxide. On the other hand there is reason for believing that since plants are adjusted to an (internal) electrical condition, a slight external one might be advantageous rather than injurious.

\section{§ 2. Effect of Electricity upon the Direction of Growth - ElectrotropisM}

In 1882 the Finnish botanist Elfving announced his discovery that when the radicle of the seedling of a bean or of certain other species was subjected in water to a transverse current of electricity, it grew towards the anode. This was the introduction to a series of interesting studies on what has been called electrotropism. In classifying the data which have been acquired we may make use of the following heads: 1. False and True Electrotropism; 2. Electrotropism in Phanerogams; 3. Electrotropism in Other Organisms ; 4. Magnetropism; and 5. Explanation of Electrotropism and Summary.

1. False and True Electrotropism. - ElFving himself observed two opposing phenomena in the seedlings which he subjected to the current. In most cases the radicles grew towards the anode, but in one species, Brassica oleracea - the wild cabbage - the radicle grew towards the kathode. ELFVING was inclined, in consequence, to believe that some species respond by growth in one direction and other species by the opposite growth; that these are diverse responses to the same agent, just as negative and positive chemotropism are. Gradually, however, it became evident, chiefly through the work of Müller-Hettlingex ('83) and especially Brunchorst ('84, '89), that these results are due to dissimilar causes. Thus 
Brunchorst ('84, p. 209) found that the radicles of seedlings of Brassica grow, under otherwise similar conditions, at a current intensity* of $0.03 \delta$ to $0.05 \delta$, towards the kathode, and at a current intensity of $3.0 \delta$ towards the anode (Fig. 116).
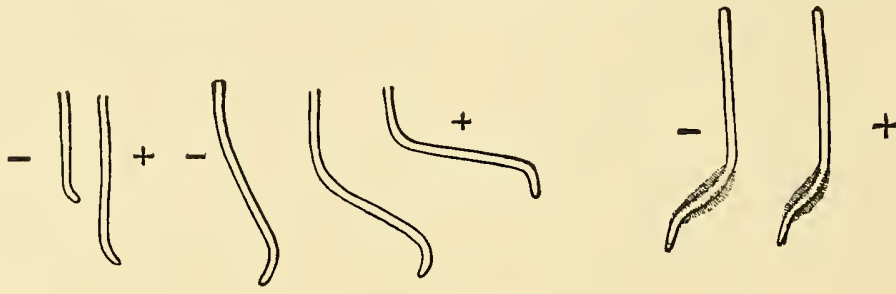

BRASSICA

Fig. 116. - Effect of different strengths of electric current on the radicle of Brassica. At the right: strength of current, $1.1 \delta$; all strongly negative and growing well. At the middle: strength of current, $1.8 \delta$; after a few hours negative at the apex but positive higher up. At the left: strength of current, $3.1 \delta$; all positive, weak, and dead. (From Brunchorst, '84.)

If decapitation has occurred the kathode turning does not follow, whereas the anode turning does occur as in the intact root. A similar result having been obtained with seedlings of various species, the conclusion was drawn that "the positive galvanotropic curving is a simple chemico-pathological phenomenon which has only a superficial analogy with the directive movements of roots, and therefore does not deserve the name galvanotropism" [electrotropism].

The cause of the positive turning effect, it has been suggested, lies in the fact that certain substances, perhaps hydrogen peroxide and ozone, produced in electrolysis act more injuriously upon the positive than upon the negative side. According to another explanation, offered by Rischawi ('85), the positive curvature is due to the kathophoric action

* The current density (see Chapter VI, $\S 1$ ) is calculated from the following data: The amount of copper deposited in a voltameter was $0.14 \mathrm{mg}$. to $35 \mathrm{mg}$. per hour during the course of experimentation. A current of one ampere intensity deposits 0.000326 gramme of copper per second or $1.17 \mathrm{mg}$. per hour per milliampere. Thus the strength of current varied from 0.12 to 30 milliamperes. The determination of the density requires a knowledge of the cross-section over which the current spread itself. For this we may take the given area of the electrodes, 6499 sq. $\mathrm{mm}$., which is not far from the crosssection of the trough. 
of the current.* DuBors-Rerroxp had found that when a current was passed through a cylinder of hard-boiled albumen it became concave towards the anode owing to the passage of water into the plant and its aggregation at the kathode side. Rischawi found that a cylinder of plant tissue did the same, and he attributed this result as well as that seen in the living radicle to the accumulation of water at the kathode side. But, as Bruxchorst points out, this is not the whole explanation, for the positive curving is generally accompanied by death of the tissue, and death would not necessarily result from the kathophoric action. By the use of a transverse partition of porous clay Bruxchorst ('89) has been able to show that the radicles in the positive half of the ressel are much more seriously affected than those in the negative half, which fact the kathophoric theory will not explain, but the chemical theory will (Fig. 117). In accordance with the view that the positive reaction is not a reaction to stimulus, but is a false electrotropism, it will be henceforth neglected. The negative reaction, on the contrary, is a response to stimulus - a true electrotropism.

\section{Electrotropism in Phane-} rogams. - We have seen that the transverse electric cur-

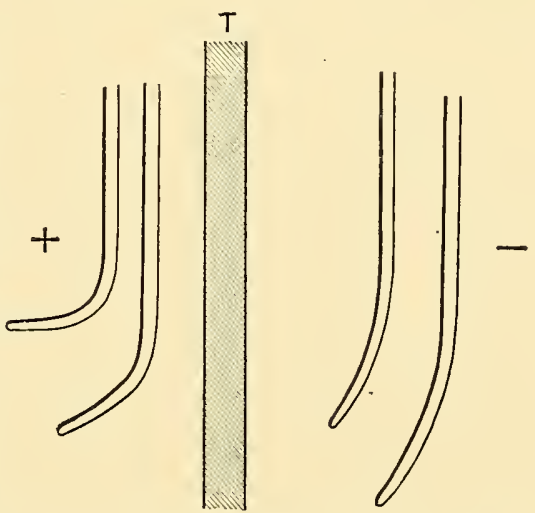

FIG. 117. - Radicles of Phaseolus on opposite sides of a partition, $T$, subjected to a transverse electric current, of $6.5 \delta$ intensity, for two hours. On the positive side of the partition all the roots are strongly positive; on the negative side, where the water is being continually renewed, the roots are slightly positive, being bent less than $40^{\circ}$. (From BRUNCHORst, '89.) rent, when not too strong, causes a turning of the tip of the seedling from the anode. That this turning is a growth phenomenon is indicated by the fact that it takes place a few millimeters behind the tip in the region of maximum growth. This is then the region of response.

* The kathophoric action is seen when an electric current passes perpendicularly through a porous partition submerged in water. The liquid moves through the partition towards the kathode (hence called also electrical endosmosis). 
The location of the sensitive region has been demonstrated by various methods. MüLLER-HETTLINGEN placed the tip only of a radicle in contact with moist flannel through which the current was passing; the radicle turned from the anode. Also Brunchorst ('8t) found that when merely the apex was in contact with the electrified water there was a marked turning from the anode, even when the current was so powerful as to canse the submerged root to turn towards the anode. 'The tip is sensitive. Next Brunchorst cut off the tip and found that no response occurred when the current traversed the radicle. Hence the tip is necessary to response, and it may be concluded provisionally that as in geotropism so in galvanotropism the root tip is the only sensitive part of the radicle.

The critical point at which the electrotropic effect passes into the mechanical one is indicated by a sigmoid turning of the radicle. According to Brunchonst's observations this critical point lies, at a temperature of $20^{\circ}$, for Phaseolus seedlings near $1.2 \delta$; for Helianthus near $1.3 \delta$; for Lupinus, $2.5 \delta$; for Brassica, $3 \delta$; for Lepidium, $3.5 \delta$. These results indicate that the different species have a diverse sensitiveness to the electric current, so that an intensity which causes the radicle of one species to turn from the anode will cause the other to turn towards it (false electrotropism).*

3. Electrotropism in Other Organisms. - While the stolons of hydroids, Bryozoa, and tunicates offer an excellent opportunity for experiments on electrotropism in animals, results have been obtained, so far as I know, outside the group of phanerogams only in the mold Phycomyces. Hegler ('92) has subjected this organism not to the ordinary electric current, but to Hentz' electric waves. $\dagger$ The result was that, after exposing to the radiant electricity for from three to six hours, the sporangiferous hyphæ curved markedly from the source of

* We can now easily understand why ELFviNg obtained, with approximately the same current, a positive curvature in many species, but a negative one with Brassica. As the list just given shows, the critical point in Brassica lies high.

$\dagger$ These were obtained by reflecting, by means of a parabolic tin reflector, the radiant energy upon the stems of the fungi. The latter were covered with a pasteboard box, to keep out light, and the whole experiment was performed in a darkened room. The fungi were experimented with when about 8 to 10 cm. long, a period when they are most sensitive to light. 
the rays in the same fashion, but not so powerfully, as they would have curved from light. Thus, electric waves produce in Phycomyces a negative electrotropism.

4. Magnetropism. - It was stated in an earlier chapter* that magnetism has no clearly established effect upon protoplasm. The alleged effect on growth is, consequently, worthy of attention. ToLoner ('93) placed over a glass vessel containing germinating peas a large horseshoe magnet, comnected with a battery composed of eight Daniell cells. The germinating organs bent away from the centre of the magnetic field ; by an appropriate position of the magnet the roots might be forced to grow upwards. ToLomer also asserts that young plants are diamagnetic, i.e. tend to place their long axes at right angles to the lines of force of the magnet. These results are interesting enough to deserve confirmation.

5. Explanation of Electrotropism and Summary. - Is electrotropism the direct result of the current, or is it, like the effect upon the rate of growth, an indirect result, due, for instance, to chemical agents produced by the current? If the action is indirect, it may be either of a mechanical or of a chemical nature. RIschawi, who proposed the very clever explanation of positive curvature on the ground of katophoric action, offered a similar explanation for negative electrotropism. He finds that a cylinder made of coagulated yolk, and placed in the water transverse to the current, bends at first convex to the anode, owing to the more rapid diffusion at first of water into that side; but, later, when the whole mass becomes permeated, it bends so as to be concave towards the anode. So, in the root, a weak current can induce a weak diffusion of the external water into the cells on the anode side. This theory does not, however, meet the conditions ; for, first, a long-continued weak current does not induce the positive curvature, and, secondly, because the decapitated root does not turn from the anode, and the irritation of the tip alone can induce the result. The mechanical theory must be rejected.

There remains only the other theory, that the negative tropism is a response to a stimulus of some sort applied at the tip. 
It is possible that the stimulus is due to a chemical agent produced by the current, or directly to the eurrent itself. The first alternative is opposed by the fact that the reflected Heitz waves, which have little or no gross chemical effect, still incite a response. There is every reason for concluding that the electric current, like gravity, and, as we shall see, light, acts in determining the direction of growth immediately.

The electric current appears to affect the rate of growth of some plants, so that they grow more rapidly when lying in the magnetic field or in a highly electrified atmosphere than otherwise; but this effect is often slight and uncertain. The directive effect on the growth of elongated organs is more marked. Apart from a false electrotropic effect produced by the injury of the positive side of the root, so that growth ceases on that side, there is a true electrotropic effect, which shows itself in a turning of the root from the anode. This is a true response to stimulus, depending for its consummation upon the presence of the root tip. The Hertz waves produce this effect in Phycomyces. Magnetism has an uncertain effect. The whole phenomenon is closely like that of response to gravity and light.

\section{LITERATURE}

Alor, A. '91. Dell' inflnenza dell' elettricità atmosferica. Malpighia. V, $116-125$.

'95. Dell' influenza dell' elettricità atmosferica sulla regetazione delle piante. Bull. Soc. Bot. Italiana. Oct. 1895 . pp. 188-195.

Berthelon de St. Lazare 1783. De l'électricité des végétanx, ouvrage dans lequel on traite de l'électricité de l'atmosphère sur les plantes, etc. Paris et Lyon: Didot. 468 pp. 3 Tab.

Brunchorst, J. '84. Die Funktion der' Spitze bei den Richtungsbewegungen der Wurzeln. II. Galvanotropismus. Ber. D. Bot. Ges. II, 204-219.

'89. Notizen über den Galvanotropismus. Bergens Mus. Aarsberetning for 1888 . No. $5.35 \mathrm{pp}$.

Ceni '78. Appareil pour expérimenter l'action de l'électricité sur les plantes vivantes. Comp. Rend. LXXXVII, 611-612. 22 Oct. 1878.

Chodat, R. '92. Quelques effets de l'électricité statique sur la végétation. Arch. Physiq. et Nat. (3), XXVIII, 478-481.

DuBors-Reymond, E.. '60. Ueber den secundären Widerstand, ein durch den Strom bewirktes Widerstandsphänomen an feuchten porösen Körpern. Monatsber. Berlin Ak. 1860. pp. 846-906. 
ELfving, F. '82. Ueber eine Wirkung des galvanischen Stroms auf wächsende Keimlinge. Bot. Ztg. XL, 257-264, 273-278. Apr. 1882.

Freda, P. '88. Sulla influenza del flusso elettrico nello sviluppo dei vegetali aclorofillici. Le stazioni sperimentali agrarie ital. Roma. XIV, 3956. [Abstr. in Just's Jahresber. XVI, 93, 94.]

Gautier, A. '95. [Comments on paper of Flaminarion.] Comp. Rend. CXXI, 960, 961. 16 Dec. 1895.

Grandeau, L. '79. De l'influence de l'électricité atmosphérique sur la nutrition des végétaux. Aun. de Chim. et de Physiq. (5), XVI, 145226. Feb. 1879.

Hegler, R. '92. Ueber den Einfluss des mechanischen Zugs auf das Wachsthum der Pflanze. Beiträge zur Biologie der Pflanzen. Band VI. Heft. III, 383-432. Taf. XII-XV.

Leмsтröм, S. '90. Om elektricitetens inflytande på växterna. Helsingfors, 1890. 67 pp. $4^{\circ}$. [Abstr. in Barley. Trans. Mass. Horticult. Soc. for 1894. 54-79.]

Lombardni '68. Forme Organiche Irregolari negli Ucelli e ne' Batrachida. Pisa, 1868.

Maggiorini, C. '84. Influenza del magnetismo sulla embriogenesi e sterilimento degli uovi. Atti Acad. Lincei. (3), Transunti, VIII, 274-279.

McLeod, H. M. '93. The Effect of Current Electricity upon Plant Growth. Trans. and Proc. New Zealand Inst. XXV, 479-482. May, 1893.

'94. The same. Ibid. XXVI, $463,464$.

Müller-Hetrturngen, J. '83. Ueber galvanische Erscheinungen an keimenden Samen. Arch.f. d. ges. Physiol. XXXI, 193-214. 2 MIay, 1883.

Riscriawi, L. '85. Zur Frage über den sogenannten Galvanotropismus. Bot. Centralb. XXII, 121-126.

Rusconi, MI. '40. Ueber künstliche Befruchtungen von Fische und über einige neue Versuche in Betreff küustlicher Befruchtung an Fröschen. Arch. f. Anat. Physiol. und wiss. Medicin (Müller). 1840. 185-193.

Thouvenrs, M. '96. De l'influence des courants électrique continues sur la décomposition de l'acide carbonique chez les végétaux aquatique. Rev. Gén. de Bot. VIII, 433-450.

Tolomer, G. '93. Azione del magnetismo sulla germinazione. Malpighia. VII, 470-482. [Abst. Just's Jahresber. XXI, 37.]

Warren, H. N. '89. The Effects of Voltaic Electricity toward Germination. Chem. News. LIX, 174.

Wrndee, B. C. A. '93. On Certain Early Transformations of the Embryo. Jour. of Anat. and Physiol. XXVII, 436-453. July, 1893.

'95. On the Effects of Electricity and Magnetism on Development. Jour. of Anat. and Physiol. XXIX, 346-351. April, 1895.

Wollny, E. '93. Electrische Culturversuche. Forsch. Agr. XVI, 243267. [Abstr. in Just's Jahresber. XXI, 36.] 


\section{CHAPTER XVII}

\section{EFFECT OF LIGHT UPON GROWTH}

We have seen in Chapter VII that light profoundly affects metabolism, not only by its heat rays, which are essential to the process of starch formation in green plants, but also by its more chemically active rays, which produce chemical changes in organisms of all classes. We have now to see how, as a result of these effects, light has an influence upon growth.

\section{$\S 1$. Ehfect of Light on the Rate of Growth}

Two fundamental principles, established in the First Part of this work, must be recognized at the outset of this discussion, or else the data which have been accumulated will appear confused and meaningless. The first principle is that white light is not a constant, definitely determined thing, but varies in its intensity, and, as we saw in the case of phototaxis (I, p. 201), at the different intensities produces diverse, even opposing, effects. The second principle is that not all organisms are similarly affected by the same intensity of white light. This is because they are attuned to diverse intensities of light, so that the same intensity will call forth a dissimilar response in different organisms ( $I$, p. 196). It is a consequence of these two principles that, when we classify our data on the basis of the intensity of the light, we shall find dissimilar effects in each class ; or when, on the other hand, we classify on the basis of results, we shall have to consider in each class apparently diverse causes. Since, however, results are always more certain than causes, we adopt the method of treatment on the basis of results.

1. Retarding Effect of Light. - We have already in the First Part of this work seen that Protista are injuriously affected by strong sunlight, cultures of bacteria becoming 
sterilized and ordinary aquaria being quickly deprived of living occupants. To the higher organisms, on the other hand, sunlight is generally not fatal, but is usually unfavorable to growth. This result is most clearly seen in seedlings. Thus Wiesser (79, p. 181) exposed seedlings of the vetch Vicia sativa under a clear glass globe to sunlight, after having marked off a centimeter's distance upon its zone of strongest growth, and having placed it in a horizontal position so that it should get the full force of the sun's rays. No growth occurred during seven and a half hours, although the control, in a darkened globe, turned its tip upwards and grew from 2.5 to $3.1 \mathrm{~mm}$. during that period. A vertical seedling of the same age was so protected by its foliage that in the sunlight it grew from 0.5 to $1.2 \mathrm{~mm}$. on the different sides. Thus, when the growing part of a seedling is exposed to sunlight, little or no growth occurs, and accordingly we find, as SACHs ('63) first pointed out, that the growing tissue of vegetative points is usually protected from the sun's rays.

In animals, likewise, it is noteworthy that embryonic tissue, and incleed the entire embryonic individual, is usually sheltered from sunlight. In animals the embryo is sheltered in the darkness of the maternal body ; in birds and reptiles the egg shells are not merely mechanically resistant, but more or less opaque, and, moreover, the whole egg is usually hidden from light.* The delicate, often externally pigmented, embryos of Amphibia are often buried by one of the parents or else develop among weeds in the water. More rarely, as sometimes in the case of frogs, they occur in open ponds, but then imbedded in a thick envelope of albumen. Fishes usually bury their eggs $\dagger$ or affix them to the under side of stones or place them in other shady retreats. To the general rule, however, pelagic fish eggs seem to constitute an important exception; but some of these, perhaps all, can change their level in the water (Hexsen and Apstern, '97, p. 63). Among molluses, embryos are often retained in the shell of the parent or laid in capsules and then

* Blaxc ('92) has indeed shown that the development of the hen's egg is much retarded when subjected in the incubator to daylight.

$\dagger$ Millet ('35) has shown that exclusion of light is the chief advantage gained in this habit. 
attached to the under side of rocks, hidden in sand or secreted in other shady places. Insects affix their eggs to the under side of leaves, provide nests for them, bury them in the earth, in masses of food, in a hundred places hidden from direct sunlight. Even the larvæ, which swarm on the surface of seas and

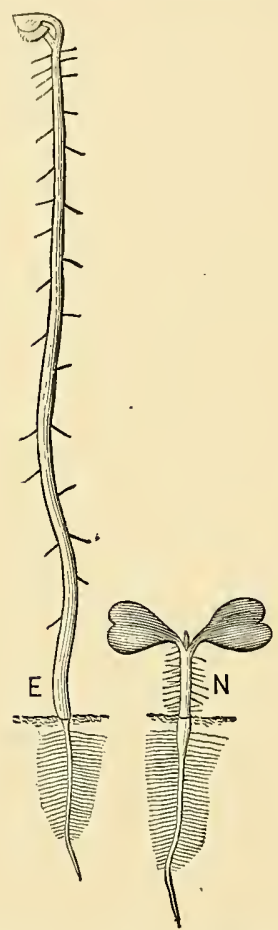

Fig. 118. - Two seedlings of Sinapis alba of equal age. $E$, reared in the dark, etiolated. $\mathrm{N}$, reared in ordinary daylight, normal. Root hairs arising from the roots. (From STRasBURGER, Noll, SCHENCK, and Schimper, Textbook of Botany.) lakes, sink before the rising sun and find protection beneath the superincumbent strata of water.* From these facts we may conclude that, in general, growth does not take place in nature in full exposure to sunlight.

Diffuse daylight, even the light which is essential to all healthy green plants, markedly affects their growth. This is a matter of every-day observation. Who has not observed the contrast between the elongated, scraggy form of plants grown in the dark and the repressed, compact form characteristic of the light? (Fig. 118.) Experiments and comparative measurements give us an insight into the degree of this difference. Take, for example, the case of tubers. Sachs ('63) planted similar potato tubers in flower-pots. One pot was covered with a clear belljar and placed in the window; the other, which served as a control, was covered by a large flower-pot, thus remaining in the dark. Both pots were kept equally moist. At the end of a period of 53 days, while the control tubers had produced sprouts from 150 to $200 \mathrm{~mm}$. ligh, those which had been

* The degree of protection from light afforded by layers of water is indicated by certain calculations of WHipple ('96), who finds that in a reservoir whose color is slight (0.33, platinum standard), a layer of water one foot thick absorbs $25 \%$ of the light falling upon it, so that only $0.75^{2}$, or $56 \%$, of the light at the surface gets below two feet; $0.75^{3}$, or $42 \%$, below three feet, and so on. 
exposed to the spring sunlight were only 10 to $13 \mathrm{~mm}$. high - a reduction to one-fifteenth the height in the dark. Many seedlings show the same thing; thus SAcHs found that the hypocotyl of the buckwheat (Fagopyrum), which attains a height of 35 to $40 \mathrm{~cm}$. in the dark, reaches only 2 to $3 \mathrm{~cm}$. when freely exposed on a sumny day - here again a reduction in height of about $94 \%$. This diminution in length is accompanied for a while by a climinution in size of the plant as a whole. This is shown by the measurements of KARsten ('71), who raised kidney beans in the dark and in the light for a month or two, and found that the entire individual reared during this period in the light weighed less than that reared in the dark.

The proportionate weight in dark and light was as 12 to 10 , fresh weight. The only organs which were heavier in the seedlings grown in the light were the roots (slightly) and the leaves (as 5.4 to 1 ). This excess in the growth of illuminated leaves as compared with those developed in the dark is characteristic only of such as have broadly expanded blades. Such leaves seem to require the light for their full development; they constitute a special case, the peculiarities of whose development will be considered together with that of other special cases in the last Part of this work. The growth of leaves, like that of the rest of the plant, is relatively retarded in the daytime, but this is probably due to the increased transpiration of that period (Prante, '73).

The effect of daylight upon the growth of stems is, as SACHS has pointed out, unequal in the different plants. In extreme cases (internodes of Bryonia, a wild gourd; of Dioscorea, the yam; etc.) daylight has no evident effect, for the stems have the scrawny, "etiolated" habit characteristic of plants grown in the dark. Plants which are little repressed by light are said by SAchs to be chiefly those whose rapidly growing parts are sheltered from the sun's rays by protecting coverings. We may conclude that the growth processes of such plants are little interfered with by strong light, because their protoplasm has through long experience become attuned to it. Except where such attunement has occurred, light tends to retard the growth of phanerogams.

The germination of seeds and spores of fungi is accompanied by processes akin to those of growth, and so may be treated here. The germinating protoplasm of seeds is partly shielded from light by a thick coat; nevertheless a series of careful 
observers in the early half of the century, and, more recently, Nobbe ('82), Adrianowsky ('83), and others, have shown that germination of seeds takes place slightly earlier in the dark than in daylight. Among fungi, also, we have the assurances of Hofmunv (' 60, p. 321) that the spores of the mushroom Agaricus campestris germinate more slowly in the light; and of DE BARY ('63, p. 40) that the spores of the potato fungus, Peronospora infestans, and its allies do germinate with difficulty in the daylight, and not at all in the sunlight. Thus

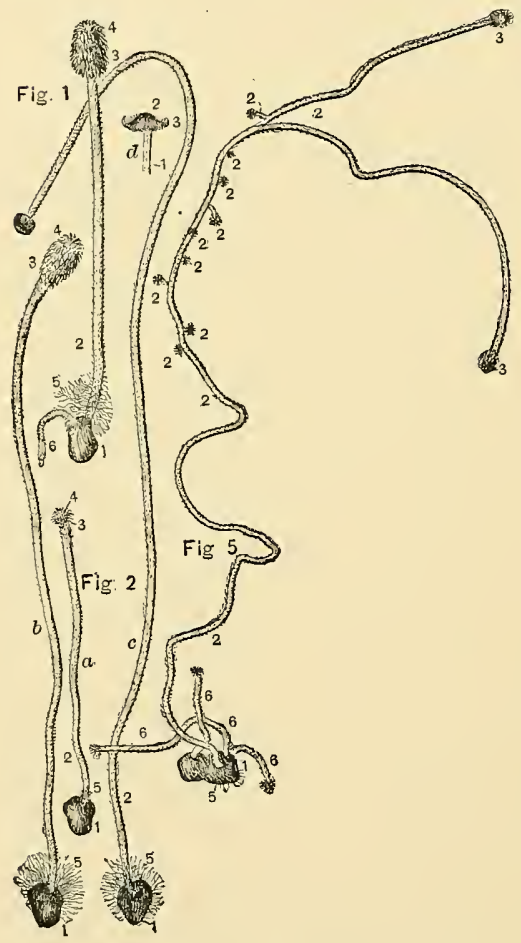

Frg. 119. - Coprinus stercorarius in reduced size. Fig. 1, typical young fruiting fungus reared in the light. Fig. 2, $a, b$, $c, d$, fungus reared in weak illumination. Fig. 5, Coprinus reared in darkness. 1 , sclerotium ; 2, 6, stalk ; 3, 4, fruit; 5, roots; 6, hyphæ. (From Brefeld, '77.) the germination of spores even more than of seeds is retarded by light (p. 174).

Passing now to the growth of fungi, we find numerous and harmonious observations on the effect of light. Fries ('21, p. 502) first noticed that the growth of fungi is retarded in the light, and Schmitz('43, p.512), Kraus ('76, p.6), Vixes ('78), STAMERoFF ('97), and other's have confirmed this result for hymenomycetes, the ergot fungus, and molds. * Brefeld ('77, p. 90 ; '89, p. 275) found that the toadstool Coprinus stercorarius reared in the dark attains a length of two feet or more, while in the daylight it is only an inch long (Fig. 119). Again, the sporangiferous hypha of the dung mold Pilobolus microsporus, which is eight or ten inches long in the dark, grows only half

* But Bullot ('97) denies it in the case of Phycomyces nitens. His experiments are not, however, convincing. 
an inch long in the daylight. Bacillus ramosus, in one case, grew during five hours, in the dark, $540 \mu$; in the light, $200 \mu$ (WARD, '95). These results demonstrate that the inhibiting or retarding effect of sunlight, and even of diffuse daylight, is probably uncomnected with the chlorophyll function, but is due to a more general effect of light upon growing protoplasm.

Even brief illumination has its marked effect. Thus VINES ('78, p. 137), who has made exact measurements of the hourly growth of the sporangiferous hyphre of the mold Phycomyces nitens, found that growth was diminished whenever the plant was subjected for only an hour to sunlight (Fig. 120). The same is true for phanerogams (GoDLEWSKI, '93).

'The great diurnal period of darkness and illumination to which plants are subjected in nature likewise has its effect on growth. The first studies made upon this subject were by Trew in 1727 . Numerous observers followed, but it was left to SACHS ('72), by the aid of his auxanometer, to obtain a

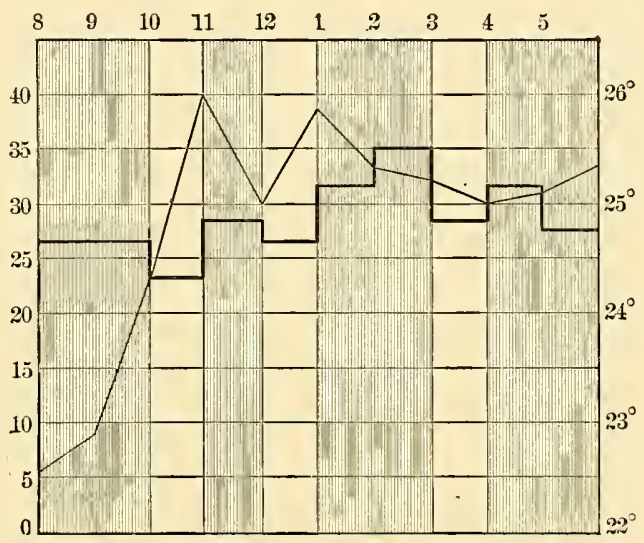

FIG. 120.-Diagram illustrating the retarding influence of light upon the growth of a sub-aërial hypha of Phycomyces. The thick line represents the course of growth, the thin line that of temperatures; the unshaded spaces, periods of exposure to light; the shaded spaces, periods of darkness. The figures at the left indicate tenths of millimeters, those at the right, degrees of temperature; those at the top, hours. (After VINEs, '78.) continuous curve of growth. This showed at a glance that during the night the rate of growth gradually increases, reaches a maximum at about daybreak, diminishes to a minimum a little before sunset, and then begins to rise again.* This variation in the rate of growth is opposed to the diurnal fluctuation of temperature, since this is low at night and high during the day. It is favored, on the other hand, by the circumstance that heat

* A similar periodicity has been detected among toadstools and puffballs by Kraus ('83, p. 97). 
and light favor transpiration; and this means loss of water and, consequently, of growth. Just how far these opposing effects neutralize each other cannot be said, but our comparative study gives assurance that the effect may well be produced by light acting alone. While the diurnal periodicity in growth can clearly be ascribed to no otler cause than the alternation of day and night, it is an important fact that this periodicity may be exhibited for several days after the plant has been placed in a room kept constantly dark. There is apparently a persistence of an effect impressed by environment.

Among animals the evidence of a retarding effect upon growth is not so clear. Maupas ('87, p. 1008), indeed, concludes from actual experiment that various ciliate Infusoria multiply with equal rapidity in the presence or the absence of light. In.the higher vertebrates, on the other hand, light, acting through the retina, increases destructive metabolism, as Moleschotт (55) first pointed out, so that many vertebrates undergo a greater loss of weight in the light than in the dark. Indeed, a diurnal periodicity in the weight of animals was described as long ago as 1852 , by BIDDER and ScHuIdT, who found that starving cats lost weight much faster in the day than at night. These facts constitute a not unimportant parallel with the conditions in plant growth.

In summarizing the foregoing facts on the retardation of growth by light, we see that strong sunlight usually completely inhibits growth, so that the growing parts of organisms, or entire organisms during the period of growth, are usually concealed. Even diffuse light retards growth, especially in the following organisms: most seedlings, many of the higher aërial fungi, germinating seeds in general, and spores of fungi. Also, light hastens destructive metabolism in the higher vertebrates so as to diminish weight rapidly. The organisms thus brought together are without exception aërial. This fact suggests that in plants, at least, the restraint of growth by light may be due to the rapid loss of water which accompanies illumination. The illumination of seedlings and fungi for only a brief period - an hour or so-retards their growth. These organisms likewise exhibit a diurnal periodicity in growth corresponding to the alternation of day and 
night. Not all seedlings and fungi are equally affected by light; the effect depends upon their normal conditions of illumination - the conditions to which they have become attuned.

2. Accelerating Effect of Light. - Although certain species of phanerogams are little affected in their growth by light, actual acceleration probably rarely occurs in this group. The parasitic mistletoe (Viscum album) seems to form an important exception, however, since, according to WIESNER ('79, p. 183 ; '98, p. 506), it neither grows nor germinates in the dark. This fact is correlated with a peculiarity in its-phototropic response, as we shall see later (p. 438). Among aquatic algæ several cases of acceleration of growth by light have been

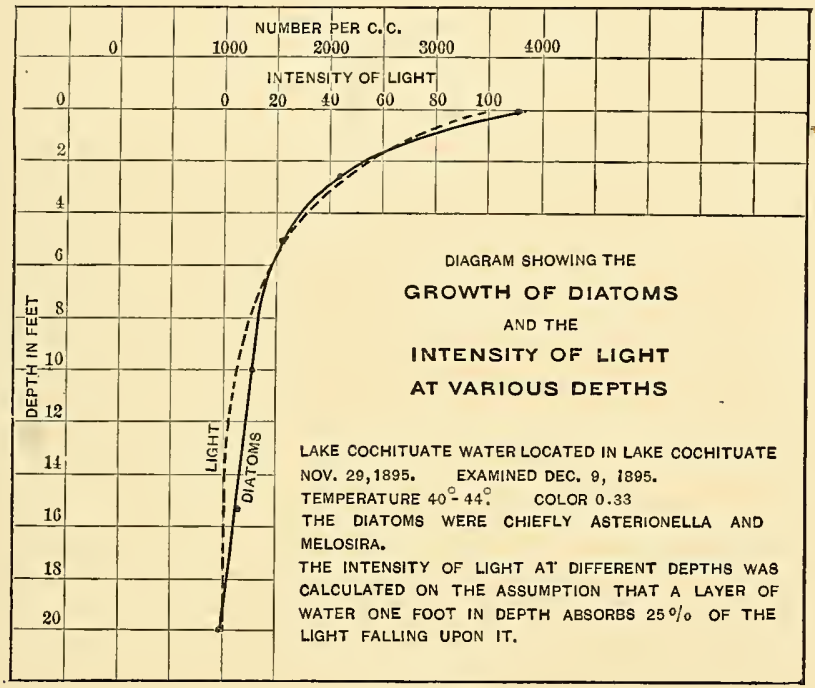

FIG. 121.

recorded. The flat, circular, green thallus of Coleochæte scutata, when obliquely illuminated, grows, according to Kry ('84), faster on the side next to the light. Again, Spirogyra which has been kept in the dark until all of its starch has been consumed grows when placed in the light, but does not grow in darkness (FAmixtzin, '67). Lately Whipple ('96) has given quantitative data on the relation between intensity of light and of growth in diatoms. A known quantity of diatoms of one or two species was placed in a bottle of water, 
covered with bolting cloth, and suspended in the water of a reservoir, at the surface and at various depths below the surface down to 20 feet. Experiments were made at a time when the temperature of the reservoir water was almost the same at all depths. After several days the bottles were collected and the number of diatoms in each determined. The results of one series of experiments, shown graphically in Fig. 121 , demonstrated that the growth of diatoms is directly proportional to the intensity of light received by them.* We may conclude that in general, excepting perhaps the mistletoe, those plants whose growth is accelerated by light normally have their growing parts fully exposed to sunlight. Their protoplasm is attuned to a high intensity of light-is not retarded by it ; indeed, demands it for the normal exercise of its functions.

Passing now to the subject of germination, we find that the first development of the spores of the higher cryptogams usually requires or is favored by light (Hofruans, '60, p. 321, and others). The spores of many ferns, of the moss Polytrichum commune (Borodis, '68), of the hepatics Duvalia and Preissia (Leitgeb, '77), and of Vaucheria do not germinate at all in the dark. However, this result is not universal among the higher green cryptogams, for MrLde ('52, p. 627) observed that spores of Equisetum germinated in the dark as well as in the light; and it is clear that certain fern spores (Ophioglossum) can do so, for they germinate when covered by soil to a depth of 3 to $5 \mathrm{~cm}$. It is somewhat unexpected to find the spores of such dark-lovers as ferus and hepatics normally dependent for their germination upon light. One calls to mind, however, the fact that it is the habit of such spores to germinate on the surface, where their prothalli are foundhence at such times always subjected at least to a diffuse light.

Certain seeds, also, are said to germinate more readily in the light than in the dark. We have already eited the case of the mistletoe; the same seems to be true of the meadow grass, Poa, as is shown by the following experiments of STEBLER ('81). Two species were experimented with, and two experi-

* However, Whipple found that growth at the surface, where full sunlight fell upon the bottle, was less than at a few inches below the surface. 
ments were made upon each species. In each experiment two lots of seeds were placed together in a thermostat; the one being subjected to daylight, the other being kept in darkness. The percentage of germination in the eight lots was as follows :-

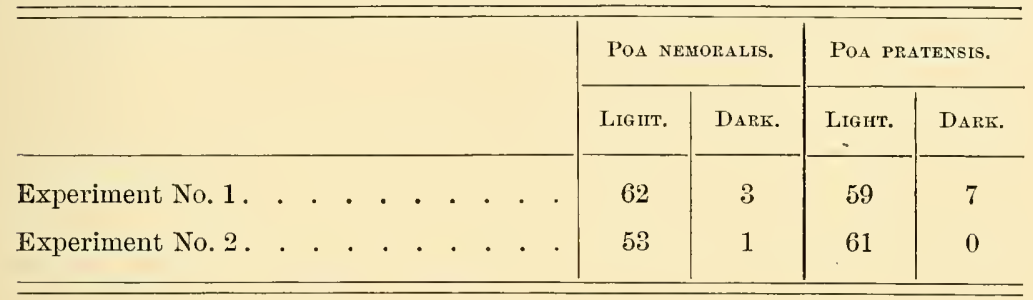

The result seems decisive and has been fully confirmed by Liebenberg ('84) and Jönsson ('93), not only for Poa but certain other small seeds.

According to Liebenberg the favorable action of daylight is due rather to the alternation of high and low temperature on the seed. Thus, while about $3 \%$ of Poa seeds germinate in a dark chamber kept constantly either at $20^{\circ}$ or $28^{\circ}$ C., $91 \%$ are germinated after 34 days in a dark chamber kept for 19 hours at $20^{\circ} \mathrm{C}$. and for 5 hours at $28^{\circ} \mathrm{C}$. In this case we have to do clearly with a response to a particular stimulus of the heat rays reminding us of the stimulus of alternating heat and cold necessary for the germination of certain animal statoblasts or gemmules (BraEır, '95).

Among growing animals, studies on the effect of light were early made by EDWARDs ('21), who concluded that tadpoles would not develop at all in the dark. In this he went as far from the truth in one direction as Higgenbotrom (' 50 and '63) and MACDONNeld ('59), who denied any difference of growth in the light and in the dark, did in the other. The work of YUNG ('78) first revealed the exact truth of the matter. This naturalist placed freshly laid frogs' eggs in vessels, each containing 4 liters of water and 60 eggs. One lot was placed in front of a window, where, however, it never received the direct rays of the sun. The other lot was kept constantly in the dark. Otherwise the conditions of the 
two lots were very similar. After 30 days, and again after 60, 3 typical tadpoles of each lot were measured. Their averages, together with those from a second series, are given below :-

\section{TABLE XLI}

Showing for Two Lots of Tadpoles the Relative Sizes attained in the Light and in The Dark

\begin{tabular}{l}
\hline \\
\hline
\end{tabular}

This table clearly shows that tadpoles grow faster in the light than in the dark, and that the difference in the rate of growth is more marked during the first than during the second month of development.*

Other animals have been experimented upon by YusG. He placed recently fecundated eggs of the sea trout, Salmo trutta, in 4-liter vessels, each of which contained 200 eggs. Those lots which were reared in the light hatched a day earlier than those reared in the dark. Also, the pond snails, Lymnæa stagnalis, reared in the light hatched in 27 days, whereas those reared in the dark required 33 days. Perhaps less weight is to be given to the observation of HAMmOND (73), who found that 20-day-old cats, reared under similar conditions except as concerns daylight, grew faster in the light than in the dark.

* With these experiments agree certain experiments of Lessova ('77) and Camerano (93) upon the size of tadpoles taken from ponds so thickly covered with vegetation as to shut out the light, as compared with tadpoles from fully exposed ponds. Camerano finds that, at the same stage of development, the sizes are as 9 to 14 , or the tadpoles reared in the light are $156 \%$ of the size of those reared in the darker ponds. Such observations in which the other conditions are not controlled are not, however, altogether satisfactory. 
There is thus a considerable body of evidence that a not too intense light accelerates the growth of animals in general.

To sum up, we find that diffuse light accelerates growth in the following organisms: Mistletoe seedlings, Coleochæta, etiolated Spirogyra, diatoms, germinating spores of many ferns, mosses, hepatics, and Vaucheria, germinating seeds of Viscum and small-seeded grasses, tadpoles, embryo snails, trout, and, perhaps, young kittens; in brief, of a parasitic seedling, of algæ, of germinating spores in many higher cryptogams, of a few germinating seeds, and of some animals. The collection seems like a heterogeneous one; yet omitting germination phenomena, the case of the parasitic mistletoe, and the doubtful cat, all the organisms concerned are aquatic. The reason why the growth of aquatic organisms is not restrained by light may be that with them light does not produce increased transpiration.

3. The Effective Rays. - As we have seen in the First Part the various rays of which white light is composed affect protoplasm diversely. The question now arises, What part do the separate kinds of rays play in the retarding and accelerating effect of light on growth - what are the rays upon which these effects especially depend?

At the outset it must be stated that a large part of the recorded observations upon this subject is worthless because the methods were not quantitative. Let us suppose we have a white light of known intensity which inhibits growth, and that we desire to kuow which of the component rays are most effective in imbibition. The different component rays should have the same intensity as they have in the given white light. For a more effective ray of weak intensity will produce a smaller result than a less effective ray of great intensity; becanse not only quality but intensity of the light determines its effect. Now, insufficient care has been taken to measure, by the methods given in Chapter VII, the intensity of the colored light employed; consequently it is little wonder that most contradictory statements are given as to the effect of red, green, and violet light upon related organisms, and that great caution is demanded in drawing conclusions from the data at hand.

\section{a. The Effective Rays in the Retardation of Growth by Light.} - We have already seen (p. 166) that experiments upon the effect of the different rays upon metabolism occupied the attention of naturalists in the first half of the century. It was but 
a step to the study of the effect of these rays upon growth, and this step was taken by SACHs in 1864 .

The method of subjecting the plant to particular rays was as follows: The apparatus consisted of a glass jar, placed inside of a larger glass jar, the interspace being filled with a colored fluid. This apparatus stood belind a sontheast window. Orange light was obtained by 12 to $13 \mathrm{~mm}$. of a saturated solution of potassium dichromate, which transmitted red, orange, and yellow, but no blue or violet; and blue light, by the same thickness of ammoniated copper sulphate, which excluded all rays of shorter vibration than the green, but, likewise, reduced the intensity of the violet end of the spectrum. The relative chemical intensity of the light passing through the solutions was determined by noting the time required to blacken photographic paper held in the inner jar.

Under the conditions of the experiment young seedlings of the white mustard, Brassica alba, and of flax, Linum usitatissimum, grew more rapidly and vigorously in the orange rays, which act thus like darkness, than in the blue, which act thus like daylight. In orange light the leaves, although differentiated, remain small, while the internodes are elongated; in both of which respects the plants show themselves etiolated. In the blue rays the cotyledons, unlike the leaves, remain small; since, in the absence of assimilation, which requires red rays, they are drawn upon for food. Throughout, the less intense blue rays acted more like white light than the more intense orange rays.

Several confirmatory experiments upon other plants may now be briefly considered. BERT ('78, p. 986) cultivated a Sensitive Plant in a lantern made of red glass. It lived for months, elongated considerably, and had small leaves; one might have called it etiolated but for its remaining green, owing to the formation of chlorophyll in the red rays (p. 170, note). Behind blue glass it had the general form characteristic of white light, but it did not grow as large as in claylight - which includes also the warmer rays. The whole habit of the plants in the red rays indicated greater turgescence than in the blue : a result which BerT suggests may be due to the manufacture in the presence of the red-yellow rays of a material (glucose) causing an endosmotic flow. This explanation, however, seems negatived by the fact that plants grown in darkness exhibit this same condition. WeIsNeR 
(93) finds that the stems of seedlings of Vicia faba grow behind SAcHs' blue solution, which reduces the intensity from one-third to one-half that of daylight, nearly as slowly as in daylight, and much more slowly than in darkness, in the ratio of : daylight, 141 ; blue, 155 ; darkness, 185 . Again, FuAlImarion ('95) cultivated the Sensitive Plant in little conservatories behind clear and colored glass.* From a lot of seedlings reared under normal conditions those were selected which were most alike (all $27 \mathrm{~mm}$. high), and placed, July 4th, in the various conservatories. On October $22 \mathrm{~d}$ the plants had the following average heights : in the red, $420 \mathrm{~mm}$. ; green, 152 mm.; white, $100 \mathrm{~mm}$. ; blue, $27 \mathrm{~mm}$. (Fig. 122). Thus, under

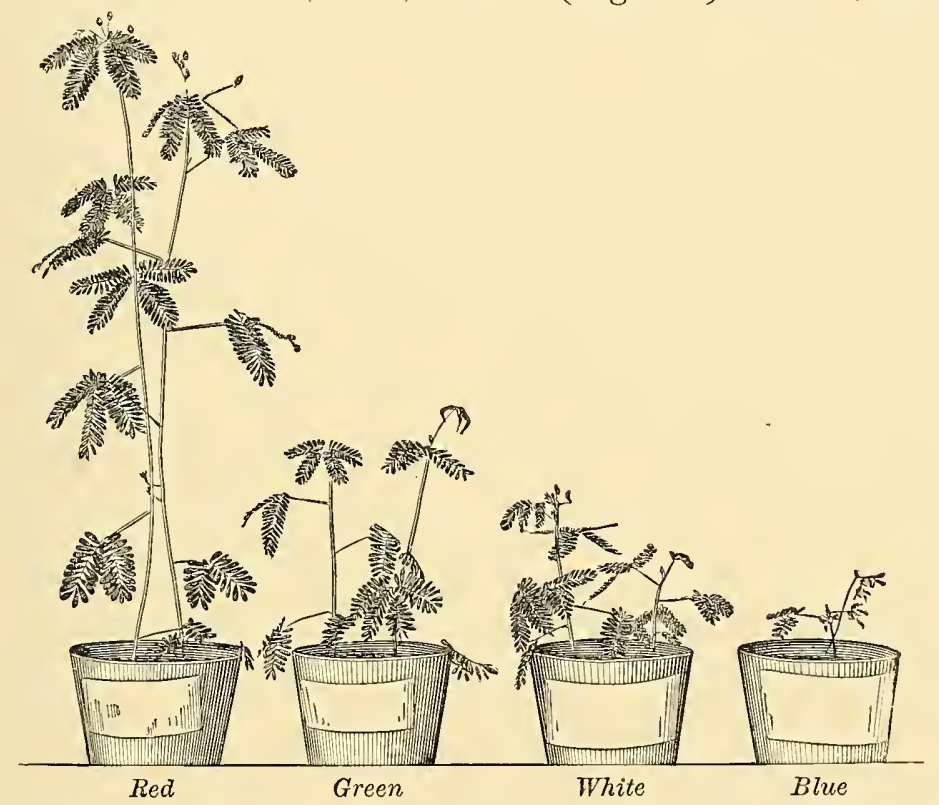

Fig. 122. - Action of different solar rays upon the growth of the Sensitive Plant. On August 1st, placed as seedlings each $27 \mathrm{~mm}$. high behind diversely colored glass screens. Photographed Oct. 22. (From Fuammarion, '95.)

* The data concerning methods are as follows: The blue glass used transmitted only the more highly refracting rays; the red was almost strictly monochromatic; the green was less satisfactory, but let through no red. The intensity of illumination decreased considerably in the order: white, red, green, blue. The conservatories were placed side by side, under similar conditions, and a current of air was passed through, from one to the other, to maintain a uniform temperature. 
red light, as in darkness, the greatest growth occurred; under the blue light no growth had occurred, i.e. less than under the clear glass. The order of height was thus : blue, white, green, red ; that of the vigor of vegetation was : blue, green, white, red. The peculiarly injurious effect of the violet and ultra-violet rays is shown also in the deleterious action of electric light, which is rich in these rays (SIEmens, '80, '80', '82). All the foregoing observations are thus in accord, and indicate that the retarding action of white light upon seedlings is the resultant of the accelerating and the inhibiting actions of the different rays.

Among fungi we have observations by Vines (78) which show that Phycomyces nitens, subjected intermittently to the action of darkness on the one hand, and of white light, blue light, or yellow light, on the other, suffered a similar retardation in white and blue light, while in yellow light no marked retardation occurred.* Bacillus ramosus (Fig. 123) grows behind a red screen as in darkness; behind a blue screen (of $\mathrm{CuSO}_{4}$ ) its growth is retarded as in daylight (WARD, '95, p. 381).

Among algæ FAmintzin ('67) has found that Spirogyra which has been kept in the dark until all of the starch is consumed grows more rapidly in the successive members of this series: darkness (no growth), blue light, full lamplight, yellow light. Here we see that, while a certain amount of light is necessary to the metabolism of the etiolated alga, growth, as a whole, is favored by the absence of blue rays.

Animals which are symbiotic with algæe flourish or decline with the latter. Accordingly, YUNG ('92) has found that Hydra viridis, $\uparrow$ which has this kind of symbiosis, grows more rapidly in the successive members of the series: darkness (fatal), violet, green, white, and red. This series is essentially that just given for algæ living alone.

* Kraus ('76) says that Claviceps growing in daylight attains a length of only 4 to $6 \mathrm{~mm}$.; in green rays, $17 \mathrm{~mm}$.; in yellow and blue, each, $30 \mathrm{~mm}$. ; and, in the dark, $36 \mathrm{~mm}$. Not much weight can be given to this statement, since an account of methods is lacking.

$\dagger$ A similar result was obtained with the green turbellarian Convoluta Schultzii. 
The foregoing concordant observations may be summed up in the statements that the action of white light upon seedlings is the resultant of the action of the component rays; that, of these, the red tends to favor growth by rendering possible starch formation; the blue, on the other hand, tends to

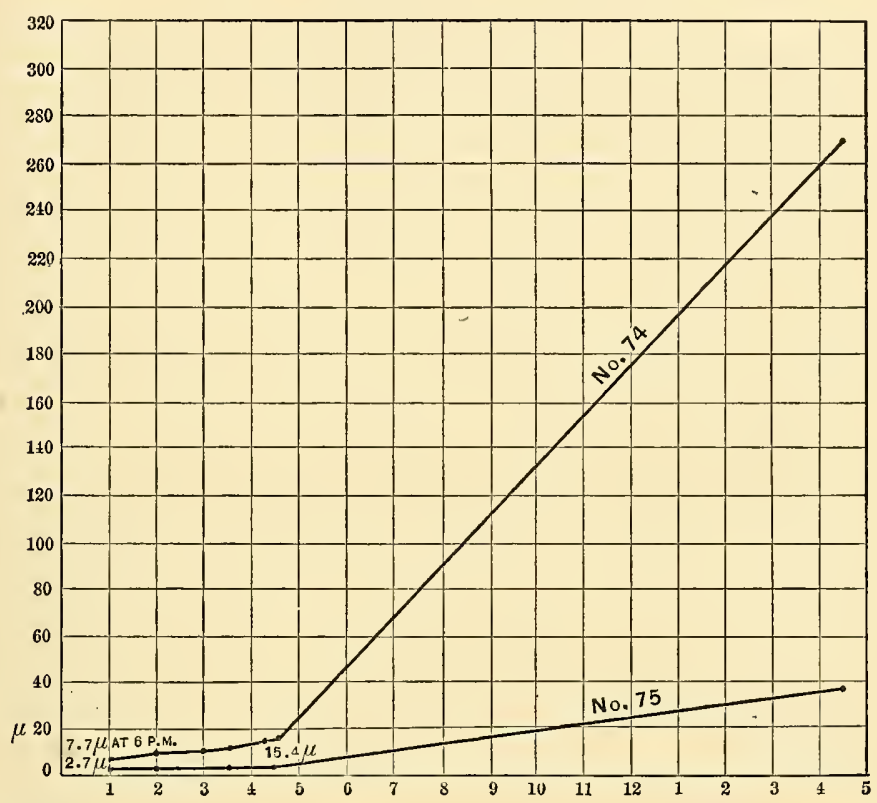

Fig. 123. - Curves of growth of threads of Bacillus ramosus in blue light (Experiment No. 75, of WARD) and in red light (Experiment No. 74). The numbers at the left indicate microns; at the bottom, hours. The retardation due to blue light is evident. (From WARD, '95.)

restrain growth, probably by introducing certain destructive (or controlling) chemical changes ; that, in the dark, seedlings being freed from the restraining action of the chemical rays, grow rapidly so long as the stored food products permit; that, in daylight, although the means of nutrition is provided, the presence of the inhibiting blue rays tends to cause slow growth. Upon other organisms whose growth is retarded by light, the effect of white and blue light must be quite the same; and the experiments of VINES and of WARD upon fungi show that this is the case. The effective rays in retardation of growth are clearly those at the blue end of the spectrum. 


\section{b. The Effective Rays in the Acceleration of Growth by} Light. - We have seen that the effective rays in retardation are the blue; the question now arises: Will the same rays serve, in other cases, for acceleration, or must the latter be due to the red rays?

As concerns the germination of ferns we have the observations of Borodin ('68, p. 435), in the case of Aspidium, that germination did not take place in the blue any more than it did in darkness, while the red rays produced nearly the whole effect of white light. Germination in this case seems to demand the red rays for its processes - processes consisting largely of certain chemical changes favoring imbibition of water. Probably those seeds which germinate more rapidly in the light than in the dark make similar use of the red rays, as Jönsson ('93) has, indeed, found they do in the case of Poa.

Passing now to animals, we find the first critical work on these organisms is that of BECLARD ('58). This experimenter placed at one and the same time, under diversely colored glass bells, eggs of the flesh-fly, Musca carnivora, taken from a single laying. All the eggs produced larve; of these, the largest were formed under the violet or blue glass, the smallest under the green. The effect of the other colors was intermediate and fell in the following order: violet, blue, red, yellow, white, green. The larvæ reared under the violet rays were three-fourths greater than those reared under the green.* The apparent acceleration in violet, as compared with white light, indicates that the green rays of white light retard. This was the result actually obtained by SchNetzLER (74, p. 251), who found that tadpoles developed more slowly behind green glass (from which red and violet rays chiefly were cut out) than behind clear glass.

YUNG (78) made more critical experiments upon tadpoles. Screens of nearly monochromatic solutions were used (p. 157). The size of the vessels and the number of tadpoles in each

* Exactly opposite results for blow-flies are given by Davidsox ('85), whose work, however, strikes one as crude. Fly larvæ reared in a bottle made of blue glass had at the end of nine days only half the weight, on the average, of larvæ reared either behind clear glass or in the dark. This subject needs careful investigation. 
were the same. At the end of one month ${ }^{*}$ three tadpoles were taken at random from each vessel and measured. In the following tables are given the average length and breadth of these tadpoles (from series of 1876 and 1877), and also the lengths compared with that in white light:-

\section{TABLE XLII}

Average Dinensions of Tadpoles reared behind Clear and Colored Screens during One Month

\begin{tabular}{l|c|c|c}
\hline Color of Light. & A derage Length. & Average Breadth. & $\begin{array}{c}\text { Length compared with } \\
\text { White Light. }\end{array}$ \\
\cline { 2 - 3 } White. . . . . & $24.43 \mathrm{~mm}$. & $5.37 \mathrm{~mm}$. & 100 \\
Violet. . . . & 28.58 & 6.75 & 117 \\
Blue . . . . & 25.66 & 5.70 & 105 \\
Yellow . . . . & 24.37 & 5.46 & 99 \\
Red . . . . . . & 20.37 & 4.66 & 83 \\
Green. . . . . & 16.99 & 3.91 & 70 \\
\hline
\end{tabular}

Similarly, averaging the dimensions of the tadpoles at the expiration of two months, we obtain :-

TABLE XLII $a$

Average Dimensioxs of Tadpoles reared behind Clear and Colored Screens durivg 'Two Months

\begin{tabular}{l|c|c|c}
\hline Color of Light. & A verage Lengti. & Average Breadth. & $\begin{array}{c}\text { Length compared with } \\
\text { W hite Light. }\end{array}$ \\
\cline { 2 - 3 } White. . . . . & $31.58 \mathrm{~mm}$. & $7.50 \mathrm{~mm}$. & 100 \\
Violet. . . . . & 42.32 & 10.41 & 134 \\
Blue . . . . & 33.92 & 8.00 & 107 \\
Yellow . . . . & 32.24 & 7.50 & 102 \\
Red. . . . . . & 27.17 & 6.50 & 86 \\
Green. . . . . & All & died before & two months \\
\hline
\end{tabular}

Tadpoles reared in the dark were uniformly slightly larger than those reared in red light, while violet and blue light show themselves especially favorable to the growth of the frog.

* During the first days of development in the cases of the frog, the snail Planorbis, and the sea-urchin Echinus, there is, according to Driesci ('91), no difference in the rate of growth behind various colored glasses. The diverse effects of different rays appear only in later stages. 
Upon Echinoderm larva Verixon ('95) has made some important experiments. He used YUNG's methods of getting colors; but relative intensity is not indicated. The following table gives his results :-

\section{TABLE XLIII}

Percentage Deviations in Length of Larye of Strongylocentrotus lividus reared behind Variods Colored Screexs, from Length of Larve reared in White Light

\begin{tabular}{|c|c|c|}
\hline Color. & $\begin{array}{l}\text { NUMBER OF SETS oF } \\
\text { EXPERIMENTS. }\end{array}$ & Mean Change. \\
\hline Semi-darkuess . . . . . . . & 3 & $+2.5 \%$ \\
\hline Complete darkness . . . . . . . & 4 & -1.3 \\
\hline Blue (copper sulphate) . . . . . & 2 & -4.5 \\
\hline 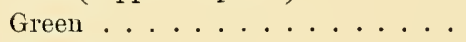 & 4 & -4.8 \\
\hline $\operatorname{Red} \ldots \ldots \ldots \ldots$ & 2 & -6.9 \\
\hline Blue (Lyon's blue) . . . . . . . & 2 & -7.4 \\
\hline Yellow . . . . . . . . . & 2 & -8.9 \\
\hline
\end{tabular}

All larva reared in violet light soon died on account of the development of bacteria. In this case the order of growth followed the series: white, blue (of copper sulphate solution), green, red, blue (of Lyon's blue), yellow. This series differs so much from BECLARD's that the experiment demands confirmation.

Certain experiments of YUNG on the relative time of hatching may be given here, since the time of hatching depends upon rate of growth :-

\section{TABLE XLIV}

Relative Time of Hatching of Organisms reared behind Colored Screens

\begin{tabular}{|c|c|c|c|}
\hline LOLIGO VULGARIS. & SALMO TRUTTA. & LTMNEA STAGNALIS. & Average \\
\hline 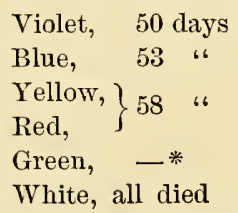 & $\begin{array}{l}\text { Violet, } 32 \text { days } \\
\text { Yellow, } 34 \text { "6 } \\
\text { Blue, } \\
\text { White, } \\
\text { Green, } 36 \text { " } 36\end{array}$ & $\begin{array}{l}\text { Violet, } 17 \text { days } \\
\text { Blue, } 19 \text { "6 } \\
\text { Yellow, } 25 \text { "6 } \\
\text { White, } 27 \text { "6 } \\
\text { Red, } 36 \text { "، } \\
\text { Green, all died }\end{array}$ & $\begin{array}{l}\text { Violet } \\
\text { Blue } \\
\text { Yellow } \\
\text { White } \\
\text { Red } \\
\text { Green }\end{array}$ \\
\hline
\end{tabular}

* Had not hatched by 62 days. 
These series run then in order of effect on growth exactly parallel to the series obtained from the growing tadpole, and are very similar to the series obtained by BECLARD for the blowfly.

There are certain a priori grounds for believing that BECLARD's series is the more correct, not only for growing flies, but for all animals. We would then get for a curve of relative effect of the different parts of the spectrum upon growth something like Fig. 126, I. * The conclusion to which all these experiments point is this : the accelerating effect of weak white light upon the growth of animals, contrary to the case in plants, is due to the short-waved rays.

The alleged peculiar effects of the green rays cannot go unnoticed. These seem to have been first insisted upon by BERT ('72, '78), who found that in the green lantern the young sensitive plant lost sensibility and died in three or four days, which is about the time in which they would have died in complete darkness. This observation has been confirmed by several experimenters ; for example, by Kraus ('76, p. 8), Adrianowsky ('83), Villon ('94, p. 461), and Gautier ('95) for plants, and by Schnetzler and by Yung for tadpoles. Yet, on the other hand, Flammarion ('95) found no peculiar action of green light upon the sensitive plant. In the absence of precision in the opposing statements, we may doubt whether green rays, as such, produce any positive harm. It is probable that they are neutral in growth.

Summing up the results of our study on the effective rays in the modification of growth by light, we find that retardation, as it occurs in most aërial plants, is due to the chemically active rays; that acceleration, as it occurs in animals, is likewise due to the same rays. Both effects must be due to chemical, metabolic changes, induced by light: in the first class,

* The favorable effect of violet or blue rays was noticed also by Villon ('94, p. 463) upon silkworms. Here may be mentioned the "blue glass" rage of twenty years ago, which was largely due to the writings of General A. J. Pleasonton ('76), which, while containing a basis of truth experimentally obtained by the author, were of a highly uncritical and even sensational character. 
these are of an injurious character; in the second, they favor the metabolic growth processes. Long-waved light, on the other hand, has usually no more effect than darkness, or the absence of light. However, upon germinating ferns and grasses long-waved light has a decided accelerating effect. Since even in daylight growth occurs faster than in the dark we must conclude that upon these organisms the blue rays do not seem to exert an injurious effect; they are, as it were, blind to the blue rays, and hence experience no freedom from restraint in the dark, and, unlike seedlings, no excessive growth there.

4. The Cause of the Effect of Light on the Rate of Growth. - The action of red rays upon growing phanerogams requires no special explanation here. It is clear, from what we already know, that an etiolated seedling, or alga, can develop only in the presence of the red rays, which are ordinarily essential to its nutrition. Consequently, we find that red rays do not hinder the growth of ordinary seedlings, but cause etiolated green plants as well as seedlings of ferms and grasses to grow faster than they would in the dark.

The action of the blue ray does, on the other hand, demand more detailed consideration, for it seems at first as if its diverse effects upon plants and animals constitute a great difficulty. Why should the same rays retard the growth of aërial organisms and accelerate that of vater animals? In inventing an hypothesis to fit the case, we have first to recognize that the action of the blue ray is a chemical one, and is probably of the same kind upon all organisms. It must, consequently, be that the degree of the effect is different. This difference may be due either to a difference in the quality of the different protoplasms or to a dissimilarity of the external conditions under which the effect is produced. We may say that, either on account of the presence of abundant free oxygen in the air, or, perhaps, on account of a greater lability of plant protoplasm, the blue rays effect such extensive transformations (oxidations, Quincke, '94) in aërial plants as to interfere with growth, possibly, by promoting loss of water. Upon water organisms, on the other hand, only slight metabolic changes occur, which, on the whole, favor the imbibitory or assimilative processes. 


\section{§ 2. EFFect of Light UPON the Direction of Growth - Рнототropisi *}

Under this topic will be considered, first, the effect upon plants ; secondly, upon animals; and, after that, certain general matters concerning phototropism.

1. Plants. - The fact that seedlings reared in a room near a window all have their tops directed towards the source of light instead of vertically can scarcely have escaped any one's notice. References to the phenomenon are found in the literature of the ancients; its scientific study was begun in the early part of the last century by HALES (1727). Not only the stems of seedlings but many other plant-organs show this growth with reference to the direction of the infalling rays of light. Among these are tips of many stems, many leaves, cotyledons, roots (especially aërial ones), tendrils, the fruit-bearing hyphre of cryptogams, and certain organs of the bryophytes and pteridophytes.

The sense of the turning in ordinary daylight is not always the same. While the stems of most seedlings of phanerogams turn towards the light (positive photo-

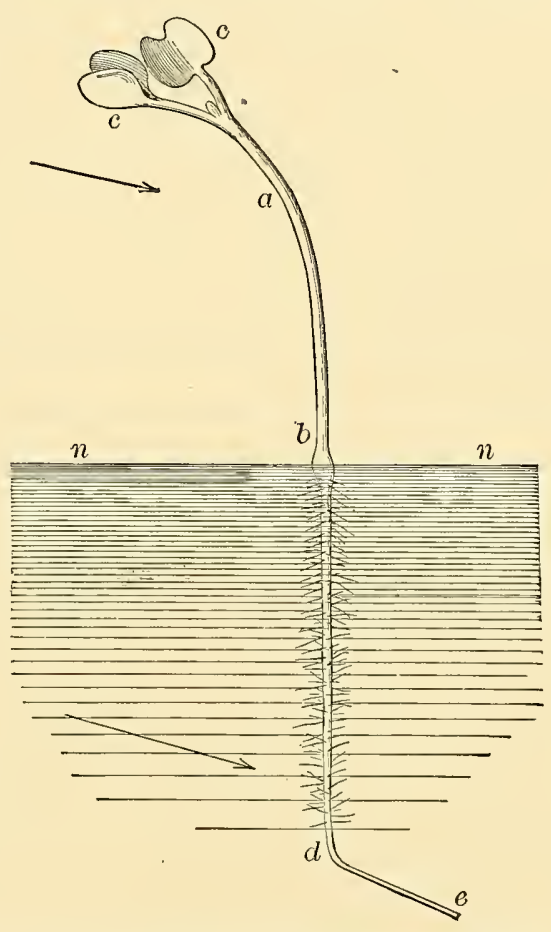

FIG. 124. - Seedling of Sinapis alba exhibiting positive phototropism of the stem, $a b$, and negative phototropism of the root, de. $n n$, surface of the water in which the plant is germinating. The arrow indicates the direction of the infalling light rays. (From Frank, '92.)

* On some accounts it is unfortunate to accept this word rather than the older, more familiar term "heliotropism "; but as the latter is obviously unfitted to our broader view of the subject, and encourages the introduction of new special terms, such as selenetropism or turning towards the moon (Musset, '90), I think it is desirable to adopt the newer term. 
tropism), the following turn from it (negative phototropism): the hypocotyl of the seedling mistletoe; the roots of many plants, e.g. Sinapis (Fig. 124), Helianthus, Vicia faba, Zea mais, etc.; stems of some recumbent dicotyledons, e.g. the moneywort; the root hairs of the prothalli of ferns and hepatics; the tendrils of the vines Vitis and Ampelopsis. As we shall see later, however, the sense of turning is, within limits, dependent upon the intensity of the light.

Finally, we observe that plants differ greatly in the degree of their phototropism. Thus aquatic plants and non-chlorophyllaceous phanerogams are only very slightly phototropic (compare Hochreutiner, '96).

The general phenomena of positive phototropism are seen when a seedling which has been growing in the dark is illuminated upon one side by a horizontal ray. The tip of the seedling, which is normally constantly "nutating" about the vertical line passing through its axis, now begins to move towards the light side of the vertical. The quickness with which it does so seems to vary with the species and with the intensity of illumination of the plant and other conditions of the environment; the turning may be evident in 15 minutes* or it may be delayed for several hours. There is apparently a certain, not precisely determined, latent period elapsing between illumination and response. The curvature first appears just behind the tip of the seedling, but later almost the whole

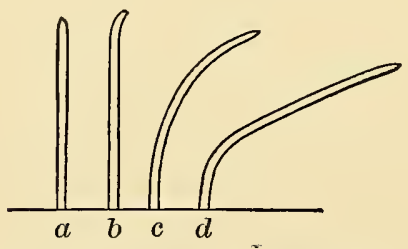

FIG. 125. - Course of phototropic curving of the cotyledon of Avena sativa. $a$, before illuminatiou; $b$, after $1 \frac{1}{2}$ hours ; $c$, after $3 \frac{1}{2}$ hours; $d$, after $7 \frac{1}{2}$ hours. (From Rothert, '94.) stem above the ground becomes involved, so that after several hours it points straight towards the source of light (Fig. 125).

The intensity of light necessary to provoke the maximum response varies with the species. WIESNER ('93) especially has made accurate determinations on this subject.

The unit of measurement is a normal candle (p. 160) burning at a distance

* Darwin ('81, Chapter IX) found with the aid of a microscope that the tip may begin to turn in from 3 to 10 minutes. 
of one meter from the organism (meter-candle). A flame of one candle power at a distance of five meters has, therefore, an effective intensity of $1 \div 5^{2}=0.04$ "meter-candles." An ordinary flame of gas, kept at constant pressure by means of a manometer, was employed in the earlier experiments; a "microburner" in the later ones.

The following table gives the optimum intensity in the case of various seedlings, in units of the meter-candle, at a temperature of $20^{\circ}$ to $27^{\circ} \mathrm{C}$. and at a humidity of 75 to $77 \%$ :-

\section{TABLE XLV}

The Optinum Intexsity for Phototropisal in Various Species of Plants.

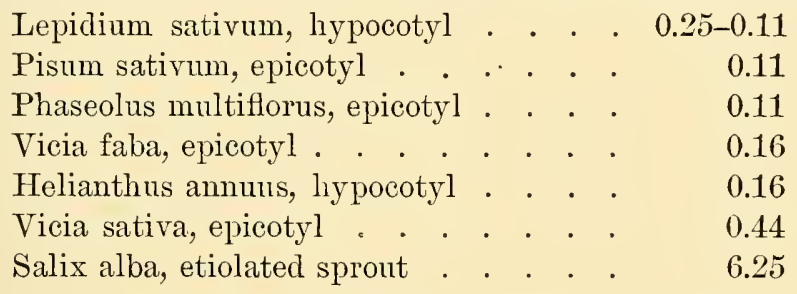

This table shows also the effect of preceding conditions of illumination; the etiolated plant has a very high optimum.

At an intensity of light above the optimum the phototropic response is less pronounced until, finally, at between 100 and 800 meter-candles it disappears. At an intensity below the optimum a similar diminution in response occurs; but the minimum lies often remarkably low. Thus Figdor ('93) has found the minimum to lie for the different species at or just below the following intensities (in meter-candles). The temperature was $15^{\circ}$ to $24^{\circ} \mathrm{C}$, and the humidity between 58 and $80 \%$.

\section{TABLE XLVI}

The Minimum Intensity for Phototropic Response in Variods Species of Plants

Lepidium sativum, Amaranthus melancholicus ruber, * Papaver pæoniflorum, and †Lunularia biennis . linit below 0.00033 *Vicia sativa . . . . . . . . . . . . . . . . . 0.0026 Salpiglossus sinuata, Reseda odorata, Iberis forestieri 0.004 to 0.16 Mirabilis jalappa, * Helianthus annuus, * Dianthus chinensis 0.016 * Xeranthemum annuum, *Raphanus sativus, * Helichrysum monstrosum, * Capsicum annuum, Cynoglossum officinale 
This list shows that different plants have diverse phototropic sensitiveness. Since in this list species preceded by an asterisk (*) live in the sunlight, that preceded by a dagger $(\dagger)$ is a shade-loving plant, while the others live in an intermediate habitat, we may conclude that, in general, sun-loving plants are less sensitive to light than those not markedly sun loving. The former exhibit a sort of acchimatization to light.*

The effective rays have been determined by WIEsser ('79, p. 191) for seedlings of several species as a result of experiments in which colored solutions were employed. His results are summarized in Fig. 126, which shows that the phototropic effect is greatest at the violet end of the spectrum, and that as we pass towards the $\mathrm{D}$ line, lying between the yellow and the orange, the effect diminishes, becoming null at $\mathrm{D}$. In the red, again, there is a considerable effect. Beyond the visible red,

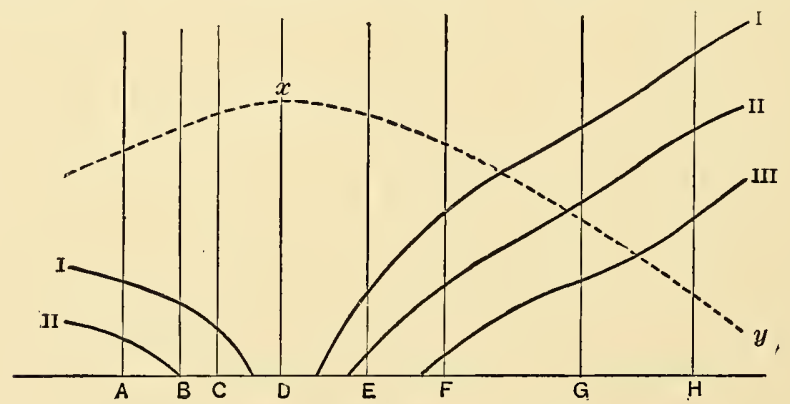

Fig. 126. $-A-H$, positions of Fradenhofer's lines in the spectrum.

- curves of phototropic effect of the various rays; the ordinates have only relative values. $I, I$, curve for the seedling of the vetch, Vicia; $I I, I I$, for cress seedlings; $I I I$, for etiolated willow shoots, upon which latter the more strongly refractive rays only act phototropically.

----, curve of retardation of growth in length of Helianthus seedlings reared in the various rays. The ordinates give the increment in length of the seedling subjected to the ray under consideration; thus the retardation is least at $x$, and is greatest at $y$. (From WiEsner, '81.)

* Certain plants are so sensitive to differences of illumination on their two sides as to make very delicate photometers. Thus Wiesner determined as nearly as possible by Buxsex's photometer the point of equal illumination between two flames, but a seedling still detected a difference between their intensities. Massart ('88) has made use of this method to demonstrate for phototropism the validity of Weber's law. He found that in Phycomyces a difference of intensity of $18 \%$ between two sources of light could be detected; and this held true for all intensities of light. 
in the region of the dark heat rays, we find an effect still produced. This effect of dark heat rays will be referred to again in the next chapter.

The Responding Region. - We have already seen that the curvature begins a short way below the tip of the stem of the seedling. Further study shows that this region of first curvature is also that of maximum growth. The response does not, however, end here, but passes basalwards even after the seedling is transferred to the dark. Also in roots, the region of maximum negative curvature is that of most rapid growth (MÜlLER, '76).

The Perceptive Region. - In most cases the region of response is also that of perception. But DARwin ('81) found that in some organs this is not the case. When, for example, the phototropic cotyledons of the seedlings of grasses and grains were deprived of their tips for a distance of 2.5 to 4 mm., they exhibited no phototropism; but when only 1.3 mm. of the tip was cut off, the curving occurred, although in diminished degree. Again, when the tips of some of the cotyledons were covered with opaque caps made of glass thickly painted with India ink, while others were covered with transparent glass, the first lot remained straight or nearly so, whereas the second curved normally. From such results DARwin concluded that the tip of the cotyledon is the chief perceptive region. That it is not the only perceptive part, even in cotyledons, follows from the observations of RoTHERT ('94), who finds that a slight curvature succeeds the illumination of the basal part alone of the cotyledon. In some seedlings of dicotyledons, indeed, the perceptive region exists nearly equally developed along the whole stem.

In those cases where the tip of the plant is alone perceptive there must be the transmission of an impulse from the perceptive to the bending region. The rate of this transmission is variable; in favorable cases it is about $2 \mathrm{~cm}$. per hour (Rothert, '94, p. 209). If we define "irritation" or "stimulation" as the condition of the protoplasm immediately antecedent to its response, — as the chemical transformation lying behind the visible result, - then, since in these plants the response occurs some distance from the perceptive region, we 
must conclude, with Rothent, that here, as in animals, stimulation is a process distinct from perception.

2. Animals. - Phototropism among animals will naturally be limited to elongated, sessile forms. It has hitherto been detected only among hydroids and worms of the family Serpulidæ.

a. Serpulidoe. - A type of response to light intermediate between phototaxis and phototropism is described by LOEP ('90) for Spirographis spallanzanii. This worm (Fig. 127)

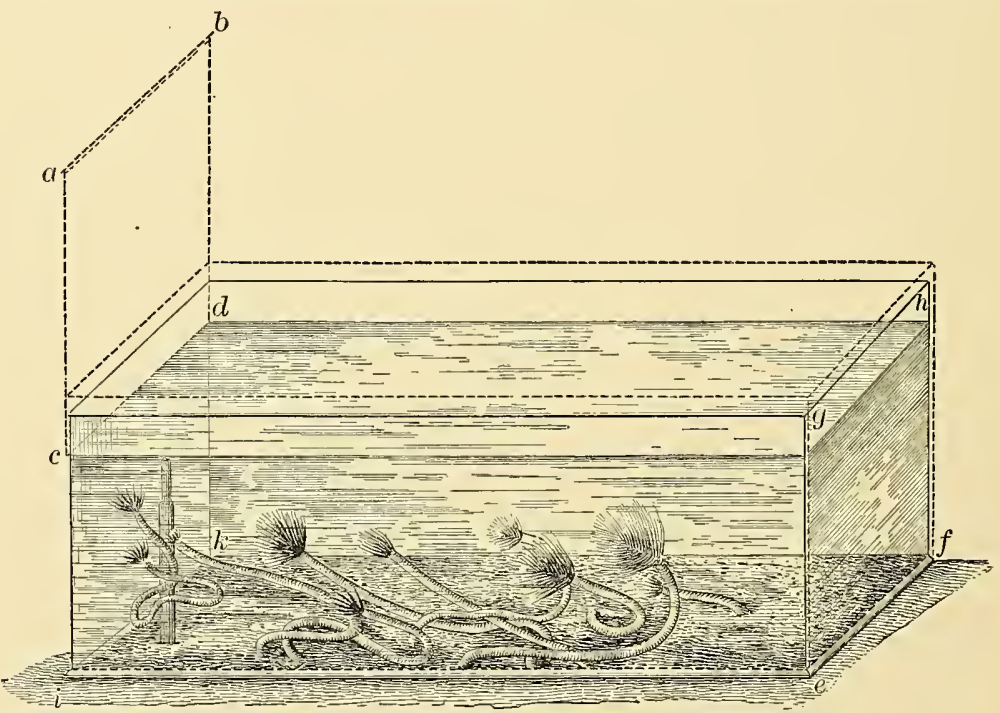

FIG. 127. - Persistent phototropic curvature in Spirographis spallanzanii. The animals were originally placed horizontally on the bottom of the aquarium, the majority with their heads towards the side, efgh, of the aquarium away from the window. In their further growth the animals curve until their heads are turned towards the light side, abcd, of the aquarium, and the axes of their gills stand in the direction of the rays of daylight. (From Loes, '90.)

builds, from a secretion of the body, cylindrical tubes of somewhat elastic nature which are attached at their base to a solicl substratum. When these worms, in their tubes, are illuminated from one side by a pencil of rays, the upper part of the tube comes, within a few hours, to lie in the axis of the pencil, and the gills, which surround the head, are stretched out towards the source of light. This result seems to be due to a sort of phototactic response modified by the sessile habit of 
the organism. Since the tube is tough and elastic, its bending towards the light must be due, at first, to muscular action of the animal inhabiting it. Additional secretions are, however, constantly poured forth so that the new position soon becomes in turn the permanent one. Serpula, which has a tube containing lime, likewise turns its head end towards the light; but, since its tube is firm and inelastic, the bending which it finally exhibits must be ascribed alone to growth of the shell by additions to its free upper margin.

b. Hydroids. - These have been made the object of study by Driesch ('90) and LoEB ('90 and '91, p. 36). In stocks of Sertularella polyzonias, reared in an aquarium, one often finds a stolon (primary stolon) growing out from the distal end, at first straight, so as to prolong the axis of the stock, then turning and growing from the source of light. From the convexity of this primary stolon a secondary one

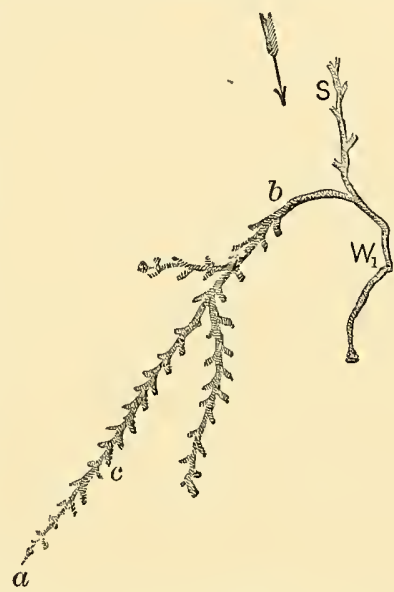
buds forth. It grows towards the Fig. 128. - Phototropism in relight for a time, until it in turn buds off a (tertiary) stolon; then it becomes negatively phototropic. Tertiary and succeeding generations of stolons follow the same law. We have here the remarkable phenomenon of change in the sense of response depending upon the condition of development of the stolon (Driesch), In Eudendrium the hydranths, in contradistinction to the stolons, grow towards the light - they are positively phototropic (Fig. 128).

generation of Sertularia (polyzonias?). The stock was cut near the stolon at $b$ and inserted reversed in the sand, being buried from $a$ to $c$. From the upper end $b$, both a stolon, $W_{1}$, and hydranths, $S$, regenerated, and both grew in the axis of the infalling ray of light, indicated by the arrow. The hydranths are directed toward the sonree of light; the stolon tip in the opposite direction. Magnified 2 diameters. (From LoEB, '90.)

The effective rays in animal phototropism have not been determined. It is highly probable that, as in plants, they are the more highly refractive ones. The responding region in hydroids is the growing region. The fully formed stolon does not turn in response to light. The pereeiving region is still 
unknown; the subject has not been investigated. Is it at the tip or at the responding region, or do these regions exactly coincide? The essential identity of phototropism in sessile animals and plants is striking, and indicates how closely similar needs are met by similar capacity for response in the two groups.

3. General Considerations. - $a$. Persistence of Stimulation. If a seedling, after momentary illumination on one side, be placed in the dark before any turning has occurred, phototropism will follow after the same interval as would have elapsed had the plant remained in the light. Even if the irritated seedling be placed in the dark in a horizontal position, no geotropic curvature will interfere with the working out of the stimulus already given. This persistence of an effect wrought by light has been called by WIESNER photomechanical induction : it is, however, only a particular case of persistence of an effect, of which we have seen other examples. As a result of this phenomenon a seedling, intermittently illuminated for one second and kept in the dark for two seconds, will respond phototropically as completely and as quickly as if it had been kept continuously in the light.

b. Acclimatization to light is a process closely related to the foregoing. As early as 1827 MoHL observed that plants reared in a weak light, or in the dark, became, after a time, phototropically more sensitive than plants which had been constantly exposed to full daylight. The observation has been several times confirmed (ef. DARwin, '81, Chapter IX); so we may conclude that the constant subjection to light diminishes the sensitiveness towards light.

c. Mechanics of Phototropism. - It is clear that phototropic curvature, as seen in the seedling, the mold, or the hydroid, is the result of unequal growth upon the two sides of the cylindrical organ ; and, indeed, that the positive phototropism is due to a relative diminution of growth on the side next the source of light, and the negative phototropism to a relative increase of growth on that side. Experiments have shown that in positive phototropism growth is excessively rapid upon the convex side of the organ, and excessively slow upon the concave side. These results are reasonably attributed to an 
increased turgescence on the one side and a decreased turgescence on the other.

In unicellular organisns, on the other hand, this mechanism cannot be called upon; and great difficulty has been met with in explaining how an elongated cell, for instance, of a hypha, can curve itself. Some authors have suggested that the cell-wall on the convex side becomes excessively extensible, on the concave side excessively rigid. Again, it has been suggested that this cliange takes place rather in the protoplasm inside the wall than within the wall itself. If, hovever, with many plant physiologists we regard the cell-wall as the truly living, only consiclerably modified, protoplasm, then we may accept both of these views, and, uniting with them the explanation advanced for phototropism in multicellular organs, say: The curving of the unicellular organ is probably due to the increased extensibility, gained through imbibition of water, of the whole protoplasm (including cell-wall) of the convex side, together with a corresponding diminution on the concave side. In a word, then, the mechanism of phototropism may be stated to be the excessively rapid imbibition of water by the protoplasm on the convex side.

But what starts the mechanism? This is the same question that arises with other growth responses. Its answer must be deferred to a later chapter.

\section{LITERATURE}

Adrianowsky, A. 'S3. Wirkung des Lichtes auf das erste Keimungsstadium der Samen. [Russian.] Abstr. in Bot. Centr. XIX, 73-75.

Aducco, V. '89. Action de la lumière sur la durée de la vie, la perte de poids, la température et la quantité de glycogène hépatique et musculaire chez les pigeons soumis au jeûne. Arch. Ital. de Biol. XII. 208-214. 28 July, 1889.

BAry, A. De, '63. Recherches sur le développement de quelques champignons parasites. Ann. d. Sci. Nat. (Bot.). (4), XX, 5-148.

Beclard, J. '58. Influence de la lumière sur les animaux. Comp. Rend. XI,VI, 441-453.

Bert, P. 72. Influence des divers rayons colorés sur la végétation. C. R. Soc. Biol. Paris. XXIII, 67-69.

'78. Influence de la lumière sur les êtres vivants. Revue Sci. (2), VII, 981-990. 20 Apr. 1878. 
Bidder, F. II., and Scmumt, K. '52. Die Verdaunngssäfte und der Stoffwechsel. $413 \mathrm{pp}$. Mitau and Leipzig, 1852.

Blanc, L. '92. Note sur les effets teratogéniques de la Iumière blanche sur l'œuf de poule. C. R. Soc. de Biol. Paris. XLIV, 969-971.

Borodin, J. '6s. Ueber die Wirkung des Lichtes auf einige höhere Kryptogamen. Bull. Acad. Sci. St. Petersburg. XII, 432-447. 1 Taf. 13 Jan. 1868.

Braeir, F. '95. Mittheilung über den Einfluss des Gefrierens auf die Entwickelung thierischer Keime. Jahresber. der Schlesischen Gesellsch. f. Vaterländ. Cultur. LXXII². Zool. Bot. Sect. 2-3.

Brefeld, O. '77. Botanische Untersuchungen über Schimmelpilze. III. Hft. Leipzig: Arthur Felix. 1877.

'89. Untersuchungen aus dem Gesammtgebiete der Mykologie. Fortsetzung der Schimmel und Hefenpilze. VIII. Hft. Leipzig: Arthur Felix.

Bullot, G. '97. Sur la croissance et les courbures du Phycomyces nitens. Ann. Soc. Belg. de Micros. XXI, 69-93. 1897.

Camerano, L. '93. Dell' azione dell' acqua corrente e della luce sullo sviluppo degli Anfibi anuri. Boll. Mus. Zool. ed Anat. Comp. Torino. VIII, 3-12. 20 Jan. 1893.

DARwin, C. and F. '81. (See Chapter XIV, Literature.)

Davidson, J. '85. On the Influences of Some Conditions on the Metarnorphosis of the Blow-fly (Musca vomitoria). Jour. of Anat. and Physiol. XIX, 150-165. Jan. 1885.

Driesch, H. '90. Heliotropismus bei Hydrö̈denpolypen. Zool. Jahrb., System. Abth. V, 147-156. 3 May, 1890.

'91. Entwickelungsmechanische Studien, II. Über die Beziehungen des Lichtes zur ersten Etappe der thierischen Formbildung. Zeitschr. f. wiss. Zool. LIII, 160-184. 10 Nov. 1891.

Edwards, IV. F. '24. De l'influence des agens physiques sur la vie. Paris, 1824. Also, On the Influences of Physical Agents on Life. Translated from the French by Dr. Hodgkins and Dr. Fischer. London, 1832.

Fanintzin, A. '65. Die Wirkung des Lichtes auf das Wachsen der Keimenden Kresse. Mém. Acad. St. Petersb. (7), VIII. No. 15.16 pp.

'67. Die Wirkung des Lichtes auf Algen und einige ihnen nahe verwandte Organismen. Jahrb. f. wiss. Bot. VI, 1-44.

Figdor, W. '93. Versuche über die Heliotropische Empfindlichkeit der Pflauzen. Sitzungsber. Akad. Wiss. Wien. CII ${ }^{1}, 45-59$.

Flaminarion, C. '95. Étude de l'action des diverses radiations die spectre solaire sur la végétation. Comp. Rend. CXXI, 957-960. 16 Dec. 1895.

Fries, E. M. '21. Systema Mycologicum, etc. I. 520 pp.

Gautier, A. '95. Discussion on Flammarion, ’95. Comp. Rend. CXXI, $960-961$.

Godlewsкi, E. '90. Die Art und Weise der wachsthumretardirenden Lichtwirkung und die Wachsthumstheorien. Anz. d. Akad. d. Wiss. Krakau, July, 1890, p. 286. [Abstr. Naturw. Rundschau. VI, 150, 151. 21 March, 1891.] 
Godlewski, E. '93. Studien über das Wachsen der Pflanzen. Abh. Krakauer Akad.d. Wiss. XXIII,1-157. [Polish.] Abstr.in Bot. Centr. LV, 34-40. Hales, S. 1727. Statical Essays. Volumen I: Vegetable Staticks, or an Account of Some Statical Experiments on the Sap in Vegetables. 376 pp. 19 Tab. London.

Hammond, '73. Some Points relative to the Sanitary Influence of Light. The Sanitarian, II.

Hensen, V. and Apstein, C. '97. Ueber die Eimenge der im Winter laichenden Fische. Wiss. Meeresuntersuch. deutsch. Meere. II, Heft 2, pp. 1-98.

Higgenbottom, J. 'כ0. Influence of Physical Agents on the Development of the Tadpole, of the Triton, and the Frog. Phil. Trans. Roy. Soc. London for 1850. 431-436. Pl. XXXII.

'63. Influence des agents physiques sur le développement du têtard de la grenouille. Jour. de la Physiol. VI, 204-210.

Hochreutiner, G. '96. Physiologie des plantes aquatiques du Rhône et du Port de Genève. Rev. Gén. de Bot. VIII, 148-167, 18s-200, 249-265. 15 Apr.-15 June, 1896.

Hoffmans, H. '60. Untersuchungen über die Keimung der Pilzsporen. Jahrb. f. w. Botanik. II, 267-337.

JöNssor, B. '93. Iakttogelsen öfver ljusets betydelse för fröns groning. Lunds Universitets Års-skrift. XXIX, 47 pp.

Karsten, H. '71. Die Einwirkung des Lichts auf das Wachsthum der Pflanzen, beobachtet bei Keimung der Schminkbohnen. Landw. Versuchs-Stat. XIII, 176-195.

Kry, L. '84. Das Wachsthum des Thallus von Coleochæte scutata in seinen Beziehungen zur Schwerkraft und zum Lichte. Ber. Bot. Ges. II, 93-96.

Kraus, G. '76. Versuche mit Pflanzen im farbigen Licht. Ber. Sitzungs d. Naturf. Ges. Halle. Jahre 1876. 4-8.

'83. Ueber das tägliche Wachsthum der Früchte. Ber. d. Naturf. Ges. zn Halle. 1883. 92-121.

LeitgeB, H. '77. Die Keimung der Lebermoossporen in ihrer Beziehung zum Lichte. Sb. Wien. Akad. LXXIV, 1 Abth. 425-436. 1 Taf.

Lessona, '77. Studê sugli amfibî anuri del Piemonte. R. Accad. dei Lincei Atti. (3) Mem. Sci. I, 1019-1095. 5 Tav.

Liebenberg, A. Ritter von, 'S4. Ueber den Einfluss intermittender Erwärmung auf die Keimung der Samen. Bot. Centralb. XVIII, 21-26.

Lоев, J. '90. Weitere Untersuchungen über den Heliotropismus der Thiere und seine Uebereiustimmung mit dem Heliotropismus der Pflanzen. Arch. f. d. Ges. Physiol. XLVII, 391-416. Taf. IX. 9 May, 1890.

'91. Untersuchung zur physiologischen Morphologie der Thiere. I. Ueber Heteromorphose. Würzburg: G. Hertz. 1891.

MIcDonnell, R. 'ŏ9. Exposé de quelques expériences concernant l'influence des agents physiques sur le développement du têtard de la grenouille commune. Jour. de la Physiol. II, 625-632. 
Massart, J. '88. Recherches sur les organismes inférieurs. 1. La loi de Weber vérifiće pour l'héliotropisme du champignon. Bull. Belg. Acad. (3), XVI, 590-597.

Maupas, É. '87. Sur la puissance de multiplication des Infusoires ciliés. Comp. Rend. CIV, 1006-1008. 4 Apr. 1887.

MIn.DE, J. '52. Zur Entwicklungsgeschichte der Equiseten und Rhizokarpen. Verh. d. Kais. Leop.-Car. Ak. d. Naturf. XV, 2 Abth. 613-646. Taf. $57-59$.

Millet, C. '55. Influence nuisible de la lumière sur les œufs de certaines especès de Poissous. L'Institut. XXIII ${ }^{1}, 55.14$ Feb. 1855.

Mонц, H. v. '27. Ueber den Bau und das Winden der Ranken-und Schlingpflanzen. 152 pp. 13 Tab. Tübingen, 1827.

Моцеsснотт, J. 'כ5. Recherches sur l'influence de la lumière sur la production de l'acide carbonique par les animanx. Ann. d. Sci. Nat. (Zool.). (4), IV, 209-224.

MÜLLer, H. 76. Ueber Heliotropismus. Flora. LIX, 65-70, 88-95.

Musset, C. '90. Sélénétropisme. Comp. Rend. CX, 201-202. 27 Jan. 1890.

Noвbe, F. '82. Uebt das Licht einen vortheilhaften Einfluss auf die Keimung der Grassamen? Landw. Versuchs-Stat. XXVII, 347-355.

Pleasonton, A. J. 76. The Influence of the Blue Ray of the Sunlight and of the Blue Color of the Sky in developing Animal and Vegetable Life, in arresting, and in restoring Health in Acute and Chronic Disorders to Human and Domestic Animals. Philadelphia, 1876.

Praxtl, K. '73. Ueber den Einfluss des Lichts auf das Wachsthum der Blätter. Arb. a. d. Bot. Inst. Würzburg. I, 371-384.

Quincke, H. '94. Ueber den Einfluss des Lichtes auf den Thierkörper. Arch. f. d. ges. Physiol. LVII, 123-148. 1 June, 1894.

Rother', W. '94. Ueber Heliotropismus. Beiträge zur Biol. der Pflanzen. VII, 1-212.

Sachs, J. '63. Ueber den Einfluss des Tageslichts anf Neubildung und Entfaltung verschiedener Pflanzenorgane. Bot. Ztg. XXI, Suppl. $30 \mathrm{pp}$.

'64. Wirkungen farbigen Lichts auf Pflanzen. Bot. Ztg. XXII, 353 et seq.

'72. Ueber den Einflnss der Lufttemperatur und des Tageslichts auf die stundlichen und täglichen Aenderung des Längenwachsthums (Streckung) der Internodien. Arb. a. d. Bot. Inst. Würzburg. I, 99-192.

Scnмıтz, J. '43. Beiträge zur Anatomie und Physiologie der Schwämme. Linnæa. XVII, 417-548.

Schnetzler, J. B. '74. De l'influence de la lumière sur le développement des larves de grenouilles. Arch. Sci. Phys. et Nat. LI, 247-258.

Sieners, C. W. '80. On the Influence of Electric Light upon Vegetation, and on Certain Physical Principles involved. Proc. Roy. Soc. XXX, 210-219.

'80a. Some Further Observations on the Influence of Electric Light upon Vegetation. Proc. Roy. Soc. XXX, 293-295. 
Siemens, C. IW.'82. On Some Applications of Electric Energy to Horticultural and Agricultural Purposes. Rept. Brit. Assoc. Adv. Sci. LI, 474-480.

Stameroff, K. '97. Zur Frage über den Einfluss des Lichtes auf das Wachsthum der Pflanzen. Flora. LXXXIII, 135-150. 22 Feb. 1897.

Stebler, '81. Ueber den Einfluss des Lichtes auf die Keimung. Vierteljahrs. Naturf. Ges. Zürich. XXVI, 102-104.

Trew, C. T. 1727. Beschreibung der grossen Amerikanischen Aloe, wobei das tägliche Wachsthum des Stengels der im Jahr 1726, zu Nürnberg verblühten Aloe erläutert wird. $36 \mathrm{pp.} 1$ Tab. Nürnberg, 1727.

Vernon, H. M. '95. The Effect of Environment on the Development of Echinoderm Larvæ: An Experimental Inquiry into the Causes of Variation. Phil. Trans. Roy. Soc. London. CLXXXVI ${ }^{\mathrm{B}}$, 577-632. $1 \pm$ Oct. 1895 .

Villon, A. M. '94. La culture sous verres colorés. Rev. Sci. (4), I, 460463. 14 A pr. 1894 .

Vines, S. H. '78. The Influence of Light upon the Growth of Unicellular Organs. Arb. Bot. Inst. Würzburg. II, 133-147.

WARD, H. M. '95. On the Biology of Bacillus ramosus (Fraenkel), a Schizomycete of the River Thames. Proc. Roy. Soc. LVIII, 265-468.

Whipple, G. C. '96. Some Experiments on the Growth of Diatoms. Technology Quarterly. IX, 145-168.

Wissner, J. '79. Die heliotropischen Erscheinungen im Pflanzenreiche. Eine physiologische Monographie. Theil I. Denkschr. Wien. Akad. XXXIX, 143-209.

'81. The same. Theil II. Denkschr. Wien. Akad. XLIII, 1-92.

'93. Photometrische Untersuchungen auf Pflanzenphysiologischen Gebiete. Erste Abhandlung. Orientierende Versuche uber den Einfluss der sogenannten chemischen Lichtintensität auf den Gestaltungsprocess der Pflanzenorgane. Sb. Wien. Ak. CII ${ }^{1}, 291-350$.

'98. Uéber die Ruheperiode und über einige Keimungsbedingungen der Samen von Viscum album. Ber. Deut. Bot. Ges. XV, 503-516.

Yung, E. '78. Contributions à l'histoire de l'influence des milienx physiques sur les êtres vivants. Arch. Zool. Expér. et Gén. VII, 251-282.

'80. De l'influence des lumières colorées sur le développement des animanx. Mitth. a. d. Zool. Stat. zu Neapel. II, 23:3-237.

'92. De l'influence des lumières colorées sur le développement des animaux. Comp. Rend. CXV, 620, 621. 24 Oct. 1892. 


\section{CHAPTER XVIII}

\section{EFFECT OF HEAT ON GROWTH}

As in other cases, so in describing the effect of heat we shall consider separately its effect on the rate and on the direction of growth.*

\section{§ 1. Effect of Heat on the Rate of Growth}

The descriptive fact that the rate of growth - of development in general - in both animals and plants is dependent upon temperature, has long been known. The work upon plants was begun earlier than that upon animals, and has been carried further. We may consider, first, the results gained in that group.

1. Plants. - As an introduction to the study of the effect of heat upon growing plants, we may consider the results of measurements made upon phanerogams, showing, for various temperatures, the increase in length of the plant after 48 hours :

* The methods to be employed in subjecting organisms to heat have already been discussed on pp. 219-222. The constant-temperature oven, of the kind employed in bacteriological laboratories, may be used for rearing growing plants or aquatic animals at a high temperature. An ordinary refrigerator will serve for temperatures from near $0^{\circ}$ to $8^{\circ}$ or $10^{\circ} \mathrm{C}$. The methods employed in thermotropic experimentation are referred to on p. 464 .

To test the question of the dependence of the optimum for growth upon the temperature to which the organism is normally subjected it would be necessary to rear a species attuned to a warm climate at a constantly low temperature for several generations, or the reverse, and then compare the optimum of the normal race with that subjected to the new conditions. To test the question of the dependence of the range of the growing temperatures upon the range of temperatures in the environment, one lot of individuals of a species should be reared in a constant-temperature room, and another in a very fluctuating temperature. 


\section{TABLE XLVII}

Showing the Average Total Ixcrements in Lexgth (in Millimeters) of the Plumules of Seedlings subjected to Different Temperatures (expressed in Degrees Centigrade). The Observations marked $S$ Were Made by SaChS ('60); those MaRKed K, BY Köppex ('71) ; aND those marked V, by de Vries (' 70 ). The Time Interval is 48 Hours

\begin{tabular}{|c|c|c|c|c|c|c|c|c|c|}
\hline Temperature. & 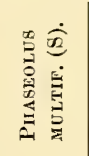 & 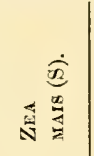 & 商 & 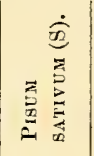 & 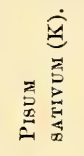 & 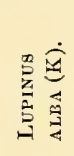 & 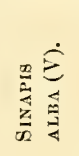 & 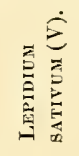 & 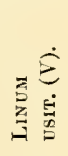 \\
\hline $14-15.9$ & & & & & 5.0 & 9.1 & 3.8 & 5.9 & 1.5 \\
\hline $16-17.9$ & $7.4 *$ & $4.6 *$ & & $3.0 *$ & & & & & \\
\hline $18-19.9$ & & & 1.1 & & 8.3 & 11.6 & & & \\
\hline $20-21.9$ & & & 9.3 & & 25.5 & 25.0 & 24.9 & 38.0 & 20.5 \\
\hline 22-23.9 & & & 10.8 & & 30.0 & 31.0 & & & \\
\hline $24-25.9$ & & & 20.1 & & 45.8 & 33.9 & & & \\
\hline $26-27.9$ & 11.0 & 5.6 & 29.6 & 10.0 & 53.9 & 54.1 & 52.0 & 71.9 & 44.8 \\
\hline $28-29.9$ & & & $26.5 ?$ & & 40.4 & 50.1 & & & \\
\hline $30-31.9$ & & & 64.6 & & 38.5 & 43.8 & 44.1 & 44.6 & 39.9 \\
\hline $32-33.9$ & 10.5 & 11.0 & 69.5 & 5.7 & 23.0 & 14.2 & & & \\
\hline $34-35.9$ & 15.0 & 13.0 & & 5.0 & & & 30.2 & 26.9 & 28.1 \\
\hline $36-37.9$ & & & 20.7 & & 8.7 & 12.6 & 10.0 & 0.0 & 9.2 \\
\hline $38-39.9$ & 10.2 & 9.1 & & 5.5 & & & & & \\
\hline 42.5 & 7.5 & 4.6 & & & & & & & \\
\hline
\end{tabular}

\section{TABLE XLVIII}

Showing the Average Increments in Length in Millimeters of the Radicle of Various Seedixg Plants subjected to Different 'Temperatures. Temperatures in Degrees Centigrade. All from Sachs ('60). The Time Interval is 48 Hours.

\begin{tabular}{|c|c|c|c|c|}
\hline$\circ \mathrm{C}$ & ZEA MAIS. & $\begin{array}{c}\text { Phaseolds } \\
\text { MULtiflorus. }\end{array}$ & CUCURBITA PEPO. & Pisem satives. \\
\hline 17.0 & $2.5 *$ & & & 4.0 * \\
\hline 25.7 & & 39 & & \\
\hline 26.3 & 24.5 & 47 & & \\
\hline 28.5 & & 34 & & 41.0 \\
\hline 33.2 & 39.0 & 30 & & 17.0 \\
\hline 34.0 & 55.0 & 28 & 30 & \\
\hline 38.2 & 25.2 & 22 & 14 & 12.2 \\
\hline 42.5 & 5.9 & 7 & 11 & \\
\hline
\end{tabular}

* Growth during 96 hours. 
Data from the higher fungi have been afforded by the studies of Wiesner ('73) upon Penicillium. I give all of IVIEsNer's data, although not all are strictly concerned with growth. These data show the relation between temperature, on the one hand, and the interval, in days, between sowing and (1) germination, (2) formation of visible mycelium, and (3) spore formation, on the other:-

TABLE XLIX

Time, in Days, required for Spores of Penicillium to germinate, produce

Visible Mŕcelium, and to form Spores, at Various Temperatures

\begin{tabular}{|c|c|c|c|}
\hline Temperature ${ }^{\circ} \mathrm{C}$. & Tine to Germination. & $\begin{array}{l}\text { Thae to Production } \\
\text { of Visible Miscelium. }\end{array}$ & $\begin{array}{l}\text { Time to Spore } \\
\text { Formation. }\end{array}$ \\
\hline 1.5 & 5.80 & & \\
\hline 2.0 & 5.50 & & \\
\hline 2.5 & 3.00 & 6.00 & \\
\hline 3.0 & 2.50 & 4.00 & 9.00 \\
\hline 3.5 & 2.25 & 3.50 & 8.00 \\
\hline 4.0 & 2.00 & 3.00 & 7.75 \\
\hline 5.0 & 1.50 & 2.90 & 7.00 \\
\hline 7.0 & 1.20 & 3.00 & 6.25 \\
\hline 11.0 & 1.00 & 2.30 & 4.00 \\
\hline 14.0 & 0.75 & 2.00 & 3.00 \\
\hline 17.0 & 0.75 & 2.00 & 3.00 \\
\hline 22.0 (Opt.) & 0.25 & 1.00 & 1.50 \\
\hline 26.0 & 0.50 & 0.99 & 2.00 \\
\hline 32.0 & 0.70 & 1.01 & 2.10 \\
\hline 38.0 & 0.55 & 2.25 & 2.60 \\
\hline 40.0 & 0.70 & 2.50 & 3.50 \\
\hline
\end{tabular}

The law of growth of bacteria at various temperatures is illustrated in the observations of WARD ('95, p. 458). His results are epitomized in the curves of Fig. 129.

The curve (Fig. 130) of the phanerogams Zea mais and Pisum sativum, which is constructed somewhat differently from that of

Fig. 129. - Curve of relation between rate of growth of Bacillus ramosus and the temperature. The growth is measured by the period, expressed in minutes $(\mu)$, required for the bacillus to double its length. The relative duration of these periods is expressed by the ordinates. The abscissæ are temperatures. (From WARD, '95.)

FIg. 130. - Curves of absolute growth in 48 hours of Zea mais and Pisum sativum at different temperatures. (Data from Table XLVII.) 


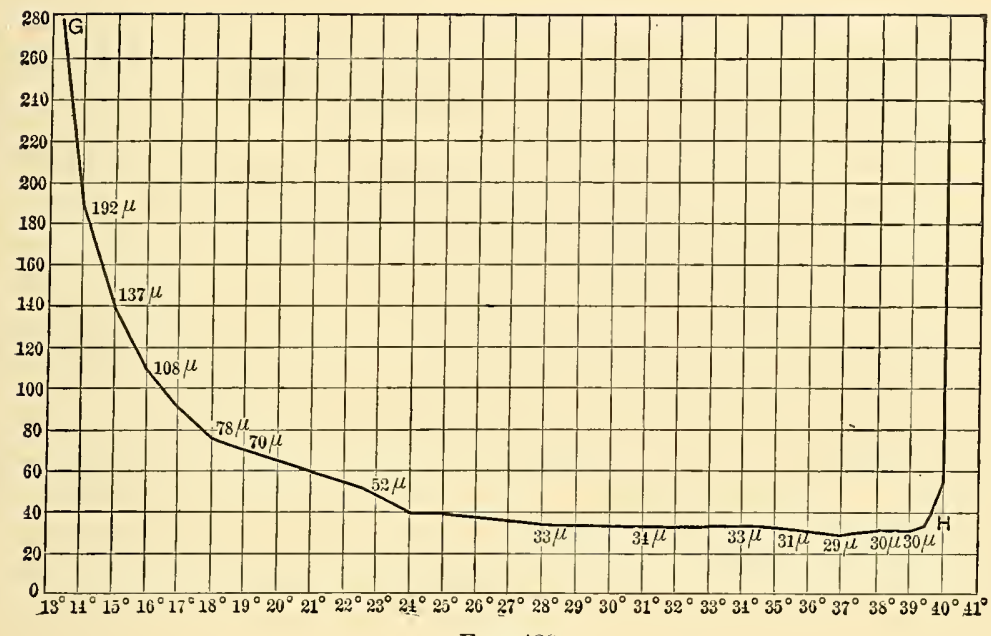

FIG. 129

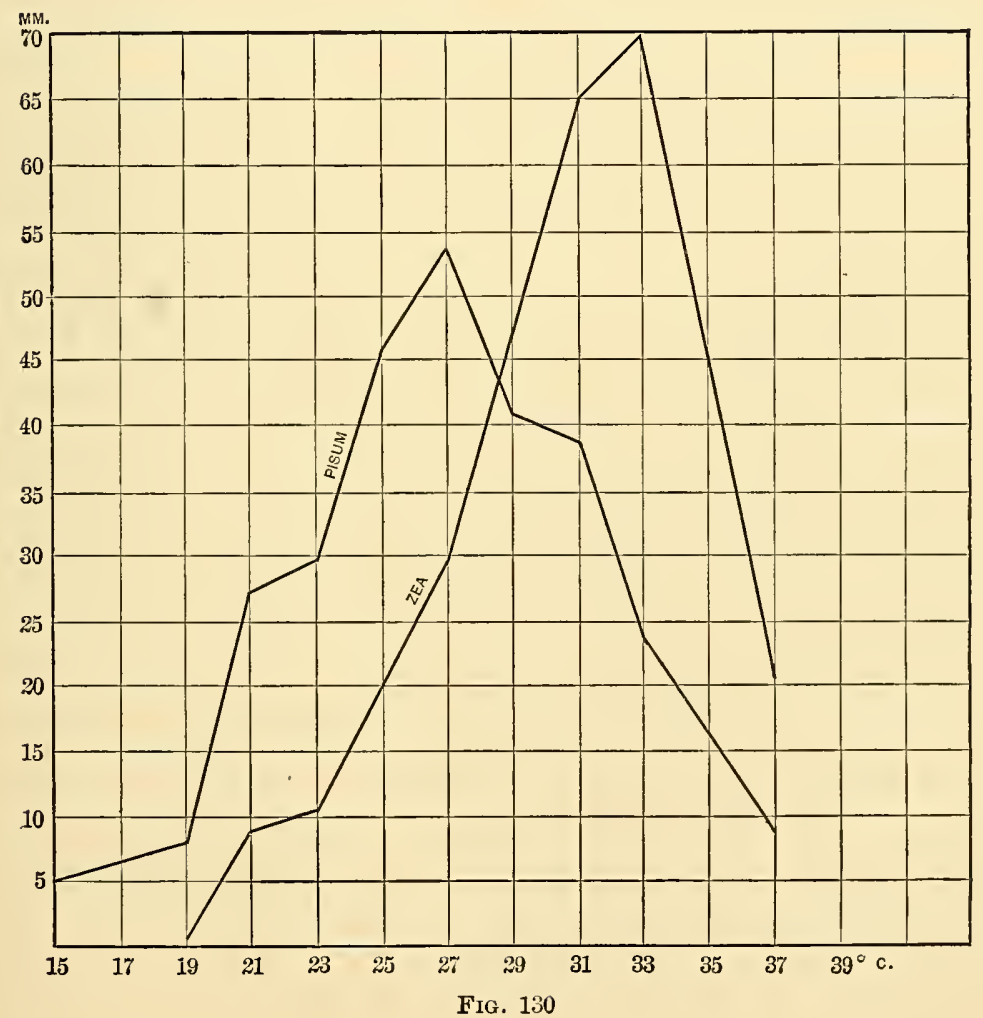


Fig. 129, shows, more graphically than the tables from which they are drawn, that, as the temperature rises, growth increases up to a certain point, and then diminishes again. The falling off is more rapid than the increase - a condition which we found also in the curves (Fig. 68 ; p. 226) giving the rate of movement of protoplasm at different temperatures. We have thus three critical points to distinguish: the minimum, or lowest temperature at which growth occurs; the optimum, or the temperature of greatest growth; and the maximum, or the highest temperature at which growth can take place. These critical points, then, are to be considered comparatively; and as an introduction to this consideration I present, in a table, the points as they have been determined for various species :-

TABLE L

Showing Critical Points for Various Plant Organisus, arranged ACCORDING TO THE OptimuM

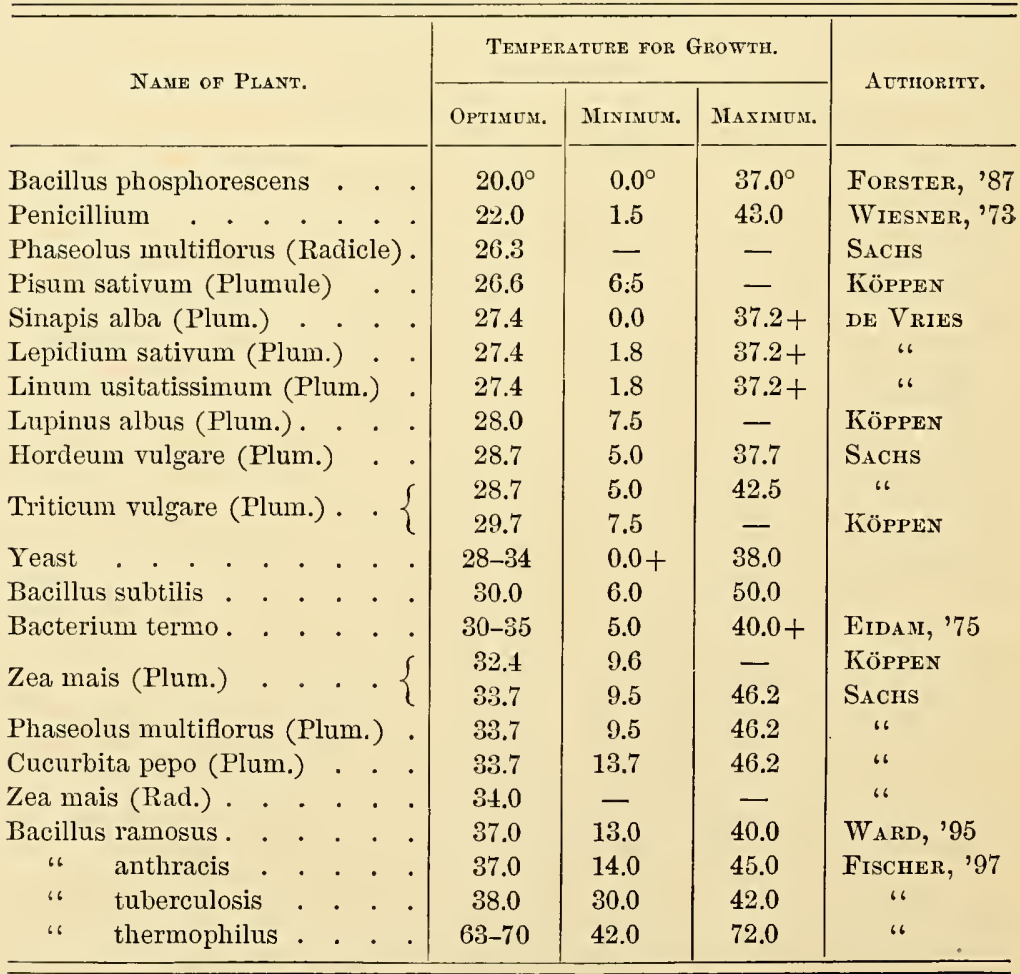


This table shows, first, that the optimum, minimum, and maximum are correlated; that when one is high or low the others are, in general, high or low also. It shows, moreover, that the position of the optimum varies greatly; so that the minimum of one species, Bacillus thermophilus, lies higher than the maximum of another, Bacillus phosphorescens. We see, also, that the bacteria have, among all organisms, the greatest variation in the optimum, for this ranges from $20^{\circ}$ to $63^{\circ}-$ $70^{\circ} \mathrm{C}$, or through $43^{\circ}-50^{\circ} \mathrm{C}$. In the various phanerogams the extreme range of the optimum is from $26.6^{\circ}$ to $33.7^{\circ} \mathrm{C}$, or through $7^{\circ}$. Again, the range of temperatures at which growth occurs in any one species varies greatly. The most striking feature of this table - the one which most needs accounting for - is its variety.

In respect to the optimum we find a certain relation between the degree of temperature of most rapid growth and that to which the organism is normally subjected. Taking the case of an organism with a low optimum, we find Bacillus phosphorescens living in the North Sea, and normally subjected to a low temperature; for, even in its southern part, the mean temperature of the North Sea is $17.5^{\circ}$ at the surface. Taking the case of organisms with a high optimum, we find Bacillus anthracis and Bacillus tuberculosis living in the mammalian body at a normal temperature of $35^{\circ}$ to $38^{\circ} \mathrm{C}$. 'These numbers lie near' the optima of the species. Bacillus thermophilus lives in fermenting manure and in other situations attaining a temperature of $60^{\circ}$ to $70^{\circ}$. Likewise, among phanerogams, we find a relation between the optimum and the normal temperature the maize and gourd are of tropical origin, while the white mustard (Sinapis) belongs to the temperate zone. That this agreement between optimum and normal temperature is not always close may be partly ascribed to the fact that many species of plants, especially cultivated plants which are usually employed in experimentation, have lived at different times under dissimilar environmental conditions. What, now, is the reason for this general parallelism between the optimum and the normal temperature? As in other cases, it can clearly be ascribed only to an attunement gained by the organism as a result of its subjection to the temperature. 
As for the minimum we find that, while it varies somewhat with the optimum, it never falls below $0^{\circ} \mathrm{C}$. The reason for this is clear ; for, as we have ahready seen (p. 241), $0^{\circ} \mathrm{C}$. is the minimum for most vital activities. The fact that the minimum for phanerogams is given some distance above $0^{\circ}$ is partly due to the fact that, since growth becomes very slow towards $0^{\circ}$, the absolute minimum for growth is hard to find. Kirchner ('83), who paid particular attention to this matter, concluded that the minimum temperature of both radicles and plumules of many seedlings lies between $0^{\circ}$ and $1^{\circ} \mathrm{C}$. However, we cannot ignore the fact that Cucurbita, for example, has a minimum for growth considerably above the point of cold-rigor; nor that, in pathogenic bacteria, the minimum is near the optimum of some free-living organisms. These facts teach us that the conditions for growth may be surpassed before metabolism has wholly ceased.

The maximum temperature tends to be rather constant; inside of the group of phanerogams the range is only from $37^{\circ}$ to $46^{\circ}$, or $9^{\circ}$. But $45^{\circ}$ to $46^{\circ}$ is a fatal temperature for most plant protoplasm (p. 234), and $50^{\circ}$ is the outside limit; hence the death-point (ultra-maximum) lies very close toonly slightly beyond - the maximum temperature for growth. It is probable that growth ceases where heat-rigor comes in. 'The extraordinarily high resistance of Bacillus thermophilus can create no surprise after our study of the capacity of organisms for acclimatization to temperatures near the boiling-point of water (p. 250). It is merely another striking case of the capacity of protoplasm for self-adjustment.

The range of growing temperatures varies, as we have seen, with the species. The greatest range in our table is that of Bacillus subtilis, $44^{\circ}$. It is tolerably uniform for phanerogams $\left(37^{\circ}\right.$ to $\left.32^{\circ}\right)$; but in bacteria we have a range of $38^{\circ}$ in the case of Bacillus phosphorescens to only $12^{\circ}$ in the case of Bacillus tuberculosis. Here, again, we see a relation between the vital peculiarities and the environment of the organism. B. phosphorescens lives on the surface of the sea, whose temperature varies with that of the air ; whereas B. tuberculosis lives in the mammalian body, whose temperature is nearly constant. It is interesting that the temperature of $42^{\circ}$, which is 
the maximum for B. tuberculosis of man, is likewise about the human ultra-maximum ; and $30^{\circ}$, the minimum for B. tuberculosis, is just below the human ultra-minimum. Thus the range of vital temperatures of this parasite is practically the same as that of its host.

To sum up, the critical temperatures of plants are wonderfully adjusted to their environment, not only in respect to the optimum for growth, but also in respect to the range within which growth is possible. The origin of this adjustment is, as the phenomena of acclimatization show, not to be sought in any process of selection, but in the modification wrought on the protoplasm by the temperature itself.

2. Animals. - We may begin our account of the effect of heat on the rate of growth of animals by a table, necessarily drawn from more limited data, but otherwise resembling Table XLVII.

\section{TABLE LI}

Showing for Different Temperatures the Absolute Increase in Length, measured in Millimeters, fron the 24th to the 48th Hodr after Hatching. Measurements made on Young Tadpoles of the Frog, Rana virescens, aNd the Toad, Bufo lentigivosus, by Lillie and Knowltow, '98

\begin{tabular}{|c|c|c|c|c|c|}
\hline \multirow{2}{*}{ TEMPERATURE. } & \multicolumn{2}{|c|}{ Average Growth. } & \multirow{2}{*}{ Temperature. } & \multicolumn{2}{|c|}{ Average Growth. } \\
\hline & Frog. & TOAD. & & Frog. & TosD. \\
\hline $9-10.9^{\circ}$ & 4.5 & 3.0 & $23-24.9^{\circ}$ & & 41.3 \\
\hline $11-12.9$ & 5.3 & 5.3 & $25-26.9$ & 31.5 & 39.0 \\
\hline $13-14.9$ & $4.3 ?$ & 15.5 & $27-28.9$ & 40.0 & \\
\hline $15-16.9$ & & 16.3 & $29-30.9$ & 47.5 & 56.8 \\
\hline $17-18.9$ & 9.5 & & $31-32.9$ & 40.2 & 55.3 \\
\hline $19-20.9$ & 19.8 & 21.2 & $33-34.9$ & 43.5 & \\
\hline $21-22.9$ & & & & & \\
\hline
\end{tabular}

Oscar Hertwig ('98) has determined the curves of growth for Rana fusca, and these are given in Fig. 131. These curves have not been carried beyond the optimum. (Compare Fig. 129.)

This table and the curves show plainly that the growth of organisms so remote as the maize plant and tadpoles are similarly affected by heat. In both cases there is a slow and con- 
stantly diminishing increment to the optimum, and then a rapid decline to the maximum.

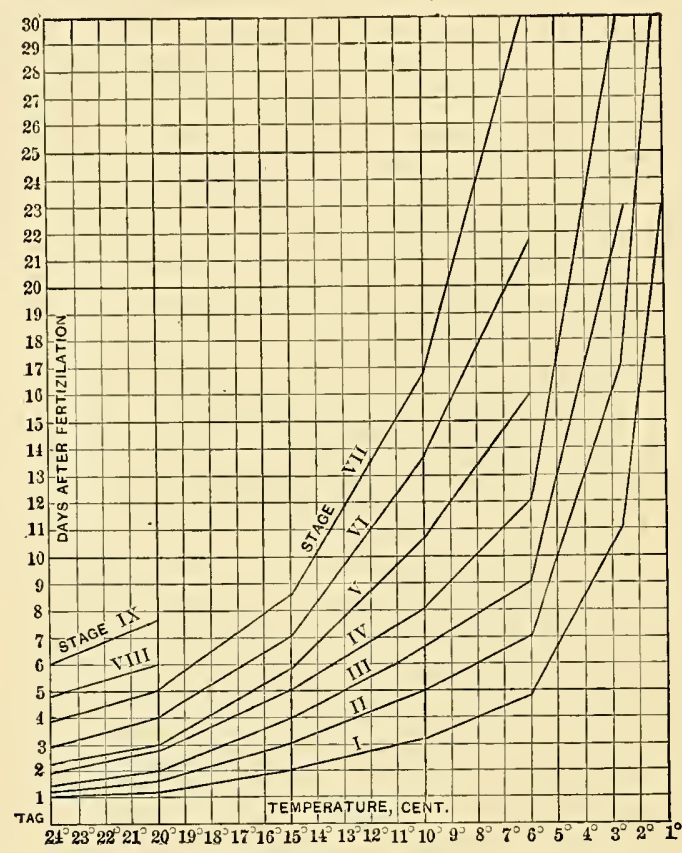

F1G. 131. - Curves showing the relation between the number of days (ordinates, indicated at left) required for the frog tadpole to reach a certain definite stage, and the temperature to which it is subjected during development. Stage I is that of a gastrula whose blastopore is just closing; II, edges of medullary plate rising ; III, medullary tube completely closed ; IV, tail evident, but gills not formed; V, embryo $5 \mathrm{~mm}$. loug; VI, embryo $7.5 \mathrm{~mm}$. long; VII, $9 \mathrm{~mm}$. long; VIII, 11 mm. long; IX, $11.5 \mathrm{~mm}$. long. (From Hertwig, '98.)
Although many observations upon the effect of heat on the grow th of animals have been made, they have been mostly fragmentary. I have gathered certain cases from the literature which it may not be useless to reproduce here.

Echinodermata. According to VERxoN ('95) the optimum for the development of Echinoid larva is $7^{\circ}-$ $22^{\circ}$.

Crustacea.-Nauplii of Branchipus and Apus hatch out at a temperature of $30^{\circ}$ in less than 24 hours, whereas at $16^{\circ}-20^{\circ}$ they require some weeks (Skmper, '81, p. 129). Lobster larvæ reared at $23^{\circ}$ to $27^{\circ} \mathrm{C}$. passed the fourth molt in about 10 days, or 3 days earlier than larvæ reared at $19^{\circ} \mathrm{C}$. (Herlick, '96, p. 190).

Insecta. - The migratory locust is asserted to require at different temperatures the following times for hatching. The figures are suspiciously regular. (From Cunnot, '94, p. 18, after "Cleveland.")

$\begin{array}{lllllllllllllll}\text { Degrees } & . & . & . & . & . & . & . & . & . & . & 25 & 20 & 15 & 10 \\ \text { Days } & . & . & . & . & . & . & . & . & . & . & 50 & 55 & 60 & 65\end{array}$

Fishes. - Many experiments have been made with these animals for commercial reasons, as it is sometimes desirable to retard growth during transportation or to delay hatching until the season of the natural enemies shall have been passed. Some of the results are summarized in 
TABLE LII

Showing for Three Species of Fish the Interval, in Days, elapsing between Fertilization and Hatching, at Various Temperatures

\begin{tabular}{c|c|c|c}
\hline \hline Temperature of Water. & Cod (Earla, '80). & Herrivg (Mejer, '78). & Shad (Rice, '84). \\
\cline { 2 - 4 }$-2-0.0$ & 30.0 & & \\
$0-1.9$ & 32.5 & & \\
$2-3.9$ & 22.0 & 40 & \\
$4-5.9$ & 16.0 & 15 & \\
$6-7.9$ & 13.0 & 11 & 11 \\
$8-9.9$ & & & $3-5$. \\
$10-11.9$ & & & \\
13.5 & & & \\
$20-23.0$ & & & \\
\hline
\end{tabular}

RAuber ('83) states that eggs of mimnows and salmon, which develop during the winter season, will not grow at much above $12^{\circ}-15^{\circ}$, but will do so at $0^{\circ}$. On the contrary, eggs which normally develop during the summer grow better at the higher temperatures.

Amphibia. - The European Rana is said not to develop at $0^{\circ}$ (Schultze, '94), and the same is true of the Amblystoma tigrinum of the United States. (Lillie and KNowltox, '98). The time required to attain a definite stage, at which the chorda is well developed and head and tail are sharply marked, is for Rana temporaria: at $15^{\circ}, 6$ days; at $33^{\circ}, 1$ day (Hertwi Ğ, '96). If brought gradually to it tadpoles may develop at $37^{\circ}$, or even for a few hours at $40^{\circ}$, but they do not thrive long at this temperature. The great effects of temperature on rate of development of the frog are illustrated by Fig. 132 .

Birds develop only at a high temperature and within narrow limits. The normal for the chick is $38^{\circ}$, the minimum is $25^{\circ}$, the maximum near $42^{\circ}$ (RAuber, '84). FÉrÉ ('91) has determined the rate of development of the chick's egg incubated at different temperatures. One lot at an abnormal temperature and a second at $38^{\circ}$ were reared synchronously; after a time the eggs were opened and the average stage of development (in hours of a standard series) determined. The following numbers express the ratio of the stage of development at the abnormal temperature to the stage at the normal temperature of $38^{\circ}:-$

$\begin{array}{lrccccccc}\text { Temperature . . . . } & 34^{\circ} & 35^{\circ} & 36^{\circ} & 37^{\circ} & 38^{\circ} & 39^{\circ} & 40^{\circ} & 41^{\circ} \\ \text { Index of Development } & 0.65 & 0.80 & 0.72 & ? * & (1.00) & 1.06 & 1.25 & 1.51\end{array}$

In summarizing these scattered observations on growing animals we may exhibit in one table their critical temperatures.

* The stage at $37^{\circ}$ is taken from too few observations to be trustworthy. The stages at $35^{\circ}$ and $36^{\circ}$ are irregular, doubtless because of too few observations. As we go beyond $41^{\circ}$ the ratio must decline again with great suddenness to 0 . 
TABLE LIII

Critical Points for Various Animals, arranged according to the Optimum

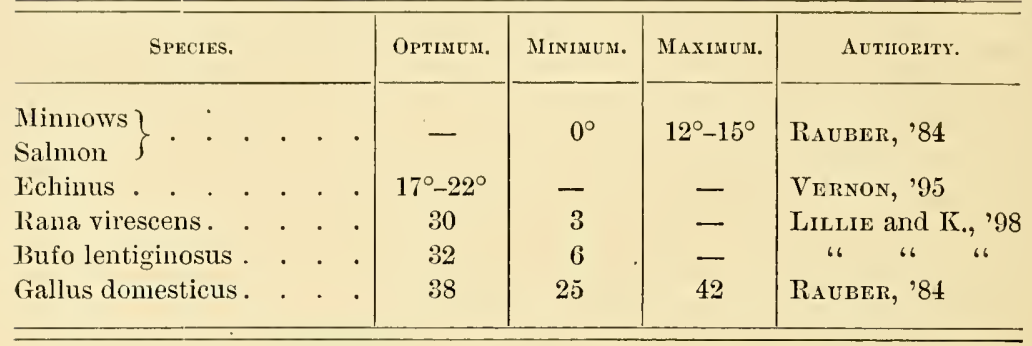

These critical points for animals show the same variations with reference to optima, minima, maxima, and range that those of plants do, and here also these variations are clearly adjusted to the temperatures normally experienced by the species.

\section{Some General Phenomena accompanying Heat Effects. -}

a. Latent Period. - We have seen that a change in the rate of growth is produced by a change in temperature. If, however, the times of the two changes be carefully noted, it will be found that a considerable interval elapses between them. This interval, the latent period, varies with the temperature. Thus Askenasy ('90, p. 75) found that, in the case of maize seedlings cooled to $1^{\circ}-5^{\circ}$, two or three hours elapsed before decreased growth occurred; whereas, when the seedling was cooled to $0^{\circ}$, five hours elapsed. . A similar effect follows a change in the reverse direction.

b. Sudden Change of Temperature. - If the radicle of a seedling is suddenly transferred from water at or near $0^{\circ} \mathrm{C}$. to water at between $18^{\circ}$ and $21^{\circ}$, two effects follow. The first appears immediately after the transference, and consists in the sudden elongation of the radicle. The second appears later, and consists in a growth which is slower than that of the normal radicle. These facts have been determined by TruE (95), who concludes that the first effect is of a physical nature, and is due to the fact that, at the higher temperature, osmotic pressure is greater; hence the tension in the tissues is greater and, consequently, they become stretched. The second effect TRue regards as a response to the stimulus of the change, since 
it is not constant for a given difference between the two temperatures, but is greater in raising the temperature from $5^{\circ}$ to $18^{\circ}$ than in raising from $17^{\circ}$ to $30^{\circ}$. The more abnormal one of the pair of temperatures is, the greater is the response.

c. Cause of Acceleration of Growth by Heat. - The acceleration of growth may be due either to increased assimilation, imbibition, or production of formed substance. Is it principally due to any one of these or are all increased in the same proportion? Data on this subject are afforded by certain measurements made by Bialoblocki ('71).

Seeds of rye, barley, and wheat were planted in soil which was fertilized by nutritive solutions and heated by a surrounding bath of water. The average absolute weight of the whole plant of each species was determined after the lapse of twenty days. The proportions of water, organic matter, and ash in the entire plant were likewise determined. Some of the results are given in Table LIV. It is to be noted that the high temperature was applied only to the soil in which the roots of the plant were imbedded.

\section{TABLE LIV}

Giving the Average Weigit (in Mildigrames) and the Percentage of Water in Plants whose Roots are maintained in Soll, at Various. Temperatures, for 20 Days (Bialoblocisi)

\begin{tabular}{|c|c|c|c|c|c|c|}
\hline \multirow[b]{2}{*}{ TEMPERATURE. } & \multicolumn{2}{|c|}{ Rixe. } & \multicolumn{2}{|c|}{ BARLEY. } & \multicolumn{2}{|c|}{ WHEAT. } \\
\hline & $\begin{array}{c}\text { Freshi } \\
\text { WeIGit } \\
\text { IN M!g. }\end{array}$ & $\%$ Water. & $\begin{array}{c}\text { FrEsh } \\
\text { WEIGHT } \\
\text { IN MG. }\end{array}$ & $\%$ Water. & $\begin{array}{c}\text { Fresh } \\
\text { WeIGHT } \\
\text { IN MIG. }\end{array}$ & $\%$ Water. \\
\hline $10^{\circ}$ & 176 & 87.1 & 156 & 88.4 & 131 & 84.1 \\
\hline 15 & 269 & 87.9 & 383 & 91.0 & 241 & 87.8 \\
\hline 20 & 459 & 89.1 & 409 & 91.0 & 261 & 88.2 \\
\hline 25 & 376 & 88.7 & 435 & 90.4 & 342 & 87.2 \\
\hline 30 & 408 & 88.4 & 365 & 90.0 & 402 & 88.3 \\
\hline 40 & 240 & 87.0 & 281 & 88.6 & 296 & 86.4 \\
\hline 88 & 192 & 87.5 & 152 & 88.7 & 98 & 83.9 \\
\hline
\end{tabular}

This table shows that the percentage of water increases slightly but constantly as the growth is accelerated by increased temperature, reaching a maximum near the optimum temperature. Other data (not reproduced here) show that the percentage of ash remains about constant, while that of dry organic sub- 
stance diminishes slightly towards the optimum temperature for growth. We conclude, consequently, that in the acceleration of growth by heat all three processes are accelerated, but the im-

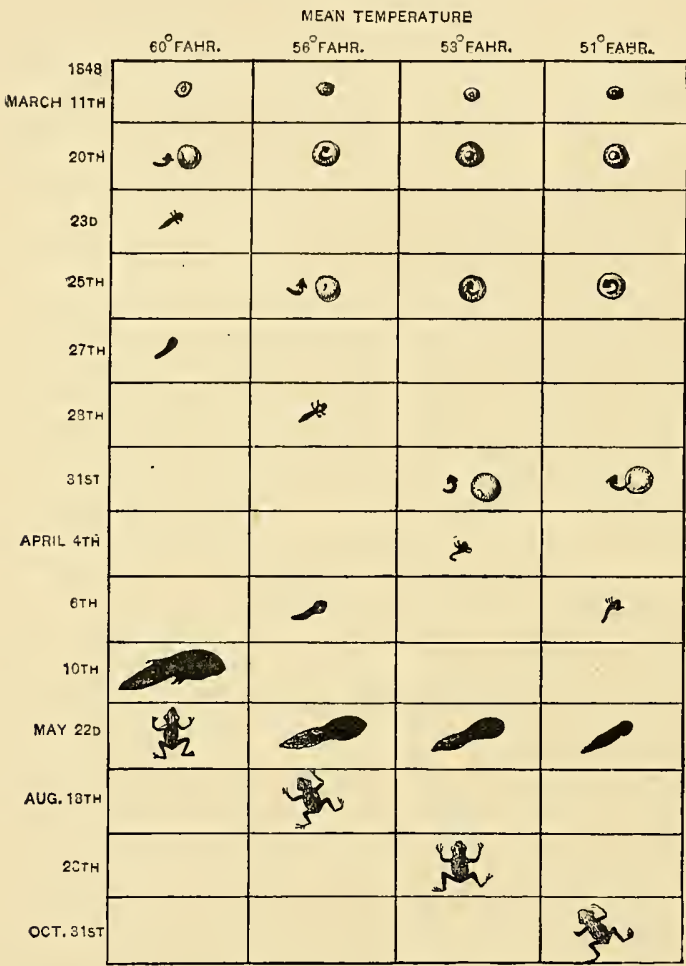

FIG. 132. - A chart showing the correlation between the stage of development of the frog on successive days and the temperature at which it has developed. (From HiggenвotToM, '50.)

bibitory process more than the others.

Apparently contradictory are the results gained by Coperand ('96), who found that the cells in the foliage of a moss which was transferred from a cold room at $2^{\circ}$ to a room at $18^{\circ}$ to $20^{\circ}$ lost, in from one to two weeks, a degree of turgescence measured by a 1 to $3 \%$ solution of potassic nitrate (p. 72). When returned to the cold room the cells gained an increased turgescence. The nearer the temperature lay to the optimum, the more rapid therefore the plant growth, the lower was the turgescence. This seeming paradox can be, explained upon the hypothesis that just because the whole tissue is expanding, just because the superficial increase of the organic walls keeps pace, or more than keeps pace, with that of the included water, there is less osmotic pressure in the rapidly growing plants than in the slow-growing ones where the plasma walls are not expanding as fast as the imbibitory process would demand. 
We may now gather together the results of our study of the effect of heat on the rate of growth of organisms. The relation between temperature and rate of growth may be expressed by a curve which, starting near $0^{\circ}$, reaches its highest point at a temperature varying with the species, and falls to a maximum temperature generally not far from the lethal temperature for the race. Three critical points are thus distinguishable, 一 the minimum, the optimum, and the maximum. In both animals and plants these points are correlated. The optimum lies close to the normal temperature for the species, the minimum lies usually only a little above the point of cold-rigor, and the maximum only slightly below the point of heat-rigor. The optimum lies nearer the maximum than the minimum, but the curve is not so unsymmetrical as that of metabolism. Any change in temperature leads to a change in the rate of growth, but this does not take place completely at once: there is a latent period of an hour or so. A sudden rise in temperature, especially from $0^{\circ}$ to the ordinary summer temperature, is accompanied not only by a mechanical (elongating) effect, but also by a physiological response, showing itself in accelerated growth. Finally, in the acceleration of growth by heat, the imbibition of water is slightly more accelerated than the other growth processes.

\section{§ 2. Effect of Heat on the Direction of Growth- ThernotropisM *}

Two sorts of heat are to be here distinguished - radiant and conducted. The former is a form of radiant energy and allied to light, consisting, indeed, of the rays lying beyond the visible red of the spectrum. The latter is due to molecular vibrations of the medium.

1. Effect of Radiant Heat. - When Phycomyces nitens or seedlings of Lepidium sativum, Zea mais, etc., are reared on a

* The first suggestion of this phenomenon was based upon an analogy with the action of light and was made by van Tieghem ('82), who gave it the name Thermotropism. Wortuann (' 83 and ' 85 ) first published extensive critical studies on the subject. Others who have contributed data are BarthelemY ('84), working on the roots of bulbous plants; VöcutıNG ('88), upon flower buds : and AF KLERCKER ('91) upon radicles. 
klinostat whose axis of rotation is parallel to the window, and are subjected to rays of heat from a warmed plate of iron held in the axis of rotation, they turn with reference to the source of heat. 'Thus Wormsuns found that, at a distance from the iron plate of $10 \mathrm{~cm}$., corresponding to a temperature of $27^{\circ} \mathrm{C}$., all the spore-bearing hypha of Phycomyces turned in seven hours from the source of heat; they were negatively thermotropic. Under the same conditions the plumule of a seedling maize was positively thermotropic. The roots of the hyacinth when growing in water turn towards the adjacent stove-pipe. The flower-buds of Magnolia turn, in the field, from the dark heat-rays of the sun (Vöchting).

2. Conducted Heat. - The methods employed in working with this agent have been as follows: Wortuans used a box divided into two compartments by a diathermous partition. Through one compartment there passed a constant current of cold water; the second was filled with sawdust in which seeds were imbedded. In front of this second compartment, on the opposite side from the cold-water chamber, was a gas flame, the source of energy. The seeds were scattered through the sawdust, so that some were nearer the flame, others nearer the cold hinder wall. The temperature of the sawdust near each seedling was determined. KLERCKER used essentially the same apparatus, excepting that a box of hot water replaced the flame.

The results of the experiments are summarized in

TABLE LV

Showing for the Radicles of Seedlings of Variods Species the Relation between the Temperature and the Sense of Thernotropic Response

\begin{tabular}{c|c|c|c}
\hline \hline Temperature, & Zea Mats. & Ertum lexs. & $\begin{array}{c}\text { Phaseolus } \\
\text { MULTIFLorus. }\end{array}$ \\
\hline $50.0^{\circ}$ & - & - & - \\
40.0 & - & - & - \\
37.5 &,-+ & - & - \\
35.0 & + & - & - \\
30.0 & + & - & - \\
27.5 & + &,-+ & - \\
25.0 & + & + &,-+ \\
22.5 & + & + & + \\
20.0 & + & + & + \\
15.0 & + & + & + \\
\hline
\end{tabular}


This table shows that the sense of thermotropism is not constant for all temperatures, but is positive at the lower temperatures, negative at the higher ones, and neutral at a certain intermediate one. Also, just as different species vary in their optimum so also do they vary in the temperature of neutrality. As the optimum for growth is high in maize radicles $\left(34^{\circ}\right)$, and low in the pea radicle $\left(26^{\circ} .3\right)$, so also is the neutral point. The neutral temperature is thus also probably related to the attunement of the organism and is an advantageous response.

Within the range of positive or of negative turning there is a correlation between the temperature and the angle of inclination of the organ. KLERCKER has paid par-

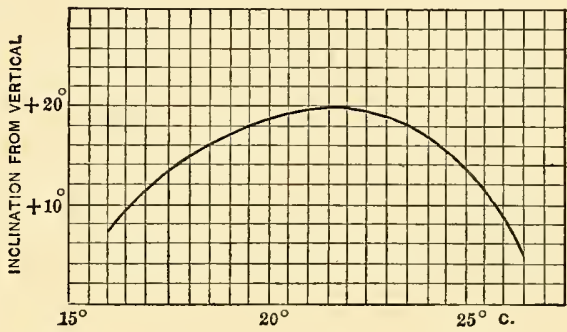

FIg. 133. - Caloritropic curve of Sinapis alba, showing the relation between the inclination of the radicle and the surrounding temperature. The numbers on the left give the inclination in degrees; the horizontal series of numbers are the temperatures to which the plant is subjected, the temperature diminishing $4^{\circ}$ for every centimeter of departure from the source of heat. (After AF KLERCKER, '91.)

ticular attention to this fact. His results are summarized in the following table and curves, showing for each species the average inclination at each range of temperature :-

\section{TABLE LVI}

The Sense ( + or - ) and the Average Extent (expressed in Degrees of Angular Deviation from Verticality) of Thermotropism at DifferENT TEMPERATURES

Pisum sativum

Sinapis alba $|+10.5 \quad|+19.0 \quad|+2.4 \quad|$

$$
|-8.9|-12.9|-27.2|-38.4|-43.9|
$$

\begin{tabular}{l|l|l|l|l|l|} 
Faba vulgaris & -4.3 & -6.5 & -9.8 & -19.1 & -28.9
\end{tabular}

${ }^{\circ}$ C. . . . $13,14,15,16,17,18,19,20,21,22,23,24,25,26,27,28,29,30,31,32,33,34,35,36,37,38,39,40,41$

We see here that the angle of inclination (whether + or - ) increases regularly as we depart from the temperature of neutrality or that of $0^{\circ}$ curvature. 
3. Causes of Thermotropism. - VAN Tieghex suggested, in his a priori account of thermotropism, that it was due to an unequal growth on the two unequally heated sides of the organ, the side whose temperature was nearest the optimum making the greater growth. This explanation is not a direct mechanical one, the turning stem does not act merely like a metallic rod. The curvature is rather the result of unequal growth at unequal temperatures. In accordance with the theory just outlined we should find organs subjected on one side to the optimum temperature growing on that side faster than on the other, and hence turning from the optimum - but they turn towards it. Again, plants subjected on one side to a temperature slightly below the optimum will have a still lower temperature on the opposite side, and should be negatively thermotropic - but they are positive. Finally, plants subjected on one side to a temperature above the optimum will have a lower temperature, one nearer the optimum, on the opposite side, and should be positively thermotropic but they are negative. In a word, according to the theory, plants should turn from the optimum; they turn, however, towards the optimum, hence VAN TIEGHEM's theory is exactly opposed to the facts.

Wortmann, on the other hand, believed that the sense of thermotropism is due to a self-regulation of growth in the organism leading it to make this advantageous turning. The stem tends to place itself in the axis of the heat rays just as in phototropism it places itself in the axis of the rays of light. To this theory we must, however, add that plant organs may respond to conducted heat as well as to radiant heat, since they turn in a direction which, although opposed to the ordinary law of growth, tends to bring the tip into its optimum temperature. Such a result indicates clearly that thermotropism is a response to stimulus.

If thermotropism is a response, where is the perceptive region? Suspecting that it was at the apex, Wortmann decapitated the root tip, but the response occurred as before. Evidently the whole growing part is sensitive to temperature.

Thermotropism is thus seen to be such a response to the stimulus of either radiant or conducted heat that the organ-plumule, 
radicle, flower-bud or sporangiferous hypha - tends to place itself in the axis of the heat rays, if there are any, or to bend towards or from the source of heat. Whether the organ shall bend towards or from the source of heat depends both upon the external temperature and the protoplasm of the plant. The turning is such that it will tend to keep the organ at the optimum temperature for its protoplasm, or bring it into such a temperature. The response is thus, on the whole, an advantageous one.

\section{Summary of the Chapter}

There is in all organisms a close relation between temperature and rate of growth, such that growth is most rapid at that temperature at which the ehemical changes of metabolism proceed most quickly. "The position of this optimum varies with the normal thermal environment of the race; it is attumed, we may say, to that normal temperature. Certain organisms or their parts grow in a definite direction with reference to the source of heat: away from the source when its temperature is too high; towards the source when the temperature is low. The neutral point varies in the different species in much the same way as the optimum for growth varies. We may say that the different attunements of organisms determine their different neutral points. At the same time these responses are advantageous. In some way the advantageous response of the organism is bound up with its attunement.

\section{LITERATURE}

Askenasy, E. '90. Ueber einige Beziehungen zwischen Wachsthum und Temperatur. Ber. deut. Bot. Ges. VIII, 61-94. 23 April, 1890.

Barthéleny, A. '84. De l'action de ia chaleur sur les phénomènes de végétation. Comp. Rend. CXVIII, 1006, 1007. 21 April, 1884.

Bialonlocki, J. '71. Ueber den Einfluss der Bodenwärme auf die Entwicklung einiger Culturpflanzen. Landw. Versuchs-Stat. XIII, 424-472.

Copeland, E. B. '96. Ueber den Einfluss von Licht und Temperatur auf den 'Turgor. Inaug. Diss., 59 pp. Halle. Bot. Centralb. LXVIII, 177-180. 4 Nov. 1896.

Cuenot, L. '94. L’influence du milieu sur les animaux. Encyclopédie scientifique des Aide-Mémoire. Paris : [1894]. 
EARLL, R. E. '80. A Report on the IIistory and Present Condition of the Shore Cod-fisheries of Cape Am, Mass., etc. Rept. U. S. Fish Com. for $1878.685-740$.

EIDAM, E. '75. Untersuchungen über Bacterien, III. Beiträge zur Biologie der Bacterien. 1. Die Einwirkung verschiedener Temperaturen und des Eintrocknens auf die Entwicklung von Bacterium Termo, Duj. Beitriage z. Biol. d. Pflanzen. I, 208-224.

FÉRÉ, C. '94. Note sur l'influence de la température sur l'incubation de l'œuf de poule. Jour. de l'Anat. et de la Physiol. XXX, 352-365.

Fiscuer, A. '97. Vorlesungen über Bakterien. Jena: Fischer, 1897.

Forster, J. '87. Ueber einige Eigenschaften leuchtender Bakterien. Centralb. f. Bacteriol. u. Parasitenk. II, 337-340.

Herrick, F. H. '96. The American Lobster. Buil. U.S. Fish.Com. XV, 1-252. 64 plates.

Hertwig, O. '96. Ueber den Einfluss verschiedener Temperaturen auf die Entwicklung der Froscheier. Sitzungsb. Berlin Akad. Jan. 1896. 105-108. 6 Feb. 1896.

'98. Ueber den Einfluss der Temperatur auf die Entwicklung von Rana fusca und Rana esculenta. Arch.f. mik. Anat. LI, 319-381. S Jan. 1898.

Higgenвotton, J. '50. (See Chapter XVII, Literature.)

Krrchner, O. '83. Ueber das Längenwachsthum von Pflanzenorganen bei niederen Temperaturen. Beiträge z. Biol. d. Pflanzen. III, 335-364.

KLercker, John af, '91. Ueber caloritropische Erscheinungen bei einigen Keimwurzeln. Öfversigt af Kongl. Vetenskaps. Akad. Förh. XLVIII, $765-790$.

Köppen, W. '71. Waerme und Pflanzenwachsthum. Bull. Soc. Impér. des Naturalists, Moscow. XLIII, Part 2, 41-110.

Lillie, F. R., and Knowlton, F. P. '97. On the Effect of Temperature on the Development of Animals. Zoölogical Bulletin. I, 179-193. Dec. 1897.

Meyer, H. A. 78. Beobachtungen über das Wachsthum des Herings im westlichen Theile der Ostsee. Jahresber. der Commission zur wiss. Unters. d. Deutschen Meere in Kiel. IV-VI, 227-251.

Rauber, A. '84. Ueber den Einfluss der Temperatur, des atmosphärischen Drucks und verschiedener Stoffe anf die Entwicklung thierischer Eier. Sb. Naturf. Ges. Leipzig. X. 55-70.

RICE, H. J. '84. Experiments upon Retarding the Development of Eggs of the Shad, made during 1879 , at the U. S. Shad Hatching Station at Havre de Grace, Md. Report U. S. Fish Com. for 1881. 787-794.

SAcrs, J. '60. Physiologische Untersuchungen iiber die Abhängigkeit der Keimung von der Temperatur. Jahrb. f. wiss. Bot. II, 338-377.

Schultze, O. '94. Ueber die Einwirkung niederer Temperatur auf die Entwicklung des Frosches. Anat. Anz. X, 291-294. 19 Dec. 1894.

SEMPER, C. '81. Animal Life as affected by the Natural Conditions of Existence. 472 pp. New York, 1881.

Tieghem, P. van, '82. Traité de Botanique. Paris, 1884. [First part issued in 1882.] 
True, R. H. '95. On the Influence of Sudden Changes of Turgor and of Temperature on Growth. Ann. of Bot. IX, 365-402.

Vernon, H. M. '95. (See Chapter XVII, Literature.)

V̈̈снтілG, H. 's8. Ueber den Einfluss der strahlenden Wärme auf die Bluthenentfaltung der Magnolia. Ber. deut. Bot. Ges. VI, 167-178.

Vries, H. DE, '70. Matériaux pour la comnaissance de l'influence de la température sur les plantes. Arch. Néerlandais. V, 385-401.

Ward, H. M. '95. (See Chapter XVII, Literature.)

Wiesner, J. 73. Untersuchungen äber den Einfluss der Temperatur auf die Entwicklung des Penicillium glancum. Sb. Wien. Akad. LXVIII', $5-16$.

Wortuans, J. '83. Ueber den Einfluss der strahlenden Wärme auf wachsende Pflanzentheile. XLI, 457-470, 473-479. July, 1883.

'85. Ueber den Thermotropismus der Wurzeln. Bot. Ztg. XLIII, 193 et seq. 


\section{CHAPTER XIX}

EFFECT OF COMPLEX AGENTS UPON GROWTH, AND GENERAL CONCLUSIONS

Is the foregoing chapters we have examined the effect upon growth of various agents considered as acting separately. This treatment has been necessary for purposes of analysis, but it has the disadvantage that it does not reveal the normal action of these agents. For, in nature, we find many agents working together upon the growing organism. For example, gravity is constantly acting in one direction, upon sessile organisms at least, and at the same time the chemical character and the density of the surrounding medium, contact and impact, light and heat, are exerting their specific influences. The rate of growth of an organism and the direction of growth of its organs are determined by the resultant of some half dozen controlling factors which, in their totality, constitute environment.

Again, some of the factors inflnencing growth are so complex that they are not yet amenable to analysis into the chemical, molar, and physical agents whose effects we have considered in foregoing chapters. For instance, the reaction of an organism to its own activity is still too complex an effect for us to be able to resolve it into its elemental reactions to pressure, chemical change, etc. The effect of exercise upon growth may consequently form a subject for special consideration.

\section{§. The Coöperation of Geotropism and Phototropism}

When light falls from one side upon a seedling in the ground, the seedling is influenced by both gravity and light, and tends to respond to both. In responding to both, the apex of the seedling tends to point upwards on account of gravity's action, and laterally towards the source of illumination on account of 
the light. As a result of this combined response the plant comes to occupy an oblique position.

The exact angle assumed by the plant is variable. It varies in a given species with the intensity of the light, and, the intensity of the light remaining constant, the angle varies with the species. For example, seedlings of Lepidium sativum subjected to a unilateral horizontal illumination for 48 hours showed at different intensities of the light the following inclinations from the vertical (WIESNER, '79, p. 196):-

Distance of Seeding from Flane.

0.25 meter

0.30 "

0.75 " 6

1.25 "

2.50 " (optimum)

3.00 "

3.75 "
INCLINATION FROM VERTICALITT.

$30^{\circ}$

35

55

70

80

65

35

This table shows that the inclination from verticality inereases with the intensity of illumination to a certain maximum degree, beyond which it diminishes again. This maximum inclination is called the phototropic limiting angle.

More extended determinations of the limiting angle have been made by CzApEK ('95), who finds that it is the same for a given intensity of horizontal light whether the plant is vertical or horizontal, having its apex directed towards the source of light.

\section{TABLE LVII}

Giving the Phototropic Limitixg Angle for Various Species of Plants

Phycomyces nitens . . $90^{\circ}$

Pilobolus erystallinus . . 90

Vicia sativa. . . . . 70

Avena sativa . . . . 70

Phalaris canariensis . . . 70

Linum usitatissimum . . 70

Brassica napus . . . . . 70

Datura stramonium . . . 70

Lepidium sativum . . . 60
Sinapus alba (plumule) . . $60^{\circ}$ Pisum sativum . . . . 60

Vicia faba . . . . . 60

Phaseolus multiflorus . . 60

Sinapis alba (radicle) . . 50

Helianthus annus . . . . 45

Ricinus communis . . . 45

Cucurbita pepo. . . . . 40 
The phototropic limiting angle is constant for all cases in which gravity and light act at a right angle, whether the plant axis be originally placed vertically upright, inverted, or horizontal. When the direction of the light ray makes some other angle with that of gravity, the resulting position of the plant may be quite different, as CzAPEK ('95) has shown.

If the light falls upon the plant vertically from below, in such a way therefore as directly to oppose gravity, the resulting position of the plant varies according to its original position, in a way generally explicable on the ground that one of the two tropic influences has come to prevail, but with diminished power. Thus, when the axis of the seedling is horizontal it will, if like Avena it is very sensitive to light, turn its tip slightly upwards for a time, and then definitely down. A slightly phototropic plant, like Helianthus, assumes its limiting angle of $45^{\circ}$ from the zenith. When the seedling is exactly inverted, plants highly sensitive to light grow down, but Helianthus places itself at $135^{\circ}$ from the zenith, hence no longer at the limiting angle. When the axis of Helianthus is placed obliquely downwards its tip becomes inclined at $45^{\circ}$ from the zenith.

If the ray of light falls upon the plant obliquely from below, the result on the erect, horizontal, or inverted seedling is a response to the active component of the light ray. The erect seedling is affected in the same way as by the horizontal ray; the horizontal seedling responds as though the light came vertically from below, and all inverted plants place themselves in the axis of the infalling ray.

If the ray of light falls obliquely from above, all plants, even Helianthus, place themselves in the axis of the ray. This is what might have been anticipated, since gravity affects the inclined plant much less than the horizontal one, and so the active component of the light ray is relatively more effective in this oblique position than in the horizontal one.

The foregoing experiments show that, in general, the geotropic reaction is modified by the simultaneous action of light. I have hitherto assumed that the final position of the plant is the resultant of the action of two tropic agents ; that the phototropic and geotropic reactions interlock. Another cause of 
the modified position is, however, possible. The stimulating action of light may interfere with the sensibility of the plant to gravity. An early experiment made by CzAPEK seemed to indicate that this is the case. A vertical plant was illumined upon one side and then placed horizontally with the former illumined side facing the nadir. The geotropic curvature was, as might be inferred from the experiment described on p. 444, greatly retarded. The retardation of geotropism by a previous photic stimulation occurs, however, only in species which are much more phototropic than geotropic. That the result just described is not due to a diminution in geotropic sensitiveness follows from two considerations: first, a plant previously geotropically stimulated is not retarded in its subsequent phototropic response, as we should expect if the irritated state interfered with the reception of a new stimulus; secondly, the retardation in response to light after geotropic stimulation is most directly explained on the ground that a response which is being actually worked out interferes with an incipient response.

The conclusion may, consequently, be drawn that there is no reason for believing that the modified response resulting either from the simultaneous or successive action of two tropic agents is due to an alternation of geotropic or phototropic sensitiveness, but rather to a modification of the response. The modification of the response is due to the interlocking effect or the mutual interference of the phototropic and geotropic reactions to stimuli.

\section{§ 2. Effect of Extent of Mediun on Size}

The quantity to which an organism shall grow - the size that it shall attain - is a specific character which is, within limits, independent of the amount of food consumed by the organism. In how far this character is dependent upon other environmental conditions is an interesting question. It is clear that size is relative, and among other things it is related to the extent of the space in which the organism can move. An ant can lose its way in a cage in which an elephant can hardly find room to move. The ant is small, the elephant large, in relation to their common room. 
Now it is a common observation of naturalists that there is frequently a relation between the size attained by a developing organism and the extent of the medium in which it is developing. Animals reared in aquaria rarely attain the size of their fellows developing in out-of-door ponds. Even in nature, fishes of a given species living in small or densely inhabited ponds are smaller than fishes of the same species inhabiting large or sparsely populated ponds. According to SEMPER ('74) the experiment was tried of transplanting the very small chars from a small lake in the Maltathal, Carinthia, Austria, where they were very abundant, to another lake where there were few fish. The transplanted chars soon became three times the size of the parent stock.

In other experiments it has often been observed that tadpoles. reared in the laboratory, although well fed, never attain the size of those living free. SIEBoLD $*$ found that Apus reared in a small vessel grew no longer than 7 or $8 \mathrm{~mm}$. instead of 50 or more. The pond-snail, Limnea stagnalis, has been made the special object of experimental dwarfing. HogG ('54) found that when confined to a small, narrow cell they acquire, even after six months, only the size of normal animals two or three weeks old. HoGG's conclusions no doubt appeared crude to the physiologist of the last decade. He said that the snail grows "to such a size only as will enable it to move about freely, thus adapting itself to the necessities of its existence."

SEMPER ('74) next undertook a more thorough set of experiments upon these animals. He kept the snails in vessels containing different quantities of water to each individual, and found that as the quantity of water is diminished from $4000 \mathrm{cc}$. or 2000 cc. to $100 \mathrm{cc}$, a diminution in the rate of growth occurs. Increasing the number of individuals in a vessel has the same effect as diminishing the volume of water. The relation of volume of water per individual to length of shell at the end of eight or nine weeks is given in Fig. 134. This curve shows that as the volume increases from $100 \mathrm{cc}$. to $800 \mathrm{cc.}$, the average length of the shell of the snail doubles. The result SEmper 
explains on the hypothesis that water contains some substance necessary to the growth of the snails, which becomes used up before full size is acquired: the more quickly, of course, the smaller the amount of water.

Instigated by SEMPER's experiments YUNG ('85) now undertook similar ones upon tadpoles. Twenty-five just-hatched tadpoles were put into each of three vessels, A, B, and C, containing about $1200 \mathrm{cc}$. of water, but of different forms, so that $A$, which measured $7 \mathrm{~cm}$. diameter, had a depth of $30 \mathrm{~cm}$. of water ;

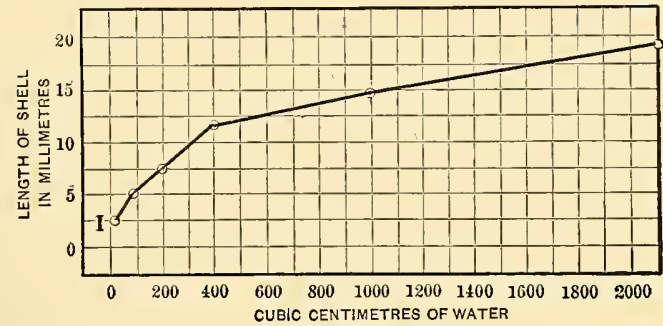

Fig. 134.-Curve of relation between length of shell of Limnæa stagnalis and . quantity of water in which it is reared. (From SEmper, '74.)

B, whose diameter was $11 \mathrm{~cm}$., had $13 \mathrm{~cm}$. of water; and C, whose diameter was $14.5 \mathrm{~cm}$., had $6.5 \mathrm{~cm}$. of water. At the end of one and a half months measurements were made of the length and the breadth of each tadpole with the following average results :-

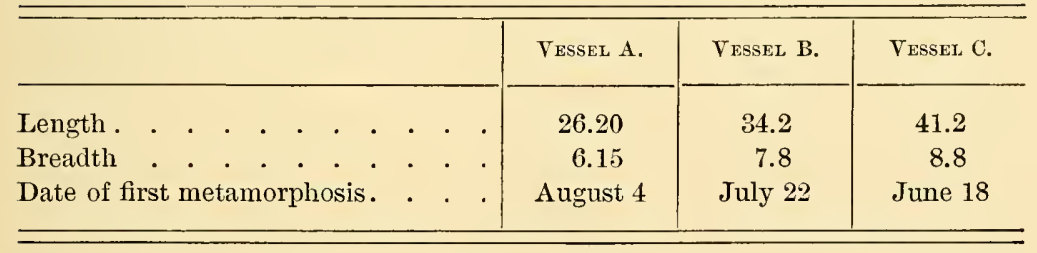

YUNG concluded that the larger size of the animals in the shallower water (C) was due to its absorbing oxygen more thoroughly.

Finally, DE VARIGNY ('94) has attacked even more systematically this problem of effect of extent of medium on size. He has found that Limnæas kept for eight months in similar vessels, each containing $550 \mathrm{cc}$. of water and about $500 \mathrm{cc}$. of 
air, but differing in that one was stoppered and the other not, had attained about the same size (Fig. 135). Since the oxygen supply of the snails in the two vessels was evidently very dissimilar, YUNG's explanation is shown to be inadequate. Next DE VARIGNy tested the effect of differences in volume. $\mathrm{He}$ reared Limnæas in different quantities of water, in vessels of dissimilar proportions, such that in all there was the same free surface area of water. The differences in volume had only a slight effect on the size of the snails (Fig. 136). On the other hand differences in surface, with constant volume of water, have an important influence on size. The greatest growth occurs in the broader vessel (Figs. 137, 138). The number of individuals in the vessel influences the average size, as SEMPER found.

To test Semper's theory that the small size of the animals in the small vessel is due to its having exhausted the necessary substance in the water, DE VARIGNY partitioned a vessel of water into two unequal compartments and reared a Lymnea in each. One of the compartments was made by partly submerging a test-tube, from which the bottom had been removed, in a beaker of water. A piece of muslin, tied over the bottom of the test-tube, permitted an interchange of water, but not the intermigration of the Limnæas between the test-tube and the main vessel of water. The latter constitutes the second compartment in which the snails lived. After several months the individuals kept in the two vessels usually showed a marked difference in size, those reared in the roomier vessel being the larger (Fig. 139). When, however, the two similar snails were kept in similar tubes plunged in beakers of water of unequal volume, they attained about the same size.

A second test of Semper's theory applied by DE VARIgny consisted in comparing the growth of Limnras in fresh water with their growth in water in which snails had for some time been developing. The snails in the latter showed a slight but nearly constant inferiority in size. It may well be that some of the salts necessary to growth had been extracted from the water by the development of snails therein, making it less fit for growth. Nevertheless, even the most marked differences in the size of the snails in the two kinds of water was not sufficient fully to account for SEMPER's result by means of SEMPER's theory. 
FIG. 135. - Two individuals of Limnæa stagnalis, which have lived from May, 1891, to January, 1892, in two flasks nearly alike in respect to surface and volume of water. In the one case (shell at left) the flask, enclosing 500 cc. of air, was sealed; in the other case (shell at right) the flask remained unsealed throughout the 8 months of experimentation. (From de Varigny, '94.)

FIG. 136. - Limnæa auricularis, reared in different masses of water having the same surfaces but different volumes. The specimens, taken in order from left to right, were reared in vessels having surface areas of $100,200,400$, and 500 cc. respectively. Experiments exteuded from 15 November to 5 April. (From DE VARIGNY, '94.)

FIG. 137. - Limnæa stagnalis. The individual at the left lived from 18 November to 20 April in a liter of water having a surface of only $2 \mathrm{~cm}$.diameter; that at the right lived during the same period in an equal volume of water having a surface of $18 \mathrm{~cm}$. diameter. (From DE VARIGNY, '94.)

FIG. 138. - The Limnæa stagnalis at the left lived from 21 November to 6 January in 1350 cc. of water having a surface of $3.5 \mathrm{~cm}$. diameter; that at the left, somewhat larger,
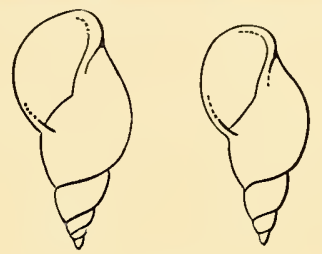

135
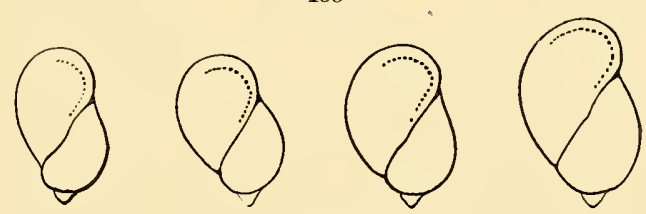

136
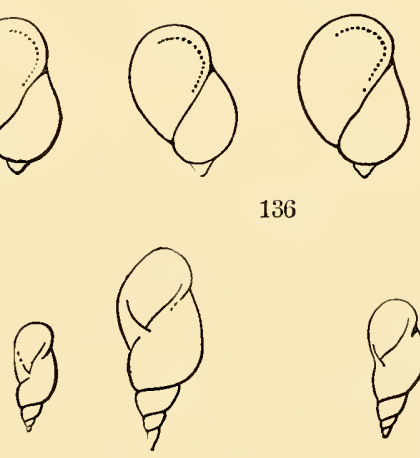

137
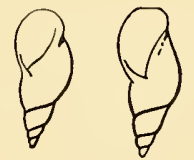

138

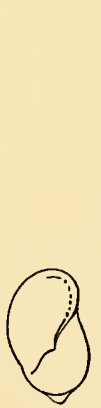

1
2

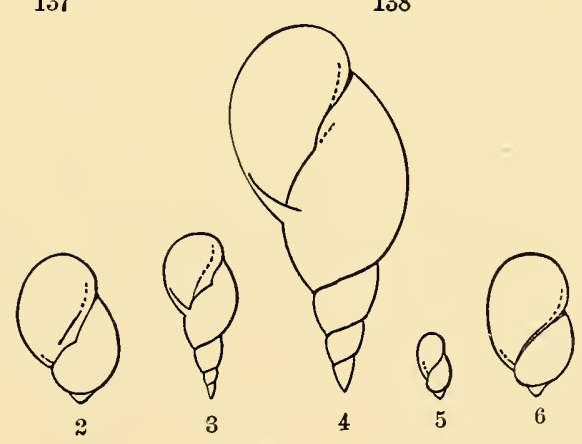

139

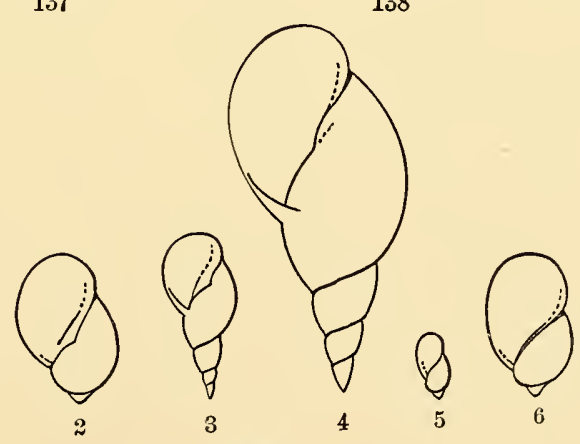
lived during this period in $600 \mathrm{cc}$. of water having a surface of $16 \mathrm{~cm}$. diameter. (From DE VARIGNY, '94.)

Fig. 139. - Limnæa 1 lived from 18 November to 5 April in a glass without a bottom (capacity $250 \mathrm{cc}$.), suspended in the beaker (capacity $4200 \mathrm{cc}$.), in which 2 lived. Limnea 3 lived from 20 November to 7 February in a tube, suspended in a vessel in which 4 was reared. Limnæa 5 lived from 9 April to 24 June in a tube, suspended in the vessel in which 6 lived. (From DE VARIGNy, '94.) 
The conclusion to which DE VARIGNY arrived was that the nanism provoked in the suall vessels is caused by a diminution of movement and consequently of exercise, for in the restricted medium the movements are fewer and slighter, since the food is near at hand. Also, the snails will exercise more in a body of water with a broad, exposed surface than in a narrower one, because they crawl so much on the surface films.

This interpretation is sustained by all the results excepting those obtained from a varying number of individuals in masses of water of the same volume and form. The fact that the individuals grow larger the fewer they are, may be accounted for, thinks DE VARIGNY, on psychological grounds; for, in the erowded room, movements will be restricted from very much the same cause that makes one move less rapidly in a street containing impediments than in one which is quite clear.

It may well be doubted whether the bottom of this matter has yet been reached. Probably nanism is produced by several causes : such as insufficient supply of mineral constituents in the water, especially of calcium salts, products of excretion in the water, and exercise. There is, however, much reason for believing that HogG's conclusion is one which, with our fuller knowledge, we can hardly improve upon - that, in respect to the size attained as in other qualities, the snail has the power of "adapting itself to the necessities of its existence."

\section{§ 3. General Consmerations relating to the Action upon Growth of External Agents}

1. Modification of Rate of Growth. - Protoplasm is composed of three kinds of substances: the living plasma, the formed substance, and the watery chylema. Accordingly, growth involves three processes : that of the formation of new plasms, assimilation; that of the manufacture of formed substance, secretion; and that of the absorption of water, imbibition. Anything which affects these three processes will affect the rate of growth.

The action of external agents upon the rate of growth is of two general kinds. There is, first, the general effect; and, secondly, the specific effect. The general effect is more or less similar in all protoplasmic masses (organisms) subjected to the agent; it is the result of some immediate and necessary modifi- 
cation of the protoplasm depending upon its very structure. This general effect may be of two sorts : a grosser mechanical one and a more refined. The grosser general effect is seen in the osmotic action of dense solutions; in the elongation of an organ consequent upon pulling it with a considerable force; in the interference with vital actions by poisons, by intense light, or by high temperatures. The more refined general effect is due to the acceleration of growth by the acceleration of the essential metabolic processes involved in growth; hence come the effects, within limits, of favorable foods, of electricity, of radiant energy, and of warmth. We can explain the effect of such refined agents by known chemical laws.

The grosser and the finer effects pass over into each other at certain intensities. Thus the acceleration of growth produced by summer temperature passes over at a higher temperature into the gross retardation due to coagulation.

The specific effects, in contradistinction to the general, appear only in certain organisms or their parts, and have no such evident and explicable relation to the cause as the general effects have to their causes. Such is the increased growth resulting from certain slight poisons, from the deformations of the stems of certain plants, from a wound which leaves a defect to be filled by growth. These effects cannot at present be accounted for satisfactorily by known chemical processes; they result from peculiarities of the specific protoplasms which depend largely upon the past history of each kind of protoplasm.

The same agent may have at different intensities, at one time, the specific; at another, the general effect. Thus the slight pulling of the stem of a seedling may induce the specific shortening effect, whereas a stronger pull will cause a gross elongation.

The gross general effect, the refined general effect, and the specific effect form a series of results brought about by processes which are quite intelligible in the first case, much more complex in the second, and still further removed from our ken in the last; we might speak roughly of these efiects as due to physical, chemical, and vital processes respectively, without meaning to imply a qualitative difference between these processes. The most complex of these three processes may also be designated as response to stimulus. 
Let us now consider the mechanics of the acceleration of growth by various agents. The mechanics of the effect of food on growth varies of course with the food; some supplying the energy or the material for assimilation, other kinds furthering secretion, and still others going to build up the molecules which do the work of vital imbibition. Whether the poisons which, like zine sulphate, stimulate growth affect chiefly the assimilatory or the imbibitory process, is unknown; but the slowness of the result suggests a modification of assimilation. The effects of water and of solutions seem to be chiefly upon imbibition; that of deformation and wounding chiefly upon assimilation; that of electricity is uncertain; that of light is probably chiefly upon assimilation; and that of heat upon imbibition. These conclusions are, however, tentative; experiments are needed to test them further : this is one of the next tasks in the investigation of growth.

2. Modification of Direction of Growth - Tropism. - The tropic effect of an external agent occurs only when the agent does not act uniformly from all sides upon the growing organism, but constantly from one side. Hence this effect will be marked only in organisms which for a considerable period present the same surface to the action of the agent. Such an effect is characteristic therefore of sessile plants and animals.

The turning of an organ with reference to an external agent may be either a gross effect or a specific response effect of the agent. As examples of the gross effect may be cited the cases of false traumatropism and false electrotropism, in which the turning is due to the death or injury of the tissue on the concave side of the organ. All cases of true tropism are cases of response to stimuli: such are, chemotropism, hydrotropism, thigmotropism, traumatropism, rheotropism, geotropism, electrotropism, phototropism, and thermotropism.

The mechanics of these tropic responses may now be briefly considered. In general the tropisms are growth phenomena, for they are due to enlargement of the bending organ on one side. The growth seems to be due either to assimilation or imbibition, or both, secretion playing no part. It is not easy. to say whether in any case assimilation or imbibition is the more important. An inference can be drawn, however, from 
the quickness of response, for growth by imbibition is more rapid than that by assimilation. Also a histological study of the curving region should throw light upon this question. Among the rapid tropisms are chemotropism, especially as seen in the tentacles of Drosera and in pollen-tubes, and thigmotropism, as exhibited in tendrils. Such are probably due to differential imbibition. Among slow tropisms are hydrotropism and rheotropism, which are probably due largely to differential assimilation. Traumatropism, geotropism, and the response to radiant energy, namely, electrotropism, thermotropism, and phototropism, are intermediate in their rate, and are probably due to the combined action of assimilation and imbibition.

Sections through the responding region shor the importance of imbibition in certain tropisms, as, for example, geotropism. In such sections it is seen that the cells on the convex side are enlarged in all axes and full of water, while those of the concave side are compressed so that the cells are shoved into one another, are diminished in size, and have a dense plasma (Fig.140). A typical set of measurements

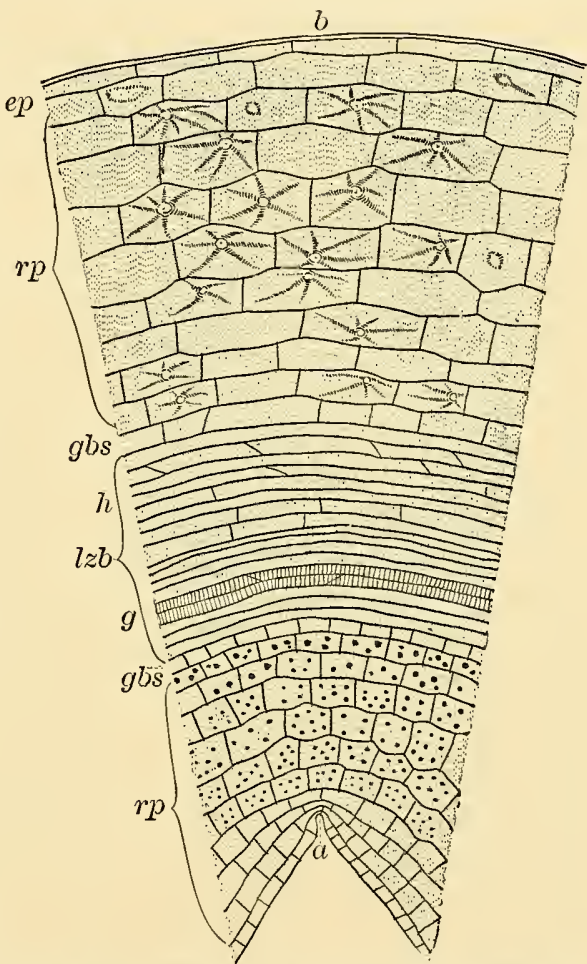

FIG. 140. - A section of a tropic radicle taken in the plane of curvature, at the region $s g$, Fig. 106. ep, epidermis ; $r p$, parenchyma; $g b s$, sheath of the fibro-vascular bundle; $l z b$, fibrovascular bundle; $h$, wood-cells; $g$, ressels. Those cells which lie next the nadir (a) are smaller than those turned toward the zenith (b). The latter appear stretched with water, while the former are dense and of small size. (From Ciesielski, '72.) of the dimension of the cells in the curving region, compared with normal cells, is given by Ciesielski ('72) as follows :- 


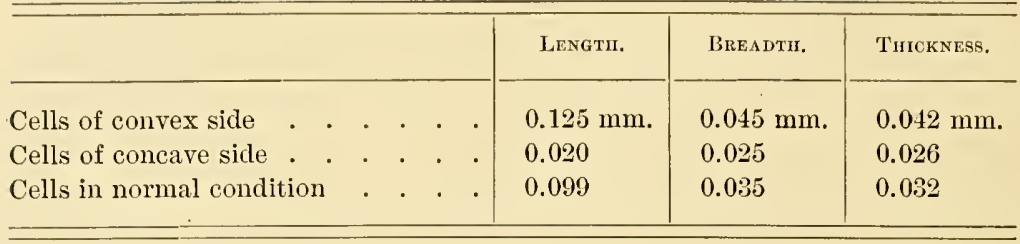

The importance of imbibition for geotropism is also shown by the experiment of cutting a slice off from the upper part of the horizontal root, which then curves only slowly; whereas, if the cut surface is placed down, the curving takes place with abnormal rapidity.

It being admitted that tropisms are, for the most part, largely, if not chiefly, due to differential imbibition, the question arises, How can this produce a turning? It is easy to see how it might be possible in the case of a multicellular plant, but tropism also occurs in animals and unicellular organs, as e.g. the hyphr of Mucor. It has been suggested, to meet this difficulty, that the unequal growth affects primarily the cellwalls; but this explanation does not quite meet the case of hydroids. A general statement, applicable to multicellular plants and animals and to unicellular organs, may be made, if the cell-wall be recognized as living, as follows: The imbibition distends the living substance on the convex side, the water probably being in part drawn from the concave side.

Going a step farther, the tropic agent produces such a change in the molecules of the curving region as to cause them to imbibe water with abnormal rapidity. This change may, however, be produced by the agent either directly or indirectly. In all cases in which the sensitive part of the organ becomes the curving part, the action of the agent is direct. Examples are found in the thigmotropism of tendrils, in the phototropism and thigmotropism of stems, and, probably, in traumatropism. In cases in which the curving part is remote from the sensitive part, as in geotropism, the action of the agent is indirect. In these cases there must be a transmission of a stimulus from the sensitive part (the tip) to the responding part, producing the required molecular change there.

Concerning the nature of the changes induced by the tropi- 
cally stimulating agent, we have recently gained valuable data from the studies of CzAPEK ('98). He has found that the stimulated protoplasm, for instance, of a geotropic radicle exhibits no visible movements or negative electrical variation, as in the nerve cells of animals, but does exhibit a chemical change. Thus, when the root tip of the seedling of a bean or other species is boiled in a solution of ammoniacal silver nitrate, there is a marked reduction of the silver, especially in the cells of the periblem. This reduction is stronger in the cells of stimulated root tips than in those of unstimulated ones. A second change consists in the diminution in the amount of a substance of the root tip which easily loses oxygen. Such a substance is indicated by such changes as these in the normal root tip: blue coloration (oxidation) of a section of the tip when placed in an emulsion of guaiac gum in water; deep blue coloration of sections by indigo white*; strong violet reaction (indophenal reaction) in sections sub. jected to an aqueous solution of a-naphthol to which paraphenylendiamin has been added. Now all such reactions are less marked in the root after stimulation. We conclude that stimulation results in increased capacity for reduction and diminished capacity for oxidation — an increase in the avidity for oxygen.

These changes occur long before the response of turning shows itself; they occur earlier in the non-sensitive roots, and they are less marked after a slight stimulus, such as results from a slight inclination of the root from the vertical position.

The isolation of the two substances, the reducing and the oxidizing, was now attempted. The former is not changed by boiling or by the action of chloroform, and is soluble in alcohol; the latter is destroyed by heat, is unchanged by chloroform, is insoluble in alcohol, and may be extracted from the triturated cells by water. A large number of root tips of Vicia faba were rubbed up with water until no fragments remained. This aqueous extract was filtered, and to the filtrate alcohol was added. A precipitate occurred, which had all the properties of the oxidizing substance. It is highly probable that it belongs to the category of oxidation ferments.

* This is made by the cautious reduction of indigo carmine by dilute hydrochloric acid and zinc. 
To get the reducing substance, the preceding solution was filtered to eliminate the alcoholic precipitate. The filtrate had all of the qualities of the reducing substance. A further study of its properties indicated that it belongs to the aromatic organic substances, many of which have an intense reducing action and are hence used in photography.

We may conclude that geotropic stimulation of the root tip induces chemical changes leading to the increase of a reducing substance of aromatic nature, and to the diminution in amount of an oxidizing ferment.

3. Adaptation in Tropisms. - The capacity for bending is usually associated with an advantage accruing to the part by that bending. Thus, the upward tropism of the stem and the downward tropism of the root; the positive phototropism of the stem and the positive thigmotropism of the root and of the climbing Dodder; negative traumatropism; and positive and negative thermotropism, depending upon whether the source of heat is of a less or greater temperature than the optimum - all these responses tend to preserve the normal environment for the organism; they are adaptive. At least one tropic response cannot be shown to be advantageous, namely, electrotropism. Electric currents of such intensity as roots respond to certainly do not exist in the soil. The response has no conceivable advantage in the ordinary life of the plant, and yet it occurs with as much precision as does a response to light or heat. If only there were, in the ground, such electric currents as we apply to the plant, we might be able to show an advantage of the response in this case also!

4. Critical Points in Tropism. - It has been shown repeatedly in the foregoing chapters that the sense of tropism depends upon the degree of the stimulating agent. Thus Mucor stolonifer is strongly positively chemotropic with reference to $2 \%$ cane sugar; becomes less so as the concentration approaches $30 \%$; and is negatively chemotropic to a $50 \%$ solution. So, likewise, the radicle of Zea mais is

$$
\begin{aligned}
& + \text { thermotropic at } 12^{\circ}-36^{\circ} \\
& \pm \text { thermotropic at } 37^{\circ}-38^{\circ} \\
& \text { - thermotropic at } 40^{\circ}-49^{\circ} \text {. }
\end{aligned}
$$

In these cases, as in the tactic phenomena, there is recognizable an optimum intensity of the agent, to which the organism is 
attuned, so that, if the intensity rises above that optimum, negative tropism will occur, and, if the intensity falls below that optimum, positive tropism may be expected. This optimum this intensity to which the organism is attuned - differs, however, in different species. Thus, according to Wortmann, as we have seen, the turning-point of the radicle is for-

\author{
Zea mais, $37^{\circ}$; \\ Ervum lens, $27^{\circ}$; \\ Phaseolus multiflorus, below $22^{\circ}$.
}

But why is the turning-point so different in different species, or why are species attuned to different intensities? This difference is for the most part more or less closely correlated with the usual intensity of the agent to which the growing organism is subjected. To certain minds the phrase "Natural Selection" will be considered sufficient to stifle further inquiry; the known facts of self-adjustment, however, have thrown the burden of proof that Natural Selection has acted in any case upon those who assert it. Meanwhile we may seek for a cause more consistent with sound physiology.

In the first place, the facts of "after-effect" may be considered. It has been shown, with reference to the effect of many of the agents considered, that this effect does not endure only so long as the agent acts, but that it persists for a longer or shorter period after the stimulus has ceased to be applied. Thus, if a stem is placed horizontally, so that gravity stimulates it and causes it to grow up, and it is then placed vertically, the growth continues for a time in the former (now horizontal) direction; or, a horizontally placed root, decapitated after the lapse of one hour, curves geotropically, whereas a root placed horizontally and decapitated at once does not do so. Again, if a tendril is irritated by contact and the irritating body is then removed, a thigmotropic curvature of as much as $45^{\circ}$ may occur. Still again, in an experiment of DARWIN ('81, p. 463), a seedling of canary grass was placed before a window for nearly two hours, during which the cotyledon turned towards the glass; the light was now cut off, but the cotyledon continued to bend in the same direction for onefourth to one-half an hour. It was kept in the dark for an 
hour and forty mmutes (during which time it acquired an upright position through the action of gravity), and then exposed again to diffuse light from one side for an hour, showing the phototropic curvature. Light was now excluded, but the cotyledon continued to bend for 14 minutes towards the window. In these experiments there was a persistence of the response to light after light had been cut off. Finally, if a plant organ, which has been growing slowly at a low temperature, is quite rapidly subjected to the optimum, the increased growth is slow in making its appearance; it may be delayed for an hour or two.

What is the significance of this after-effect? It seems clearly to show that an agent acting on protoplasm not merely modifies the constitution of the protoplasm, but produces a change which is more or less permanent, and is only slowly obliterated upon removal of the agent, or becomes only slowly overshadowed by a new stimulus. This permanency of the change wrought permits the accumulation of extremely slight effects. An instance of such accumulation is seen in tendrils, which exhibit no response to a single soft blow but show evident thigmotropism to a series of such blows.

When, however, the repeated stimuli are each great, it is not an accumulation of effect which is noticed, but rather an absence of any response whatever. Then appears the phenomenon of acclimatization, or accustoming to the stimulus. Examples of this have been given in the foregoing chapters. Thus, in the case of thigmotropism, DARwIN found that after repeatedly stimulating the tendril of the passion flower (twenty-one times in 54 hours), it responded only slightly. In the case of traumatropism, DARwIN ('81, p. 193) observed that the radicle, to one side of which a card had been fixed by shellac, eventually became so accustomed to the stimulus that it no longer bent away from it, but grew vertically downwards. In the case of phototropism, WIESNER noticed that after a growing organ had been for some time subjected to daylight, its growth was less markedly controlled by a unilateral illumination.

Any general explanation of acclimatization, whether of metabolic or of growth processes, to repeated irritants must, at the 
present time, be hypothetical. The attempt to picture to ourselves the probable processes which bring about this condition should, nevertheless, be undertaken. It is generally accepted that a stimulus of any kind produces a chemical change in the protoplasm, and this leads to a change in the activity of the protoplasm - the response. The different kinds of stimuli usually induce different kinds of responses, and this is probably because each kind of stimulus affects a particular kind of molecule - a kind capable of being transformed by the stimulus in question. If we assume that the reception of any stimulus is due to the transformation of a specific kind of molecule capable of being acted upon by the stimtulus in question, then it is not difficult to see how, by repeated, violent stimulations of the same kind, nearly all of the molecules upon which sensation depends should become transformed, so that, thenceforth, the protoplasm should be incapable of receiving that kind of stimulus until such time as the sensitive substance shall have been reproduced. Let us imagine 100 molecules $\left(a_{1}, a_{2}, a_{3}, a_{4}\right.$ $\left.-a_{98}, a_{99}, a_{100}\right)$ in the root tips which are capable of being decomposed by daylight and as a result setting in motion a series of changes resulting in the phototropic response. Let us imagine that the irritation of light during the first half hour decomposes 50 of them ; during the second, 25 of the remainder; during the third, 12 of the remainder, and so on; then, eventually, the sensation will grow weaker if the substance is not renewed, so that the response will diminish in intensity and finally fail altogether. Then we say the organ is acclimated to the reagent, for the application of the agent produces no response.

This explanation of acclimatization to violent agents may now be easily extended to cover the case of attunement. Let us imagine a plant which, living in the dark, is negatively phototropic to ordinary daylight. It is attuned to a low intensity of light. If, however, the plant comes gradually to change its habitat so that it is repeatedly subjected to the sunlight, then, as a result of repeated stimulation, those sensitive molecules which are affected by the light are destroyed, so that the plant no longer turns from the light. It is attuned to it. The same theory, mutatis mutandis, will account for attunement to tem- 
perature or to chemical agents. It is to be observed that this hypothesis is not an hypothesis to account for response to stimuli ol of the usual adaptive nature of that response ; but to account only for that phase of "adaptation" which is seen in attunement. The hypothesis is an attempt to explain an adaptive result independently of selection, but rather as a necessary result of the constitution of protoplasm.

The adaptive acclimatized or attuned condition may be inherited. It has been shown that the acclimated condition may long persist, only eventually apparently disappearing. It may well be doubted, however, if the acclimated protoplasm ever returns exactly to its primitive condition. If it does not, progeny developed from the acclimated protoplasm will necessarily be different and respond differently from their parents. Individual attunement will initiate a race attunement.

\section{LITERATURE}

Ciesielski, '72. (See Chapter XIV, Literature.)

CzapeK, F. '95. Ueber Zusammenwirkung von Heliotropismus und Geotropismus. Sb. Wien. Akad. CIV1, 337-375.

'98. Ueber einen Befund an geotropisch gereizten Wurzeln. Ber. deut. Bot. Ges. XV, 516-520. Jan. 1898.

DARwin, C. and F. '81. (See Chapter XIV, Literature.)

HoGg, J. '54. Observations on the Development and Growth of the Watersnail (Limneus stagnalis). Trans. Micr. Soc. London. II, 91-103.

Semper, C. '74. Ueber die Wachsthums-Bedingungen des Lymnæus stagnalis. Arb. Zool.-Zoot. Inst. Würzburg. I, 13S-167.

VARIGNY, H. DE, '94. Recherches sur le nanisme expérimentale. Contribution à l'étude de l'influence du milieu sur les organismes. Jour. de l'Anat. et Physiol. XXX, 147-188.

Wiesner, J. '79. (See Chapter XVII, Literature.)

Yung, E. '85. (See Chapter XIII, Literature.) 


\section{LIST OF TABLES}

\section{IN PARTS I AND II}

TABLE NO.

I. Time of Resistance of Tadpoles to Varions Alcohols .

II. Time of Resistance of Infusoria and Ostracoda to Various Alcohols .

III. Time of Resistance Period of Spirogyra communis to Various Alcohols . . . . . . . . . 12

IV. Increase of Immunity resulting from feeding on Ricin . 29

V. Lethal Solutions of Gold Chloride for Various Bacteria . 46

VI. Relative Resistance Periods of Various Bacteria to Gold Chloride .

VII. Relative Resistance Period of Various Bacteria to Various Poisons . . . . . . . . . . 48

VIII. Percentage of Water in Organisms . . . . . $\quad . \quad 58$

IX. Resistance Periods of Fresh-water Crustacea to Various Constituents of Sea Salt . • • . . . . 81

X. Plasmolysis of Vorticella by Solutions . . . . $\quad$. 87

XI. Plasmolysis of Colpoda by Solutions . $\quad . \quad$. $\quad . \quad$. $\quad 87$

XII. Tonotaxis of Spirillum to Various Solutions . : $\quad$ - 91

XIII. List of Animals showing the Anex Type of Irritability $\quad 136$

XIV. List of Animals showing the Katex Type of Irritability $\quad 136$

$\mathrm{XV}$. Electrotactic Response of Various Invertebrates . . . . 147

XVI. Wave Lengths and Vibration Times of Different Parts of Spectrum . . . . . . . . . . . 155

XVII. List of Solutions giving nearly Monochromatic Colors $\quad$ • 157

XVIII. Phototactic Response of Various Animals . . . . 195

XIX. Results of Experiments to determine the Ultramaximum Temperature of Organisms in Water . . . . 234

XX. Determinations of the Ultraminimum of Organisms reared under Normal Conditions . . . . . . 244

XXI. List of Species found in Hot Springs, with the Conditions under which they occur. . . . . . . 250

XXII. Percentage of Water and Dry Substance in Frog Embryos at Various Ages . . . . . . . .

XXIII. The Percentage of Water in Chick Embryos at Various Stages up to Hatching . . . . . . .

XXIV. The Percentage of Water in the Human Embryo at Various Stages up to Birth . . . . . . . 286

XXV. Percentage Composition of Animals and Plants . . 295 
TABLF NO

XXVI. Percentage Composition of the Ash of Various Organisms

XXVII. Relative Abundance of Various Elements in the Ash of Organisms . . . . . . . . 297

XXVIII. Nutritive Solutions for Phanerogams . . . 301

XXIX. Inorganic Matters in Potable Water . . . . . . . 301

XXX. Nutritive Solntions for Algæ . . . . . . 302

XXXI. Nutritive Solutions for Fungi . . . . . . 302

XXXII. Conparison of Ash in New-born Dog and in the Milk of its Mother . . . . . . . . . 303

XXXIII. Results of feeding Tadpoles on Various Substances . . 329

XXXIV. Showing for Various Mammals the Time required to double the Birth-weight correlated with the Chemical Composition of the Milk of the Species

XXXV. The Total Dry Weight of a Crop of Aspergillus reared in the Absence and in the Presence of Various Quantities of Irritating Substances . . . . .

XXXVI. Interval elapsing before Germination when Spores of Penicillium are kept in Moist Chambers over Various Solutions of Sodium Chloride . . . .

XXXVII. Relation between the Humidity of the Soil and the Amount of Dry Substance produced . . . . .

XXXVIII. Relation between Concentration of the Solution and Germination of Peas . . . . . .

XXXIX. Relation of Regeneration of Nais to Strength of Solution

XL. Relation of Reproduction by Fission of Dero to the Strength of the Solution . . . . . .

XLI. Relative Size of Tadpoles reared in the Light and in the Dark . . . . . . . . . .

XLII. Average Dimensions of Tadpoles reared behind Clear and Colored Screens . . • • . . • .

XLIII. Percentage Deviations in Length of Larvæ of Strongylocentrotus reared behind Various Colored Screens, from Length of Larvæ reared in White Light . .

XLIV. Relative Time of Hatching of Organisms reared behind Colored Screens . . . . . . . .

XLV. The Optimum Intensity for Phototropism in Various Species of Plants . . . . . . .

XLVI. Minimum Intensity for Phototropic Response in Various Species of Plants . . . . . . .

XLVII. Average Total Increments in Length of the Plumules of Seedlings subjected to Different Temperatures . .

XLVIII. Average Increments in Length of the Radicles of Various Seedlingss subjected to Different Temperatures . .

XLIX. Time required for Spores of Penicillium to germinate, produce Visible Mycelium, and to form Spores, at Various Temperatures 
TABLE NO.

L. Critical Points for Various Plants . . . . . . 454

LI. The Absolute Increase in Length of Tadpoles at Different Temperatures . . . . . . . . . 457

LII. The Time Required for Various Species of Fish to hateh at Various Temperatures . . . . . . . . . 459

LIII. Critical Temperature Points for Various Animals . . 460

LIV. Average Weight and Percentage of Water in Plants reared at Various Temperatures . . . . • • • 461

LV. The Relation between the Temperature and the Sense of Thermotropic Response in Various Seedlings . . . 464

LVI. The Sense and the Average Extent of Thermotropis̀m at Different Temperatures . . . . . . . 465

LVII. Phototropic Limiting Angles for Various Plants . . 471 



\section{INDEX}

Acclimatization to solutions, 87; to heat and cold, 249,255, 257; to contact-irritation, 382 ; to stimuli, 484.

Acetic acid, attracts zoöspores, 38 ; repels amœba, 38 .

Acetoxim, 15.

Acids, inorganic, as poisons, 12 ; provoking response, 37 .

Acids, organic, as poisons, 13; chemotaxis towards, 37 .

Actinia, action of nicotin on, 23.

Actinophrys, action of hydrogen on, 5 ; of quinine, 27 ; of varying density, 76 ; heat-rigor of, 232 .

Actinospherium, response to density, 86 ; contact, 98,102 ; alternating current, 131 ; galvanic current, 139.

ADDuco, action of cocaine, 24.

Aderhold, chemotaxis, 33,34 ; gravity, 114 ; phototaxis, 183 ; acclimatization to cold, 257.

Adrlanowsky, light and seed germination, 420 ; green rays on plants, 435.

Aев , free nitrogen as food, 312.

Ethalium, rheotaxis of, 108 ; phototaxis, 185.

Affanasieff, cold on muscle, 242.

Agaricus, light on germination of, 420 .

Albertoni, cocaine on protoplasm, 24.

Alcohol, on protoplasm, 10 ; structural formulas, 11 ; resistance of organisms to, 11 ; chemotactic action, 37.

Aldehydes, 20.

Algæ, effect on, of hydrogen peroxide, 3 ; sodic-chromate, 4 ; potassic permanganate, 4 ; potassic chlorate, 4 ; potassic dichromate, 4 ; potassic arsenite and arsenate, 5; arsenious acid, 5 ; azoimid, 7 ; chloral hydrate, 10 ; carbonic disulphide, 12 ; organic acids, 13 ; calcic oxide, 13 ; diamid, phenylhydrazin, 16 ; nitrous acid, 21 ; paraldehyd, 21 ; sodic fluoride, 21 ; oxygen, 34 ; changing density, 86 ; molar agents, 100 ; growth of A. and salts, 302 ; nitrogen, 309 ; potassium, 318, 319 .

Alkaline salts and growth, 318 .

Alkaloids, as poisons, 22.

Ammonia, effect on Tradescantia and Spirogyra, 6.

Amœba, effect on, of hydrogen, 5 ; curare, 26 ; quinine, 27 ; chemotaxis, 38 ; varying density, 75,86 ; molar agents, 99 ; thigmotaxis, 105 ; electric irritation, 130,132 ; electric acclimatization, 139 ; electrotaxis, 148 ; phototaxis, 186; heat-rigor, 232 ; coagulation, 238 ; cold, 241 ; thermotaxis, 258 ; foods of A., 328 .

Ampelopsis, phototropism, 438.

Amphibia, foods of, 329 ; temperature and growth, 459.

Amphioxus, electric excitation, 137.

Ancylus, acclimatization to changed density, 85.

ANDrews, photic irritability of $\mathrm{Hy}-$ droids, 179.

Anex type of electric response, 137.

Animals, toxic protein compounds, 22 ; salts necessary for, 302; organic foods of, 327 ; thigmotropism, 382 ; geotropism, 398; phototropism, 442; growth of, at various temperatures, 457 .

Anisonema, change of structure with density of solution, 77 .

Annelida, negatively electrotactic, 147 ; ultramaximum, 234, 246.

Antimony, effect on growth, 314.

Antipyrin, on protoplasm, 27.

Ants, chemotaxis, 33 ; phototaxis, 198 ; thermotaxis, 261.

Apostrophe, conditions of, 190. 
Arstein, light on pelagic eggs, 417.

A pus, heat on growth of, 458 .

Area, acclimatization to changed density, 86.

Arennt, sulphur and growth, 314 .

Arsenic and growth, 314.

Arsenic acid, oxidization by, 5 .

Arsenious acid, oxidization by, 5 .

ArtaUd, temperature and metabolism, 222.

Arthropoda, effect of varying density, 81,82 ; salt absorption by, 88 ; positively electrotactic, 147.

Ascaridæ, strychnin, 26.

Ascaris, sodic carbonate, 13 ; sodic hydrate, 13 ; phenol, 19 ; hydrocyanic acid, 19.

Ascidia, thigmotropism, 382.

Asellus aquaticus, acclimatization to changing density, 86 .

Ash, of organisms, 295,296 ; of $\mathrm{dog}$ and dog's milk, 303.

Askenasy, latent period, 460.

Asparagin, chemotaxis towards, 38 .

Aspergillus, nitrogen food, 308.

Atmospheric pressure and growth, 368 ; electricity, 408.

Atropin and protoplasm, 24.

Azoimid, effect on protoplasm, 7 .

Bacilli, calcic oxide and caustic potash poisonous to, 13.

Bacillus ramosus, growth in colored light, 430 ; critical points, 454.

Bacteria, effect on, of oxygen, 2, 168 ; ozone, 3 ; potassic chlorate, 4 ; sodic chromate, 4 ; carbonic disulphide, 12 ; organic acids, 13 ; potassic carbonate, 13 ; salts of heavy metals, 14 ; diamid, 16 ; formaldehyde, 21 ; chemotactic, 33,45 ; towards oxygen, 34 ; inorganic salts, 36 ; alcohol and glycerine, 37 ; to determine isotonic coefficients, 74 ; acclimatization to density, 86 ; tonotaxis, 90 ; effect of violent shaking, 99, 371; of light, 169, 171, 174; dark-rigor, 175 ; change of light intensity, 178 ; light-rigor, 178 ; cold, 241 ; growth, 288 ; nitrifying, 299 , 308-312 ; food, 324,325 ; growth in light, 430 ; heat and growth, 452 ; critical temperatures, 454-457.
Bacterium termo, chemotaxis, 32, 38.

Balanus larvæ, chemotaxis, 198.

Baranetzk1, negative phototaxis, 185 ; response of Myxomycetes to light, 202 ; effect of pulling on growth, 372.

Bark extract, attracts Myxomycetes, 38.

Barnacles, respond to shadow, 179.

DE BARY, light and seed germination, 420.

Bases, effect on protoplasm, 13.

B̈̈ssler, nutrition of plants, 299.

Bastit, geotropism, 398.

BATEsox, geotropism, 397.

BAUDrmont, rôle of water in growth, 284.

BaUmaxs, iodine and growth, 367.

Bean, effect of changing density, 367 ; traumatropism, 384 .

BECLARD, colors and growth of fly, 432.

Beetles, geotaxis, 118.

Beggiatoa, negative phototaxis, 184 .

BenEcke, solutions for fungi, 302 ; potassium and growth, 318; rubidium and cæsium and growth, 320 ; magnesium and growth, 323 .

Benzenylamidoxim, poison, 15 .

Benzol derivatives, chemotaxis towards, 38.

Berva RD, chloroform on protoplasm, 9.

BEnT, effect of dense solutions on fish, $79,80,82$; acclimatization to density, 86 ; dark-rigor, 176 ; range of visible spectrum in animals, 203; effective rays in phototaxis, 203; oxygen and plants, 305; effective rays in plant growth, 428 ; green rays and growth, 435.

Berthelon, electricity and plant growth, 406.

Berthelot, nitrifying organisms, 308 ; enrichment of fallow ground, 310.

Beudanr, acclimatization to density, 85.

Beyerinck, food of Amœba, 328.

BEzold, water in animals, 58, 295.

Bialoblocki, heat and growth, 461.

Biedermans, electric response of muscle, 133.

Binz, theory of arsenical poisoning, 4,5 ; effects on protoplasm of halo- 
gens, 4 ; strychnin, 25 ; quinine, 26 ; acclimatization to arsenic, 28.

Birds, effect of temperature on growth, 459.

Bismuth, effect on growth, 314 .

Blasics, compression-rheostat, 127 ; electric irritation, 139 ; electrotaxis, 147-149.

Blood-corpuscles, to determine isotonic coefficients, 73 ; effect on, of density, 76 ; and molar agents, 99.

Blunt. See Downes.

Body, composition, 294.

BoER, gold chloride, 46.

Boкоrny, hydrogen peroxide a poison, 3 ; ammonia, 6 ; nutrition of plants, 299.

BONARDI, minimum temperature for bacteria, 241.

Borodiv, light and chloroplyyll arrangement, 187; light on spores, 424; effective rays in fern growth, 432 .

Boron, and growth, 314 .

TEN Bosch, quinine and protoplasm, 26.

Bourne, scorpions acclimated to own poison, 28.

Boussingault, free nitrogen as food, 310.

BraEs, heat and cold on statoblasts, 425.

Branchipus, heat and growth, 458 .

Brande, fluorine and growth, 317.

Brassica, light on growth, 428 .

BraUER, encystment, 256.

BREFELD, light and growth of toadstools, 420 .

Bromine, and protoplasm, 4; and growth, 316.

Brunchorst, electrotropism, 409-412.

Bryonia, light and growth, 419.

Bryozoa, desiccation of, 65 ; thigmotropism, 382.

BuchNer, toxic protein compounds, 22 ; chemotaxis, 33 ; light and bacteria, 172 ; movement and growth, 371.

Bufo lentiginosus, acclimatization to heat, 253; heat and growth, 457-460.

Buxge, iron and growth, 321-323.

Bü TSCHLI, encystment, 256.

Butyric acid, chemotaxis towards, 38 .

Buxton. See Ringer.
Cæsium and growth, 320.

Calcium and growth, 320 .

Caldani, frictional electricity and growth, 132.

Calliburces, heat and protoplasmic movement, 227.

Calmetre, immunization, 30 . See also EhrLich.

CAMPBEll, temperature and protoplasmic irritability, 230.

de Candolle, heat-rigor, 231 ; coldrigor, 240, 241.

Cannon, phototaxis of Daphnia, 203, 204.

Carbon, as food, 306; oxide of, and protoplasm, 6 .

Carbonic disulphide, and protoplasm, 12.

Carcinus, absorption of salt, 88 .

Cardium edule, acclimatization to density, 86.

Carnin, chemotaxis towards, 38 .

Cassis, acclimated to sulphuric acid, 28.

CAstre, acclimatization to contact, 108 ; to heat, 253.

Cat, light on growth of, 426.

Catalytic poison, action of, 7-9.

CELI, electrified air and plant growth, 408.

Cell-division and growth, 287.

Celli, food of Amœba, 328.

Certes, desiccation of Ciliata, 65 .

Chameleon, pigment response to light, 192.

Chara, and caustic potash, 13.

Charpentier, cocaine and protoplasm, 24.

Chastaign, oxidizing action of light, 162.

Chemical agents, effect on vital actions, 1 ; acclimatization to, 27 ; and growth, 293.

Chemotaxis, 32-54.

Chemotropism, 335 ; in insectivorous plants, 335 ; of roots, 336 ; of pollentubes, 337 ; of hyphæ, 340 ; of conjugation tubes of Spirogyra, 342 .

Chick, water in growth of, 286 ; electricity and growth of, 405 ; heat and growth, 459.

Chilomonas, phototaxis and photopathy, 183.

Chlamydomonas, thigmotaxis of, 106. 
Chloral hydrate, poison, 10.

Chlorine, poison, 4 ; effect on growth, 316.

Chloroform, action on protoplasm, 9, 10.

Chlorophyll, effect of light on position, 189 ; temperature and movements, 226 .

CMmolevitch, heat-rigor, 232.

Chodat, electricity and plants, 407.

Chromic acid, as poison, 3,4 .

Chytridium, phototaxis, 183.

Cienkowsin , phototaxis, 183.

Ciesielski, traumatropism, 384 ; geotropism, 393, 394 ; after-effect, 401 ; tropisin, 481.

Cilia, effect of density on movement, 77 ; electric stimulation, 145 ; temperature, 227.

Ciliata, effect on, of oxygen, 3 ; hydrogen peroxide, 3 ; chloroform and ether, 10 ; strychnin, 26 ; chemotaxis, 33 ; of saline lakes, 65 ; density effect, $76,78,86$; phototaxis, 187.

Clark, oxygen, 2.

Cobra poison, 30 .

Cocaine, effect on protoplasm, 24.

Cockroach, geotaxis, 118 ; thermotaxis, 261.

Colenterata, electric response, 137; phototaxis, 194.

Cons, phototaxis, 202 ; heat and protoplasm, 225.

Cold, 242 ; resistance to, 246 ; extreme, 248 ; acclimatization, 257.

Cold-rigor, 239.

Colored light, 432-436, 440, 441.

Crab, copper in blood of, 324 .

Critical temperatures, 460.

Crivelli, food of Amœba, 328.

Crustacea, density, 79, 81; optimum temperature, 458.

Cryptogams, water and growth, 350 ; geotropism, 378; thigmotropism, 381.

Cryptomonas, chemotaxis, 33.

Ctenophora, inorganic food, 303.

Cucurbita, moisture, 352.

Cukxoт, temperature and growth, 458.

Curare, Amœba, 26.

Cyphoderia, molar agents, 100 .

Cytotaxis, 52.

Czaper, phototropism, 471; tropism, $482,483$.
Czerxy, density, $75,76,78,86$.

Dallinger, heat and Infusoria, 252256.

Danilewsky, cocaine, 24; lecithin, 380.

Daphnia, phototaxis, 203-206.

DAREMBRAY, blood serum, 22.

Dark-rigor, 175, 176.

DARwIN, C., insectivorous plants, 99 ; chemotropism, 335 ; hydrotropism, 357; tendrils and twining, 377; thigmotropism, 379, 380, 383 ; traumatropism, 384-386; geotropism, 394; phototropism, 441, 485.

DARwin, F., moisture and growth, 252, geotropism, 397.

Davis, desiccation of rotifers, 62,63 .

DAY, nitrogen, 312.

Death, 1 ; by poisons, 2-24; desiccation, 60-65 ; density, 80-83 ; light, 171-175; heat, 231-249; limits, 275277.

Demsecke, gravity, 113.

Denerarn, temperature and secretion, 223.

DEмоOR, oxygen, 2,3 ; hydrogen, 5,6 ; ammonia, 6 ; oxides of carbon, 6 ; chloroform, 9 ; paraldehyde, 21; cold-rigor, 241.

Density of the medium, effect on protoplasm, 70-93; on growth, 362369.

Dermant, heat-rigor, 239.

Dero, fission and density, $365,366$.

Desiccation, protoplasm, 59 ; rigor and death, 60,61 ; acclimatization to, 65 .

Desnids, phototaxis, 183.

Detlefsen, hydrotropism, 257 ; traumatropism, 384.

Dewrtz, chemotaxis, 37; thigmotaxis, $106,107$.

Diamid, poison, 1, 16.

Diatoms, effect on, of chloral hydrate, 10 ; hydroxylamine, 15 ; ethylaldehyde, 21; phototaxis of, 184, 199; silicon food of, 324 .

Differential threshold stimulation, 43.

Difflugia, molar agents, 101.

Dionæa, response to contact, 99.

Dioscorea, light, 419.

Dodder, twining, 377, 484 .

DogIEL, curare, 26. 
Dogs, potassium and growth of, 319 .

Dolium, and sulphuric acid, 28.

Downes, analytic effect of light, 163 ; bactericidal effect of light, 171-173.

Doyk̀re, desiccation, 62 ; heat on Rotifera, 255.

Dragon-fly larvæ, electric stimulation, 137.

Draper, assimilation in plants, 166 .

Driesch, phototaxis, 202 ; growth, 282 ; geotropism, 400 ; phototropism, 443.

Drosera, organic acids, 13 ; thigmotaxis, 99 ; thigmotropism, 383, 481.

Drosophyllum, and contact, 99.

Dryness and protoplasm, 59, 60.

Drysdale, heat and protoplasm, 256.

Drisors, response to light, 207.

Duchartre, hydrotropism, 256.

Duclaux, chemical effect of light, 162, 163 ; election of food, 333.

Dutrochet, molar agents, 100 ; temperature on protoplasm, 225 ; acclimatization to heat, 252 ; twining, 377.

Duvalia, germination, 424 .

Earthworm, nicotin, 24; phototaxis, 203.

Echinodermata, nicotin, 24; density, 79 ; electric current, 137 ; phototaxis, 194 ; light on growth, 434 ; optimum temperature for growth, 458 .

Echinoids, strychnin, 26.

EDwards, light on growth, 425.

Effective rays in growth, 427-436; in phototropism, 440.

Egg, food materials in, 303 ; phosphorus, 313 ; iron, 322 ; electricity, 403.

Ehrenberg, heat, 251.

Ehrlich, ricin, 31 ; acclimatization to poison, 32.

Electricity, 126 ; protoplasm, 129-153; electrotaxis, 140-151; growth, 405414 ; electrotropism, 409-414.

Electrotaxis, 140-151.

Elfving, chloroform, 9 ; light, 174 ; gravity and growth, 391; geotropism, 398.

Embryos, phosphorus, 314 ; light, 417, 418.

Emery, salt absorption, 88.

Encystment, 256.
Engelmani, chemotaxis, 32,34 ; density, 86 ; electricity, $130,132,135$; bacteria and spectrum, 168; darkand light-rigor, 176, 178; changing light intensity, 179 ; phototaxis, 182 , $183,187,202,207$; retinal movements, 193 ; photopathy and chemical agents, 201 ; temperature, 227, 231.

Entomostraca, density, 81 .

Evtz, photopathy, 188.

Ephydra, acclimatization, 28.

Epistrophe, 190.

Epithelium, ciliated, 129, 227.

ERLACH, acclimatization, 29, 30.

ERrara, hydrotropism, 359; thigmotropism, 381 .

Eschenhagen, growth and density, 362.

Eschle, iodine and growth, 317.

Ether, 9, 10.

Ethylaldehyde, protoplasm, 21.

Euglena; chemotaxis, 33 ; phototaxis,

- 183 ; acclimatization to cold, 257 ; thermotaxis, 261.

EwaLD, electrotaxis, 147-150.

Excretion and poisons, 51.

Exver, pigment and light, 193.

Extent of medium and size, 473.

Fabre-Donergue, density, $76,86$.

Fallow ground, enrichment, 310 .

False, phototaxis, 181; traumatropism, 384 ; geotropism, 392 ; electrotropism, 409.

Famintzis, phototonus, 177 ; phototaxis, 182; chlorophyll position, 189 ; light and growth, 430.

Fatigati, rays which disturb metabolism, 170.

Fayrer, serpent poison, 28.

Fechner, threshold stimulation, 434.

Féré, temperature and chick's growth, 459.

Fick, electric stimulation, 133.

Figdor, phototropic limit, 439.

Fish, density-effects, 79-82 ; rheotaxis, 109 ; temperature and growth, 458, 459 ; medium and size, 474. See also Gold-fish.

Flagellata, chemotaxis, $33,36,45$; salt-absorption, 86,89 ; phototaxis, 182; acclimatization to heat, 252,255. 
Flammarion, effective rays in growth, 429.

Fly larvæ, chemotactic, 38 ; geotactic, 118.

Fluorine, and growth, 317.

Food, 309-330 ; response to, 39 ; election, 334.

Formaldehyde, poison, 20, 21.

Frank, chlorophyll position, 189 ; growth definition, 282 ; nitrogen as food, 308-310.

Franie. See Pfeiffer.

Franiland, light and bacteria, 171.

Frazeur, regeneration and density, 365.

FredA, electricity and growth, 408.

FredericQ, salt-absorption, 88 ; copper and growth, 324 .

Fresh water absorbed by marine organisms, 79,80 .

Fries, light and fungi, 420 .

Frog, sodic fluoride, 22 ; density, 82 ; salt-absorption, 88 ; electric stimulus, 132, 139; pigment and light, 192 ; water in developing, 285 ; size and medium, 474, 475 .

Frog's egg, cytotaxis, 52 ; cold-rigor, 240 ; oxygen and growth, 305 ; electricity, 405.

Fromans, soluble mineral bases as poisons, 13.

Fungi, salts of arsenic, 5 ; sulphurous oxide, 20 ; nitrous acids, 21 ; nutritive solutions, 302 ; hydrogen as food, 306 ; potassium, 318 ; iron, 323 ; organic foods, $324-326$; water and growth, 350; hydrotropism, 358; light and growth, 420 ; colored light, 430.

GAIN, water and growth, 254.

Galvanic current, acclimatization to, 139.

Gastropoda, copper in blood, 324.

Gautier, green rays and plants, 435.

Gavarret, desiccated rotifers, 62.

Geotaxis, 114-124.

Geotropism, 391-403 ; and phototropism, 470 .

Gerosa, cold, 241.

Germination, and solutions, 363 ; and light, 424 .

Gilbert. See Lawes.

GLAN, spectrophotometer, 160.
Glucose, reaction, 4 .

Glycerine, chemotactic, 37.

Gogorzs, density, 79-83; acclimatization, $86,87$.

Gold chloride, poison, $46,47$.

Gold-fish, density, 77, 79 .

Golubew, electricity stimulus, 130 .

Gorini, Amœba, 328.

Gotscilich, heat-rigor, 232, 293.

Graber, phototaxis, 203, 205，207 ; thermotaxis, 258, 261.

Grandeau, electricity, 406, 40 s.

Gravity, methods, 112 ; protoplasm, 113,114 ; direction of locomotion, 114-124; growth, 391-403.

Green plants, light, 174 ; organic food, $326,327$.

Greenwood, nicotin as poison, 24.

Groos, phototaxis and temperature, 200.

Growth, analysis of processes, 281 ; three factors, 282 ; regions in plants, 283 ; cell-division, 287 ; kinds of, 287 ; normal, 288, 289 ; chemical agents on, 293 ; as response to stimulus, 331 ; directed, 335, 355, 376, $384,387,391,409,437,460$; water, 350 ; density, 362 ; molar agents, 370 ; wounding, 384 ; gravity, 391 ; electricity, 405 ; light, 416 ; leat, 450 ; optimum, 454 ; maximum temperature, 456 ; range, 456 ; modification of rate, $478-480$; modification of direction, 480-483.

Gruber, density, 76 .

Haberland, chemotropism, 242.

Hæmoglobin, properties, 298.

HA LES, phototropism, 437.

HALLIBU RToN, heat-rigor, 239.

Halogens and growth, 315.

HAMBURGER, isotonic coefficient, 73 ; density, 76 .

HAMroND, light and growth, 426 .

Hansteen, organic food of plants, 327.

Hartig, phosphorus and growth, 314 .

Heat, absorption by plants, 170 ; nature of, 219 ; action on protoplasm, 222-263 ; chlorophyll formation, 224 ; irritability, 225 ; acclimatization to, 249, 251 ; extremes, 248 ; direction of locomotion, 258; growth, 450467 ; latent period, 460. 
Heat-rigor, 231, 239.

Hedgehog, hydrocyanic acid, 19.

Hegler, pulling and growth, 372, 374; electrotropism, 412.

Heidenschild, toxic proteids, 22.

Helianthus, pulling, 374 ; phototropism, 438 ; phototropic angle, 471.

Hellriegel, nitrogen fixation, 310 .

Hesmoltz, light on retina, 171.

Hen, mineral matter in egg, 303 ; fluorine, 317.

Hensen, light and pelagic eggs, 417 .

Hepatics, thigmotropism, 381 .

Heraus, nutrition, 300.

Herbivora, chlorine, 316.

Herbst, salts of marine animals, 303 ; phosphorus and growth, 314 ; sulphur, 315 ; chlorine, 316 ; potassium, 319 ; magnesium, 323.

Hermans, electrical measurements, 128 ; electric stimulation, 139 ; electrotaxis, 147-149; cold, 242.

НеrRıск, gravity and nucleus, 114 ; temperature and growth, 458.

Hertwig, O., growth of frogs, 458, 459.

Hertwig, $O$, and R., cocaine, 24; strychnin, 25 ; quinine, 26 ; chemotaxis, 33.

Hieronymus, chlorophyll movements, 191.

Higgenbottom, light and growth, 425.

Hiltwer, nitrogen and growth, 312.

Hofer, hydroxylamine, 15.

Hofminas, water and growth, 250; dryness and resistance to heat, 255 ; light and germination, 420, 424.

Hofmeister, molar agents and protoplasm, 100, 102; phototaxis, 184; temperature and protoplasm, 225; heat-rigor, 232 ; geotropism, 401.

Holothuroidea, geotaxis, 118.

Honey bee, temperature and metabolism, 223.

HoPpe-SEy Ler, acclimatization to heat, 251 ; lithium on growth, 318 ; magnesium, 323.

HoRva TH, shaking protoplasm, 99 ; bromine and growth, 316 ; rough movement on growth, 370.

Hudson, desiccation, 63.

Human embryo, water in growth, 286.

Humidity of soil and growth, 253.

HuXLEx, definition of growth, 282.
Hydra, nicotin, 23; density, 81, 86 ; phototaxis, 194, 202 ; light waves and growth, 430 .

Hydrachna, maximum temperature, 238.

Hydrazin and protoplasm, 16.

Hydric sulphide, protoplasm, 19, 20.

Hydrides, chemotactic, 37.

Hydrocyanic acid, poison, 19.

Hydrogen on protoplasm, 5 ; in organisms, 306 .

Hydrogen peroxide, poison, 3 .

Hydroidea, inorganic food, 303 ; iron, 323 ; density and regeneration, 364 ; thigmotropism, 382 ; geotropism, 398 , 399 ; phototropism, 443.

Hydroides dianthus, responds to shadow, 179.

Hydrotaxis, 66.

Hydrotropism, 255.

Hydroxylamine, poison, 1, 15.

Hyphæ, chemotropism, 340 ; hydrotropism, 358.

Hypochlorous acid, poison, 3, 4.

Hypozanthin, chemotactic stimulus, 38.

Indifferent chemical agents and protoplasm, 41, 42.

Induction apparatus, 127.

Infusoria, and potassic permanganate, 4 ; halogens, 4 ; arsenious acid salts, 5 ; azoimid, 7 ; chloral hydrate, 10 ; hydroxylamine, 15 ; phenylhydrazin, . 16; hydrocyanic acid, 19 ; ethylaldelyde, 21 ; quinine, 27 ; acclimatization, 28; chemotaxis, 33; thigmotaxis, 106 ; katex response, 137 ; electrotaxis, 140 ; wave-lengths which disturb metabolism, 170; heat and movement, 228 ; cold-rigor, 240 ; organic foods, 328; multiplication and light, 422.

Injurious substances, response to, 39 .

Inorganic salts and protoplasm, 37.

Insecta, hatching and temperature, 458 .

Insectivorous plants, chemotropism, 335.

Invertebrates, quinine, 26 ; sodic carbonate, 28 ; water in, 58 , 59 ; electric response, 136 ; electrotaxis, 147 ; ultramaximum temperatures, 234237; ultraminimum, 244-246; in hot 
springs, 250, 251; potassium as food, 318.

Iodine, protoplasm, 4 ; growth, 317.

Iron, and growth, 321-323.

Irritable period in development, 379; region in tendrils, 379 .

Isopoda, hydroxylamine, 15 ; formaldehyde, 21.

Isotonic coefficients, 23.

JACCARD, oxygen on plant growth, 305; pressure and growth, 368.

JANSE, salt-absorption, 88.

JARIUs, growth and density, 362.

Jensen, geotaxis, 114-118, 121-124.

JeNTxs, oxygen and growth, 305 ; density and growth, 362 .

Jounson, hydrotropism, 256 ; geotropism, 394.

Jösssox, rheotaxis, 108 ; rheotropism, 387; light and germination, 425.

JoRDAx, analysis of water, 301.

JUMELLE, water and growth, 253.

Karsten, light and plants, 419.

Katex type of electric response, 138.

KeLLER, retinal pigment and light, 192.

Krlebs, phototaxis, 183.

KLein, light fatal to fungi, 174.

Klinger, synthesis of organic compounds, 163.

KinıHT, hydrotropism in roots, 256; geotropism, 393.

KNowlton, temperature and growth, 459.

Kxy, light and growth, 423.

Косн, free nitrogen as algæ food, 309.

Kоснs, desiccation and seed vitality, 63,64 .

Kofoid, blastula cavity, 78, 79 .

Kossowitsch. See Косн.

Kraft, electricity on epithelium, 129.

liraus, light on growth, 420 ; green rays and growth, 430 .

Kreatin, chemotactic, 38.

KruKenberg, strychnin, 25 ; quinine, 26 ; water in organism, 58, 295; iron and growth, 321.

KüHN, desiccation of nematodes, 61 .

KÜHNE, effect on protoplasm of hydrogen, 5 ; chloroform, 9 ; veratrin, 24 ; varying density, $75-77$; electric current, 129, 132, 138, 139 ; tempera- ture and movement, 225 ; heat-rigor, 231,232 ; fatal temperature, 238 ; cold-rigor, 241 ; cold, 242, 247, 248. KUNKEL, iron as food, 323.

Lactic acid, chemotactic, 38.

Lamellibranchiata, electric stimulation, 132 ; light reaction, 179.

Lance, desiccation of tardigrades, 61 , 65.

Land animals, acquisition of oxygen, 304 ; sulphur, 314.

Larvæ, food, 323 ; light, 418.

LAURENT, nitrogen food of plants, 309 , 312.

LAwes, nitrogen as plant food, 310 ; food of mammals, 330 .

LEBER, chemotaxis, 33.

Le Dantec, thigmotaxis, 105, 107.

Leeches, poison, 15.

Legumes, enriching action of, 310 .

LeItGeB, light and spores, 424 .

Lemna, organic food of, 327.

Leмströм, electricity favors plant growth, 408.

LEONE, agitation of water and growth, 371.

LesAge, moisture and germination, $350,351$.

Leucocytes, oxygen and protoplasm, 3 ; chloroform, 10 ; quinine, 26 ; chemotaxis, 33 ; electric stimulation, 130.

Lewith, heat and coagulation, 255, 256.

Liebenberg, light and germination, 425.

Liebermany, water of organism, 58.

Liebscher, free nitrogen as plant food, 312.

Life, temperature-limits, 231.

Light, methods, 154 ; monochromatic, 156-158 ; physical properties of different wave-lengths, 158,159 ; intensity, 160 ; chemical action, 161165 ; thermic effect on metabolism, 166-170 ; chemical effect, 170, 171; vital limits, 171 ; and novement, 175 ; light-rigor, 178 ; and carbon dioxide production in plants, 179; phototaxis and photopathy, 180-210; of chlorophyll, 189 ; of pigment, 192 ; racial attunement, 197 ; period of life, 197, 198 ; mechanics of response 
to, $207-209$; retarding effect on growth, 416-423 ; accelerating effect, 423-427 ; phototropism, 436-445.

LiLLE, temperature and growth of tadpoles, 459.

Limax, geotaxis, 118-120.

Limnæa, poisoned by azoimid, 7 ; acclimatization to density, 85 ; light on growth of, 426 ; extent of medium and size, 474 .

Linum, light and growth, 428.

Lithium and growth, 318.

Lobster, copper in blood, 324 ; heat and growth, 458.

Locke, metallic salts as poisons, 14,15 .

Locomotion, interference with normal, 51 ; determination of direction, 32 , $66,89,105,114,140,180,258$.

Locust, heat and growth of, 458 .

LoEB, chemotaxis, 33 ; oxygen attracts fly larvæ, 38 ; gravity and invertebrates, 118 ; effect of light intensity, 179,197 ; phototaxis, 198 ; phototaxis and temperature, 200 ; light attunement, 200 ; plototaxis, 204, 206,208 ; temperature and irritability, 230 ; thermotaxis, $258-261$; rôle of water in growth, 304; oxygen and growth, 306 ; potassium and regeneration, 319 ; magnesium and growth, 323; growth and density, 364 ; contact and growth of stolons, 370 ; cutting and rate of growtl, 376 ; thigmotropism in hydroids, 382 ; rheotropism, 388 ; geotropism in hydroids, 399,400 ; phototropism in animals, 442, 443 .

Loew, effect on protoplasm of oxygen, 2 ; potassic chlorate, halogens and sodic chromate, 4 ; arsenical salts, 5 ; catalytic poisons, and azoimid, 7 ; sulphonal, 10 ; carbonic disulphide and inorganic acids, 12 ; soluble mineral bases, 13 ; salts of heavy metals, 14, 15 ; hydroxylamine, substitution poisons, 15 ; complex nitrogenous compounds, 16 ; hydrocyanic acid, 19 ; aldehydes, 20 ; ethylaldehydes, 21; sodic fluoride, 21,22 ; alkaloids, 22,23 ; acclimatization to poisons, 27 ; oxygen and growth, 294 ; phosphorus and growth, 314.
LOMBaRdini, effect of electricity on development of chick, 405.

Luввоск, chemotaxis, 33 ; effective wave-lengths in phototaxis, 203, 205.

LuDLOFF, electrotaxis, 141 ; theory of electrotaxis in Ciliata, 145.

MaCaire, heat and metabolism, 222.

MaCallum, iron in growth, 321.

MacDornele, light on frog's growth, 425.

- MaCDougaL, contact response of tendril, $378,379$.

McLeoD, electricity and plant growth, 407.

MAGGI, food of Amœba, 328.

Magnesium, and growth, 323 .

Magnetropism, 413.

Maize, silicon in, 324. See Zea.

Malic acid, chemotactic, 37, 38 .

Mammals, quinine, 27 ; foods of, 330.

Man, acclimatization to poisons, 28; sulphur as food, 315.

Manganese, and growth, 321.

Manganic acid, poison, 3,4 .

Marine organisms, effect of fresh water on, 79 ; foods of, 303.

Marmier, immunity, 30.

Marshale, phototaxis, 194.

Martin Saint-Ange, rêle of water in growth, 284.

Massart, effect on protoplasm of paraldehyde and formaldehyde, 21; cocaine, 24 ; antipyrin, 27 ; chemotaxis, 33,34 ; isotonic coefficients, 73,74 ; density and protoplasmic structure, $\mathbf{7 6}, 80$; acclimatization to density, 86-88; tonotaxis, 89-92 ; phosphorescence, 98 ; thigmotaxis, 106, 107 ; gravity and Protista, 114116, 121 ; phototaxis, 200.

Matthias. See Hermann.

Mavpas, light and growth of Infusoria, 422 .

MAYER, absorption of heat by plants, 170 ; temperature and metabolism, 222.

Mechanics of response, 45.

Meltzer, shaking bacteria, 99, 371 .

Mendelssohy, change of optimum, 254 ; thermotaxis, 258, 259.

Metabolism, modification by poisons, $1-27$; by dryness, 59 ; molar agents, 
98 ; by light, 166-175 ; by heat, 222225 ; limiting conditions of, 275.

Metscinilof ria, 33.

Mice, acclimatized to ricin, 29-32.

MigULA, inorganic acids on protoplasm, 12.

MiLDe, light and spores, 424.

Mixot, growth, 289.

Mistletoe, light and growth, 423, 438.

Mryoshi, chemotropism, 338, 340 ; hydrotropism, 358.

Mont, twining stems, 377 ; acclimatization to light, 444 .

Morssan, temperature and metabolism in plants, 228 .

Moist gelatine, no thigmotropic response to, 278 .

Moisture and protoplasm, 58.

Molar agents, and lifeless matter, 97 ; and protoplasm, 97 ; movement, 98, 99; metabolism, 98; direction of locomotion, 105 ; and growth, 370.

Molds, and sodic carbonate, 28 ; mutritive solutions for, 302 ; and free nitrogen, 308 ; potassium and growth, 318 ; rubidium, 320 ; election of organic foods, 333 ; thigmotropism, 381 ; electrotropism, 412 ; light, 420.

Molecular composition and effect on metabolism, 39 .

Moleschotт, effect of light on vertebrates, 422 .

Molisch, hydrotropism, 257 ; potassium and calcium in growth, 319, 320 ; chemotropism, 336, 337 ; hydrotropism, 359 ; thigmotropism, 381.

Mollusca, formaldehyde, 21 ; quinine, 27 ; changed density, 79 ; electrotaxis, 147; phototaxis, 202, 207 ; ultramaximum temperature, 235; ultraminimum, 245; species living in hot springs, 251; composition, 295 ; light and growth, 426.

Montegazza, effect of strong light on bacteria, 171.

Monti, food of Amoba, 328.

Moore, light and chlorophyll arrangement, 189, 191, 192.

Moriggia, heat-rigor, 232.

Morphine, and protoplasm, 25.

Moths, phototaxis, 197.
Mucor, phenylhydrazin a poison, 16 ; tropisms in, 482.

MüLLER, H., responding region in phototropism, 441.

Muller, N. J.C., definition of growth, 282.

Müller, O., thigmotropism, 379, 380.

Muller-Hettlingen, electric stress in seedlings, 405; electrotropism, 409.

Müller-Thurgau, freezing-point in plants, 247.

MüNTER, vitality of dried seeds, 64 .

Mü NTz, nitrifying organisms, 308, 310.

Musca, light and growth, 432. See also Fly.

Muscle, electric stimulus, 133, 135 ; cold-effect, 242.

Myriapoda, hydrocyanic acid secreted, 19.

Mytilus, acclimatization to density, 85, 86.

Myxomycetes, hydrogen, 5 ; chemotaxis, 33, 38, 45; varying density, 75,86 ; molar agents, 100 ; electric stimulation, 129; light stimulus, 179 ; phototaxis, 184, 202.

NAGEL, electric stimulus, 135-138; electrotaxis in invertebrates, 146, 150,151 ; light stimulus, 179 ; mechanics of light respoinse, 207.

NÄGELI, catalytic poisons, 7 ; salts of metals as poisons, 14 ; phototaxis, 182 ; temperature and movement, 225 ; cold-rigor, 241 ; nutritive solution for fungi, 302; cæsium and growth, 320 .

Nais, regeneration and solutions, 365 . Naja tripudians, acclimatization to poison of, 30 .

Natica, acclimated to sulphuric acid, 28.

NeAL, corrosive sublimates as poison, 15 ; acclimatization to poison, 30,31 .

Nematoda, azoimid, 7 ; chloral hydrate, 10 ; desiccation, 61 .

Nencki, chlorine and growth, 316 ; sodium and growth, 318.

Nephelis, effect of varying density, 81 .

Nereis, effect of cocaine, 24.

Nerve, electric stimulation, 133, 135.

Nicotin, and protoplasm, 23, 24. 
Niepce de Saint Victor, chemical action of light on starch, 165.

Nikolsk1, curare and protoplasm, 26.

Nitella, cold-rigor, 241.

Nitrogen, source of, in organisms, 307 ; free N. as food, 308,313 .

Nitrogenous compounds, as poisons, 16-21; chemotactic, 38.

Nitrous acids, and protoplasm, 21.

Noвbe, free nitrogen as plant food, 312 ; potassium as food, 319 .

Noctiluca, effect of paraldehycle, 21; formaldehyde, 21; antipyrin, 27; deformation, 98 .

Nuclein, composition, 298.

Nutritive solutions, for algæ, 302 ; for fungi, 302 ; light and seed germination, 420 .

Nutritive values, laws of, 325 .

OGata, food of Infusoria, 328.

OHLMïLler, ozone and bacteriá, 3.

Oltuanss, phototaxis, 183, 205, 206.

Osmus, penetrability of tissues by light, 165.

Optimum, 40 ; change of, 254 ; concentration for growth, 364 ; movement for growth, 372 ; temperature for growth, 454-456, 460, 461.

Orbitolites, molar agents, 100 ; thigmotaxis, 106 ; thigmotropism, 376.

Organic, compounds chemotactic, 37 ; food used in growth, 324; food, election of, 333 .

Organisms, atomic composition of dry substance, 296 ; elements important for, 297,298 ; food of non-chlorophyllaceous O., 299.

Oscillaria, phototaxis, 184.

Osmosis, rôle in organic life, 71 ; quantitative measure of, 71-73.

Osmotic index, 82.

Ostracoda, azoimid, 7.

Ostrea, acclimatization to changed density, 85.

OSTWALD, temperature and osmosis, 83 ; electrical methods, 126.

Overton, chemotropism, 242.

Oxygen, effect on anærobic bacteria, 2 ; on protoplasm, $2-5$; antipyrin, 27 ; chemotactic, 34 ; thigmotactic, 106 ; as food, 304 ; and growth, 305.

Ozone, and bacteria, 3.
Palæmon, nicotin, 24.

PaLM, cause of twining, 377.

Paludina, changing density, 85.

Paneth, hydrogen peroxide and Ciliata, 3.

Paraldehyde, protoplasm, 21.

Paramecium, strychnin, 26 ; electrotaxis, 142, 144, 145; change of optimum, 254; thermotaxis, 259, 260.

Parasites, oxygen, 2.

PARKer, response of pigment to light, 193.

Pasteur, ultramaximum of dry spores, 255.

Patella, acclimated to diminished temperature, 85 .

Pathogenic bacteria, chemotaxis, 33 .

Perrce, twining in dodder, 377.

Pelias berus, rabbits acclimated to poison of, 30.

Pelomyxa, electric stimulus, 129,133 , 134.

Penicillium, fixes free nitrogen, 308.

Peptone, chemotactic, 38.

Peranema, electric response, 130.

Perceptive region, in phototropism, 441.

Perkiss, gravity and Limax, 118-120.

Permanganic acid, poison, 3, 4 .

Peronospora, does not germinate in light, 420.

Petermans, free nitrogen as plant. food, 312 .

Pfeffer, chemotaxis, 33, 36- 45 ; measure of osmosis, 71 ; tonotaxis, 89,90 ; thigmotaxis, 106,108 ; wavelength active in assimilation, 166 ; growth, 281 ; election of food, 333 ; chemotropism, 337 ; method of isolating the root tip, 395 ; cause of twining, 377 ; irritable period in thigmotaxis, 379 ; contact stimulus, $382,383,386$.

Pfeiffer, free nitrogen and plants, 312.

Phanerogamia, free nitrogen as food, 312 ; potassium, 318 ; calcium, 320 ; electrotropism, 411 ; red rays and growth, 436.

Phenol, as poison, 18.

Phenylhydrazin, poison, 16.

Phosphorescence, 98. 
Phosphorus, and growth, 313.

Photopathy, 180 ; distribution, 182 ; laws of, 196 ; and chemical constitution of medium, 201.

Phototaxis, 180, 195; true and false, 181 ; distribution, 182 ; effect on $\mathrm{P}$. of strong light, 196 ; laws of, 196 ; effective rays, 201; P. vs. photopathy, 203.

Phototonus, 177.

Phototropism, 437, 438 ; optimum intensity in, 439 ; effective rays, 443 ; mechanics of, 444 ; limiting angle, 471, 472 ; after-effect, 484.

Phycomyces, water and spores, 358; heat and growth, 464.

Pick Fond, heat-rigor, 231.

Pictet, cold-rigor, 240.

Pigeon, acclimatization to poison, 29.

Pigs, food of growing, 330.

Planaria, azoimid, 7 ; hydroxylamine, 15 ; density, 81 ; thigmotaxis, 105 ; photopathy, 206.

Planorbis, azoimid, 7 ; density, 85.

Plastic foods, 293.

Plateau, density, 80-82, 86 ; absorption of salt, 88.

Platt, geotaxis, 124.

Poa, light on seeds, 424.

Poisons, oxidizing, 3, 49 ; catalytic, 7, 50 ; salt-forming, 12,50 ; substitution, 15, 50; acclimatization to, 29.

Poleck, silicon in hen's egg, 324.

Pollen-tubes, chemotropism, 337, 338 ; hydrotropism, 358.

Polygordius, phototaxis, 200.

Polyphemus, density effect, 76 .

Polystoma, salt-absorption in, 89.

Polystomella, electric stimulus, 129.

Polytrichum, light and germination, 424.

Porthesia, thermotaxis, 261.

Potassium, growth, 318 ; regeneration, 319.

Potassium salts, poisons, 4, 5 .

Poucher, light-stimulus, 179.

Preissia, light and germination, 424.

Presch, sulphur and growth, 315.

Preyer, anabiosis, 61, 63.

Pringshein, light on green plants, 174 ; light-rigor, 178.

Propionic acid, 38.

Prösher, growth of mammals, 330, 331 .
Protein poison compounds, 22.

Protista, cocaine, 24; morphine, 25 ; desiccation, 64 ; contact response, 99 ; geotaxis, 114, 115, 118, 121-123; electric stimulus, 134; acclimatization to electricity, 139 ; electrotaxis, 146 ; photopathy and phototaxis, 182, 203 ; heat, 224, 228 ; thermotaxis, 258,261 ; growth of $P$. and light, 416.

Protoplasin, hydroxylamine, 1 ; oxygen, 2,3 ; substitution poisons, 15 ; nicotin, 23 ; strychnin, 25 ; quinine, 26 ; antipylin, 27 ; acclimatization to poisons, 32 ; specific resistance of, 49 ; structure of, 70 ; varying density, 74 ; acclimatization to change of density, 86 ; contact, 97 ; periodic disturbances, 98 ; electric stimulus, 138; temperature, 241 ; chemical agents and growth, 274; structure and composition, 274,275 ; structural limiting conditions, 276.

Pseudophototaxis, 181, 182.

Pugh, free nitrogen, 310.

Pulmonates, fresh-water, varying density, 78.

Purnewitsch, free nitrogen, 308.

Purkinje, cold, 241.

Pyrocatechin, poison, 19.

Quincke, effect of blue rays on growth, 436.

Quinine on protoplasm, 26, 27.

Rabbit, acclimatization to snake poisons, 30 .

RACIBorsiri, growth and density, 363.

Radiant heat and growth, 463 .

Radiolaria and silicon, 324.

RAILlet, desiccation-rigor, 61 .

Rana, heat and growth, 457-459.

Radber, oxygen on frog's eggs, 305 ; temperature and growth, 459.

Ravlin, phosphorus and growth, 314.

$R_{A Y}$, gravity and growth, 391.

RAYleIGH, monochromatic light, 158.

Regeneration and potassium, 319; density, 364, 365.

Reinhardt, chemotropism, 340.

Reinke, light and plant assimilation, 167; moisture and growth, 251; agitation of water and growth, 371 . 
Removal of tissue, and growth, 375 .

Repulsion, by chemical agents, 38 ; by dense solutions, 91.

Resistance capacity, to poisons, 48 ; to dense solutions, 83 ; to heat, 249.

Resorcin, poison, 19.

Response to injurious substances, 39 ; mechanies of R., 45,$277 ; 480-484$.

Rheostat, 127.

Rheotaxis, 105-108.

Rheotropism, 387, 388.

Rhizoids, hydrotropism of, 257.

Rhizoma, geotropism, 398.

Rhizopoda, thigmotaxis, 106 ; electric stimulus, 129 ; phototaxis, 185 ; thermotaxis, 259.

Richards, E. See Jordan.

Richards, H. M., growth and chemical irritation, 332.

Richet, toxic dose and temperature, 2.

Rrснтек, varying clensity, $78,80,86$, 89; geotropism, 398.

Rigor, cold-R., 242; dark-R., 175; desiccation-R., 61; heat-R., 281; light-R., 178.

Rivger, density, 80.

Rischawi, temperature and excretion, 223 ; electrotropism, 410.

Roemer, chemotaxis, 33.

Roos, iodine and growth, 317 .

Roots, chemotropism, 336 ; hydrotropism, 256 ; thigmotropism, 380 ; geotropism, 393.

Rosanoff, chemotaxis, 108.

Rossвach, 24; strychnin, 25, 26; quinine, 26 ; varying density, 78 ; heat and excretion, 224; heat and cilia movement, 228 .

Rотн, temperature and cilia movement, 227.

Rothert, transmission of light stimulus, 441.

Rotifera, chloral hydrate, 10; hydroxylamine, 15 ; desiccation-rigor, 61, 62 ; cold-rigor, 240; heat and dryness, 255.

Rough movements and growth, 370 .

Roux, cytotropism, 52, 53.

Rubidium, effect on growth, 320 .

Rusconi, electricity on frog's egg, 405.

Russeld, movements and growth, 371.

SACrs, penetration of light into plant tissue, 165 ; active rays in plant assimilation, 166 ; false phototaxis, 181 ; temperature and protoplasmic movement, 225 ; hydrotropism, 256 ; growth, 281; silicon and growth, 324; hydrotropism, 358; thigmotropism, 380, 383 ; geotropism, 393397,402 ; light and growth, $41 \overline{7}, 418$; curve of growth, 421 ; effective rays in growth, 428 .

Salmo trutta, light on eggs of, 426 .

Salts as poisons, 14, 15; chemotactic, 36 .

SAnkow $r$, heat-rigor, 232.

SARGeNT, fission and density, 365, 366.

Schizomycetes, pseudotaxis, 182.

Schenck, effect of twisting on plant growth, 375.

SchlösIng, nitrifying organism, 308, 310 ; algæ and nitrogen, $309 ;$ free nitrogen and phanerogams, 312.

Scmuankewitsch, changed density on Flagellata, $76,77,86$.

Schuid, movements and growth, 371.

Schyitz, light and growth, 420.

Schneider, iron and growth, 321.

SCHNETzLER, rays affecting growth of tadpoles, 432, 435.

Scholtz, pulling on plant growth, 372.

Schoumow-Srmanowsky. See Nencku.

Schroder, strychnin, 26.

Schultze, M., strychnin, 25 ; temperature and protoplasmic movement, 225 ; heat-rigor, 232.

Schultze, O., temperature and growth, 459.

Schulz, salts of arsenic, 4,5 ; acclimatization to poison, 28 ; poisons and cell activity, 332 .

SсnёruaYer, chloroform and ether, 10 ; cocaine, 24 ; strychnin, 25, 26 ; antipyrin, 27 ; heat and cilia movements, 228 ; cold-rigor, 240.

SCHÜ TZENBERGER, dry protoplasm resists heat, 255.

Schḯnz, gravity and Protista, 114116,121 ; temperature and irritability, 230 ; acclimatization to cold, 257 ; gravity and growth, 391.

SCHWEIzER, compression rheostat, 127 ; electric current, 139; electrotaxis, 147-149.

Scyllium, effect of changed solution on, 80 . 
Sea-urchin, inorganic food, 303.

Secretion, contact stimulus, 99.

Seed, vitality, 64; phosphorus in, 303 ; light on germination, 419,422 .

Seedling, oxygen and growth, 305 ; ether and growth, 333 ; pulling stimulus, 372, 373; rheotropism, 387 ; electricity and growth, 405-410.

Selenous oxide and Spirogyra, 20.

SEMPER, extent of medium on size of snails and fish, 474 .

Sensitive plant, light on growth, 429 ; temperature and growth, 458 .

Sepolia, nicotin, 24.

Serpula uncinata, sudden change of intensity, 179.

Serpulidæ, phototropism, 442.

SEWALL, acclimatization to poison, 29.

Sexual cells, cocaine, 24 ; quinine, 26.

Sheep, food of growing, 330.

SHUTTLEWorT́, acclimatization to cold, 257.

Silkworm, cold-rigor in eggs, 240.

Silicon and growth, 324.

Sinapis, phototropic, 438.

Slug, thigmotaxis, 105.

Snails, strychnin, 26 ; extent of medium on size, 474,475 .

Socis, iron and growth, 323 .

Sodium, salts on protoplasm, 4, 21, 22 ; and growth, 318.

Solutions, physical action of, 70 .

Soroкis, phototonus, 177.

Spallaxzani, desiccation-rigor in rotifers, 61, 6:3.

Spauldivg, false and true thigmotropism, 38t, 385.

Specific rate of vibration, 98 .

Spectrophor, Reinke's, 156.

Spectrophotometer, 160.

Spermatozoa, chemotaxis, 37 ; thigmotaxis, 106, 107.

Spermatozoids, chemotaxis, 33.

Spirillum, chemotaxis, 33 .

Spirographis, sudden change of light, 179.

Spirogyra, ammonia, 6 ; salts of heavy metals, 14; selenous oxide, 20 ; formaldehyde, 21; phosphorus on growth of, 314 ; effective rays in growth, 430.

Sponge, silicon and growth, 324 .

Sponge gemmules, 65 .
Spores, desiccation of, 65 ; heat, 256 ; chemotropism, 341 ; light and germination, $419,422,424$; heat and germination, 452.

Squid, copper in blood of, 324 .

Stall, chemotaxis, $33,38,45$; hydrotaxis, 66 ; acclimatization to changed lensity, 86 ; tonotaxis, 89 ; rheotaxis, 108 ; light and chlorophyll arrangement, 181, 191; phototaxis, 183185 ; thermotaxis, 250.

Stameroff, light and growth, 420.

Stanife. See Klinger.

Stange, chemotaxis, 33-38; growth and density, 362 .

Starfish, geotaxis, 118 ; phototaxis, 202 ; inorganic food and growth, 303.

Statoblasts, changing temperature necessary to development of, 425 .

Stebler, light and germination, 424.

Stefanowska, light response of pigment, 193.

Steinach, direct action of light on iris movenients, 179 ; light response of pigment, 192 .

Stems, hydrotropism, 358 ; gravity on growth, 397 ; curvature, 398 ; daylight and growth, 419.

Stentor, salts as poisons, 15 ; acclimatization, 30,31 ; photopathy, 189 ; thigmotropism, 375.

Stimulus, relation between intensity and response, 39, 40.

Stoklasa, free nitrogen and plants, 312.

Stolons, geotropism, 400 ; phototropism, 44:3.

Strasburger, rheotaxis, 108; lightresponse, 179 ; phototaxis, 183,184 , 199, 202, 208; light and temperature on locomotion, 199 ; temperature and irritability, 230 ; high temperature, 239 ; acclimatization to cold, 257 ; chemotropism, 337.

Strongylus rufescens, desiccation-rigor, 61.

Strontium, growth, 321.

Structure of protoplasm, 70.

Strychnin, 25, 26.

Sugar, attracts Bacterium termo, 37.

Sulphonal, 10.

Sulphur, on growth, 314 ; oxide and growth, 20. 
Swarm spores, protoplasm, 10 ; phototaxis, 182, 18:3.

Szczawinska, light response of pigment, 193.

Tadpoles, salts of arsenic, 5 ; of heavy metals, 14 ; varying density, 86; geotaxis, 124; electrotaxis, 149 ; growth and density, 367 ; light and growth, 425, 426, 432, 433; extent of medium and size, 475,478 .

Tammans, fluorine and growth, 317 .

Tannic acid, chemotaxis, 38 .

TAPpenner, fluorine and growth, 317.

Tardigrades, desiccation, 61, 65; drying and heat resistance, 255.

Tartaric acid, chemotactic, 38.

Taurin, chemotactic, 38.

Temperature, effect on toxic dose, 2 ; increases osmosis, 83 ; 'T. and metabolism, 222, 223; and protoplasmic activity, 229, 230 ; ultromaximum, 231, 234-237; ultraminimum, 239 ; sudden change of, 460,461 ; thermotropism, 464.

Temporary rigor, 242.

Tendrils, twining, 377.

Tension, effect on plasma, 374 .

Tetraspora, and density, 78, 89.

Thalassicola, contact-response, 98, 99.

Thermogenic food, 293.

Thermotaxis, 105, 258, 261.

Thigmotropism, $376,383,463,465$, 466.

Thouvenin, electricity and plants, 409 .

Threshold stimulus to chemical agents, 42.

TumirizefF, plant assimilation and wave-lengths, 167, 169.

Toloner, magnetropism, 413.

Tonotaxis, 89-91.

Tradescantia hairs, oxygen, 2,3 ; hydrogen, 5; ammonia, 6 ; chloroform, 9 ; molar agents, 102 ; electric current, 132 ; colcl-rigor, 241, 242 ; cold, 247.

Traumatropism, 384, 386.

Tremblex, phototaxis, 194.

Treviranus, temperature and metabolism, 223.

Trew, light and growth, 421.

Triton, electric stimulation, 187 ; thermotaxis, 261.
Tritonium and sulphuric acid, 28.

Trophotaxis, 39.

Tropism, 484,

Trout, light and growth, 426 .

True, traumatropism, 384; electrotropism, 410.

Tschaplowitz, moisture and growth, 253.

Tsuramoto, alcohols, 10-12.

Tubers, light and growth, 418 .

Tubifex, poisons, 14 .

Tubularia, oxygen and regeneration, 306 ; potassium and regeneration, 319.

Tusas, molar agents and growth, 371 .

Tunicates, inorganic food of, 303.

Turbo, acclimatization to changed density, 56 .

Twining stems, 376.

Ulothrix, prototaxis of spores, 199.

Ultramaximum temperature, 234.

Ultraminimum temperature, 244.

Urea, attractive, 38.

Urostyla, thigmotaxis, 106.

VAlentin, cold, 241.

Valeric acid, chemical response, 38.

Vallisneria, cold-rigor, 241.

VANDEVELDE, germination and concentration, 363.

DE VARIGNY, varying density, 80 ; acclimatization to density, 85, 86 ; extent of medium and size of Limnæa, $475-478$.

Veltes, cold-rigor, 241 ; temperature and chlorophyll movements, 226, 227.

Veratrin, poison, 24.

Vernon, temperature and growth of Echinoidea, 458.

Vertebrates, chemicals, 25 ; electrotaxis, 150 ; potassium on growth, 318 ; calcium as food, 321 ; organic foods of, 384 .

Verworn, chemotaxis, 33, 34 ; acclimatization to changed density, 86; phosphorescence, 98, 99; molar agents, 100 ; thigmotaxis, 106 ; geotaxis, 121-123; electrical apparatus, 126; electric stimulation, 129-131, 134, 137 ; acclimatization to electric current, 139, 140 ; electrotaxis, 141, 
146, 148 ; phototaxis, $183-185,188$, 199, 202 ; growth, 282 ; thermotaxis, $258,259$.

Vicia, phototropism, 438.

Vierordt, spectrophotometer, 160.

Villox, green rays and light, 435.

Vinegar eel, organic acids, 13 ; acclimated to sodic carbonate, 28.

Vixes, temperature and metabolism, 222 ; freezing point for plants, 247 ; growth, 282 ; potassinm and growth, 318 ; light and growth, $420,421,423$; effective rays in growth, 430 .

Vitis, phototropism, 438.

Volvox, phototaxis, 183 ; light attunement, 206.

DE TrIEs, quantitative studies in osmosis, 71-73; salt-absorption, 88; growth and density, 362 ; contact stimulus, 382 ; thigmotropism, 383.

WAChTEL, geotropism, 394.

W ALLER, electric response, 128 ; electrotaxis, 147.

WARD, bactericidal effect of strong light, 171-174; cell division and growth, 287; light and growth, 421.

WARREN, electric current on plant growth, 407.

WAsud ax, thermotaxis, 261.

Water, amonnt in organisms, 58 ; rôle in organisms, 59 ; effect on protoplasm, 67 ; analysis of, 301 ; effect on growth, 360 .

Water animals, hydrazin a poison, 16 ; source of oxygen for, 304 .

WEBER, phosphorus and growth, 314 .

WEeBer's law, 43-45, 440.

WetTstein, light on development, 174.

WEYL, heat-rigor, 239.

WHIPPLE, light accelerating growth, 423.

Wieler, oxygen and plant growth, 305 ; growth and density, 362.

Wiesser, hydrotropism, 257 ; trallmatropism, 384, 385 ; light and seedlings, 417; mistletoe, 423; Vicia faba, 429 ; intensity of light and response, 438; effective rays for seedlings, 440 ; heat and spore germination, 452 ; phototropism and geotropism, 471.

DE WILDEMANN, thermotaxis, 258, 261. WiLfarti, enriching action of legumes, 310.

WulLem, light response, 207.

Wilson, phototropism of Hydra, 202.

WINDLE, electricity and development of chick, 405 .

Winogradosiry, phototaxis, 184; nutrition of bacteria, 299 ; sulphur and bacteria, 315 ; rubidium and growth, 320; hydrogen clisulphide and bacteria, 326 .

WOLFF, silicon and growth, 324 .

v. WoLkof , temperature on metabolism, 222.

WolLNy, atmospheric electricity, 408.

Woltering, iron and growth, 323.

Worms, formaldehyde, 21 ; electrotaxis, 147 ; phototaxis, 195 ; ultramaximum, 285 ; ultraminimum, 245; acclimatization to high temperatures, 251.

Wortmans, chemotropism, 340 ; hydrotropism, 358, 360; thigmotropism, 381 ; geotropism, 402.

Wounding, and traumatropism, 384.

Yeast, phosphorus and growth, 313; potassium and growth, 318 .

YUNG, acclimatization to changed density. 86 ; food of Amphibia, 329, 330 ; density and growth, 367; light and growth, 425, 426; light and growth of hydra, 430 ; different wave-lengths on growth of tadpoles, 433-435; extent of medium and size of tadpoles, 475.

Zacharias, varying density on protoplasm, 76 .

Zea, silicon and growth, 324; phototropism, 438 ; temperature and growth, 451-455; thermotropism, 463-465.

Zoöspores, chemotaxis, $34,36,37$. 


\section{ERRATA AND ADDENDA}

PAGE

10, note, Elfing should read Elfving.

21, last sentence in next to last paragraph, should read: "On this account even neutral nitrites kill such plants as have an acid cèll-sap, but not such as have a neutral cell-sap (some algæ, e.g. Spirogyra)."

35. See the valuable paper of H. S. Jennings, Jour. of Physiology, XXI, 258-322, 1897, where it is shown that carbon dioxide in weak solutions is attractive; in strong solutions, repellent.

59 , line $3,81.9 \%$ water should be $71.9 \%$; line $4,71.1 \%$ water should be $74.1 \%$.

61. See WrLL, Centralbl. f. Bakteriol. (2), III, 17; latent life of yeast.

72, second note, next to-last line, one-tenth of should read ten times.

SS, second line from bottom, Frederic should read FredericQ.

10s, fifth line from bottom, Jönssox should read Jönsson.

113, line 9, should read, "cannot be affected, as a whole, by gravity."

127 , fourth line from the bottom, electrometer should read electrodynamometer.

146, line 13, galvanotaxis should read electrotaxis.

157, Table XVII. Other solutions are suggested by IVresser, '79, Wien. Denkschrift, XXXIX, 187.

160. For measurement of chemical intensity see Wresser, '93. Sitzungsber. Wien. Akad. CII, 298.

170 , line 5, over should read under.

174, line 13, Elving should read Elfving; so, too, on p. 213.

191, description of Fig. 56, line 1, spaces should be species.

196, first paragraph. Dr. A. D. Mead informs me that at Wood's Holl Diastylus swims free at night so that it is taken in the tow. Consequently these crustaceans are not exclusively mud-inhabiting, and may constitute no exception to the rule.

209, first two lines should read, "migrated in travelling $18 \mathrm{~cm}$. in full light, $15 \%$ faster than the same individual migrated in light $\frac{1}{4}$ as strong."

224. A fuller table than that of Rischawi is given by Clausex, 'S9, Landw. Jahrbuicher, XIX, 907, 911.

230. Compare with Camplell's table the similar results of EDwards, Studies Biol. Lab., Johns Hopkins Univ., July, 1887; and those of Huxt, '97, Science, V, 907.

247, line 15, dele words "between Bombyx."

251. Trustworthy observations on organisms in hot springs have lately been made by DAvis, Science, July 30, 1897, and Setchell, University (of California) Chronicle, I, 110-119. 



\title{
EXPERIMENTAL MORPHOLOGY.
}

BY

\author{
CHARLES BENEDICT DAVENPORT, Ph.D.,
}

Instructor in Zoölogy in Harvard University.

PART I.

\section{EFFECT OF CHEMICAL AND PHYSICAL AGENTS UPON PROTOPLASM.}

8vo. Cloth. Price $\$ 2.60$, net.

It is intended to serve as an introduction and guide to the study and development of the individual regarded as a complex of processes rather than a mere succession of different forms. It brings together under appropriate heads the published observations hitherto made on the subject, laying special stress upon the results and methods of those investigations which have a quantitative value. The central idea of the work is that ontogeny is a series of reactions to chemical and physical agents. This determines the scope of the work, and the division of the effects of agents under the heads : I. Protoplasmic Movements; II. Growth; III. Cell Division; IV. Differentiation.

"The thoroughness which characterizes this important treatise renders it the most useful annotated bibliography of the subject which has appeared. But it is far more than an expanded bibliography. With a good sense of proportion, Dr. Davenport has placed at the command of biologists, not merely the results which have already been secured in this fascinating field, but he has pointed out certain directions which new investigations ought to pursue if they are to be fruitful. The sequence of subjects does not commend itself to us as in all respects the best, for it appears as if the effect of molar agents and of varying moisture upon protoplasm might well precede instead of follow the action of chemical agents and the molecular forces, but, aside from this, one can go with the author along a straight path, until he comes to the end of this part now before us; namely, the action of light and heat upon protoplasm. The general considerations of the effects of chemical and physical agents upon protoplasm, which constitute the closing chapter of this part, are carefully stated, and kept on relatively safe ground; they are at the same time of a distinctly suggestive character, which must aid in carrying out the chief wish of the author; namely, the stimulation of further inquiries in this attractive and fertile field. Botanists owe to Dr. Davenport very sincere thanks for the exhaustive manner in which he has presented the botanical side of his subject." - American Fournal of Science.

"The material which is discussed has been well digested and is well arranged, and the style is on the whole clear and concise. The book is a readable one, and the descriptions and criticisms employed in experimentation, and the bibliographical lists at the conclusion of each chapter, contribute materially to the value the book possesses for both the morphologist and the physiologist." - Science.

\section{THE MACMILLAN COMPANY,}






